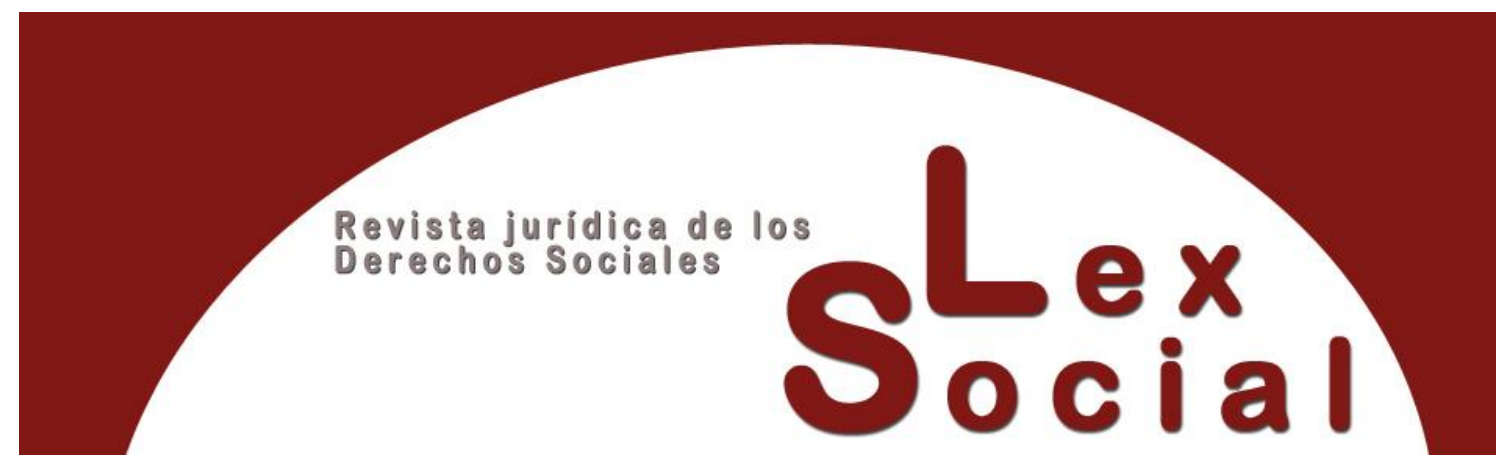

\title{
DE LAS DECLARACIONES A LA GARANTÍA MULTINIVEL DE LOS DERECHOS SOCIALES FUNDAMENTALES: LA APORTACIÓN DE GEORGES GURVITCH
}

\section{FROM DECLARATIONS TO THE MULTILEVEL GUARANTEE OF FUNDAMENTAL SOCIAL RIGHTS: THE CONTRIBUTION OF GEORGES GURVITCH}

\author{
JOSÉ LUIS MONEREO PÉREZ \\ Catedrático de Derecho del Trabajo y Seguridad Social \\ Universidad de Granada \\ https://orcid.org/0000-0002-0230-6615
}

Cómo citar este trabajo: Monereo Pérez, J.L (2022). De las declaraciones a la garantía multinivel de los derechos sociales fundamentales: la aportación de Georges Gurvitch. Lex Social, Revista De Derechos Sociales 12 (1), pp. 166273. https://doi.org/10.46661/lexsocial.6323

\section{RESUMEN}

Georges Gurvitch (1894-1965) es uno de los fundadores de la sociología del Derecho en Europa y, desde luego, del Derecho Social tal y como hoy lo conocemos, aunque es necesario destacar también su condición eminente de filósofo y jurista interdisciplinar. Hay que llamar la atención sobre el dato histórico innegable de que su concepción de los derechos sociales se reflejó en diversas obras y en particular en su propuesta de La Déclaration des Droits Sociaux (1944), tuvieron una influencia extraordinaria en diversos instrumentos internacionales como la Declaración de los Derechos Humanos de 1948, el Pacto de Derechos Económicos, Sociales y Culturales de 1966, la Carta Social Europea (tanto en la versión originaria de 18 de octubre de 1961 como en la versión revisada de 1996), la Carta de los Derechos Sociales Fundamentales de los Trabajadores de 1989

\section{$($ (c) ) EY-NC-SA}


(Declaración de Política del Derecho), y la Carta de los Derechos Fundamentales de la Unión Europea (versión originaria el 18 de diciembre de 2000 como Declaración de Política del Derecho, y la versión definitiva de 2007 con rango específico de Tratado de la Unión Europea, conforme a lo establecido en el art. 6.1 del Tratado de la Unión Europea, en redacción dada ya en su momento por el Tratado de Lisboa). Esa influencia se hace extensible a su magistral obra mayor en el campo fundante de la Idea Social y del propio Derecho Social, a saber: La Idea del derecho social (1932).

Palabras Clave: Estado Social de Derecho, soberanía, pluralismo social y político, democracia social, declaraciones de los derechos sociales fundamentales, cartas europeas de derechos fundamentales, democracia económica e industrial, sindicatos, Derecho social, socialismo democrático.

\begin{abstract}
Georges Gurvitch (1894-1965) is one of the founders of the sociology of Law in Europe and, of course, of Social Law as we know it today, although it is also necessary to highlight his eminent condition as an interdisciplinary philosopher and jurist. Attention must be drawn to the undeniable historical fact that his conception of social rights was reflected in various works and in particular in his proposal for La Déclaration des Droits Sociaux (1944), they had an extraordinary influence on various international instruments such as the Declaration of Human Rights of 1948, the Covenant of Economic, Social and Cultural Rights of 1966, the European Social Charter (both in the original version of October 18, 1961 and in the revised version of 1996), the Charter of Social Rights Fundamentals of Workers of 1989 (Declaration of Law Policy), and the Charter of Fundamental Rights of the European Union (original version on December 18, 2000 as Declaration of Law Policy, and the definitive version of 2007 with specific rank of the Treaty of the European Union, in accordance with the provisions of article 6.1 of the Treaty of the European Union, in wording already given at the time by the Traffic do of Lisbon). This influence extends to his masterful major work in the founding field of the Social Idea and Social Law itself, namely: The Idea of Social Law (1932).
\end{abstract}

KeYwords: Law Social State, Sovereignty, Social and Political Pluralism, Social Democracy, declarations fundamental social rights, European charters of fundamental rights Economic and Industrial Democracy, Trade Unions, Social Law, Democratic Socialism. 


\section{LA CONCEPCIÓN PLURALISTA DEL DERECHO: PERSPECTIVAS FILOSÓFICA Y} SOCIOLÓGICA.

1. Supuestos filosóficos, sociológicos y jurídicos generales.

2. Pensamiento social: Los grupos sociales y su Derecho autónomo.

3. El modelo de pluralismo jurídico democrático de Gurvitch y su confrontación con otros paradigmas pluralistas.

3.1. Pluralismo social versus pluralismo jurídico.

3.2. El sistema pluralista del Derecho en Gurvitch.

3.2.1. Fundamentación.

3.2.2. Rechazo de la reducción del Derecho al "Derecho estatal".

3.2.3. La defensa incondicionada del pluralismo jurídico y de la existencia de un "Derecho social" de carácter extraestatal.

3.2.4. La teoría pluralista del Derecho en la sociedad contemporánea.

3.2.5. Pluralismo, derecho social y pensamiento social de la Iglesia.

II. LA IDEA DEL DERECHO SOCIAL: EL SISTEMA DE DERECHO SOCIAL.

III. DERECHO SOCIAL Y SOCIEDAD DEMOCRÁTICA: EL DERECHO SOCIAL EN LA CONSTITUCIÓN DEL TRABAJO Y DE LA DEMOCRACIA PARTICIPATIVA.

1. En general.

2. El principio democrático y la idea del Derecho social.

IV. BIBLIOGRAFÍA.

IV. 1. Obras seleccionadas de Georges Gurvitch y traducciones al español.

IV. 2. Sobre Georges Gurvitch y su época. 
"El desarrollo social del derecho, y esto es lo grande e impresionante de él, no se presenta como la realización de un programa, sino como autorrealización de una necesidad histórica supraconsciente, que ya estaba alli antes de ser

reconocida, la que es más fuerte que toda resistencia y más consciente de sus metas que todos los malentendidos del hombre aislado. La marcha inconfundible e irresistible de este proceso ha de hacer honor y llenar de profunda satisfacción a aquellos que anhelan, con corazón ardiente, lo que se muestra ya a la distancia: la meta de una constitución social, más justa que no conozca ya a señores ni a súbditos del trabajo, sino sólo a ciudadanos trabajadores"

GUSTAV RADBRUCH1

\section{LA CONCEPCIÓN PLURALISTA DEL DERECHO: PERSPECTIVAS FILOSÓFICA Y SOCIOLÓGICA}

\section{Supuestos filosóficos, sociológicos y jurídicos generales}

Georges Gurvitch (1894-1965) es uno de los fundadores de la sociología del Derecho en Europa y, desde luego, del Derecho Social tal y como hoy lo conocemos2, aunque es necesario destacar también su condición eminente de filósofo y jurista interdisciplinar. Es de origen ruso (nació en Noworossisk el 2 de noviembre de 1894), se nacionalizó francés (adoptó la nacionalidad francesa en 1928), falleciendo en París en 1965. Fue Doctor en Derecho de la Universidad de Petrogrado (1917). En la elaboración de su pensamiento tiene un papel crucial su experiencia personal en el desarrollo de la Revolución Rusa y en la enseñanza en las Universidades de Petrogrado-Leningrado y de Tomsk, dictando clases de Derecho Público en la Universidad de Petrogrado (1919-1920). Fue Profesor Asociado también en la Universidad de Praga (Sección Rusa; años 1921-1924), para después establecerse en Francia, en las Universidades de Estrasburgo y en la Sorbona de París, donde mantuvo una actividad continuada con la excepción de los años de la segunda guerra mundial, en que tuvo que exiliarse, residiendo en los Estados Unidos. Doctor en Letras, en

1 RADBRUCH, G.: "Del derecho individualista al derecho social", en RADBRUCH, G.: El Hombre en el Derecho. Conferencias y artículos seleccionados sobre cuestiones fundamentales del Derecho, trad. Aníbal del Campo, revisión, edición y estudio preliminar a cargo de J.L. Monereo Pérez, Granada, Comares (Col. Crítica del Derecho), 2020, pág. 24.

2En este sentido TREVES, R.: "Sociologia del diritto oggi e crisis dello Stato sociale", en Sociologia del diritto, núms.2-3 (1986), págs.247 y sigs., en particular págs.247 y 255, quien lo coloca al efecto explícitamente junto a Weber y Geiger. Igualmente, TOULEMONT, R.: Sociologie et pluralisme dialectique. Introduction à l'oeuvre de Georges Gurvitch, Louvain-París, ed.Nauwelaerts, 1955; TANZI, A.: Georges Gurvitch. Il progetto della libertà, Pisa, Pacini, 1980, especialmente el capítulo I. TANZI, A.: Democrazia e Sistema pluralista in G. Gurvitch, Siena, Circolo Giuridico dell' Università, 1974; STAFANI, M.A.: G. Gurvitch sociologo del diritto, Assisi-Roma, Carucci, 1974; D’ AQUANNDO, M.: Gurvitch pluralista, Napoli, Milano, Morano, 1974; BALANDIER, G.: Gurvitch, París, PUF, 1972; MONEREO PÉREZ, J.L.: Pluralismo jurídico y Derecho social: La sociología del Derecho de Gurvitch, Estudio Preliminar a la obra de GURVITCH, G.: Elementos de sociología jurídica, Granada, Editorial Comares (Col. Crítica del Derecho), 2001, págs. XIIICXLVI; y la monografía más completa y actualizada, MONEREO PÉREZ, J.L.: Democracia pluralista y Derecho Social. La teoría crítica de Georges Gurvitch, Barcelona, Ediciones de Intervención Cultural/El Viejo Topo, 2021. 
la Soborna (1932). Fue Profesor Agregado de Sociología en la Universidad de Burdeos (1934-1935) y Profesor de Sociología en la Universidad de Estrasburgo, Francia (1935). En los Estados Unidos enseñó como Profesor Asociado de Sociología en la "New School of Social Sciences de Nueva York" (1940-1943), recibiendo la influencia de la "jurisprudencia sociológica" y de la sociología jurídica norteamericana3. Director del Instituto Sociológico Francés, École Libre des Hautes Etudes, Nueva York (1942) y Profesor Investigador en la Universidad de Harvard, Sección sociológica (1944-1945). En los Estados Unidos, asumió el cargo de Redactor-Jefe del Journal of Legal and Political Sociology, 1942-1947, 7 volúmenes, International University Press, Nueva York. Fue también Secretario General del Instituto Internacional de Sociología del Derecho (París, 1931-1940), y editor de Archives de philosophie du Droit et de Sociologie Juridique (París, 1931-1940). En 1948 es nombrado profesor de la Sorbona. Gurvitch fue el fundador del Centro de estudios sociológicos y de los prestigiosos Cahiers internationaux de sociologie $e^{4}$.

Pero es un pensador que se enorgullecía de haber ido "contra-corriente" en su trayectoria intelectual: "Para terminar, séame permitido indicar que la suerte ha querido que, en mi reflexión y en mi esfuerzo, yo fuera, a menudo, "contra la corriente". El ritmo de mi pensamiento casi nunca ha encajado con el que estaba de moda. Soy, por tanto, un "excluido de la horda", digamos que por vocación. En su mayoría, los sociólogos franceses y americanos me consideran como un "filósofo" que se equivocó de puerta; y los "filósofos" me miran como un "traidor" que ha cambiado de campo. Sin embargo, esta situación de aislamiento, a veces penosa, me parece muy natural. Mi toma de posición implica la necesidad de una íntima colaboración no sólo entre teoría e investigación empírica, sino también entre sociología y filosofía, renunciando ambas a su dogmatismo y a su imperialismo. Vigilándose y criticándose mutuamente pueden y deben, aun guardando su completa autonomía, plantearse entre ellas cuestiones de fondo a las que solamente su inquietante vis-a-vis es capaz de responder... Sólo cuando esta forma de ver -que intenté precisar en mi artículo Sociología y Filosofía, escrito para la Enciclopedia Francesa, vol.19, 1957- sea aceptada, espero dejar de ser proscrito por ambos clanes"5.

3Resulta significativo, en tal sentido, el prefacio de Roscoe Pound, a su libro Sociology of Law, New York, Philosophical Library and Alliance Book Corporation, 1942 (ed. inglesa: London, Kegan Paul, 1947). Pero también que Gurvitch incorporase un importante estudio de Roscoe Pound a su monografía sobre la sociología del siglo XX. Véase POUND, R.: "Sociología y jurisprudencia", en GURVITCH, G.y MOORE, W.E. (Dir.): Sociología del siglo XX, t.I., Barcelona, Ed. El Ateneo, 1970, págs.271 y sigs. Véase POUND, R.: Las grandes tendencias del pensamiento jurídico, traducción y estudio preliminar por José Puig Brutau, edición al cuidado de José Luis Monereo Pérez, Granada, Comares (Col. Crítica del Derecho), 2004; POUND, R.: Evolución de la libertad. El desarrollo de las garantías constitucionales de la libertad, edición y estudio preliminar, "La "jurisprudencia sociológica" de Roscoe Pound: la teoría del derecho como ingeniería social” (pp. IX-LXXXIII), a cargo de José Luis Monereo Pérez, Granada, Ed.Comares (Col. Crítica del Derecho), 2004.

4 Para una exposición más amplia sobre la biografía de Gurvitch, véase, por todos, BALANDIER, G.: Gurvitch, París, P.U.F., 1972. Es muy ilustrativa al respecto la propia autobiografía intelectual de GURVITCH, G.: "Mon itinéraire intellectuel uo l' exclu de la horde", en L' Homme et la sociéte, I, 1996, págs. 3 a 12; ya publicado antes en Les Lettres nouvelles, núm. 62 (1958).

5 Cfr. GURVITCH, G.: "Mon itinéraire intellectuel ou l' exclu de la horde", en Lettres Nouvelles, núm.6 (1958), págs.65 a 83. Publicado después en L'Homme et la Société, I, 1966; y en la recopilación de 
Esta breve indicación biográfica pone de manifiesto un rasgo sencillamente fundamental en la vida y en el pensamiento crítico de Georges Gurvitch: la larga experiencia cosmopolita, la asunción de un talante decididamente tolerante y, significativamente, la lógica pluralista abierta tanto en el plano político y jurídico como en el cultural e ideológico. Y es que su contacto estrecho con diversas culturas políticas y jurídicas acabó de reafirmarle en el ideal del pluralismo democrático que siempre defendió, en contraposición (y en lucha tenaz) a toda tentación totalitaria respecto de la organización político-jurídica de la sociedad y en cuanto a postular la necesidad de una generosa colaboración interdisciplinar en el campo de las ciencias sociales. La figura de Gurvitch es extraordinaria y su aportación al pluralismo jurídico y al Derecho Social ha sido determinante en términos doctrinales, pero también en términos de positivación de los derechos humanos en verdaderos derechos fundamentales. La figura de Gurvitch es extraordinaria relevante por su aportación al pluralismo jurídico y al Derecho Social. Dicha aportación ha sido determinante en términos de construcción de sus fundamentos doctrinales, pero también en términos de positivación de los derechos humanos proclamados en verdaderos derechos fundamentales. Fue un gran pensador, pero también un gran luchador por la implantación del Derecho Social en nuestro tiempo.

En una primera fase de la evolución de su pensamiento Gurvitch centró preferentemente su actividad en la Filosofía del Derecho, aunque siempre desde una perspectiva interdisciplinar. Seguidamente, haciendo valer sus inagotables inquietudes intelectuales, en una segunda etapa -a partir de la postguerra- se interesó especialmente en la sociología Derecho y, después, en los últimos años ante todo centró sus reflexiones en el campo de la sociología general, sin perder, no obstante, atención a la sociología jurídica, aunque esta pasó decididamente a un segundo plano en esta segunda fase en favor de su amplia dedicación a la sociología general6. Para Gurvitch la sociología del Derecho es ante todo sociología del espíritu, junto con la filosofía jurídica. Esta afirmación originaria (más tarde, como se verá después, matizará su decisión) del entronque común de ambas disciplinas (sociología y filosofía jurídica) no supuso, sin embargo, nunca una confusión entre ambas. La esfera de lo espiritual es percibida desde perspectivas diversas, a saber: la sociología, en función de la realidad social; por su parte, la filosofía jurídica centraría su atención en dicha esfera espiritual desde una manera directa e intrínseca, considerándola en sí misma. Por lo demás, para Gurvitch es estrictamente necesaria la colaboración entre la filosofía jurídica y la sociología del Derecho como condición para captar toda la riqueza de la experiencia jurídica. Es necesario destacar que esa experiencia jurídica muestra, según Gurvitch, un carácter dramático por la existencia de una profusa red de antinomias y conflictos derivados del pluralismo social y jurídico (entendiéndose éste como la coexistencia en el tiempo y en un mismo espacio territorial de dos o más sistemas jurídicos vigentes). Hace referencia a una

DELEDALLE, G. y HUISMAN, D.: Les philosophes français d'aujourd' hui pas eux-mêmes. Autobiografhie de la philosophie française contemporaine, París, C.D.U., 1963, págs.100 a 116; igualmente recogido en DUVIGNAUD, J.: Georges Gurvitch, París, Éditions Seghers, 1969, págs.79 a 98.

6Véase infra. No obstante para comprobar el persistente interés por la sociología del Derecho, puede desde ahora tenerse en cuenta sobre todo su estudio sobre los "Problèmes de sociologie du Droit", en GURVITCH, G. (Dir.): Traité de sociologie, t.II., $4^{\mathrm{a}}$ ed., París, PUF, 1962, págs. 173 a 206. Estudio publicado pocos años ante de su muerte (1965). 
experiencia jurídica integral de lo inmediato que abarca tanto la experiencia de lo espiritual como la de lo sensible. La experiencia jurídica inmediata se inserta dentro de aquélla experiencia plena, siendo extraordinariamente variable. Dicha experiencia jurídica inmediata está constituida por actos colectivos de reconocimiento de las situaciones sociales perceptibles que realizan los valores jurídicos fundamentales. La experiencia jurídica muestra una gran variedad, la cual está determinada por la misma variedad de las formas de sociabilidad7, del medio ambiente y de las condiciones culturales e históricas8. De ahí la defensa -impuesta por la observación de la realidad jurídica- del pluralismo jurídico, que se vincula a la riqueza de la experiencia humana y la multiplicidad de fuentes de producción jurídica.

En efecto, Gurvitch pondrá de relieve que existen dos modos de creación del Derecho: el propio del "Derecho individual" (producto del Derecho estatal y de la autonomía privada individual) y el que corresponde al "Derecho social" (expresión formal del poder9 de los grupos sociales para autorreglamentar sus propios intereses e incorporar sus propias tradiciones culturales). Éste último se genera en los grupos que vertebran la sociedad civil (formas espontáneas de relación social), los cuales dan vida a reglas, originadas en hechos

7Véase GURVITCH, G.: "Remarques sur les formes de sociabilité", en Archives de Philosophie du droit et de sociologie juridique, núms.3-4 (1935), págs.43 a 91.

8Esa idea de la variabilidad de la experiencia enlaza con el pensamiento del pragmatismo de JAMES, W.: Pragmatismo.Un nиevo nombre para algunos antiguos modos de pensar (1907), Barcelona, Eds.Orbis, 1975.

9Sobre el "poder organizado", véanse las reflexiones de LUHMANN, N.: Poder (1979), Barcelona, Ed.Anthropos, 1995, caps. VIII y IX, págs.127 y sigs., y 137 y sigs. Es así que en el pensamiento de Guvitch subyace la idea de que el Derecho social formaliza las relaciones entre los grupos sociales. Se trata de una formalización ("forma") de la realidad social ("vida"; "mundo de la vida"). Esta diferenciación entre forma y vida, entre el desarrollo de los grupos sociales y los procesos de regulación y organización jurídica y política de los mismos, remite no sólo al pensamiento de Simmel sino también, aunque más matizadamente, al sistema de pensamiento de Habermas (Derecho procedimental y democracia participativa) y Teubner (Derecho reflexivo). Direcciones doctrinales en las que se enfatiza precisamente los condicionantes de la regulación y organización jurídica ("forma") por la mutiplicidad y heterogeneidad de los componentes de la vida social ("vida", "factividad"). En esa vinculación está una de las llaves maestras del sistema democrático; y para Gurvitch, el Derecho social autónomo de los grupos facilita de modo más inmediato y participativo el enlace entre "vida" y "formas" de regulación (modelo de regulación jurídica). Véase SIMMEL, G.: Individuo y libertad, Barcelona, Ed. Crítica, 1986); SIMMEL, G.: Filosofía del Dinero, traducción e Introducción de Ramón García Cotarelo, edición al cuidado de J.L. Monereo Pérez, Granada, Ed. Comares (Col. Crítica del Derecho), 2003; HABERMAS, J.: Facticidad y validez, Madrid, Ed. Trotta, 1998; TEUBNER, G.: Le droit, un système autopoiétique, París, PUF, 1993. Existe también una nítida vinculación entre el pensamiento de Tönnies y del de Gurvitch, reflejada especialmente en la importancia que ambos atribuyen al Derecho producido y difunido en las relaciones sociales y en la aceptación de una visión pluralista y conflictual en el campo social (pluralismo social), que se proyecta en el ámbito de lo jurídico (pluralismo jurídico). La forma jurídica expresa el conflicto mismo, lo categoriza y conforma, y lo asimila desde la normatividad específica hacia una solución institucionazada. Puede consultarse, al respecto, FAVRETTO, A.R.: "Dal pluralismo dei rapporti social al pluralismo delle normatività. Indiduo e Diritto in Tönnies e Gurvitch”, en Sociologia del diritto, núm. 33 (1992), págs. 55 a 76. Respecto al pensamiento de Tönnies, véase TÖNNIES, F.: Comunidad y asociación, trad. José-Francisco Ivars, revisión técnica de J.L. Monereo Pérez, edición y estudio preliminar, "La interpretación de la Modernidad en Tönnies: "Comunidad" y "Sociedad-Asociación" en el desarrollo histórico" (pp. XI-XLIV), a cargo de J. L. Monereo Pérez, Granada, Ed. Comares (Col. Crítica del Derecho), 2009, págs. 9 y sigs.; TÖNNIES, F.: Principios de sociología, trad. Vicente Lloréns, revisión, edición y estudio preliminar, "La sociología como crítica social: la aportación de Ferdinand Tönnies" (pp. XV-XLVI), a cargo de J.L. Monereo Pérez, Granada, Ed. Comares (Col. Crítica del Derecho), Granada, 2009. 
que adquieren naturaleza normativa ("hechos normativos" generadores de reglas jurídicas, sirviendo de fuente primaria o material de Derecho). Es una forma de Derecho que emana de la forma de sociabilidad por integración o interpenetración, siendo así que el Derecho no tiene un único poder jurídico, sino una serie de poderes sociales con facultad normativa creadora. Para él, el Derecho en el marco del pluralismo jurídico y en cada uno de sus espacios dotados de un ámbito de autonomía tiene la funcionalidad de mantener el orden social de cada grupo a través de la aplicación de reglas o normas jurídicas y la resolución de conflictos o controversias jurídicas. Para Gurvitch la coexistencia de múltiples ordenamientos legales y múltiples órdenes o cuerpos de reglas son hechos sociales. El pluralismo jurídico jurídico, por otra parte, no es una realidad histórica precisamente nueva, pues está presente a lo largo de las grandes etapas históricas 10.

Gurvitch defiende un pluralismo jurídico cuyos órdenes normativos reflejan constelaciones diversas en las formas de agregación social. Y esto sirve también para los complejos e internamente diferenciados campos jurídicos globales (incluida la hoy fortalecida "lex mercatoria"). Pero en un contexto nada idílico, pues en las sociedades complejas del capitalismo avanzado preside un modo de sociabilidad caracterizado por la competencia generalizada que tiende a destruir los factores que conducen a la solidaridad y a hacer comunidad. Contribuye a que se viva en una sociedad más injusta y con aumento de las desigualdades sociales. No es sólo la crisis del Estado distribuidor en una sociedad asegurada -en la que no confiaba demasiado Gurvitch por su temor al totalitarismo de la homogeneidad y porque pensaba la sociedad en términos de igualdad plural entre los grupos colectivos-, sino también la crisis del mismo pluralismo jurídico-social que se ve literalmente en peligro de destrucción por un tipo de globalización neoliberal, que Gurvitch no pudo ver en vida.

Hay crisis de las soberanías estatales y de las soberanías derivadas de los fenómenos colectivos de grupo. Las tendencias en este proceso avanzado de mundialización y de exaltación de la competencia desenfrenada tienden a deslegitimar la solidaridad, las teorías de la justicia redistributiva y el pluralismo social y jurídico. Tiende a desacreditar el sentido de comunidad que ha formado parte inescindible de las Declaraciones de Derechos y del constitucionalismo democrático-social con Estado Social de Derecho y basado en el pluralismo social y político. En cierta medida la globalización ha producido una desorganización de las categorías establecidas en la modernidad, incidiendo sobre el sentido y alcance de la soberanía del Estado nacional como elemento central de la organización del espacio político y marco de referencia de la convivencia humana. Se produce un desequilibrio interno entre la autoridad del Estado y los actores sociales y económicos, y, a la vez, un marcado desequilibrio externo entre la soberanía del Estado y la emergencia de

10 En la perspectiva histórica, BERMAN, H.J.: Law and Revolution: The Formation o Western Legal Tradition, Cambridge, Harvard University Press, 1983; y su traducción al español, BERMAN, H.J.: La formación de la tradición jurídica de Occidente, trad. M. Utrilla de Neira, México D.F., FCE, 1996; y asimismo la revisión de conjunto hecha por HOOKER, B.: Legal Pluralism, Oxford, Clarendon PressOxford University Press, 1975. Igualmente, ARNAUD, A.-J.: Entre modernidad y globalización. Siete lecciones de filosofía del Derecho y del Estado (1998), trad. N. González Lajoie, Universidad Externado de Colombia, 2000. 
otros poderes que no controla (salvo las grandes potencias mundiales que tienen una mayor capacidad de decisión en los grandes espacios). Es así que la globalización acelera el proceso -ya antes iniciado- de disgregación de la política moderna, toda vez que la acción política no puede quedar confinada al espacio territorial del Estado nacional, poniendo de manifiesto -con mayor intensidad- que Estado y Política (y espacio de lo político) han dejado de coincidir en términos significativos, porque se han incrementado los poderes extraterritoriales. Estamos en un nuevo sistema mundial en una "situación de excepción" permanente, con una globalización neoliberal, que pone en cuestión el constitucionalismo social europeo ante los nuevos poderes soberanos y biopolíticos11. En este sentido, propuestas como las de Gurvitch de potenciación de los fenómenos de organización colectiva y de autogobierno tendrían que ser repensados para conferir nuevas dimensiones a las estructuras comunitarias que conjuguen universalismo y particularismo y, al propio tiempo, pueden hacer frente y defenderse de los poderes biopolíticos del mercado y del ejercicio por las grandes constelaciones de las potencias mundiales. Para ello será necesario no sólo fortalecer las estructuras democráticas de los Estados, sino también crear estructuras geopolíticas transnacionales que puedan operar con eficacia en los grandes espacios políticos y económicos del nuevo orden mundial. Entonces la ciudadanía debe ser más que nunca tanto una ciudadanía de los derechos como una ciudadanía de los poderes colectivos 12. Desde este punto de vista ciudadanía social y dignidad humana van unidas inescindiblemente en la lucha por los derechos fundamentales13.

En realidad, podría aceptar Gurvitch la idea de que el Derecho social autónomo propiamente dicho surge de los fenómenos colectivos de grupo y no simplemente de los fenómenos de agregado social, ya que éstos remiten al hecho de que una multiplicidad de personas se comporta del mismo modo; mientras que en los fenómenos colectivos de grupo el proceso colectivo que se genera produce una modificación de la interacción de los sujetos que de él forman parte, así como de su solidaridad14. De este modo en la colectividad en grupo los

11 Véase, ampliamente, MONEREO PÉREZ, J.L.: La organización jurídico-económica del capitalismo moderno: El Derecho de la Economía, estudio preliminar a RIPERT, G.: Aspectos jurídicos del capitalismo moderno, trad. J. Quero Morales, revisión, edición y estudio preliminar a cargo de J. L. Monereo Pérez, Granada, Ed. Comares, (Col. Crítica del Derecho), 2001, págs. XIII-CL; MONEREO PÉREZ, J.L.: Espacio de lo político y orden internacional. La teoría política de Carl Schmitt, Barcelona, Ediciones de Intervención Cultural/El Viejo Topo, 2015, espec., págs. 460 y sigs., y la bibliografía allí citada.; MONEREO PÉREZ, J.L.: Soberanía y orden internacional en Carl Schmitt, estudio preliminar a SCHMITT, C.: El nomos de la tierra en el Derecho de Gentes del "Ius publicum europaeum", trad. D. Schilling Thou, revisión, edición y estudio preliminar a cargo de J.L. Monereo Pérez, Granada, Ed. Comares (Col. Crítica del Derecho), 2002, págs. XI-CXXVIII.

12 En este sentido explícitamente y con fundamentación, MONEREO PÉREZ, J.L.: Derechos sociales de la ciudadanía y ordenamiento laboral, Madrid, Ed. Consejo Económico y Social de España, 1996, Capítulo III, sobre "una estrategia de ciudadanía basada en los derechos y en los poderes colectivos: las dos formas de concebir y extender la ciudadanía", págs. 159 y sigs.

13 MONEREO PÉREZ, J.L.: La dignidad del trabajador. Dignidad de la persona en el sistema de relaciones laborales, Murcia, Laborum, 2019.

14 MONEREO PÉREZ,J.L.: Pluralismo jurídico y Derecho social: La sociología del Derecho de Gurvitch, Estudio Preliminar a la obra de GURVITCH,G.: Elementos de sociología jurídica, Granada, Editorial Comares (Col. Crítica del Derecho), 2001, págs. XIII-CXLVI; MONEREO PÉREZ,J.L.: La democracia en crisis: Harold J. Laski, Barcelona, Ediciones de Intervención Cultural/El Viejo Topo, 2004; MONEREO PÉREZ, J.L.: "Democracia social y económica en la metamorfosis del estado moderno: Harold J. Laski", 
participantes someten a discusión el espacio cultural y social en que se encuentran inmersos, y tratan de instaurar un nuevo tipo de solidaridad con los demás participantes en el proceso colectivo originado. Ellos tienen la conciencia de constituir una colectividad que busca la cohesión interna y se articula frente al sistema social externo; es decir, producen una nueva solidaridad social. Es así que los fenómenos colectivos de grupo determinan la creación de nuevas agrupaciones sociales, dotadas de una solidaridad propia y específica, por lo que, asimismo, originan la aparición en la escena social de nuevos protagonistas o sujetos colectivos15.

En la sociedad contemporánea estas formas de Derecho autónomo extraestatal están en pleno proceso de expansión precisamente por la complejidad del tejido social de las sociedades actuales y su creciente fragmentación "interna" (nacional) y "externa" (internacional o global). La globalización16 genera en sí nuevas formas de Derecho autónomo (nueva "lex mercatoria")17 y acrecienta la interferencia permanente entre sistemas de Derecho diversos que coexisten entre sí. En la práctica el fenómeno de la globalización está vinculado a la transnacionalización del Derecho18. De este modo el carácter complejo de la experiencia jurídica, determinante del pluralismo jurídico subyacente, implica la necesidad de establecer una verdadera teoría pluralista del

\begin{abstract}
en Lex Social: Revista De Derechos Sociales, 11(1), 298-377 (2021). https://doi.org/10.46661/lexsocial.5426; MONEREO PÉREZ, J.L.: La defensa del Estado Social de Derecho. La teoría política de Hermann Heller, Barcelona, Ediciones de Intervención Cultural/El Viejo Topo, 2009. En una perspectiva más amplia, respecto al lugar de la solidaridad en el constitucionalismo democrático-social, MONEREO PÉREZ, J.L.: Derechos sociales de la ciudadanía y ordenamiento laboral, Madrid, Ed. Consejo Económico y Social de España, 1996, págs. 19 y sigs.; MONEREO PÉREZ, J.L.: La reforma social en España: Adolfo Posada, Madrid, Servicio de Publicaciones del Ministerio de Trabajo y Asuntos Sociales, 2003, espec., págs. 232 y sigs. (sobre los fundamentos de la revisión de la cuestión liberal del trabajo), y págs. 356 y sigs. (respecto a la "Teoría e ideología del liberalismo social reformista"); MONEREO PÉREZ, J.L.: La protección de los derechos fundamentales. El modelo europeo, Albacete, Ed. Bomarzo, 2009, Capítulo 4, págs. 39 y sigs. (sobre la "Constitución del Trabajo y derechos sociales de la ciudadanía", y el "Significado de las Declaraciones de Derechos Sociales: Idea social y democracia participativa. La aportación de Georges Gurvitch a la teoría de las Declaraciones de Derechos Sociales"); MONEREO PÉREZ, J.L.: "Teoría general de los derechos económicos, sociales y culturales (Artículo 22 DUDH, Preámbulo y Artículos 1 a 5 PIDECS y normas concordantes)", en MONEREO ATIENZA, C. y MONEREO PÉREZ, J.L. (Dirs.) et altri: El Sistema Universal de los Derechos Humanos. Estudio sistemático de la declaración de los derechos humanos, el pacto internacional de derechos civiles y culturales y textos internacionales concordantes, Granada, Ed. Comares, 2014, págs.445-514.

15Sobre ello puede consúltese ALBERONI, F.: Movimiento e institución. Teoría general, Madrid, Editora Nacional, 1984, págs.35 y sigs.

16Hace notar Habermas que "el Estado cosmopolita ya ha dejado de ser un puro fantasma, aun cuando nos encontremos todavía bien lejos de él. El ser ciudadano de un Estado y el ser ciudadano del mundo constituyen un continuum cuyos perfiles empiezan ya al menos a dibujarse". Cfr. HABERMAS, J.: Facticidad y validez. Sobre el derecho y el Estado democrático de derecho en términos de teoría del discurso, Madrid, Trotta, 1998, pág.636.
\end{abstract}

17 MONEREO PÉREZ, J.L.: La metamorfosis del Derecho del Trabajo, Albacete, Ed. Bomarzo, 2017, espec., Capítulo II.4 ("La ordenación jurídica de las relaciones laborales y la emergencia de nuevas fuentes reguladoras en la dialéctica entre heteronomía y autonomía”), págs. 44 a 109; MONEREO PÉREZ, J.L.: "La racionalización jurídica de las relaciones laborales y la emergencia de nuevas fuentes reguladoras en el orden internacional”, en Lex Social. Revista Jurídica de los Derechos Sociales, vol. 8, núm.1 (2018), págs. 1 a 44.

18Véase FRIEDMAN, L.M.: "Verso una sociologia del diritto transnazionale", en Sociología del diritto, XX, 1993, 1, págs. 39 y sigs. 
Derecho19, capaz de dar cuenta y de conformar también todas las variedades de la experiencia jurídica, que sitúan al hombre con la realidad. Ahora bien, para él la sociología jurídica no puede traducirse en una teoría puramente sociológica del Derecho, ésta última sería inadecuada para pasar por la prueba del problema de las fuentes del Derecho positivo20. En un mundo globalizado se complejiza el pluralismo jurídico y las escalas del Derecho, coexistiendo e interrelacionándose -a menudo conflictivamente- lo local, lo nacional y lo global. La realidad es que existe una pluralidad de órdenes jurídicos con lógicas operativas propias, coexistiendo el pluralismo clásico -ligado a los debates sobre el colonialismo- con un nuevo pluralismo que deriva de la complejidad del mundo moderno21. Lo que es evidente es que no todos los fenómenos jurídicos tienen su origen en el Derecho estatal, ni en el Derecho considerado oficial. La experiencia jurídica muestra la existencia de una juridicidad no estatal (un Derecho realmente existente y dotado de eficacia regulativa). El pluralismo jurídico supone la existencia en la realidad jurídica de una multiplicidad de órdenes jurídicos que pueden coexistir en un mismo espacio y tiempo, cuestionando la pretensión del monismo estatal en la producción de normas de Derecho objetivo. Tampoco el Estado -aunque lo pretendiera- está en condiciones de gobernar jurídicamente por sí solo y de manera unitaria los conflictos y antagonismos sociales que emergen en sociedades tan complejas con las del capitalismo tardío.

Agréguese que para Gurvitch la experiencia jurídica inmediata representa la base constitutiva común para la sociología del Derecho, la filosofía jurídica e incluso para la ciencia jurídico-dogmática. Sin llegar a confundir sus respectivos campos de intervención (y sin pretender fundar una ciencia jurídica integral al estilo del pensar de Ross22 o de Geiger23), Gurvitch trata de establecer los nexos existentes entre ambas disciplinas jurídicas, como único expediente para dar cuenta de la complejidad del fenómeno jurídico.

\footnotetext{
19Parte de ese intento constructivo puede hallarse en $L^{\prime}$ Expérience Juridique et la Philosophie Pluraliste du Droit, París, Pedone, 1935, págs.138 y sigs. ("Teorías pluralistas de las fuentes del Derecho positivo"). Para Gurvitch el problema de las fuentes del Derecho positivo constituye el problema crucial de toda reflexión jurídica (Ibid., pág.138).

20 Vid. L'Expérience Juridique et la Philosophie Pluraliste du Droit, París, Pedone, 1935, pág.139.

21 SOUSA SANTOS, B.D.: Sociología crítica. Para un nuevo sentido común en el derecho, Nota introductoria y revisión de la traducción de Carlos Lema Añon, Madrid, Ed. Trotta, 2009, espec., págs. 52 y sigs.

22ROSS, A.: Lógica de las normas, trad. S.-Hierro, revisión, edición y estudio preliminar, "Alf Ross, la ambición de la teoría realista del Derecho" (pp. XI-CXXXVI), a cargo de J.L. Monereo Pérez, Granada, Ed. Comares (Col. Cr'tica del Derecho), 2000; ROSS, A.: Teoría de las fuentes del Derecho, Estudio preliminar de Muñoz de Baena Simón y otros, Madrid, CEPC, 1999; ROSS, A.: Hacia una ciencia realista del Derecho, trad. J. Barboza, Buenos Aires, Abeledo-Perrot, 1961; ROSS, A.: Sobre el Derecho y la justicia, trad. G. R. Carrió, Buenos Aires, Eudeba, 1963.

23 GEIGER, TH.: Estudios preliminares de sociología del Derecho, con una introducción y una bibliografía internacional a la sociología del derecho por Paul Trappe, traducción de Arturo Camacho, Guillermo Hirata y Ricardo Orozco; edición al cuidado de J.L. Monereo Pérez, Granada, Ed. Comares (Col. Crítica del Derecho), 2001.
} 
En términos de colaboración interdisciplinar al estilo diverso de Holmes24 o de Pound25, o, menor medida, Gény26.

Una preocupación constante en el pensamiento de Gurvitch es dar cuenta en el plano de la teoría sociológica de la complejidad de lo real, forjando conceptos técnicos que permitan ajustar una materia social esencialmente heterogénea y cambiante. Sus sistematizaciones científicas, sus clasificaciones conceptuales, trataban de aprehender una materia social compleja y de contornos ambiguos o difusos.

Es necesario realzar, primeramente, que su formación inicial, y dentro de una primera larga fase de construcción de su pensamiento jurídico-social, era esencialmente filosófica. Por ello hasta el momento de su mayor inclinación hacia la sociología jurídica como disciplina autónoma (el Gurvitch más propiamente sociológico)27, Gurvitch intentará fundamentar la sociología del Derecho desde la filosofía jurídica28. No en vano se ha hecho referencia a la tendencia en Gurvitch "a hacer coincidir la sociología con la filosofía" esencialmente ecléctica de la cual participa, sobre todo a través de las concepciones filosóficas de Fichte, Scheler y Bergson29. Por lo demás, Gurvitch reivindica un estatuto propio para la ciencia del Derecho, la cual no debería reconducirse sin más a una pura teoría sociológica que desatendiera la especificidad de lo jurídico, aunque es muy ambigua la distinción que

24 HOLMES Jr, O.W.: The Common Law, trad. Fernando N. Barrancos y Vedia, revisión, edición y estudio preliminar, "La crítica iusrealista del formalismo jurídico de la cultura del "Common Law" tradicional: la concepción funcional e instrumental del Derecho de Oliver Wendell Holmes” (pp. IX-XLIX), por J.L. Monereo Pérez, Granada, Ed. Comares (Col. Crítica del Derecho), 2020; HOLMES, O.W.: La senda del Derecho, Buenos Aires, Abeledo-Perrot, 1975.

25 POUND, R.: La Evolución de la Libertad. El desarrollo de las garantías constitucionales de la libertad, edición y estudio preliminar, 'La 'jurisprudencia sociológica' de Roscoe Pound: La teoría del Derecho como ingeniería social” (pp. IX-LXXXIII), a cargo de J.L. Monereo Pérez, Granada, Ed. Comares, 2004; POUND, R.: Las grandes tendencias del pensamiento jurídico, trad. y estudio preliminar (pp. IXXXXVIII), a cargo de J. Puig Brutau, Granada, Ed. Comares, 2004

26 GÉNY, F.: Método de interpretación y fuentes en Derecho privado positivo, edición y estudio preliminar, "El pensamiento científico jurídico de Gény" (pp. XVII-LXXV), a cargo de J.L. Monereo Péerez, Granada, Ed. Comares (Col. Crítica del Derecho), 2000; GÉNY, F.: La libertad en el Derecho. Entre certeza e incertidumbre, Selección de textos e Introducción por María José Bernuz Beneitez, Granada, Ed. Comares (Col. Crítica del Derecho), 2006.

27Algo que se produce a través de obras de carácter no jurídico ("Dialectiva y sociología", "Los marcos sociales del conocimiento", "La vocación de la sociología"...) y que culmina con el capítulo de un Tratado dedicado a la sociología jurídica donde explícitamente la desvincula de toda previa fundamentación iusfilosófica. Cfr. GURVITCH, G.: "Problèmes de sociologie du droit", en Traité de sociologie, t.II., $4^{\mathrm{a}}$ ed., París, PUF, 1962, págs. 173 y sigs.

28Es por ello quizá discutible, porque sólo sería aplicable al primer Gurvitch, la posición de DÍAZ, E.: Sociología y Filosofía del Derecho, $2^{\text {a }}$ ed., Madrid, Ed. Taurus, 1980, pág.151, cuando afirma que el de Gurvitch es quizás el último de los grandes sistemas que han precedido al establecimiento definitivo de la sociología como ciencia plenamente autónoma.

29Véase TREVES, R.: La sociología del Derecho. Orígenes, investigaciones, problemas, trad.M.Atienza, M J J.Añon Roig y J.A.Pérez Lledó, Madrid, Ariel, 1988, pág.118. Ello influye en la misma definición de Gurvitch de la sociología del Derecho, ya que la concibe como "la parte de la sociología del espíritu humano que estudia en su plenitud la realidad del Derecho...". GURVITCH, G.: Sociología del Derecho, Argentina, Ed.Rosario, 1945. Sobre la influencia de estas direcciones de pensamiento en la sociología del Derecho de Gurvitch, véase TANZI, A.: Georges Gurvitch e il progetto della libertà, Pisa, Pacini, 1980, passim. Es de interés, al respecto, el ensayo de GURVITCH, G.: "Deux aspects de la philosophie de Bergson: temps et liberté”, en Revue de métaphisique et de morales, 1960, págs. 307 a 316. 
establece entre "teoría sociológica del Derecho" y "sociología jurídica"30. Por ello se sitúa en un punto intermedio entre la doctrina jurídica que según él ha reducido unilateralmente la ciencia del Derecho a una sociología jurídica ("sociologismo")31 y aquélla que tiende a realzar la dimensión normativa del Derecho hasta el punto de relegar a un segundo plano el espacio propio de la sociología jurídica32. Piensa Gurvitch que la sociología del Derecho constituye una ciencia dotada de autonomía frente a la ciencia jurídica formal o dogmática jurídica.

El pensamiento filosófico de Gurvitch nace íntimamente vinculado a la filosofía de Leibniz y al idealismo de Fichte33. En este sentido Gurvitch construye su sistema de pensamiento con base a la idea de sistema de integración o síntesis de elementos autónomos como fenómenos sociales totales (cada uno de ellos), donde se agrupan en un todo interdependiente (unidad plural y diversificada) los distintos ámbitos de la experiencia humana, como la sociología, el Derecho, la psicología, la moral, la filosofía, la historia, etcétera34. Un factor de complejidad deriva del carácter dinámico y dialéctico que caracteriza a todos los sistemas sociales. La misma visión de Gurvitch del pluralismo jurídico-democrático refleja la idea de integración y variación de intereses y valores en la sociedad democrática, en una síntesis dinámica e históricamente mutable (síntesis entre libertad e igualdad en base a la fraternidad, de tal manera -dice- que "la igualdad no es identidad sino equivalencia entre individuos y grupos diferentes, así como equivalencia entre

30Véase GURVITCH, G.: Sociología del Derecho, Argentina, Ed.Rosario, 1945, págs.73 y sigs.

31Sería el caso de EHRLICH, E.: I fondamenti della sociologia del diritto, Milano, Giufrè, 1976.

32Sería el caso -siempre según la opinión de Gurvitch- de WEBER, M.: Economía y sociedad, trad. de J. Medina Echavarría y otros, México, Ed. FCE, 1983.

33Véase explícitamente, GURVITCH, G.: L'Idée du Droit Social. Notion et Système du Droit Social, París, Sirey, 1932 (reimpresión alemana de la edición de París de 1932, Scientia Verlag Aalen-1972), Cuarta Parte, cap.1, págs.407 y sigs (Fichte contra Hegel. La sociedad y el Estado en el transpersonalismo sintético de Fichte y en sub-individualismo jerárquico de Hegel).

34Véase ampliamente NIETO CÁNOVAS, C.: Georges Gurvitch: de la filosofía a la sociología del conocimiento, Alicante, Institut de Cultura "Juan Gil-Albert", 1995, passim. 
todas las partes"35)36. También la coexistencia plural de los grupos37 (los "nosotros" en el interior de los grupos) pone de relieve una mutua interacción e influencia que a lo largo de la histórica se especifica en momentos de conflicto y de cooperación. Esta visión vincula igualmente su pensamiento con la fenomenología (Husserl y Scheler)38 que atiende a la realidad concreta y al dato de la experiencia vivida en un flujo permanente, haciendo del análisis de lo concreto un camino para evitar incurrir en la esterilidad de los razonamientos especulativos de la razón y de los planteamientos puramente abstractos, permanentes y apriorísticamente universalizantes. A este cúmulo de influencias se suma la rica incidencia del pragmatismo de W.James39 y del pensamiento "intuicionista" de Bergson40 y Rauh41.

35Cfr. GURVITCH, G.: La Déclaration des Droits Sociaux, New York, Editions de la Maison Française, 1944, $1^{a}$ Parte, VI, págs.59-60 (ed. francesa, París, Vrin, 1946). Nótese que para Gurvitch la democracia es democracia social, sustancial y participativa, asentada sobre el principio de igualdad material, siendo capaz de armonizar la libertad individual con la idea de igualdad. Véase GURVITCH, G.: "Le príncipe démocratique et la démocratie future", en Revue de métaphisique et de morale, 1929, págs. 403 a 431, en particular págs. 405406. Esa democracia sustancial y participativa tiene como objetivo esencial alcanzar una síntesis entre el individualismo y el universalismo. De ahí que la democracia auténtica se realice a través de un tipo particular de Derecho, el Derecho social, que estaría llamado a desplazar al Derecho individual. En coherencia, la democracia es definida por Gurvitch como la institución de la soberanía del Derecho social, en el interior de una organización cualquiera que sea. Pero el principio democrático es un principio tanto organizador del Estado como de la propia sociedad, que penetra, pues, en la estructura social (en la "sociedad económica"). Ella es el marco idóneo para conseguir un nuevo equilibrio entre la sociedad y el Estado. En su expresión formal, el ideal democrático expresado en la soberanía del Derecho social supone que toda totaldiad social se afirma como la fuente de un nuevo Derecho objetivo y participa directamente en las relaciones jurídicas internas a que da lugar. Esta forma de Derecho social autónomo simbolizaría jurídicamente y enarnaría la idea de un autogobierno colectivo a base de igualdad y libertad. Para él la democracia presenta una multiplicidad de aspectos, tiene un carácter poliédrico, en su continuo extenderse a nuevas regiones de relaciones humanas, en el hecho de que excede de los límites exclusivos de la organización política institucional. Cfr. GURVITCH, G.: "Le príncipe démocratique et la démocratie future", en Revue de métaphisique et de morale, 1929, págs. 419 y sigs.

36GURVITCH, G.: La Vocation actuelle de la sociologie: vers une sociologie différentielle, vol.I, PUF, 1963 (Trad. La vocación actual de la sociología, trad.P.González Casanova, Max Aub y S.de la Fuente, México, F.C.E., 1953).

37Vid.infra.

38Georges Gurvitch fue uno de los autores que tuvo un papel decisivo en la introducción de la sociología fenomenológica en Francia.

39Sobre la influencia en Gurvitch del empirismo radical de W.James, véase TANZI, A.: Georges Gurvitch. Il progetto della libertà, Pisa, Pacini, 1980, págs.101 y sigs.

40Sobre la influencia del intuicionismo en Gurvitch, véase TOULEMONT, R.: Sociologie et pluralisme dialectique. Introduction à l'oeuvre de Georges Gurvitch, Louvain-París, ed. Nauwelaerts, 1955, passim. No obstante, el intuicionismo de Bergson se enmarca en la siempre persistente influencia de la filosofía de Fichte, quien -como subraya el propio Gurvitch- caracteriza la intuición volitiva que nos hace entrever la libertad creadora o el bien, en un sentido enteramente opuesto a la intuición mística de Dios. De manera que, "nuestra voluntad clarividente, nuestra intuición volitiva, guiada por sus propias luces que surgen en la acción misma, siendo todo el elemento más personal del yo, en lugar de aislarnos, nos integra en un flujo transpersonal de la actividad creadora, ubicada en la duración y englobando todas las voluntades personales. Constituyendo una Gemeinde der Iche, una reciprocidad total de perspectivas entre la multiplicidad infinita de las conciencias y su unidad, una totalidad inmanente en la que el todo y las partes se engendran recíprocamente y se afirman como equivalentes, flujo de la actividad creadora (o libertad material), en cuya participación el individuo se eleva por intuición volitiva, puede ser caracterizada como transpersonal". Cfr. GURVITCH, G.: Morale Théorique et Science des Moeurs: leur possibilités, leurs conditions (1937), París, PUF, $3^{\mathrm{a}}$ ed., 1961, cap.II, Sección $2^{\mathrm{a}}$, págs.52-53.

41El reflejo de esa percepción puede verificarse, ante todo, en su importante obra L'Expérience Juridique et la Philosophie Pluraliste du Droit, París, Pedone, 1935; antes se había detectado esa influencia plural de la 
Con estas influencias Gurvitch construye su propio pensamiento crítico, y lo hace partiendo de la idea de que las distintas experiencias (de las ideas, de los valores, religiosa, metafísica...) no son sino diferentes aspectos del empirismo radical de lo inmediato o construido. Ahora bien, para él "la experiencia integral de lo inmediato no es, sin embargo, ni conocimiento filosófico ni conocimiento científico42. Lo "conocido" es siempre más complejo que lo "dado" (incluso más actual)43, porque supone una síntesis reflexiva (juicio), no pudiendo expresar jamás de manera adecuada los datos probados. La experiencia inmediata no es más que uno de los elementos constitutivos del conocimiento filosófico, la raíz que le procura alimento. La experiencia integral de lo inmediato, representando las intuiciones temporalizadas (ubicadas en las duraciones) e infinitamente variables, es una experiencia de lo material y de lo espiritual, de lo sensible y de lo ideal, del ser real y de los valores"44. Por ello mismo podría hacer suya la reflexión de autores como C. Wright Mills en el sentido de que no es posible que los especialistas en ciencias sociales eviten los juicios de valor o que dejen de incluirlos en el conjunto de su obra. Los problemas, como las situaciones y las dificultades, implican amenazas a los valores esperados, y no pueden ser formulados claramente sin el reconocimiento de dichos valores. Por el hecho mismo de su existencia todos los especialistas en ciencias sociales están implicados en la lucha entre la ilustración y el oscurantismo45.

Precisamente "la sociología jurídica considera la variedad cuasi-infinita de las experiencias de todas las sociedades y de todos los grupos, describiendo los contenidos concretos de cada tipo de estas experiencias (en tanto que son expresadas en fenómenos exteriormente observables) y que muestran la realidad plena del derecho que los símbolos más que expresan ocultan"46. Por lo demás, entiende que la teoría de la experiencia jurídica permite situar adecuadamente la relación entre sociología jurídica y Filosofía del Derecho47. En efecto, para él sólo una teoría de la experiencia jurídica inmediata y de la singularidad infinita

filosofía alemana en Les Tendences Actuelles de la Philosophie Allemande. E.Husserl, M.Scheler, E.Lask, N.Hartmann, M.Heidegger, Préface de Léon Brunschvig, París, Vrin, 1930.

42Nótese que Gurvitch definió la sociología del conocimiento como el estudio de las relaciones (correlaciones funcionales) entre los diversos marcos o cuadros sociales (sociedades globales, clases, grupos) y los distintos tipos de conocimiento. Véase GURVITCH, G.: Los marcos sociales del conocimiento (1966), Caracas (Venezuela), Monte Ávila Editores, 1969. Gurvitch prefiere distinguir distintas esferas de conocimiento. En particular, entiende en dicha obra que el conocimiento político constituye una combinación de la fe en un ideal con el conocimiento indispensable para sortear los obstáculos y captar las oportunidades en el momento en que se presentan. Sobre la influencia en Gurvitch del empirismo radical de W.James, véase TANZI, A.: Georges Gurvitch. Il progetto della libertà, Pisa, Pacini, 1980, págs.101 y sigs.

43 Sobre "lo dado" y "lo construido", véase GÉNY, F.: Método de interpretación y fuentes en Derecho privado positivo, edición y estudio preliminar, "El pensamiento científico jurídico de Gény” (pp. XVIILXXV), a cargo de J.L. Monereo Péerez, Granada, Ed. Comares (Col. Crítica del Derecho), 2000.

44Cfr. GURVITCH, G.: Morale Théorique et Science des Moeurs: leur possibilités, leurs conditions (1937), París, PUF, $3^{\mathrm{a}}$ ed., 1961, cap.II.4º ${ }^{\circ}$ Sección, págs.88-89.

45 WRIGHT MILLS, C.: La imaginación sociológica (1959), trad. F. M. Torner, Prólogo de Gino Germani, México D.F., Ed. FCE, 1986, págs. 23 y sigs. y 134 y sigs.

46Cfr.GURVITCH, G.: Elementos de sociología jurídica, cit., pág. 34.

47Adviértase que para Henri Lévy-Bruhl el Derecho es el conjunto de reglas obligatorias que determinan las relaciones sociales impuestas en todo momento por el grupo al que se pertenece. Véase LÉVY-BRUHL, H.: Sociologie du droit, París, PUF, 1964 (Sociologia do direito [1961], Sao Paulo, Livraria Martins Fontes Editora Ltda, $2^{\circ}$ ed., 1997). 
de sus datos espirituales, puede resolver el problema de la relación entre la sociología jurídica y la Filosofía del Derecho. Dicha experiencia, hacia la cual reconduce la Filosofía del Derecho por un procedimiento de inversión y de reducción, es al mismo tiempo la base de la sociología jurídica. Estas dos disciplinas representan dos maneras distintas de utilizar los datos de esta experiencia, afirmándose como ramas interdependientes del saber sobre el Derecho48.

\section{Pensamiento social: Los grupos sociales y su Derecho autónomo extraestatal}

Esta cosmovisión filosófica de Gurvitch ha influido decisivamente en sus concepciones sobre el Derecho, la moral y la sociedad democrática. En el campo del Derecho se traduce en la constante defensa del pluralismo jurídico; en el campo moral por su compromiso con los valores de la libertad49, la justicia y la fraternidad50; y, en el terreno político constitucional por postular un orden democrático-social basado en el pluralismo político y social y en la democracia económica y en la democracia industrial. Hay que llamar la atención sobre el dato innegable que su concepción de los derechos sociales reflejadas en diversas obras y en particular en su propuesta de La Déclaration des Droits Sociaux (1944)51, la cual tuvo un influencia extraordinaria en diversos instrumentos internacionales como la Declaración de los Derechos Humanos de 1948 (adoptada y proclamada por la 183 Asamblea General de la ONU en 10 de diciembre de 1948), el Pacto de Derechos Económicos, Sociales y Culturales de 1966 (de 19 de diciembre de 1966), la Carta Social Europea (tanto en la versión originaria de 18 de octubre de 1961 como en la versión revisada de 1996), la Carta de los Derechos Sociales Fundamentales de los Trabajadores de 1989 (Aprobada como Declaración de Política del Derecho por la entonces denominada Comunidad Europea; firmada en Estrasburgo el 9 de diciembre de 1989, sin rango

48Cfr. GURVITCH, G.: Elementos de sociología jurídica, cit., pág. 40.

49Véase ABAGNANO, N.: "La sociologie de la liberté: Georges Gurvitch", en Revue de métaphysique et de Morale, 1956, págs.78 a 86.

50Para la concepción de Gurvitch sobre la idea de justicia y la justicia material, véase GURVITCH, G.: L'Expérience Juridique et la Philosophie Pluraliste du Droit, París, Pedone, 1935, págs.97 y sigs.; GURVITCH, G.: La Déclaration des Droits Sociaux, New York, Editions de la Maison Française, 1944 (ed., francesa, París, Librairie Philophique J.Vrin, 1946), passim.

51 GURVITCH, G.: La Déclaration des Droits Sociaux, New York, Editions de la Maison Française, 1944 (ed., francesa, París, Librairie Philophique J.Vrin, 1946), passim. Un estudio detenido de esta Declaración de Derecho Sociales, sus rasgos fundamentales, significación político jurídica e influencia en las Declaraciones de Derechos aprobadas en la segunda postguerra mundial, en MONEREO PÉREZ, J.L.: Pluralismo jurídico y Derecho social: La sociología del Derecho de Gurvitch, Estudio Preliminar a la obra de GURVITCH, G.: Elementos de sociología jurídica, Granada, Editorial Comares (Col. Crítica del Derecho), 2001, págs.13146; MONEREO PÉREZ, J.L.: Democracia pluralista y Derecho Social. La teoría crítica de Georges Gurvitch, Barcelona, Ediciones de Intervención Cultural/El Viejo Topo, 2021. MONEREO PÉREZ, J.L.: La protección de los derechos fundamentales. El Modelo Europeo, Albacete, Ed. Bomarzo, 2009, contiene un capítulo expresamente dedicado a la aportación de Georges Gurvitch a las Declaraciones y Textos Internacionales aprobados a partir de la Segunda Postguerra Mundial dentro del sistema internacional de garantía de los derechos fundamentales. Un estudio general, MONEREO ATIENZA, C. y MONEREO PÉREZ, J.L. (Dirs. y Coords.): El Sistema Universal de los Derechos Humanos. Estudio Sistemático de la declaración de los derechos humanos, el pacto internacional de derechos civiles y políticos, el pacto internacional de derechos económicos, sociales y culturales y textos internacionales concordantes, Granada, Ed. Comares, 2014, 1043 págs. 
normativo, por once de los Jefes de Estado o de Gobierno de los doce Estados miembros de la Comunidad Europea, con adhesiones posteriores de los nuevos Estados miembros que se iban incorporando)52 y la Carta de los Derechos Fundamentales de la Unión Europea (versión originaria el 18 de diciembre de 2000 como Declaración de Política del Derecho, y la versión definitiva de 2007 con rango específico de Tratado de la Unión Europea, conforme a lo establecido en el art. 6.1 del Tratado de la Unión Europea, en redacción dada ya en su momento por el Tratado de Lisboa). Esa influencia se hace extensible a su obra mayor en el campo fundante de la Idea Social y del propio Derecho Social, a saber: La Idea del derecho social (1932)53.

La instauración de una democracia auténtica (democracia "real") exige un nuevo proceso constituyente a fin de dar vida a una nueva constitución democrático-social, que recogiera los nuevos derechos sociales fundamentales54. En este sentido es cómo cabe interpretar su

52 En esto hay que distinguir entre Declaraciones y Garantías de los Derechos. Al respecto puede consultarse, MONEREO PÉREZ, J.L.: "Carta comunitaria de los derechos fundamentales de los trabajadores” (I y II), en Civitas. Revista Española de Derecho del Trabajo, núm.56-57 (I/1992-II/1993), núm. 56, págs. 844-898, y núm. 57, págs. 61-90, reivindicando, no obstante, su valor como principios generales del Derecho Social Comunitario (criterio que sería acogido por el Tribunal de Justicia Comunitario), y distinguiendo entre Declaraciones y Garantías de los Derechos Fundamentales. Al respecto, asimismo, MONEREO PÉREZ, J.L.: La protección de los derechos fundamentales. El Modelo Europeo, Albacete, Ed. Bomarzo, 2009; MONEREO ATIENZA, C. y MONEREO PÉREZ, J.L. (Dirs. y Coords.): La Europa de los Derechos. Estudio Sistemático de la Carta de los Derechos Fundamentales de la Unión Europea, Granada, Ed.Comares, 2012, espec., estudio de MONEREO PÉREZ, J.L. del "Título VII. Disposiciones que rigen la interpretaicón y la aplicación de la Carta, artículos 51-54”, págs. 12991444.

53 GURVITCH, G. (1932/2005): L’ idée du droit sociale, París, Ed. Sirey, 1932; y su traducción al castellano, Gurvitch,G.: La idea del derecho social, traducción, edición y estudio preliminar, "La idea del derecho social en la teoría general de los derechos: El pensamiento de Gurvitch" (pp. VII-LV), a cargo de J.L. Monereo Pérez y A. Márquez Prieto, Granada, Ed. Comares (Col. Crítica del Derecho), 2005. Sobre la Carta Social Europea Revisada y sus fundamentos, véase exhaustivamente el estudio sistemático en MONEREO ATIENZA, C. Y MONEREO PÉREZ, J.L. (Dirs. y Coords.): La garantía multinivel de los derechos fundamentales en el Consejo de Europa. El Convenio Europeo de los Derechos Humanos y la Carta Social Europa, Granada, ed. Comares, 2017, Parte II ("Carta Social Europea”), págs. 357-1005, y SALCEDO BELTRÁn, C. (Dir.): La Carta Social Europea. Pilar de recuperación y sostenibilidad del modelo social europeo. Homenaje al Profesor José Vida Soria, Valencia, Tirant lo Blanch, 2021. Asimismo, MONEREO PÉREZ, J.L.: La garantía de los derechos de seguridad social en la Carta Social Europea en tiempos de crisis, Murcia, Laborum, 2021. Aportaciones importantes son las que vienen realizando Luis Jimena Quesada y Carmen Salcedo Beltrán; así, entre otras muchas, JIMENA QUESADA, L.: Social Rights and Policies in the European Union. New challenges in a context of economic crisis, Valencia, Tirant lo Blanch, 2016; JIMENA QUESADA, L.: "La consagración del control de convencionalidad por la Jurisdicción Constitucional en España y su impacto en materia de derechos sociolaborales (Comentario a la STC 140/2018, de 20 de diciembre)", en Revista General de Derecho del Trabajo y de la Seguridad Social, no 53 (2019), págs. 434-461; ALFONSO MELLADO, C., JIMENA QUESADA, L., y SALCEDO BELTRÁN, C.: La jurisprudencia del Comité Europeo de Derechos Sociales frente a la crisis económica, Albacete, Bomarzo, 2014.

54Véase entre nosotros POSADA, A.: La reforma constitucional, Madrid, Librería General de Victoriano Suárez, 1931, capítulo preliminar, págs.1 y sigs. Sobre el tema MONEREO PÉREZ, J.L.: Fundamentos doctrinales del Derecho social en España, Madrid, Trotta, 1996.; MONEREO PÉREZ, J.L.: "El pensamiento jurídico-social de Fernando de los Ríos y su Generación", en CÁMARA, G. (ed.): Fernando de los Ríos y su tiempo, Granada (Universidad), 2000, págs.85 y sigs. Sobre el pensamiento de Posada remito al tratamiento completo y exhaustivo realizado en MONEREO PÉREZ, J.L.: La reforma social en España: Adolfo Posada, Madrid, Servicio de Publicaciones del Minsiterio de Trabajo y Asuntos Sociales, 2003, 515 páginas, espec., Capítulo II ("Crisis del Estado de Derecho Liberal y Reforma Constitucional: El reformismo social como 
propuesta sobre la Declaración de los Derecho sociales (1944)55, anticipándose en muchos aspectos a la evolución que tendría el constitucionalismo social de la postguerra. En su realización ve un fenómeno emergente hacia la transformación política, social y jurídica en la experiencia solidaria de los grupos, los cuales pueden explorar las fronteras de lo posible y extender la experiencia de solidaridad a todo el sistema social. Así el Derecho social expresión jurídica o formal de la solidaridad de los grupos- contendría en sí un germen o proyecto histórico superador de las formas organizativas y de agregación jurídica y política existentes. El Derecho social autónomo sería, pues, una vía de transición de lo social, que incorporaría una solidaridad contrapuesta a las formas de sociabilidad dominantes en el sistema social histórico.

Para Gurvitch, los derechos sociales no contemplan al hombre abstracto (ciudadano indiferenciado), sino al hombre concreto y específico, atendiendo a su diferenciada posición en la estructura social, en el ámbito de la producción y en la esfera del consumo. Todas ellas son facetas que los derechos sociales deben contemplar para dar cuenta la multiplicidad de las dimensiones de la experiencia humana.

En el terreno de la política apuesta decididamente por un sistema democrático pluralista, donde el Estado tiene que tener un importante papel, en sus funciones garantistas y apoyo a los individuos y grupos sociales. Gurvitch puede participar de una concepción dinámica y sustancial de la democracia en virtud de la cual la democracia llevaría en sí una promesa perenne de movimiento, por lo que requiere ser permanentemente desafiada por los movimientos, y sólo se re-afirma en la medida en que los movimientos re-descubren el método formal como institución propia; es decir, la democracia formal (necesaria) es puesta constantemente en crisis por una exigencia de democracia sustancial por parte de nuevos movimientos sociales o colectivos. Con todo, la democracia tiene necesidad del movimiento; sin él, se agota y pierde legitimidad. Pero es que, además, la democracia sólo puede existir como forma, específica institucionalización de la promesa del movimiento56. Este el sentido del proceso de institucionalización del orden democrático-social, pero con la importante puntualización de que en el pensamiento de Gurvitch el intercambio entre promesa inherente

alternativa a la crisis del Estado de Derecho Liberal"), págs. 133 y sigs. Asimismo, MONEREO PÉREZ, J.L.: Sindicalismo reformista integrado y Estado democrático en el republicanismo social de Adolfo Posada, estudio preliminar a POSADA, A.: Teoría social y jurídica del Estado. El Sindicalismo (1922), edición y estudio preliminar a cargo de J.L. Monereo Pérez, Granada, Ed. Comares (Col. Crítica del Derecho), 2018, págs. IXLXIX. Por cierto, reténgase GURVITCH, G.:"Reseña: de Adolfo Posada, Les fonction sociales de l' Etat, París, Girard, 1929", en Archives de philosophie du droit et de sociologie juridique, III, 1933, págs. 223226.

55Véase GURVITCH, G.: La Déclaration des Droits Sociaux, New York, Editions de la Maison Française, 1944 (ed., francesa, París, Vrin, 1946), con inclusión del texto articulado propuesto por el propio Gurvitch como Declaración de Derechos Sociales. Un primer análisis crítico puede encontrarse en BOBBIO,N.: "Gurvitch y los derechos sociales", en El tiempo de los derechos, Madrid, Ed.Sistema,1991, págs.27 y sigs.

56Para esa concepción de la democracia consúltese las reflexiones de ALBERONI,F.: Movimiento e institución. Teoría general, Madrid, Editora Nacional, 1984, págs.278 a 280, el cual entiende, por otra parte, que la democracia existe en cuanto "re-nace" y se "re-funda" cada vez como movimiento que se convierte en institución de representación. En realidad, el sistema democrático moderno busca elevar la racionalidad al nivel del valor; es decir, el medio racional es el único garante de la realización de la promesa en la tradición específica occidental. 
a los movimientos sociales y la institución-norma no llevaría una desaparición del fenómeno colectivo. Dicho en otras palabras: para Gurvitch la norma tendería a absorber en sí el valor de la unanimidad lograda a través de la participación activa, pero el movimiento de base debe mantenerse y regenerarse continuamente para hacer emergen nuevos procesos de transformación jurídica e institucional en la sociedad democrática. El proceso de institucionalización de los movimientos colectivos y de su Derecho social no les hace desaparecer del escenario social, manteniendo así ciertos lazos entre los ámbitos del poder constituyente y de los poderes construidos en las sociedades democráticas. De este modo el proceso democrático puede contemplarse como el resultado cambiante de los conflictos derivados de la lucha entre las distintas agregaciones sociales. Pero en el pensamiento de Gurvitch el pluralismo jurídico y político no encuentra un fundamento utilitarista ni tampoco se comporta como una especie de "mercado"57. Gurvitch asumiría fácilmente una concepción participativa y deliberativa de la política que permitiría obtener un consenso dinámico entre las diversas fuerzas operantes en la sociedad democrática, en una circularidad constante entre las colectividades sociales y el sistema político institucional para ellas construidas. La democracia tiene como objetivo esencial garantizar una espacio para la discusión pública y para proceder colectivamente a seleccionar preferencias asumidas a través del consenso más amplio posible, impidiendo una determinación arbitraria e interesada de las mismas58. El poder constituyente detentado y mantenido dinámicamente sería la expresión de un ideal democrático que autentificaría el régimen de democracia representativa a través de los partidos políticos, pues garantizaría una participación activa e inmediata de todos los miembros de la comunidad política. Para Gurvitch ese poder constituyente tiene una fuerza creadora de un orden al cual se somete libremente y respecto del cual pueda impulsar mecanismos para su transformación dinámica. Gurvitch no era un anarquista -a pesar de su admiración por Proudhon-, sino un partidario de la democracia social y económica en sentido socialista; Gurvith tenía una concepción participativa del poder social en una sociedad democrática verdaderamente pluralista59. Buscaba cristalizar un nuevo imaginario político en el ensamblaje entre democracia, ciudadanía activa y sociedad civil. Se trata de propiciar la implantación de un nuevo modelo social no subordinado a la lógica del mercado y de la acumulación del capital, donde el garante de los procesos democratizadores no están sólo en el Estado Social de Derecho, sino ante todo -en su opinión- en una sociedad activa que ejercer sus libertades y defienda y profundiza en la construcción y reinvención constante de sus derechos sociales fundamentales. Es decir, una democracia "desde abajo hacia arriaba", horizontal, y no sólo vertical o estatalista, "desde

57La interpretaicón pluralista "liberal" ve el proceso político como una especie de mercado, de manera que las leyes serías simples mercancías, reflejando números e intensidad de preferencias. Véase SUNSTEIN,C.R.: "Constituciones y democracia: Epílogo", en ELSTER,J.y SLAGSTAD,R.: Constitucionalismo y democracia, México, FCE, 1999, págs.344 y sigs.

58Sobre la política deliberativa y el pluralismo democrático véase más adelante, especialmente, apdo. 3.2.D). 59 Esa dialéctica crear y estar en el orden, pero participando directamente en su transformación desde dentro del sistema democrático está muy presente en la tradición del socialismo democrático y su expresión de socialismo en el Derecho. Véase, ampliamente, MONEREO PÉREZ, J.L.: Fundamentos doctrinales del Derecho Social en España, Madrid, Ed. Trotta, 1999, pág. 18, págs. 21 y sigs., y 191 y sigs. ("Derecho social, socialismo democrático y constitución jurídica de la clase trabajadora"). 
arriba hacia abajo". Así, el sujeto emancipatorio reside en la sociedad civil organizada en grupos sociales -fenómenos colectivos- que dinamizan los procesos sociales. Pretendía implantar un proyecto alternativo de sociedad pluralista cambiando el orden existente a través de nuevos valores de democracia política, ciudadanía activa y de justicia social60. La democracia es método de resolución de conflictos y de organizar la convivencia, el gran problema es cómo realizar el ideal de autogobierno de los ciudadanos y hacerlo en libertad coexistiendo con una democracia representativa pluralista, con cauces de participación a través de instituciones intermedias (asociaciones de diversa índole, sindicatos, partidos políticos) y formas de autogobierno (formas de democracia económica y asociativa)61. En la coyuntura actual se ha planteado que no es posible justificar el capitalismo desde ningún punto de vista, ni económico ni ético; y que, en realidad, existe una alternativa al capitalismo que promete una mayor eficacia y un crecimiento más racional, así como más igualdad, más democracia y un trabajo con sentido. Esta alternativa sería precisamente la "Democracia Económica", que es un socialismo de mercado con planificación descentralizada de las inversiones y democracia en el trabajo. Esta alternativa se podría realizar de manera progresiva a través de posibles formas de transición a la democracia económica desde el capitalismo avanzado y desde el subdesarrollo del Tercer Mundo. La democracia económica organizada puede ser eficiente, superando no sólo el "capitalismo democrático" o el "capitalismo justo" liberal-keynesiano, sino también las formas emergentes de capitalismo antidemocrático con aplicación de políticas neoliberales62. Hay que tener en cuenta que se está transitando actualmente del Estado Social de Derecho a la nueva forma política del "Estado de mercado" o "Estado de competencia económica.

De alguna manera Gurvitch quería transitar del estatismo al pluralismo fomentando una democracia pluralista y asociativa, que presuponía también una transformación del carácter del Estado Social de Derecho para realizar los principios de la democracia asociativa y de la democracia económica. En sus orígenes intelectuales están los llamados "socialistas utópicos", los "socialistas fabianos", pero también otras corrientes de pensamiento que entroncan con Otto von Gierke, Léon Duguit, Émile Durkheim, y algunos de los más importantes autores defesores de la democracia asociativa y de la democracia económica como G.D. H. Cole, Harold J. Laski, Georges Gurvitch, Hugo Sinzheimer (bajo la influencia de de Gierke, expresamente reconocida como referente de la concepción social del

60 Sobre la complementaria existente entre la ciudadanía de los derechos y la ciudadanía de los poderes colectivos, véase MONEREO PÉREZ, J.LL: Derechos sociales de la ciudadanía y ordenamiento laboral, Madrid, Ed. Consejo Económico y Social de España, 1996, págs. 159 y sigs.

61 Puede resultar de interés el examen de las formas democráticas y de la calidad de la democracia llevado a cabo por PRZEWORSKI, A.: Qué esperar de la democracia. Los límites y posibilidades del autogobierno, trad. S. Mastrangelo, Buenos Aires, Siglo Veintiuno Editories, 2010, dónde se interroga sobre la democracia como implementación del autogobierno en las sociedades de nuestro tipo, págs. 249262. Asimismo defendiendo una economía participativa, ALBERT, M.: Parecon. Vida después del capitalismo, Barcelona, Ed. Akal, 2005, págs. 105 y sigs., 203 y sigs. y 269 y sigs.

62 SCHWEICHKART, D.: Más allá del capitalismo (1993), trad. C. Escriche Blancafort, Prólogo de Luis de Sebastián, Santander-Editorial Sal Terrae, Barcelona-Cristianisme i Justícia, 1997, págs. 133 y sigs., 263 y sigs. y 395 y sigs. 
Derecho)63. Lo que conduce a una suerte de Estado pluralista descentralizado64. Pero el propio Gurvitch vería necesaria esa insercación de la democracia industrial en un programa de planificación democrática y descentralizada, pues de lo contrario los trabajadores quedan reubicados las organizaciones productivas como centros de poder con factores base de poder muy limitados y una inoperatividad práctica derivada de la misma desconexión y consiguiente descoordinación con el sistema económico en su conjunto65.

En su visión de la democracia económica Gurvitch pretende extender la democracia en la esfera económica. Por ello acentúa el derecho social de participación a través de fórmulas típicamente de control y "autogestión" de los trabajadores de la vida de las empresas, aunque en La Declaración postula al menos la consagración de un pleno "derecho de participar en la gestión misma de las empresas"66. Para Gurvitch la democracia económica y los derechos sociales son en sí mismos dimensiones del "espacio político" de la sociedad; del mismo modo que la Politica el Derecho son las dos caras de la misma medalla. Por lo demás, el poder es obvio que no se agota en el Estado, sino que abarca todo ese espacio de lo político que penetra en todo el tejido social. El poder remite a estos genios invisibles de la ciudad67; o desde otro punto de vista el poder se despliega en todos los ámbitos de la vida y tanto más cuando en las sociedades complejas se ejercer como poder biopolítico, que no se disuelve en una esfera específica de orden de la sociedad, sino que se hace tangible y materializa en

63 GIERKE, O.VON.: La función social del Drecho privado y otros estudios, trad. J.M. Navarro de Palencia, Revisión, edición y estudio preliminar, "La teoría jurídica y social de Otto von Gierke: Teoría del Derecho Social y de las personas colectivas" (pp. IX-LXI), a cargo de J.L. Monereo Pérez, Granada, Ed. Comares (Col. Crítica del Derecho), 2015.

64 Véase MONEREO PÉREZ, J.L.: La democracia en crisis: Harold J. Laski, Barcelona, Ediciones de Intervención Cultural/El Viejo Topo, 2004; MONEREO PÉREZ, J.L.: "Democracia social y económica en la metamorfosis del estado moderno: Harold J. Laski”, en Lex Social: Revista De Derechos Sociales, 11(1), 298-377 (2021). https://doi.org/10.46661/lexsocial.5426; MONEREO PÉREZ, J.L.: La teoría jurídica y social de Otto von Gierke: Teoría del Derecho Social y de las personas colectivas, estudio preliminar a Gierke, O.von: La función social del Derecho privado y otros estudios, Trad. José M. Navarro de Palencia, revisión y edición a cargo de J.L. Monereo Pérez, Granada, Ed. Comares (Col. Crítica del Derecho), pp. IX-LXI, 2015. Una perspectiva de conjunto, en HIRST, P.: From Statism to Pluralism, Democracy, Civil Society and Global Politics ("Del estatismo al pluralismo. Ensayos sobre la democracia asociativa"), Londres, UCL, Press-Taylor \& Francis, 1997, Capítulos 3 y 4.

$65 \mathrm{La}$ autorreflexión del propio Gurvitch, no exenta de autocrítica implícita en alguna medida, se puede encontrar en trabajos como GURVITCH, G.: "Les voies de la démocratisation industrielle", en Esprit, juin, 1953, págs. 964-972.; GURVITCH, G.: "La répresentation ouvrière et le problème des nationalisations: "conseils de contrôle" et "conseils de gestión", en Esprit, 14, $1^{\circ}$ Février, 1946, págs. 107-112; GURVITCH, G.: "Vers 1' unité ouvrière”, en Esprit, 14, 1 Février, 1946, págs. 270-112; . Y en una reflexion de más largo alcance, GURVITH, G.: "Three paths to selfs-management”, en Self-governing socialism. A reader, vol. II, New York, International Arts and Science Press, Inc., 1975, págs. 20-28 (original escrito en 1957); GURVITCH, G.: “(Perspectives du socialisme:) Le sort des structures sociales actuellesW, Quel avenir attend l' homme? Rencontre international de Royaumon (17-20 Mai 1961), París, PUF, 1961, págs. 151160; GURVITCH, G.:'Democracy as a sociological problema”, Journal of legal and politica sociology, 1, 1942, págs. 46-71.

66GURVITCH, G.: La Déclaration des Droits Sociaux, New York, Editions de la Maison Française, 1944 (ed. francesa, París, Vrin, 1946), pág.86. Sobre esta cuestión son de interés las reflexiones de DUVIGNAD, J.: "Georges Gurvitch, une théorie sociologique de l'autogestion", en Autogestion, núm.1, Anthropos, 1967.

67 FERRERO, G.: El poder. Los genios invisibles de la ciudad, Madrid, Ed. Tecnos, 1998. 
todas ellas68. En este sentido considera esencial establecer mecanismos de democracia en el ámbito general de la vida económica (fórmula de "Consejos Económicos") y profundizar en el "derecho constitucional de las empresas" (la "fábrica constitucional" mediante fórmulas de "democracia industrial")69. Pero también considera preciso que esas fórmulas de democratización se realicen el ámbito internacional70. En realidad la doctrina del derecho obrero y la doctrina del derecho internacional son absolutamente paralelas. En ambos casos se refleja, según piensa Gurvitch, la revuelta contra la supremacía jurídica del Estado desde dentro y desde fuera. Para él un derecho social absorbido por completo por el Estado comporta una cierta desnaturalización, pues una cuestión es la garantía legal de los derechos sociales como derechos -individuales y colectivos- y otra distinta -y complementaria- es la concepción del "Derecho social" como jurídicación de los espacios de autodeterminación social de los colectivos y grupos sociales. De ello es reflejo las distintas experiencias jurídico-institucionales de democracia industrial, en el campo del autogobieno y control colectivo de las organizaciones económicas y la propia negociación colectiva entre las representaciones de los trabajadores y empresarios. En este sentido -0 , si se quiere, acepción- el "Derecho social" es cauce de decisión autónoma y al mismo tiempo mecanismo para defenderse de los poderes públicos (Estado y otros poderes públicos) y privados (los poderes económicos). Ello afecta afecta a la teoría de las fuentes del Derecho, porque es reconocer el pluralismo socio-jurídico de la autonomía colectiva de los grupos; un poder colectivo que está consagrado en el Derecho del Trabajo a través de la libertad sindical y el reconocimiento del derecho a la negociación colectiva71; aunque no se agota, por supuesto, en el ordenamiento jurídico-laboral.

68 FOUCAULT, M.: Microfísica del poder, trad. Horacio Pons, Buenos Aires, Siglo Veintiuno Editores Argentina, 2019.

69Véase GURVITCH, G.: Le Temps présent et l'idée du Droit Social, París, ed.J.Vrin, 1932, págs.55 y sigs.; GURVITCH, G.: "Les voies de la démocratisation industrielle", en Esprit, juin (1953), donde reflexiona sobre la experiencia de las vías seguidas para implantar una democracia industrial y sus limitaciones.

70GURVITCH, G.: Le Temps présent et l'idée du Droit Social, París, ed.J.Vrin, 1932, págs.101 y sigs.

71 Esta concepción es lo que le aproxima -estrechamente- a la cosmosión del pluralismo jurídico-social y a la noción de democracia colectiva postulada por autores del iussocialismo jurídico como Hugo Sinzheimer, que, sin embargo, era más exigente y contundente de la necesidad del garantismo legal de los derechos precisamente para apoyar al autonomía social de los grupos e impulsar la transformación hacia el socialismo democrático. Sinzheimer incardinaba su teoría pluralista del Derecho Social -donde se combinaba la el dederecho de autodeterminación colectiva de los grupos sociales y la garantía de los derechos sociales fundamentales en la Constitución y en la legislación estatal- en una concepción del Estado Social de Derecho, como la consagrada en la Constitución de la República de Weimar. No se puede desconocer que él fue el artífice directo del artículo 165 de la Constitución de la República de Weimar, en cuyo advenimiento y defensa estuvo especialmente comprometido como juristica crítico del trabajo. Sinzheimer va a vincular la idea del Derecho Social con la constitución democrático-social del trabajo que fue introducida por él mismo en el art. 165 de la Constitución de la República de Weimar de 1919. Por el contrario, Gurvitch no articulo una teoría del Estado social, pero finalmente acabaría comprendiendo por la experiencia que una democracia industrial exige la construcción de un sistema política que la enmarque y la haga efectivamente posible. Véase al respecto, y en el marco de una reflexión sobre sobre el papel central desempeñado por los iussocialista en la construcción del Derecho Social y de la Constitución democrático-social del trabajo, MONEREO PÉREZ, J.L: Fundamentos doctrinales del Derecho Social en España, Madrid, Editorial Trotta, 1999, espec., Cap. 1 ("Los fundamentos doctrinales del derecho social: la contribución del socialismo jurídico"), Capítulo 2 ("La influencia del socialismo jurídico en la cultura jurídica europea entre las dos guerras mundiales"), y sobre todo el capítulo 4 ("Derecho social, socialismo 
El pluralismo de Gurvitch se aproxima a la concepción de Durkheim, para quien toda agregación humana mínimamente estable ostenta capacidad de organizarse jurídicamente 72. Se trata de órdenes de Derecho equivalentes al Derecho estatal, le hacen concurrencia y realizan el principio del pluralismo jurídico. De manera que no sólo en el plano internacional coexisten y se superponen ordenamientos jurídicos diferentes, sino que también el ámbito de los ordenamientos nacionales pueden coexistir sistemas jurídicos diferentes. En esta línea de pensamiento concluye que sólo una revisión fundamental de la teoría de las fuentes del Derecho positivo puede dar una solución satisfactoria a los problemas planteados por el desarrollo actual del Derecho obrero y del Derecho internacional. Es así que se constata la tendencia a una pluralización de esferas jurídicas que conduce a la necesidad de concebir, a costa del Derecho estatal, una multiplicidad de otras fuentes formales del derecho positivo reconocidas equivalentes a la ley; superando de este modo el "fetichismo de la ley"73. Así las adquisiciones del movimiento en favor del Derecho positivo extra-legislativo y libre se afirman como el fundamento igualmente indispensable de doctrinas modernas del Derecho obrero y del Derecho internacional, como su base común, que sólo puede suministrar su justificación74. En realidad, con apoyo en Hugo Sinzheimer, las teorías del "derecho libre" y de "la impotencia de la ley" dan cuenta de que la realidad del derecho vivo está abarcando toda la realidad del derecho social, el cual se libera de la tutela del Derecho estatal, como inversamente las teorías del derecho social han

democrático y constitución jurídica de la clase trabajadora"; "Reforma Social y constitución del trabajo" y "La combinación de status y contrato en la constitución del trabajo"). Para concepción del Gurvitch sobre el espacio de lo político y el papel del Estado, véase MONEREO PÉREZ, J.L.: Pluralismo jurídico y Derecho social: La sociología del Derecho de Gurvitch, Estudio Preliminar a la obra de GURVITCH, G.: Elementos de sociología jurídica, Granada, Editorial Comares (Col. Crítica del Derecho), 2001, págs. XIIICXLVI.

Respecto a la misma posición de Hugo Sinzheimer, véase, entre su abundante producción científica, SINZHEIMER, H.: «Der Wandel im Weltbild des Juristen» («El cambio en la concepción del mundo del jurista»), en Zeits $\neg$ chrift für soziales Recht, año 1 (1928), págs. 2 a 6; SINZHEIMER, H.: "Die Idee des Arbeitsrechts", ArbR, 1923, pp. 721-730 y "Der Kampf um das neue Arbeitsrecht" (1923), en OTTO KAHN-FREUND Y THILO RAMM (ed.): Hugo Sinzheimer. Arbeitsrecht und Rechtssoziologie. Gesammelte Aufsätze und Reden, Europäische Verlagsanstalt, Frankfurt am Main y Köln, 1976, págs. 9199; SINZHEIMER, H.: «El problema del hombre en el Derecho», en SINZHEIMER, H.: Crisis económica $y$ derecho del trabajo. Cinco estudios sobre la problemática humana y conceptual del Derecho del Trabajo, trad. F. Vázquez Mateo, Madrid, MTSS, 1984, págs. 110 y sigs. El vínculo existente entre ambos pensadores iussocialista se hace visible no sólo en sus grandes obras, sino también en sus artículos. Así, respecto a Gurvitch: GURVITCH, G.: "Les syndicats et l' intérêt général", en L' Homme réel, n'. 1, 1934, y GURVITCH, G.: "Le plan et la démocratie industrielle", en L'Homme réal, nº. 12, 1934.

72 Puede consultarse, MONEREO PÉREZ, J.L.: Cuestión social y reforma moral: las 'corporaciones profesionales' en Durkheim, estudio preliminar a DURKHEIM, E.: Lecciones de sociología. Física de las costumbres y del Derecho, trad. Estela Canto, revisión, edición y estudio preliminar a cargo de J.L. Monereo Pérez, Granada, Ed. Comares (Col. Crítica del Derecho), 2006, págs. VII-LI.; MONEREO PÉREZ, J.L.: Razones para actuar: solidaridad orgánica, anomia y cohesión social en el pensamiento de Durkheim, estudio preliminar a DURKHEIM, D.: Sociología y Filosofía, trad. J. M. Bolaño (hijo), revisión, edición, y estudio preliminar a cargo de J. L. Monereo Pérez, Granada, Ed. Comares (Col. Crítica del Derecho), 2006, págs. VII-LXVI.

73Aquí Gurvitch asume como propia la crítica formulada por Gény al formalismo jurídico. Cfr. GÉNY, G.: Método de interpretación y fuentes en Derecho privado positivo, Est.Preliminar sobre "El pensamiento científico jurídico de Gény" (pp. XVII-LXXV), a cargo de J.L.Monereo Pérez, Granada, Ed.Comares (Col. Crítica del Derecho), 2000.

74GURVITCH, G.: Le Temps présent et l'idée du Droit Social, París, ed.J.Vrin, 1932, págs.296-297. 
señalado el dinamismo esencial de este derecho en oposición al estatismo relativo del derecho individual75.

En estas propuestas de reformismo político y iussocial confluyen en Gurvitch diversas tradiciones de pensamiento (marxismo, socialismo democrático, sindicalismo revolucionario, el pensamiento social y jurídico de Proudhon). Su pensamiento es, aquí también, un intento de síntesis dialéctica entre esas culturas anticapitalistas, pero en la que queda realzada con luz propia la influencia siempre persistente de Proudhon, con el cual mantuvo una especial afinidad hasta sus últimos días76. De tal manera que sería imposible concebir su pensamiento sin hacer reclamo de las concepciones de ese pensador. En realidad, como afirmara el propio Georges Gurvitch -coincidiendo en gran medida con Jaurès- la doctrina social moderna es impensable "sin una síntesis del pensamiento de estos hermanos enemigos" (Proudhon, Fichte y Marx)77. Pero es que aparte de estas influencias resulta innegable las influencias existen y son perceptibles de las obras de Karl Marx, Emile Durkheim, Leon Duguit, y de filósofos rusos78.

La influencia de Proudhon se manifiesta en la visión del sistema social como una totalidad inmanente integradora de una multiciplicidad de dimensiones que no es sino la expresión de la riqueza de la experiencia humana. No obstante, las fuerzas colectivas que se mueven en el entramado social no son estáticas, sino dinámicas, en la medida en que el movimiento social está presidido por una continua tensión dialéctica entre las fuerzas sociales existentes79. Agrégese que para Gurvitch las estructuras sociales no son estables, experimentando un movimiento de cambio constante80. Así, los grupos sociales están en lucha permanente alcanzando sólo equilibrios provisionales en una sociedad siempre compleja y contradictoria81. He aquí donde el sistema jurídico encuentra una función típica para resolver los conflictos sociales, de manera que se consiga un equilibrio existente entre las fuerzas sociales. Pero, como en Proudhon, el Derecho no sólo es el surgido del Estado, sino también, e importante en no menor medida, es el derecho social autónomo, sea o no

75GURVITCH, G.: Le Temps présent et l'idée du Droit Social, París, ed.J.Vrin, 1932, pág.298.

76Véase GURVITCH, G.: L'Idée du Droit Social. Notion et Système du Droit Social, París, Sirey, 1932 (reimpresión alemana de la edición de París de 1932, Scientia Verlag Aalen-1972), págs.327 y sigs.; y su pequeña monografía posterior GURVITCH, G.: Proudhon. Su vida, su obra, su filosofía, trad.J.Marfá, Madrid, Ed.Guadarrama, 1974. En su opinión Proudhon es "el más grande pensador social francés". Cfr. GURVITCH, G.: La Déclaration des Droits Sociaux, New York, Editions de la Maison Française, 1944 (ed. francesa, París, Librairie Philophique J.Vrin, 1946), pág.22.

77 GURVITCH, G.: «Mon itinéraire intellectuel ou l'exclu de la horde», in Georges BALANDIER, Georges Gurvitch, sa vie, son oeuvre, Paris, PUF, 1972.

78 ANTONOV, M.: "La théorie du droit de Georges Gurvitch et ses origins philosophiques russes", en Droit et société, núm.94 (2016/3), pages 503 à 512. https://www.cairn.info/revue-droit-et-societe-2016-3page-503.htm. El autor subraya la influencia importante de la tradición jurídica Rusa y en general de pensamiento del país en el que se formó. Por ejemplo, Léon Petrazycki, Mikolai Lossky.

79Véase GURVITCH, G.: Proudhon. Su vida, su obra, su filosofía, trad.J.Marfá, Madrid, Ed.Guadarrama, 1974, pág.42.

80Véase GURVITCH, G.: "Le concept de la structure sociale", vol.19 (1955).

81De ahí también su visión de la dialéctica, influenciada tanto por las concepciones de Proudhon como las de Marx. Véase su monografía sobre la dialéctica, GURVITCH, G.: Dialéctica y Sociología, trad. J.R.Capella, Madrid, $1^{\text {a }}$ ed., 1969; $2^{\mathrm{a}}$ ed.1971; GURVITCH, G. (Dir.): "Groupements particuliers et classes sociales", en Traité de sociologie, t.I., $4^{\mathrm{a}}$ ed., París, PUF, 1962, págs.185 y sigs. 
espontáneo (éste adquiere un papel más importante en Proudhon, como por cierto -dejando a salvo las evidentes perspectivas distintas- sucederá también con Ehrlich82-). Por ello mismo expresará Gurvitch que "se debe atribuir a Proudhon el que haya enriquecido la realidad social e insistido sobre el hecho de que ésta abarca no solo las fuerzas colectivas, sino igualmente las reglamentaciones sociales, nacidas de estas fuerzas, y que estos dos niveles se encuentran en relaciones dialécticas múltiples, de dónde su complejidad"83. De él también extrae la necesidad de elaborar una nueva declaración de derechos con una técnica pluralista, que partiría positivamente de la limitación recíproca de los grupos autónomos y de los conjuntos equivalentes e iguales en Derecho, para defender la libertad humana en una época de desarrollo de organizaciones de larga envergadura. Pero igualmente parte de la concepción de Proudhon según la cual los derechos sociales deben emanar de los grupos autónomos y de los individuos en tanto que centros activos de la vida jurídica, capaces de realizarlos y de defenderlos por sus acciones propias en toda libertad84.

Pero los fundamentos de su doctrina política y social son más amplios y variados dentro de una tradición socialista que abarca desde el socialismo utópico (sobre todo Saint-Simon85) al marxismo. De Marx realza Gurvitch su visión humanista del hombre en la sociedad moderna y la aspiración a que éste obtenga una plena libertad y un pleno desarrollo de su personalidad en todas las facetas que hacen del ser humano un hombre total, superando su contemplación en una de las facetas aisladas (como la de productor o consumidor). Realza, ante todo, en la concepción del joven Marx lo que califica de "humanismo realista dialéctico". Considera, en efecto, "que la expresión que determina mejor su orientación dialéctica es la de dialéctica del humanismo realista, porque insiste sobre en el hecho de que todo lo que procede de la realidad humana en tanto que movimiento real y en tanto que toma de conciencia de este movimiento es dialéctico"86. La apropiación del hombre de todas sus facetas (liberándole de las situaciones de alienación), al igual que la superación de las diferencias de procedencia de clase social, es, en efecto, una de las características de la antropología de Marx. Pero no es sólo su antropología lo que interesa a Gurvitch, sino también su método de explicación sociológica e histórica. La misma idea de análisis totalizador de la sociedad, de fenómeno social total se formuló por M. Mauss, pero deriva en buena parte del pensamiento de Marx, completado por las aportaciones de Marcel Mauss.

Este concepto, "fenómeno social total", remite a la sociedad tal como es dada en la experiencia inmediata. Para Gurvitch, los fenómenos sociales totales son totalidades reales en marcha, en movimiento sin detención. Son el elemento dinámico de la realidad social, el

82Véase EHRLICH, E.: I fondamenti della sociologia del diritto, Milano, Giufrè, 1976; y la crítica de Gurvitch a su pensamiento, en GURVITCH, G.: Elementos de sociología jurídica, cit., págs.117 y sigs.,

83GURVITCH, G.: Proudhon. Su vida, su obra, su filosofía, trad. J.Marfá, Madrid, Eds.Guadarrama, 1974. págs.38-39.

84GURVITCH, G.: La Déclaration des Droits Sociaux, New York, Editions de la Maison Française, 1944 (ed., francesa, París, Librairie Philophique J.Vrin, 1946), pág.23.

85SAINT-SIMON, C.H.DE.: La physiologie sociale, ed. a cargo de G.Gurvitch, con Introducción y Notas suyas, París, PUF, 1965.

86GURVITCH, G.: Dialéctica y Sociología, trad.J.R.Capella, Madrid, 1ª ed., 1969; $2^{\text {a }}$ ed.1971, págs.165 y sigs. 
surco de las erupciones de ésta, comprendidos en un movimiento de flujo y reflujo, reservas de ímpetu de los actos y los esfuerzos colectivos que deben perpetuamente luchar contra obstáculos internos y externos y por medio de los cuales los Nosotros, los grupos y las sociedades se crean y se modifican a sí mismos. Los Nosotros (masas, comunidades y comuniones), los grupos particulares y las clases sociales son también fenómenos sociales totales. La riqueza de los fenómenos sociales sólo puede ser comprendida en su plenitud al darse cuenta que la tendencia a la preeminencia de lo global sobre lo parcial admite gradaciones casi infinitas y que un drama perpetuo se desarrolla entre los fenómenos sociales totales, parciales y globales, los cuales pueden a la vez ser complementarios, estar en situación de implicación mutua, de ambigüedad, de polarización y de reciprocidad de perspectivas87. La idea de totalidad exige un método de análisis globalizador (nótese que para él el método de la sociología como ciencia de la sociedad "consiste en la toma de consideración del 'conjunto', en la tipología discontinuista y, por lo tanto, en el indispensable recurso a la dialéctica"), que eluda toda fácil simplificación respecto a la variedad de los factores que concurren en la configuración de los fenómenos sociales88. Defiende que sin una dialéctica crítica de la sociedad no es posible aprehender el objeto de la sociología89.

Él propugnará una dialéctica empírico realista, siendo ese "hyper-empirismo dialéctico" el método más adecuado para dar cuenta de la "manifiesta pluridimensionalidad de todo lo real cognoscible"90. Su método dialéctico implicaba una lucha permanente contra todo dogmatismo, toda preconcepción, toda concepción apriorística91. Por tanto, en coherencia, definirá la sociología como "la tipología cualitativa y discontinuista -fundada en la dialéctica- de los fenómenos sociales totales estructurales, estructurables y estructurados que ella estudia a la vez en todos los planos en profundidad, en todas las escalas y en todos los sectores, a fin de seguir sus movimientos de estructuración, desestructuración, reestructuración y dispersión, hallando su explicación en colaboración con la historia". Y añade, con mayor concisión que: "si quisieramos llegar a una fórmula más breve, se podría decir que la sociología es una ciencia que estudia los fenómenos sociales totales en el conjunto de sus aspectos y de su movimiento, captándolos en tipos dialectizados microsociales, grupales y globales en proceso de hacerse y deshacerse"92. La sociología

87Véase, GURVITCH, G.: "Les phenomènes sociaux totaux et la science de l'homme", en Esprit, 24, Mars., 1956, págs.381-392; GURVITCH, G. (Dir.): Traité de sociologie, t.I., $4^{\mathrm{a}}$ ed., París, PUF, 1962, sobre todo, $2^{\mathrm{a}}$ sección ("Problèmes de sociologie générale"), págs.155 y sigs.

88GURVITCH, G. (Dir.): Traité de sociologie, t.I.,4a ed., París, PUF, 1962, Sección 1ª "Introducción", Cap. $1^{\circ}$ ("Objeto y método de la sociología"), pág.3

89Véase GURVITCH, G.: Dialéctica y Sociología, trad. J.R.Capella, Madrid, $1^{\mathrm{a}}$ ed., 1969; $2^{\mathrm{a}}$ ed.1971; GURVITCH, G.: "Objet et méthode de la sociologie", en Traité de sociologie, t.II., $4^{\mathrm{a}}$ ed., París, PUF, 1962, págs.3 y sigs.

90GURVITCH, G.: "Hyper-empirisme dialectique. Ses aplications en sociologie", C.I.S., XV, 1953, págs.3 a 33. Puede consultarse BOSSERMAN, PH.: Dialectical sociology, an analysis of the sociology of Georges Gurvitch, Boston, Porter Sargent, 1968.

91En este sentido CAZENEUVE, J.: "La sociologie de G. Gurvitch", en Revue français de sociologie, VII1966, pág.12.

92GURVITCH, G. (Dir.): Traité de sociologie, t.I., $4^{\mathrm{a}}$ ed., París, PUF, 1962, pág.27. 
utiliza, bajo el influjo del pensamiento de Max Weber93, el método tipológico, basado en la formación de tipos específicos o modelos tipo-ideales los cuales permiten abarcar y comprender la complejidad de la realidad social94. Asimismo, se sirve de ese método específico, el "hiper-empirismo dialéctico", apto para captar en cada momento el cambiante movimiento de lo social95, precisamente porque es capaz de modificar constantemente sus propias bases en atención a los cambios del entorno de la realidad social. Para Gurvitch es necesaria la demolición perpetua de los conceptos, los cuales se hallan en continuo

93Véase GURVITCH, G.: Elementos de sociología jurídica, cit., págs.19 y sigs. Véase, en una perspectiva de conjunto, MONEREO PÉREZ, J.L.: Modernización y racionalización del poder y del Derecho. La crítica de la razón instrumental en Max Weber, estudio preliminar a WEBER, M.: Política y Ciencia y otros ensayos de sociología, trad. C. Correas, revisión, edición y estudio preliminar a cargo de J.L. Monereo Pérez, Granada, Ed. Comares (Col. Crítica del Derecho), 2013, págs. IX-LXII; MONEREO PÉREZ, J.L.: Modernidad y Capitalismo. Max Weber y los dilemas de la Teoría Política y Jurídica, Barcelona, Ediciones de Intervención Cultural/El Viejo Topo, 2013.

94Podrá decir que "el método tipológico es un lugar de encuentro, o más bien, de entre-cruzamiento, del método individualizante y del método generalizante: se generaliza aquí, en un cierto límite, para mejor resaltar la singularidad del tipo que, sin embargo, puede reproducirse, lo que es excluido por los hechos históricos; se individualiza el tipo, pero igualmente en un cierto límite, porque previamente se han generalizado sus elementos componentes, trocándose, por ello mismo, aplicable a muchos casos análogos. Lo que se ha excluido es el pasaje continuo entre los diferentes tipos cualitativos así construidos". Cfr. GURVITCH, G.: Essais de Sociologie, París, ed. du Recuil Sirey, 1938, págs.11-12.

95Sobre la discontinuidad de lo social en el pensamiento de Gurvitch, véase BRAUDEL, F.: "Georges Gurvitch ou la discontinuité du social", Anales, Juill.Sept., 1953, págs.347 a 361. En su autobiografía intelectual Gurvich indicaría con contundencia que: "Lo que mejor designa mi método sociológico es el hiperempirismo dialéctico (Cfr. mi artículo con este mismo título en los Cahiers Internationaux de Sociologie, 1953), una vez llevados al límite mi relativismo y mi realismo en sociología. Las complementariedades, las implicaciones mutuas, las ambigüedades, las polarizaciones y las reciprocidades de perspectivas entre los tipos microsociológicos, los tipos de agrupamientos y de clases sociales, los tipos de sociedades globales; entre los niveles en profundidad de la realidad social, cuyas jerarquías varían con cada uno de los tipos de la estructura parcial o global; entre los fenómenos sociales globales, los elementos estructurales, las estructuras y las organizaciones; entre sociología general y ramas particulares de la sociología; entre sociología, historia y etnología; en fin, dan una idea de este método. Su finalidad es llegar a una explicación en sociología, explicación que, cuando deviene causal, se junta a la explicación histórica. Uno de los secretos en la unión entre teoría e investigación empírica en sociología reside, al lado de la experimentación propiamente dicha y de la perpetua puesta al día de las hipótesis del trabajo, en los muy apreciados materiales que la historia brinda a la sociología. Por otra parte, la historia en sí misma necesita en su inicio la tipología sociológica y su estudio de las estructuras (Cfr. mi estudio "Continuidad y discontinuidad en sociología y en historia", en los Annales, 1957, y mi artículo "La crisis de la explicación en sociología" en los Cahiers Internationaux de Sociologie, 1956. Retomé el mismo tema en mi curso "La multiplicité des temps sociaux",1958). Aquí se sitúa mi rencuentro con Marx después de largos años de separación... El mismo hiper-empirismo dialéctico condujo mis investigaciones sobre los Determinismos sociales y la libertad humana (1955). Intenté mostrar cómo determinismos y libertad pueden interpenetrarse y estudié sociológicamente los caminos de la libertad a través de los distintos cuadros sociales. El pluralismo de los determinismos sociales siempre parciales y su unificación relativa (mediante luchas y esfuerzos sin fin), en el determinismo sociológico, que cambia de fórmula para cada tipo de sociedad global, dejan un amplio lugar a la intervención de la libertad humana, individual y colectiva, en la vida social. En esta misma obra planteé el problema de la multiplicidad de los tiempos sociales, problema al que acabo de dedicar mi curso público en la Sorbona durante el actual año escolar 1957-1958 (En él muestro cómo los tiempos sociales se unifican e interpenentran en las jerarquías variables según las estructuras de las sociedades globales y de sus tipos)". Cfr. Cfr. GURVITCH, G.: "Mon itinéraire intellectuel ou l' exclu de la horde", en Lettres Nouvelles, núm.6 (1958), págs. 65 a 83. Publicado después en L' Homme et la Société, I, 1966; y en la recopilación de DELEDALLE, G. y HUISMAN, D.: Les philosophes français d' aujourd' hui pas euxmêmes. Autobiografhie de la philosophie française contemporaine, París, C.D.U., 1963, págs.100 a 116; igualmente recogido en DUVIGNAUD, J.: Georges Gurvitch, París, Éditions Seghers, 1969, págs.79 a 98. 
movimiento y contingencia. Por ello su perspectiva científica no es propiamente dogmática, ya que está sometida a un "super-relativismo", frustrando toda idealización, sublimación o dogmatización consciente o inconsciente de coyunturas presentes, pasadas o futuras, impidiendo toda fácil solución.

Por otra parte, manifiesta la pluridimensionalidad de todo lo real cognoscible 96 . Y es que para Gurvitch no pueden formularse leyes causales, leyes evolutivas ni leyes funcionales en el ámbito de la sociología. No existen determinismos irresistibles más allá de los enunciados de probabilidad estadísticos. Sin perjuicio de que sí sea posible establecer tendencias uniformes en diversas manifestaciones sociales. Es de significar que el concepto de libertad es utilizado para poner a prueba formas sociológicas de determinismo97, sobre un fondo subyacente de una "sociología en profundidad" de base esencialmente fenomenológica98, siendo así que ninguno de los ámbitos o niveles de profundidad es capaz de suprimir la libertad humana, toda vez que actúan entre sí y se limitan mutuamente99. Entiende que la existencia de determinaciones (de orden económico, sociológico, etcétera) de la vida humana no son siempre ineludibles, fatales en su ocurrencia. No participa de una concepción fatalista de la existencia humana, ya que para él en el movimiento de continuidad y discontinuidad de los hechos puede mediar la intervención de la persona, pudiendo producirse la ruptura de los nexos de causalidad. Otro tanto ocurre respecto de la dimensión colectiva del hombre, donde Gurvitch ve en la evolución histórica una lógica dialéctica de continuidad y discontinuidad, apreciendo la realidad histórica en toda su complejidad intrínseca. Para Guvitch la libertad está condicionada por un cúmulo muy diverso de factores, pero se muestra más optimista que Max Weber, el cual creyó en que se produciría la neutralización de la voluntad humana a consecuencia del creciente proceso de racionalización jurídica y económica de las sociedades altamente desarrolladas 100.

Por otra parte, entiende Gurvitch que desde que la sociología renununció a su pretensión incial de establecer leyes generales del desarrollo de la sociedad, desde que ha abandonado su tendencia a substituir a la Filosofía de la Historia, o aplazado esta tarea para una época

96GURVITCH, G.: "Hyper-empirisme dialectique. Ses aplications en sociologie", en C.I.S., XV, 1953, págs. 3 a 33, en particular págs. 11 y sigs.

97Consúltese GURVITCH, G.: "Les règles de l'explication en sociologie. Les variations des formules du déterminisme sociologique", en Traité de sociologie, t.II., $4^{\mathrm{a}}$ ed., París, PUF, 1962, págs.236 y sigs.

98Véase GURVITCH, G.: "Sociologie en profondeur", en Traité de sociologie, t.I., $4^{\text {a }}$ ed., París, PUF, 1962, págs.157 y sigs.; GURVITCH, G.: Elementos de sociología jurídica, cit., cap.II, Segunda Sección.

99En este sentido GURVITCH, G.: Déterminismes sociaux et liberté humaine, $2^{\mathrm{a}}$ ed., París, PUF, 1963, passim. Para Gurvitch "la libertad humana, que se verifica tanto en las experiencias colectivas como en las individuales, consiste en una acción voluntaria, espontánea y clarividente -innovadora, inventiva y creadora-, que, guiada por sus propias luces surge durante el mismo acto, provoca la interpenetración del motor, del motivo y de la contigencia, esforzándose para pasar, derribar, romper todos los obstáculos, y para modficar, superar y recrear todas las situaciones". Téngase en cuenta que según Gurvitch, existen diversos grados de la libertad humana: la libertad que dispone según las preferencias subjetivas; la libertad que es relización innovadora; la libertad de elección; la libertad de invención; la libertad de decisión; y, por último, la libertad de creación (Ibid., pág. 82).

100 Véase MONEREO PÉREZ, J.L.: Modernidad y capitalismo. Max Weber y los dilemas de la teoría política y jurídica, Barcelona, Ediciones de Intervención Cultural/El Viejo Topo, 2013, espec., págs. 110 y sigs. 
más lejana, varios de los más emientes sociólogos modernos han consagrado con preferencia sus esfuerzos al estudio de los tipos sociales cualitativos. Estos tipos cualitativos buscados en sociología se oponen, tanto a los hechos absolutamente singulares construídos por los historiadores, como a los hechos más o menos generales construídos por los representantes de las ciencias de la naturaleza. El método tipológico es un punto de encuentro, o más bien de entrecruzamiento, del método individualizador y del método generalizador, es decir, se genealiza aquí, dentro de cierto límite, para poner más de relieve la signularidad del tip que, sin embargo, puede reproducirse, cosa que está excluída para los hechos históricos; se individualiza el tipo, aunque también un cierto límite, pues previamente se han generalizado sus elementos constitutivos que lo componen haciéndolopor eso mismo aplicable a varios casos análogos. Lo que está excluído es el paso continuo entre los diferentes tipos cualitativos así construídos. Es de subrayar, al respecto, que según Gurvitch la discontinuidad y el límite de generalización en la investigación de los tipos sociales están dados por la necesidad de recurrir para establecerlos a la comprensión intepretativa de las singularidades internas de las conductas y de los símbolos colectivos101.

En esa línea de pensamiento procedió a construir la sociología del conocimiento, partiendo de que éste es un hecho social inscrito en un fenómeno social total102. El conocimiento es efectivamente sociológico en cuanto que es resultado de la acción de los actores sociales y de su adscripción a unos marcos sociales específicos. En realidad, cabe hacer referencia a "conocimientos" en plural, dependientes de la variabilidad de la experiencia humana, los individuos y grupos sociales de pertenencia o de encuadramiento. Por ello, la sociología del conocimiento está intensamente implicada en la realidad social y en el engranaje de sus estructuras, y asimismo resulta condicionada por el marco social de referencia en que se produce103.

Con base a este método, Gurvitch distingue entre diversos tipos microsociológicos atendiendo al criterio de unión y contraposición espontáneas en cuanto formas de sociabilidad diversas de las "organizadas"104. Nuestro autor establece una clasificación

101 GURVITCH, G.: Las formas de sociabilidad, trad. Francisco Ayala, Buenos Aires, Ed.Losada, 1941, Introducción, págs. 11 y sigs. Observa que esta sociología tipológica cuyo problema fue ya casi presentido por Durkheim (cuyo método fue precisado por Max Weber y cuyas más seguras adquisiones -en el campo especial de la mentalidad arcáica- fueron aportadas por Lévy-Brunhl), encuentra su aplicación en todas las disciplinas sociológicas particulares (Ibid., pág. 12).

102Para Gurvitch la sociología del conocimiento remite al "estudio de ciertas correlaciones funcionales que pueden establecerse entre los distintos géneros, las diferentes acentuaciones de las formas de estos géneros, los diferentes sistemas (jerarquías de estos géneros) de conocimiento por una parte y los marcos sociales por otra, es decir, las sociedades globales, las clases sociales, grupos particulares y manifestaciones diversas de la sociabilidad (elementos microsociales). Entre los marcos sociales, las estructuras sociales parciales y, sobre todo, globales constituyen el núcleo de estos estudios, facilitados aquí por el papel que el saber puede jugar junto a las otras obras de la civilización y reglamentaciones sociales en el armazón de una estructura, ese equilibrio precario de jerarquías múltiples". Cfr. GURVITCH, G.: Los marcos sociales del conocimiento, Caracas (Venezuela), Monte Ávila Editores, 1969, cap.II ("Definición de la sociología del conocimiento), págs.25-26.

103Véase GURVITCH, G.: Los marcos sociales del conocimiento, Caracas (Venezuela), Monte Ávila Editores, 1969, cap. III, págs. 22 y sigs.

104Gurvitch construye una compleja clasificación de las diversas formas de sociabilidad, aunque se trata de 
operativa cuya secuencia abreviada es la siguiente: sociabilidad espontánea por interpenetración, participación y fusión parcial en los "Nosotros", y sociabilidad espontánea por oposición parcial y unión mutua entre "Yo", "Tú", "Él", "Ellos", constituyendo las "relaciones con el otro". En la sociabilidad por fusión parcial en los Nosotros los grados de intensidad (de la sociabilidad por interpenetración) son la Masa, la Comunidad y la Comunión, siendo éste último grado el de mayor intensidad. Los nosotros activos pueden servir a un interés general o a uno particular dentro de la sociedad pluralista105, reflejando una forma integrada de sociabilidad106. En el pensamiento de Gurvitch la comunión es el grado más elevado, en intensidad y en profundidad, de la sociabilidad por interpenetración y fusión parcial. Es, así, la actualidad de la intuición colectiva llevada a su fuerza suprema; es el "Nosotros" más profundo. En la sociabilidad-comunión la interpenetración de las conciencias y de las conductas están en su máximum y por ello su fusión parcial engloba las aspiraciones más profundas de los “yo" que participan en la unión. En planteamiento general la comunión corresponde normalmente a éxtasis colectivos, que no suelen ser sino de corta duración y, por tanto, contigentes. De ahí que la comunión, en la vida social corriente, no es sino una virtualidad latente que se actualiza en raros momentos. Existen, no obstante, unidades colectivas reales de carácter excepcional en el seno de las cuales la comunión está siempre despierta y en que predomina normalmente sobre los elementos de masa y de comunidad. Se trata de las iglesias, las sectas religiosas, las cofradías mágicas, etcétera; agrupaciones que encuentran su base en intuiciones mísicas, muy distintas de todas las demás intuiciones colectivas107. Ahora bien, piensa Gurvitch que existe una imposibilidad de establecer una jerarquía entre masa, comunidad y comunión. En efecto, es generalmente imposible -afirma- establecer una jerarquía precisa entre las distintas formas de sociabilidad, sea desde el punto de vista sociológico o desde el punto de vista moral. Por lo demás, esta

una enumeración un tanto excesiva (ciento sesenta y dos tipos de sociabilidad). Dicha clasificación no supone una excesiva aportación en el plano dogmático y sistemático, pero se justifica por el intento de disección de la realidad, constituyendo un penetrante ejercicio de técnica de definición.

105 GURVITCH, G.: La vocación actual de la sociología. Hacia una Sociología diferencial (1950), trad.P.González Casanova, Max Aub y S.de la Fuente, México, F.C.E., 1953, págs. 96 y sigs. (sobre las formas de sociabilidad y su clasificación pluralista), y págs. 181 y sigs. (sobre el análisis crítico de algunas clasisificaicones de las formas de sociabilidad).

106 Resulta de gran interés confrontar esta concepción con la concepción de otro socialista democrático como TÖNNIES, F.: Comunidad y asociación, trad. José-Francisco Ivars, revisión técnica de J.L. Monereo Pérez, edición y estudio preliminar, "La interpretación de la Modernidad en Tönnies: "Comunidad" y "Sociedad-Asociación” en el desarrollo histórico" (pp. XI-XLIV), a cargo de J. L. Monereo Pérez, Granada, Ed. Comares (Col. Crítica del Derecho), 2009, págs. 9 y sigs.; TÖNNIES, F.: Principios de sociología, trad. Vicente Lloréns, revisión, edición y estudio preliminar, "La sociología como crítica social: la aportación de Ferdinand Tönnies” (pp. XV-XLVI), a cargo de J.L. Monereo Pérez, Granada, Ed. Comares (Col. Crítica del Derecho), Granada, 2009, págs. 33 y sigs. Asimismo -más allá de las diferencias de pensamiento crítico entre ellos- comparten la idea de concebir la democracia como instrumento de transformación social (Ibid., págs. 237 y sigs.). Aunque, ciertamente, el propio Gurvitch realiza una crítica matizada de la concepción de Tönnies de las formas de sociabilidad, así como la de Scheler. Cfr. GURVITCH, G.: La vocación actual de la sociología. Hacia una Sociología diferencial (1950), trad. P.González Casanova, Max Aub y S.de la Fuente, México, F.C.E., 1953, págs. 203 y sigs.; y antes de la teoría de las diversas formas de solidaridad de Durkheim, Ibid., págs. 181 y sigs. Asimismo, anteriormente, GURVITCH, G.: Las formas de sociabilidad, trad. Francisco Ayala, Buenos Aires, Ed.Losada, 1941, págs. 107 y sigs.

107 GURVITCH, G.: Las formas de sociabilidad, trad. Francisco Ayala, Buenos Aires, Ed.Losada, 1941, págs. 41 y sigs. 
imposibilidad se aplica igualmente a las relaciones entre los tres grados de intesidad de la sociabilidad por interpenetración y fusión parical (masa, comunidad y comunión). Desde el punto de vista sociológico la comprobación de que la masa ejerce más presión que la comunidad o la comunión no puede servir de criterio de apreciación, pues, evidentemente, no corresponde a la sociología decidir si una presión más o menos fuerte es un bien o un mal. El papel mismo de la presión en la cohesión social, combinado con el de la intesidad y el del volumen (extensión), es completamente variable y depende de circunstancias concretas108. Todo lo que puede decirse es que la presencia virtual en el seno de cada grupo de estas tres formas de sociabilidad en concurrencia es un factor esencial de su equilibrio movible. Pero es de realzar que para él el refuerzo del elemento comunión en una sociedad democrática avanzada puede contribuir al desarrollo social igualitario. Las estructuras políticas y jurídicas organizadas según el principio de colaboración y la participación activa se desarrollan más fácilmente que todas las demás en democracias descentralizadas, federales, pluralistas109. Desde el punto de vista moral, fundándose sobre consideraciones de valor, es igualmente imposible una jerarquización de las relaciones entre mas, comunidad y comunión. Por lo pronto, en cada una de estas tres especies de unión, cuando se trata de intuiciones colectivas de valores, éstas pueden ser tanto negativas como positivas. Por otra parte, también considera que es imposible privilegiar moralmente la comunicación y la comunidad con relación a la masa110.

Según Gurvitch toda "relación social" y todo "contacto social", en tanto que son "sociales" presuponen un "Nosotros", una fusión o interpetración virtuales y son imposibles sin ella. La interdependencia, en tanto que no es puramente mecánica y proveniente de la física presupone la interpenetración, los contactos y las convergencias de las conciencias más o menos cerradas, y sus posibles aberturas aunque sólo sean latentes. Para él esto es importante y no sólo por evitar interpretaciones puramente cuantitativas y unilateralmente behavioristas, sino también para ensanchar el dominio de sus investigaciones -pasando de las relaciones interpersonales de los "Nosotros" en sus tres grados de intensidad: Masa, Comunidad y Comunión-, para precisar algunos de los conceptos fundamentales (tales como el "átomo social" y el grupo social) y hasta para elaborar ciertas nuevas técnicas de investigación sociológica111.

108 Retégase la diferencia de enfoques sobre las masas (y la era de las masas), por ejemplo, con LE BON, G.: Psicología de las multitudes, trad. J.M. Navarro de Palencia, revisión de J.L. Monereo Pérez, edición y estudio preliminar, "La Era de las masas: El pensamiento socio-político de Gustave Le Bon" (pp. XIIILXXVII), a cargo de J.L. Monereo Pérez, Granada, Ed. Comares (Col. Crítica del Derecho), 2012; y SOREL, G.: Reflexiones sobre la violencia, Versión castellana por Augusto Vivero, revisión técnica, edición y estudio preliminar "Teoría e ideología del sindicalismo en Georges Sorel" (pp. XI-LXIV), a cargo de J.L. Monereo Pérez, Granada, Ed. Comares (Col. Crítica del Derecho), 2011.

109 GURVITCH, G.: Las formas de sociabilidad, trad. Francisco Ayala, Buenos Aires, Ed.Losada, 1941, págs. 54 y sigs.; GURVITCH, G.:"Le Principe démocratique et la Démocratie future", en GURVITCH, G.: L' Expérience juridique et la philosophie pluraliste du Droit, Editions A. Pedone, 1935, págs. 254 y sigs. 110 GURVITCH, G.: Las formas de sociabilidad, trad. Francisco Ayala, Buenos Aires, Ed.Losada, 1941, págs. 54-57.

111 GURVITCH, G.: La vocación actual de la sociología. Hacia una Sociología diferencial (1950), trad. P.González Casanova, Max Aub y S.de la Fuente, México, F.C.E., 1953, págs.181 y sigs., y 224 y sigs.; 
Estos tipos sociológicos ponen de manifiesto el carácter complejo de la estructura social1 12 en la que existen distintas formas de sociabilidad, estratos, grupos y clases sociales; pudiendo aspirarse todo lo más a establecer un equilibrio precario de jerarquías múltiples113. En esta perspectiva analítica, Gurvitch presta una singular atención a la delimitación y a la tipología de los grupos sociales. Los grupos particulares constituyen manifestaciones de la sociabilidad, y constituyen marcos sociales estructurados o al menos estructurables. De manera que todo grupo es un microcosmos de manifestaciones de la sociabilidad, a la par que toda sociedad constituye un macrocosmos de grupos particulares, donde la unidad de la sociedad global presupone la cohesión interna de los distintos grupos funcionales que la integran. Con todo, Gurvitch define el grupo particular como "una unidad colectiva real, pero parcial, directamente observable y fundada en actitudes colectivas 114 continuas y activas, que tienen que realizar una labor común, unidad de actitudes, de obras y de conductas, que constituye un marco social estructurable, que tiende hacia una cohesión relativa de las manifestaciones de la sociabilidad"115. Cada grupo particular presenta sus propias formas colectivas de manifestación específica, las cuales reflejan la sociabilidad activa (conductas, actitudes, los nosotros, la masa, la comunidad, la comunión, etc.) como principio constitutivo de su estructuración interna. Tales manifestaciones son en sí mismas fenómenos sociales totales.

En realidad, las manifestaciones de la sociabilidad son, como los grupos y las sociedades globales, marcos sociales reales. Para Gurvitch todo grupo es un microcosmos de manifestaciones de la sociabilidad y toda sociedad global un marcrocosmos de grupos particulares. Éstos constituyen una unidad múltiple, donde existe una unidad en la pluralidad. Del mismo modo, la unidad de la sociedad global por relación a la multitud de grupos particulares que interactúan se afirma por el predominio acordado a la nación sobre

GURVITCH, G.: Las formas de sociabilidad, trad. Francisco Ayala, Buenos Aires, Ed.Losada, 1941, págs. 50 y sigs.

112Gurvitch nos propone una definición caracterizadora -aunque un tanto excesiva por su extensión- de la estructura social: "Toda estructura social -escribe- es un equilibrio precario, reestablecido constantemente por un esfuerzo renovado, entre una multiplicidad de jerarquía en el seno de un fenómeno social de carácter macrosociológico, del cual ella no representa más que un sector o aspecto: equilibrio entre jerarquías específicas de "paliers" en profundidad, manifestaciones de la sociabilidad, reglamentaciones sociales, temporalidades, modos de división del trabajo y de la acumulación y, llegado el caso, grupos funcionales, clases y sus organizaciones; este equilibrio de jerarquías múltiples está montado y cimentado en particular por modelos, signos, símbolos, roles sociales regulares y habituales, valores e ideas; en una palabra, por las obras de civilización que son propias a esas estructuras y, si éstas son globales, por una civilización entera que las desborda y en la cual ellas participan a la vez como fuerzas creadoras y como beneficiarias". Cfr. GURVITCH, G.: La Vocation actuelle de la Sociologie, cit., pág.445.

113En este sentido GURVITCH, G.: La Vocation actuelle de la sociologie: vers une sociologie différentielle, vol.I, PUF, 1963, cap.VI, III, pág.445.

114Las actitudes colectivas son, según Gurvitch, conjuntos o configuraciones ("Gestalt") sociales, que explican simultáneamente una mentalidad, actos de preferencia y de rechazo, predisposiciones hacia determinadas conductas y reacciones, y, en fin, tendencias a asegurar determinadas funciones. Cfr. GURVITCH, G.: La Vocation actuelle de la sociologie: vers une sociologie différentielle, vol.I, PUF, 1963 (Trad. La vocación actual de la sociología, trad.P.González Casanova, Max Aub y S.de la Fuente, México, F.C.E., 1953).

115Véase GURVITCH, G.: La Vocation actuelle de la sociologie: vers une sociologie différentielle, vol.I, PUF, 1963, Cap.V, I.1., págs. 284-285. 
sus segmentos y se expresa en una jerarquía de grupos funcionales cuya relativa estabilidad representa uno de los elementos de apoyo de la estructura social global, concebida como un todo al mismo tiempo único y diverso116. Esta problemática de las manifestaciones de la sociabilidad, elementos componentes de toda unidad colectiva real, es para Gurvitch, "objeto esencial de la "microfísica social" o, más precisamente, de la microsociología", que es preciso evitar cuidadosamente el identificarlo con los problemas de la "macrofísica social""117.

Con esa configuración de los grupos particulares Gurvitch procede a establecer una clasificación atendiendo a diversos criterios. En función del contenido (grupos funcionales; grupos multifuncionales; grupos suprafuncionales), envergadura, número de participantes o tamaño (grupos reducidos; grupos medianos; grupos externos), duración (grupos temporales; grupos durables; grupos permanentes), ritmo (grupos de cadencia lenta; grupos de cadencia mediana; grupos de cadencia precipitada), medida de dispersión (grupos a distancia; grupos de contactos artificiales; grupos que se reúnen periódicamente; grupos permanentes), base de formación (grupos de hecho; grupos voluntarios; grupos impuestos), modo de acceso (grupos abiertos; grupos de acceso condicional; grupos cerrados), grados de exteriorización (grupos inorganizados no estructurados; grupos inorganizados estructurados; grupos parcialmente organizados; grupos completamente organizados), funciones (grupos de parentesco; grupos de afinidad fraternal; grupos de localidad; grupos de actividad económica; grupos intermedios entre fraternal y actividad económica; grupos de actividad no lucrativa; grupos místicos-extáticos), orientación (grupos de división; grupos de unión), modos de penetración de la sociedad global (grupos refractarios; grupos más o menos sometidos; grupos enteramente sometidos), grado de compatibilidad entre grupos (grupos enteramente compatibles; grupos parcialmente compatibles; grupos incompatibles; grupos exclusivos), modo de imposición (grupos de imposición incondicional; grupos de imposición condicional), principio de organización (grupos de dominación, grupos de colaboración), y, en fin, grado de unidad (grupos unitarios, grupos federados, grupos confederados)118. Determinados grupos son capaces de generar su propio Derecho, tienen, en términos generales, capacidad respectiva para engendrar ordenamientos jurídicos. Pero, es evidente, que no todos los grupos son igualmente favorables por su estructura a la constitución de cuadros jurídicos. Se requiere, de ordinario, una mínima estabilidad, una cierta organización siquiera sea temporal y cohesión interna, tanto funcional como puramente ideológica. Por otra parte, la misma estructura interna de los ordenamientos jurídicos varía evidentemente según los caracteres de los grupos que los han engendrado119.

116Cfr.GURVITCH, G.: La Vocation actuelle de la sociologie, vol.I, cit., págs. 284-285.

117GURVITCH, G.: La Vocation actuelle de la sociologie, vol.I, cit., pág.121.

118Para la estructuración técnica de los grupos particulares, véase GURVITCH, G.: "Groupements particuliers et classes sociales", en Traité de sociologie, t.I., 4a ed., París, PUF, 1962, cap.III, págs.173 y sigs.; GURVITCH, G.: Elementos de sociología jurídica, cit., cap. III.

119Véase GURVITCH, G.: Elementos de sociología jurídica, cit., cap.III, Segunda Sección. 
En el análisis de la estratificación social120 adquiere un lugar significativo la configuración de las "clases sociales" dentro de la fenomenología de los grupos particulares. Gurvitch destaca seis rasgos característicos de las clases: su radical incompatibilidad, su carácter normalmente refractario a la penetración por la sociedad global, su tendencia hacia una intensa estructuración y, finalmente, su carácter de agrupamientos de hecho y a distancia. Así, las define como "grupos particulares de hecho y a distancia caracterizados por su suprafuncionalidad, su tendencia hacia una extremada estructuración, su resistencia a la penetración por la sociedad global y su incompatibilidad radical con las otras clases"121.

En ese entramado social Gurvitch hace referencia a las "sociedades globales"122, que para él son los fenómenos sociales totales al mismo tiempo los más amplios y los más impositivos, los más ricos en contenido y de ascendencia en una realidad social determinada. Ostentan una soberanía social respecto a todos los conjuntos, sectores, colectividades, elementos componentes que lo integran, y una soberanía jurídica que delimita la competencia de todos los grupos (comprendiendo también al Estado, cuya soberanía política no ha cesado jamás de ser relativa y subordinada, desafiando todas las apariencias contrarias); pueden afirmar una soberanía económica, aunque no es siempre el caso. Toda sociedad global está siempre estructurada (y no solamente estructurable), y en su estructura entran organizaciones. Desde el punto de vista morfológico, las sociedades globales son, la mayor parte, de muy vasta envergadura (sociedades feudales, sociedad del capitalismo organizado, sociedad fascista, sociedades de tipo colectivista...). Por lo demás, toda sociedad global participa de una civilización y contribuye de algún modo a crearla123.

Gurvitch establece una correlación entre la presencia de múltiples grupos sociales y la emanación de un Derecho social autonómo extraestatal que expresa formalmente su poder normativo. En su esquema de pensamiento subyace la idea de que cada grupo social activo constituye un centro creador de su propio Derecho social autónomo (las comunidades económicas nacionales e internacionales, las empresas, los sindicatos, las iglesias, etcétera) y que en el sistema jurídico pluralista de la sociedad global coexisten distintos

120Puede consultarse GIDDENS, A.: La estructura de clases en las sociedades avanzadas, Madrid, Alianza, 1993; WRIGHT, E.O.: Clases, Madrid, Siglo XXI, 1994; CROMPTON, R.: Clases y estratificación, Madrid, Tecnos, 1994; REISSMAN, L.: "Estratificación social", en SMELSER, N.J.: Sociología, Madrid, Euramerica, 1974, págs. 269 y sigs.

121 Véase GURVITCH, G.: Teoría de las clases sociales, Madrid, Edicusa, 1971, Tercera parte ("Exposición sistemática"), págs.205 y sigs., sobre los caracteres cardinales de las clases sociales, en particular pág.206. Donde, por lo demás, muestra una especial preocupación por evitar la sustitución de la categoría de la estratificación social por la de las clases sociales. Gurvitch proporciona una definición más exhaustiva de las clases sociales: "Las clases sociales son grupos particulares de muy vasta envergadura que representan macrocosmos de grupos subalternos, macrocosmos cuya unidad se basa en su suprafuncionalidad, su resistencia a la penetración por la sociedad global, su radical incompatibilidad entre sí, su estructuración creciente que implica una conciencia colectiva predominante y otras culturas específicas; estos grupos sólo aparecen en las sociedades globales industrializadas cuyos modelos técnicos y cuyas funciones económicas están particularmente acentuadas y tienen, además, los siguientes rasgos: son grupos de hecho, abiertos, a distancia, de división permanente, inorganizados, que sólo poseen la coacción condicional" (Ibid.,pág.234).

122Véase GURVITCH, G.: "Les sociétés globales", en Traité de sociologie, t.I., 4a ed., París, PUF, 1962, págs. 216 y sigs.

123Cfr.GURVITCH, G.: La Vocation actuelle de la sociologie, vol.I, cit., págs. 447 a 448. 
ordenamientos jurídicos particulares124. Existe, pues, una coexistencia plural de derechos sociales autónomos. Dentro de su concepción pluralista -que no puede eludir cierto organicismo institucionalista125-, las unidades sociales o comunidades sociales se presentan encadenadas entre sí, con multitud de eslabones. Así, si todo grupo particular tiende a tener su propio Derecho social autónomo, sin embargo se halla también integrado en grupos más amplios que reflejan la presencia de un interés común general frente a los intereses particularistas en juego correspondientes a cada grupo aisladamente considerado. De tal modo que, en última instancia, se hace primar en caso de conflicto insalvable el interés general sobre los intereses parciales correspondientes a cada uno de los derechos sociales particularistas. Gurvitch establece, pues, una jerarquía126 entre el derecho social común de la sociedad global (nacional o internacional) y los derechos sociales particulares (correspondientes a las colectividades o grupos particulares presentes en aquélla). Gurvitch asume un paradigma sociológico integrado, y en este sentido Gurvitch trabaja desde la convicción de que el mundo puede estudiarse en términos de niveles "horizontales" o micromacro. Pero para crear los principales niveles de análisis social, Gurvitch cruza sus

124Véase L'Expérience Juridique et la Philosophie Pluraliste du Droit, París, Pedone, 1935, págs.146-147.

125No se olvide la influencia que sobre él ejerció el pensamiento de autores institucionalistas como Duguit y Hauriou. Véase GURVITCH, G.: L'Idée du Droit Social. Notion et Système du Droit Social, París, Sirey, 1932 (reimpresión alemana de la edición de París de 1932, Scientia Verlag Aalen-1972), passim. Véase del propio GURVITCH, G.: Elementos de sociología jurídica, cit., págs. 109 y sigs. Gurvitch había encuadrado a Duguit dentro de la que denominó "Escuela de derecho social". Esa influencia también es perceptible en otros socialistas democráticos como LASKI, H.J.: "La conception de 1' État de Léon Duguit", en Archives de philosophie du droit et de sociologie jurídique, núm. 1-2 (1932). Al respecto, consúltese MONEREO PÉREZ, J.L.: La democracia en crisis: Harold J. Laski, Barcelona, Ediciones de Intervención Cultural/El Viejo Topo, 2004, págs. 7 y sigs., y 37 y sigs. Del mismo GURVITCH, G.: La idea del Derecho Social. Noción y Sistema de Derecho Social. Historia doctrinal desde el siglo XVII hasta el fin del siglo XIX, traducción, edición y estudio preliminar, "La idea del 'Derecho Social' en la teoría general de los derechos: El pensamiento de Gurvitch" (pp. VII-LV), a cargo de J.L. Monereo Pérez, y A. Márquez Prieto, Granada, Ed. Comares (Col. Crítica del Derecho), 2005, págs. 657 y sigs. ("La idea del derecho social y el objetivismo sensualista de L. Duguit").

126GURVITCH, G.: L'Idée du Droit Social, cit., pás. 47 y sigs.; GURVITCH, G.: L'Expérience Juridique et la Philosophie Pluraliste du Droit, París, Pedone, 1935, pág.147. La connotación organicista es manifiesta cuando afirma que todos los derechos sociales particularistas deben subordinarse al derecho social común de la economía nacional (L'Idée du Droit Social, cit., pág.51). En general, Gurvitch contempla la vida social como presidida por un conflicto permanente de contrarios intereses que se hallan en equilibrio móvil y cambiante en el marco de la realidad social. Véase GURVITCH, G.: "Les syndicats e l'intérêt general", en L' homme réel, núm. 1 (1933), págs. 13 a 19. Es significativa la "Presentación" del socialista liberal C. Rosselli, a la traducción italiana, I sindicati e l' interesse generale, en Quaderno, núm. 10 de Giustizia e Libertà, Febrero 1934, págs. 29 a 36, verificando allí confluencias de pensamiento jurídico-crítico. Puede consultarse la obra iussocialista de ROSELLI, C.: Socialismo liberale (1930), Torino, Einaudi, 1979. Para la interrelación histórica existente entre las tendencias del socialismo jurídico y las elaboraciones del Derecho Social, véase ampliamente MONEREO PÉREZ, J.L.: Fundamentos doctrinales del Derecho Social en España, Madrid, Ed. Trotta, 1999; MONEREO PÉREZ, J.L.: Reformismo social y socialismo jurídico: Antón Menger y el socialismo jurídico en España, estudio preliminar a MENGER, A.: El Derecho Civil y los Pobres, trad. Adolfo Posada, revisión, edición crítica y estudio preliminar, a cargo de J.L. Monereo Pérez, Granada, Ed. Comares (Col. Crítica del Derecho), 1998, págs.7-114; MONEREO PÉREZ, J.L.: Pluralismo jurídico y Derecho social: La sociología del Derecho de Gurvitch, Estudio Preliminar a la obra de GURVITCH, G.: Elementos de sociología jurídica, edición de J.L. Monereo Pérez, Granada, Editorial Comares (Col. Crítica del Derecho), 2001, págs. XIII-CXLVI. 
dimensiones horizontales y verticales y obtiene así un cuantioso número de niveles de análisis social que permite desvelar los entresijos de las sociedades complejas127.

Sin embargo, Gurvitch mantiene una concepción dialéctica y pluralista de la misma noción de interés común o general, ya que dentro de su posición antiestatalista considera que el Estado, y, en general, los poderes públicos, no son los intérpretes exclusivos de dicho interés común, ni tampoco ostentan el monopolio para representar e institucionalizar su protección y defensa. En efecto, en opinión de Gurvitch, el interés general no es uniforme, presenta en sí una estructura proteiforme, de manera que, en la experiencia jurídica se constataría la existencia de una multiplicidad de órdenes de Derecho social común, con la particularidad de que cada uno de ellos constituye una representación de las varias dimensiones o aspectos del interés general o común128. Todo ello representa la complejidad de la realidad social de las sociedades contemporáneas. La concepción del interés general o interés común es en sí misma pluralista, ya que concibe a éste como un equilibrio de intereses contrapuestos, toda vez que la oposición de intereses es connatural a todo sistema social, teniendo en cuenta que existen diversos aspectos del interés común (interés común político, económico, religioso, etcétera)129. Es así que el sistema jurídico pluralista comprende una diversidad de órdenes de derecho social común, que expresan contradictoriamente la mutiplicidad de aspectos del interés general.

La sociedad democrática debería aspirar, según Gurvitch, a construir un derecho social común representativo de la organización global de la economía nacional, que partiría del reconocimiento de una representación paritaria de las asociaciones profesionales y de consumidores. Este procedimiento de interpretación dialéctica del interés común podría conducir a la regulación democrática de la vida económica. Gurvitch, siempre antiestatalista (como aspecto subyacente a su pensamiento), realza que esta forma de articulación paritaria entre los intereses organizados sería independiente del Estado. Es aquí donde Gurvitch expresa su modelo de democracia económica e industrial130, donde concibe un sistema autogestionario, respetuoso de la autonomía de los grupos sociales particulares. En el campo de la económica nacional propone la fórmula de los Consejos Nacionales Económicos, mientras que en el ámbito de las empresas singulares, cree necesaria una transformación de la estructuras de la propiedad, favoreciendo la instauración de un sistema de propiedad socialista o colectivista, a través de mecanismos de socialistación no estatalista ("propiedad federalista"131, perteneciente al grupo y a los individuos que lo integran). Su propuesta es que la empresa constituya una "asociación de colaboración" en el cuadro de una

127 Autores como George Ritzer reconocen la influencia en su propio modo de pensar del paradigima integrado trazado por Georges Gurvitch y también Edel y Bosserman. Cfr. RITZER, G.: Teoría sociológica moderna, trad. M. T. Casado Rodríguez, revisión de M. Requesa, Madrid, Ed. McGraw-Hill/Interamericana de España, 2002, pág. 447-448.

128En este sentido GURVITCH, G.: L'Idée du Droit Social, cit., págs. 39 y sigs.

129Véase GURVITCH, G.: L'Idée du Droit Social, cit., págs. 41-42; GURVITCH, G.: L'Expérience Juridique et la Philosophie Pluraliste du Droit, París, Pedone, 1935, pág.148.

130Véase infra, apdo. IV.

131Nótese la influencia aquí del pensamiento de Proudhon. Cfr. GURVITCH, G.: Proudhon. Su vida, su obra, su filosofía, trad. J.Marfá, Madrid, Eds. Guadarrama, 1974. 
colectivización del sistema económico. Dicha empresa estaría regulada por su propio derecho social, por contraposición a la actual estructura de dominación ("asociación de dominación") de la empresa capitalista132.

En esta línea de pensamiento, se puede decir que para nuestro autor la alienación del trabajador en la empresa es superable mediante la potenciación de fórmulas de "democracia industrial", especialmente a través de su grado más elevado, la "autogestión obrera". Por eso, distinguirá entre las estructuras representativas de simples "consejos de control" de la fórmula más incisiva de los "consejos de gestión", "llamados -precisamente- a dirigir la marcha general de las empresas y de las industrias desde el punto de vista económico y técnico". Para que el control de los trabajadores funcione efectivamente, es necesario que los trabajadores tengan el derecho de participar en la gestión misma de las empresas y de las industrias. Esto no es posible sin instituir "consejos de gestión obligatorios"133.

Con todo, en el pensamiento de Gurvitch, el sistema jurídico pluralista es un todo de conformación heterogénea, en cuyo interior el ordenamiento estatal refleja la representación del interés común en su dimensión política (derecho de la comunidad política), de tal manera que los otros aspectos del interés común o general (religioso, económico, etcétera) vienen a ser representados a través de comunidades sociales particulares y su derecho social autónomo (empresas, cooperativas sindicatos, asociaciones de consumidores, etcétera).

El Derecho de esas comunidades particulares y del Estado queda en situación de subordinación respecto al Derecho de la comunidad internacional134. Gurvitch acepta el pluralismo jurídico con todas sus consecuencias legítimas, pero entiende que el pluralismo jurídico en las sociedades democráticas debe tener un mínimo referente jurídico común a todas las culturas jurídicas representado por las Declaraciones universales de los derechos humanos en todas sus dimensiones (civiles, políticos, económicos, sociales y culturales). De este modo su visión pluralista, que parte de la múltiplicidad de células sociales creadoras de Derecho, es inequívocamente universalista, como lo es significativamente también su concepción de los derechos sociales fundamentales135.

\section{El modelo de pluralismo jurídico democrático de Gurvitch y su confrontación con otros paradigmas pluralistas}

\subsection{Pluralismo social "versus" pluralismo jurídico}

Para Gurvitch el ámbito de lo jurídico no se limita al Derecho del Estado, al Derecho emanado de los poderes públicos. Existen otras formas de creación del Derecho: el Derecho

132Véase GURVITCH, G.: Le Temps présent et l'idée du Droit Social, París, ed.J.Vrin, 1932, Sección I, págs. 13 y sigs., y 84 y sigs.

133GURVITCH, G.: La Déclaration des Droits Sociaux, New York, Editions de la Maison Française, 1944 (ed., francesa, París, Librairie Philophique J.Vrin, 1946), pág.133.

134GURVITCH, G.: L'Idée du Droit Social. Notion et Système du Droit Social, París, Sirey, 1932, págs.37 y sigs.; GURVITCH, G.: Le Temps présent et l'idée du Droit Social, París, ed.J.Vrin, 1932,págs.136 y sigs.

135GURVITCH, G.: La Déclaration des Droits Sociaux, New York, Editions de la Maison Française, 1944 (ed., francesa, París, Librairie Philophique J.Vrin, 1946), passim. 
emanado directamente de la sociedad y de los grupos sociales, el cual puede tener también la condición y el tratamiento técnico de Derecho positivo. En tal sentido el desarrollo del capitalismo organizado -sociedades por acciones, carteles y trusts-, del sindicalismo profesional, de las convenciones colectivas de trabajo, desagrega al mismo tiempo los principios de la soberanía nacional y de la autonomía de la voluntad y asimismo de la libertad de contratación. Dichas instituciones se expresan mediante un Derecho social organizado que hace concurrencia al marco del Derecho del Estado136. Frente a esta realidad jurídica quedaría desvelada la ficción del Estado contemporáneo como detentador de una soberanía absoluta, que supondría el reconocimiento de un poder superior sobre cualquier otro poder social "neutralizado" y la reducción de todo Derecho al Derecho del Estado en coherencia con el monopolio de la producción jurídica por él detentada e impuesta. De ahí la sustancial identificación entre Derecho y Estado nación137. Todas las teorías del pluralismo jurídico y político, incluida evidentemente la mantenida por el propio Gurvitch, se sitúan en contraposición a esa visión monolítica del poder jurídico y político detentado por el Estado y defienden la existencia de otros ordenamientos jurídicos fuera del Estado productores de reglas jurídicas. El Derecho estatal (ordenamiento jurídico de la sociedad política organizada) es uno más (aunque en posición de supremacía por él impuesta) de los ordenamientos jurídicos que coexisten y se yuxtaponen en un determinado espacio geopolítico, autolimitándose entre sí.

La existencia de ese Derecho extraestatal surgido de la sociedad y de los grupos particulares que se mueven en su interior, que coexiste con el Derecho emanado de los poderes públicos, permite afirmar en Gurvitch el pluralismo jurídico y social y, con ello, en coherencia lógica, la existencia misma de una pluralidad de fuentes de producción jurídica. Gurvitch podrá decir con Lévy-Bruhl que el derecho es el conjunto de reglas obligatorias que determinan las relaciones sociales impuestas en todo momento por el grupo al que pertenece el individuo, por lo que si éste forma parte de varios grupos se encontrará sometido a distintos ordenamientos jurídicos138. Frente al monismo jurídico, que considera que el Derecho es obra exclusiva de un grupo político ("sociedad global")139, el pluralismo jurídico se basa en la experiencia histórica y en la realidad social del presente para poner de manifiesto la existencia, junto al Derecho estatal, de Derechos supra-estatales y de Derechos infra-

136Véase GURVITCH, G.: Elementos de sociología jurídica, cit., Introducción, pág.228.

137El paradigma es el Estado Leviatán de Hobbes. Véase al respecto, BOBBIO, N.: La teoría de las formas de gobierno en la historia del pensamiento político, México, FCE, 1992, págs.95 y sigs., y ampliamente su ensayo "La teoría política de Hobbes", en Thomas Hobbes, Barcelona, Plaza \& Janés Editores, 1991, págs.48 a 108 , y sigs.

138La concepción pluralista de Gurvitch se aproximaría a la la noción de "polisistemia simultánea" de André-Jean Arnaud, que se caracteriza por la presencia de varios sistemas jurídicos "vividos" o "concebidos" en un mismo tiempo y un mismo espacio. Cfr. ARNAUD, A.J.: Critique de la raison juridique. 1. Oú va la sociologie du droit, París, L.G.L.J., 1981, págs.23 a 26. En el mismo sentido ARNAUD, A.J.y FARIÑAS DULCE, M.J.: Sistemas jurídicos: elementos para un análisis sociológico, Madrid, BOE, 1996, págs. 281 y sigs., con interesantes reflexiones sobre el pluralismo jurídico contemporáneo. Para estos autores la plisistemia simultánea "consiste en la existencia, en su mismo tiempo y lugar, y con respecto a las mismas personas, de sistemas jurídicos divergentes" (Ibid., pág.282).

139La posición contemporánea más decidida en este sentido es la del positivismo de Kelsen. Véase KELSEN, H.: Teoría pura del Derecho (1960), $7^{\text {a }}$ ed., México, Ed.Porrúa, 1993, passim. 
estatales140. En este sentido Gurvitch, desde un pluralismo jurídico esencialmente antiestatalista, rehusa identificar el Derecho y el Estado como se hace desde las concepciones monistas y unilaterales del fenómeno jurídico.

Esa concepción pluralista del Derecho se aparta del monismo jurídico que afirma la unidad existente entre el espacio jurídico y el espacio territorial, ya que, como ha demostrado la experiencia jurídica, en un mismo territorio (nacional o supranacional) puede producirse una coexistencia entre diversos sistemas jurídicos, porque diferentes órdenes o espacios jurídicos pueden superponerse en una mismo lugar, lo cual determina la existencia de un ámbito espacial compartido por varios órdenes jurídicos. De esta manera, propone un pluralismo en sentido "fuerte", el cual supone la superposición simultánea de varios sistemas jurídicos141. Ni siquiera puede afirmarse que un sistema jurídico siempre acote su eficacia dentro de un territorio estrictamente delimitado (es el caso del Derecho canónico o del Derecho autónomo de los grupos económicos transnacionales; típicos órdenes jurídicos de base no territorial). El pluralismo jurídico ha supuesto una ampliación del horizonte de la experiencia jurídica dentro y fuera del Estado nacional, el cual no puede pretender ya monopolizar la producción jurídica ni si quiera en su propio espacio territorial de supremacía. En efecto, la sociedad contemporánea es una sociedad pluralista integrada por distintos sistemas u órdenes jurídicos autónomos, o relativamente autónomos, donde las organizaciones y grupos sociales vertebran la sociedad civil y mediatizan la relación de los individuos con el sistema político institucional142.

El fundamento científico de este pluralismo jurídico y social viene constituido por la presencia en el entramado social de los que denomina "hechos normativos" capaces de crear Derecho objetivo. En efecto, en el sistema de Gurvitch, los "hechos normativos" constituyen fuentes de validez jurídica, es decir, de positividad de todo Derecho. Para él, las colectividades sociales, los grupos sociales, dan origen a hechos ostentan naturaleza normativa143. Así el orden jurídico de la sociedad no se limita al orden jurídico del Estado. Según él cada sociedad está integrada de una multiplicidad de agrupaciones particulares y cada grupo particular (cada unidad colectiva real) se compone de una multiplicidad de formas de sociabilidad. A estas agrupaciones corresponde un tipo específico de Derecho (Derecho sindical, Derecho del Estado, Derecho cooperativo, derecho canónico, etcétera). En el marco del Derecho que corresponde a los diversos tipos de agrupaciones y en los tipos de la sociedad global (Derecho feudal, Derecho burgués, Derecho europeo, Derecho oriental, Derecho arcaico o Derecho civilizado) se combina siempre una multiplicidad de

140Véase también LÉVY-BRUHL, H.: Sociologia do direito (1961), Sao Paulo, Livraria Martins Fontes Editora Ltda, $2^{\circ}$ ed., 1997.

141Santi Romano había admitido la existencia de una pluralidad de ordenamientos jurídicos que viven junto al ordenamiento del Estado y se interrelacionan de modos diferentes. Cfr. ROMANO, S.: El ordenamiento jurídico, Est.Preliminar de S.Martín-Retortillo, Madrid, Instituto de Estudios Políticos, 1963, Parte II ("La pluralidad de los ordenamientos jurídicos y sus relaciones").

142Para la verificación de los órdenes jurídicos particulares residenciado en el ámbito de la autonomía privada ("derecho de los particulares"), puede consultarse la todavía sugestiva obra de CESARINI SFORZA, W.: El Derecho de los particulares, trad. de José Calvo González, Madrid, Civitas, 1986, 2ª edición en 2016.

143En este sentido GURVITCH, G.: Sociología del Derecho, Argentina, Ed.Rosario, 1945, pág.67. 
especies de Derecho ligadas a la pluralidad de las formas de sociabilidad. Esto produce una trama de tensiones perpetuas y conflictos que animan la vida efectiva de todo Derecho y se desconocerían las profundidades del inextricable pluralismo que la penetra y que es en sí mismo un factor de transformaciones permanentes de la realidad jurídica, de su dinamismo interno. De esta manera no se puede hablar de una dirección unilinial en el desarrollo de las instituciones jurídicas144. Cada grupo social particular, y su combinación con otros, representa un foco especial de generación autónoma de un orden de Derecho, con independencia de sus relaciones con el poder público, sin que para Gurvitch el principio de soberanía produzca ninguna jerarquía preestablecida de los grupos y de los cuadros correspondientes de Derecho; deja, por el contrario, la puerta abierta a los cambios y a las variaciones perpetuas en este dominio145.

Existe un Derecho social de carácter extraestatal, como hecho jurídico. Esos hechos normativos pueden generarse espontáneamente o de modo institucionalizado (formalizado y organizado). Es así, que el Estado es para Gurvitch una de las formaciones sociales específicas que presenta la cualidad de crear Derecho objetivo; aunque en la sociedad moderna, organizada en Estado de pluralidad de clases146, éste pretende el monopolio de la producción del Derecho147, llevando a cabo un proceso de máxima racionalización y juridificación del mundo de la vida148. Los "hechos normativos" se afirman como fundamento de la fuerza obligagoria y de la eficiencia de la regla jurídica, por lo que en ellos converge toda la complejidad del fenómeno del Derecho, comenzado por el mismo problema de las fuentes del Derecho positivo (problema que ocupa un lugar central en la ciencia del Derecho), ya que los "hechos normativos" son las "fuentes primarias" diferenciables de las fuentes secundarias o formales, las cuales remiten a los procedimientos técnicos para constatarlos formalmente149. De este modo se superaría el "fechismo de la

144Véase GURVITCH, G.: Elementos de sociología jurídica, cit., Introducción, pág.26.

145Véase GURVITCH, G.: Elementos de sociología jurídica, cit., Introducción, pág.195. Por el contrario, para Santi Romano, el Estado constituye un principio de orden superior que unifica y armoniza a los grupos sociales menores. Cfr. ROMANO, S.: El ordenamiento jurídico, Madrid, IEP, 1963. De ahí que Bobbio indique que Santi Romano es ideológicamente un monista. Cfr.BOBBIO, N.: "Teoría e ideología en la doctrina de Santi Romano", en BOBBIO,N.: Contribución a la teoría del Derecho, trad. y estudio preliminar, por A. Ruiz Miguel, Valencia, Fernando Torres Editor, 1980, págs. 155 y sigs.; igualmente, COSTA,P.: Lo Stato immaginario, Milano, Giuffrè, 1986. Sobre la crítica de Gurvitch al principio de soberanía, véase TANZI, A.: Georges Gurvitch. Il progetto della libertà, Pisa, Pacini, 1980, págs. 45 y sigs.

146Véase GIANNINI, M.S.: El poder público, Madrid, Civitas, 1991.

147Ese proceso de racionalización se ha mostrado históricamente constante, "comprimiendo" al máximo las formas de la vida humana. Es clásica la reflexión, al respecto, de Max Weber. Cfr.WEBER, M.: Economía y Sociedad, México, FCE, 1983. Al respecto, ampliamente, MONEREO PÉREZ, J.L.: Modernidad y capitalismo. Max Weber y los dilemas de la Teoría Política y Jurídica, Barcelona, Ediciones de Intervención Cultural/El Viejo Topo, 2013, espec., Capítulo I ("La teoría de la racionalidad en Max Weber. Concepción general de la sociología del Derecho en Max Weber") y Capítul II ("La racionalidad del Derecho, de la Economia y del Poder en la sociedad moderna"), págs. 15 y sigs., y 169 y sigs., respectivamente.

148Véase HABERMAS, J.: Teoría de la acción comunicativa, 2 vols., Madrid, Taurus, 1987; Id.: Facticidad y validez, Madrid, Trotta, 1998.

149Su concepción se expone en GURVITCH, G.: L'Idée du Droit Social, cit., págs.132 y sigs. Una ley, un estatuto, una convención, la costumbre en sí misma no producen la positividad en Derecho más que en la medida en que ellos se presentan como expresiones o, más exactamente, como constataciones de "hechos normativos" preexistentes. Toda su autoridad no refleja más que la autoridad de los "hechos normativos" que, son realidades 
ley" en el sentido formulado por François Gény150. Estos "hechos normativos" encuentran su justificación jurídica en el hecho mismo de su existencia, pero este hecho presenta en si mismo un valor jurídico positivo y sirve a la realización de la Justicia. El hallazgo y el estudio científico de tales "hechos normativos" exige de un método de comprensión propio y específico que él llama "ideal-realismo" jurídico (bajo la influencia de Fichte), como concepción superadora de la oposición entre el "sociologismo" y el "normativismo"151.

\subsection{El sistema pluralista del Derecho en Gurvitch}

\section{A) Fundamentación}

Las bases del pensamiento pluralista de Gurvitch son extraordinariamente variadas e interdisciplinares. Comprenden desde la filosofía hasta la sociología, pasando por la teoría jurídica. En esta pespectiva, es de destacar su proclividad hacia las doctrinas del pluralismo social y jurídico, especialmente las doctrinas institucionalistas 152 y el pluralismo de Proudhon; doctrinas, todas ellas, notoriamente opuestas a las concepciones estatalistas del Derecho y abiertas al entendimiento de la realidad social como una totalidad multidimensional 153 .

En realidad, en el pensamiento de Gurvitch el pluralismo adquiere una dimensión totalizadora. Se trata de una teoría que trata de explicar la sociedad en su conjunto, y de una ideología que pretende resolver el problema de la centralización del poder, sobre todo respecto del poder detentado por el Estado. Por ello propone una concepción pluralista de la sociedad, un modelo de sociedad integrada por una multiplicidad de grupos y centros de poder, en posición dialéctica de conflicto y colaboración, siendo el Estado el centro de poder predominante (pero no el único), el cual pretende ejercer una función de hegemonía sobre los demás centros de poder promoviendo su integración. Para la teoría democrática de Gurvitch, la pluralidad de asociaciones y organizaciones contribuyen a la extensión de la participación de los individuos (que no están aislados en la sociedad civil154) en el sistema político. En el sistema pluralista no existe una fuente de autoridad única, sino una multiplicidad de poderes decisorios. Contribuye a desarrollar el principio democrático no

creadoras de su propio ser para engendrar Derecho, incardinando valores jurídicos positivos y garantizando por su existencia misma "la eficiencia de las reglas de derecho" (Ibid.,pág.134).

150Véase GURVITCH, G.: L'Idée du Droit Social, cit., pág.134.

151Véase, detenidamente, GURVITCH, G.: L'Idée du Droit Social, cit., págs.113 y sigs. En realidad, la teoría de los "hechos normativos" en tanto que "fuentes primarias" de la positividad del Derecho -punto donde se unifican la autoridad y la eficiencia- desposeen a las "fuentes secundarias" o "formales" de su excesivo prestigio, y rebasan su papel en la vida del Derecho positivo (Ibid.,pág.134).

152La influencia de las teorías institucionalistas en el pensamiento de Gurvitch es manifiesta, y en gran medida constitutiva de su propia concepción pluralista. Véase GURVITCH, G.: L'Idée du Droit Social, cit., Quinta Parte, cap.III (La idea del derecho social y el objetivismo metafísico de Maurice Hauriou), págs.647 a 710. Puede consultarse HAURIOU, M.: La teoría de la institución y de la fundación, Buenos Aires, AbeledoPerrot, 1968. HAURIOU, M.: Principios de Derecho Público y Constitucional, traducción, estudio preliminar, notas y adiciones Carlos Ruíz del Castillo; Edición al cuidado de J.L.Monereo Pérez, Granada, Ed. Comares (Col. Crítica del Derecho), 2003.

153Sobre estas influencias, véase BALANDIER, G.: Gurvitch, París, P.U.F., 1972, pág.16.

154De ahí su radical oposición a toda forma de individualismo social, político o jurídico. 
sólo desde arriba sino fundamentalmente desde abajo. No obstante a la teoría e ideología pluralista de Gurvitch no es fácil oponerle las frecuentes críticas a las teorías pluralistas en el sentido de la ingenuidad de pensar que en la sociedad actual existe un pluralismo que ha distribuido el poder entre los individuos y los grupos de pertenencia cuando la realidad empírica pone de manifiesto el reforzamiento de las élites en el poder155, por un lado, y por otro, la crítica que ha podido formularse porque en la sociedad capitalista actual el "hombre unidimensional" penetra en todos los ámbitos de la vida social156. No es fácil, en efecto, proyectar estas críticas al pensamiento pluralista de Gurvitch, ya que éste situaba su pluralismo jurídico como una realidad emergente que para su culminación como verdadera sociedad pluralista exigía un cambio estructural en el modelo de sociedad. No se olvide la adscripción de Georges Gurvitch al pluralismo socialista y la búsqueda de una sociedad integradora de la diversidad existente: su apuesta no por el particularismo sino por la unidad en la pluralidad donde se desenvuelve la personalidad humana.

Gurvitch construye un tipo original del más variado pluralismo socialista, que parte del rechazo del individualismo y verifica la realidad del "hombre asociado" frente a la concepción del "hombre aislado". Se inspiró en el pensamiento de Proudhon para elaborar su teoría del pluralismo jurídico y social. Con él afirmará la existencia de un "derecho social" nacido de la misma sociedad articulada a traves de agrupaciones sociales, el cual se contrapone al "derecho estatal". Esa concepción del derecho social se basa en una teoría de los derechos sociales del hombre157, de manera que se contemple al hombre situado en la estructura social, y por ello atendiendo a la multiplicidad de posiciones jurídicas y sociales que ostenta en la sociedad (productor, consumidor...). Sus vínculos son mayores con el pluralismo cristiano (sobre todo de Emmanuel Mounier, que se inspira en el propio Gurvitch, pero acentuando más la idea personalista y comunitaria) que en el pluralismo "guildistasocialista" definido por G.D.H. Cole y S.G. Hobson, que parte de una plena disociación de la política y la economía cuya organización es atribuida a las distintas organizaciones de intereses, aunque tenga puntos de coincidencia como la afirmación de una multiplicidad de centros de poder, la oposición al individualismo y la pretensión de instaurar formas incisivas de democracia económica e industrial158.

\section{B) Rechazo de la reducción del Derecho al "Derecho estatal"}

La defensa del pluralismo jurídico determina que Gurvitch se muestre contrario a las concepciones estatalistas del Derecho. Rechaza la reducción del Derecho al "Derecho estatal". Y no sólo criticará a las concepciones racionalistas decimonónicas, sino también a las doctrinas contemporáneas del positivismo jurídico (señaladamente Kelsen) y del racionalismo sociológico de Weber, al cual reprocha el haber aceptado las categorías

155Véase WRIGHT MILLS, C.: La élite del poder, México, F.C.E., 1956.

156Véase la crítica de MARCUSE, H.: El hombre unidimensional, Barcelona, Seix Barral, 1964).

157Véase GURVITCH, G.: La Déclaration des Droits Sociaux, New York, Editions de la Maison Française, 1944 (ed. francesa, París, Librairie Philophique J.Vrin, 1946).

158Sobre el "guildismo-socialista", véase la propia exposición de G.D.H. COLE en su historia del pensamiento socialista. Cfr. COLE, G.D.H.: Historia del pensamiento socialista, vol.III, México, FCE, 1974. 
aportadas por la dogmática jurídica "en el vacío y privadas de cualquier vínculo con la realidad viva del Derecho del que no son más que los símbolos más o menos rígidos"159. Afirma con rotundidad que existen distintos centros de poder jurídico, el poder público y los grupos sociales.

La hipótesis del pluralismo jurídico supone la existencia de varios espacios jurídicos que se superponen y coexisten en un mismo lugar en una permanente tensión dialéctica, de tal manera que el espacio jurídico está constituido por una red de relaciones de Derecho160. Para nuestro autor la sociedad global tiene una composición multívoca, existiendo entre ésta y los individuos, grupos particulares. La sociología jurídica se interroga sobre si un grupo particular, que forma un espacio social, forma igualmente un espacio jurídico, o si esto último constituye una prerrogativa reservada a la sociedad global. Normalmente, los juristas dogmáticos (formalistas) hacen coincidir el espacio jurídico con la sociedad global y, en términos modernos, con el Estado. Por ello rechazan que pueda existir generación espontánea de derecho en los grupos particulares. A la inversa, los sociólogos del Derecho se inclinan comúnmente a admitir que los grupos particulares tienen en sí mismos un poder de creación jurídica. Es así que de un modo general segmentan y diversifican el espacio jurídico. No es otro el sentido que se debe atribuir a la conocida hipótesis del pluralismo jurídico161.

En este sentido, como realzara Henri Lévy-Bruhl162, respecto a qué grupos pueden imponer a sus miembros normas de Derecho existen dos escuelas, que pueden ser calificadas como monistas o pluralistas. En la primera se sitúan aquellos juristas que acreditan que un único tipo de grupo social, o grupo político -actualmente se habla de la denominación genérica de sociedad global-, está habilitado para crear normas de Derecho. El otro, profesa, por el contrario, que existen otros agrupamientos sociales que pueden instituir verdaderas normas jurídicas. Para estos últimos, existen Derechos que no emanan de la competencia de los órganos de la sociedad global. Hay Derechos supranacionales y Derechos infranacionales o infraestatales. Por otra parte, la posición y la relación de los ordenamientos particulares es entre sí contradictoria. Existen tensiones y conflictos inevitables en el seno de un mismo sistema jurídico general163.

159GURVITCH, G.: Sociología del Derecho, Argentina, Ed.Rosario, 1945.

160La superposición de diversos ordenamientos opera respecto de un mismo territorio y, en su caso, respecto de una misma población. Dichos ordenamientos jurídicos pueden ser, en todo o en parte, mutuamente incompatibles. En este sentido FERRARI, V.: Acción jurídica y sistema normativo. Introducción a la Sociología del Derecho, Madrid, Ed. Dykinson, 2000, pág.253.

161Cfr.LÉVY-BRUHT, H.: Sociologie du droit, cit., pág.25. El texto citado es de CARBONNIER, J.: Sociología jurídica, trad. L.Diez-Picazo, Madrid, Tecnos, 1977, pág.118. Sobre las distintas concepciones monistas y pluralistas del Derecho, desde los orígenes históricos, véase el importante trabajo de ROSS, A.: Teoría de las fuentes del derecho. Una investigación a la teoría del derecho positivo sobre la base de investigaciones histórico-dogmáticas, Madrid, Centro de Estudios Políticos y Constitucionales-CEPC, 2000.

162LÉVY-BRUHL, H.: Sociologia do direito (1961), Sao Paulo, Livraria Martins Fontes Editora Ltda, $2^{\circ}$ ed., 1997, págs.24 y sigs.

163Véase, al respecto, LÉVY-BRUHL, H.: "Tensions et conflits au sein d'un même système juridique", en Cahiers internationaux de sociologie, vol.XXX, 1961, págs.35 y sigs. 
De este modo para Gurvitch, y en general, los teóricos del pluralismo en sentido estricto, el Estado no detenta un monopolio en la creación de Derecho, existen otros poderes autónomos de creación normativa de carácter extraestatal y de naturaleza privada. Esto determina que el Derecho, el fenómeno jurídico, es en sí múltiple y heterogéneo, porque dentro de un mismo sistema social pueden coexistir sistemas jurídicos diferentes. Más allá del dato científico social de la constatación en los hechos que pondrían de manifiesto ese pluralismo, las orientaciones o corrientes de pensamiento pluralistas tienen una dimensión de política del Derecho, ya que suponen una crítica al dogma del monopolio y de la soberanía del poder estatal respecto a la creación del Derecho, y postulan, a la par, una mayor autonomía de los poderes jurídicos y, consiguientemente, del sistema de fuentes de producción jurídica. En el caso de Gurvitch, su defensa del pluralismo jurídico entroncaba con sus convicciones filosófico-jurídicas inclinadas hacia el socialismo autogestionario, donde latía una multiplicidad de influencias que iban desde el marxismo164 hasta la doctrina anarquista de Proudhon (más influyente en su pensamiento)165 pasando por el movimiento del derecho libre (especialmente, Ehrlich del cual recoge su visión de un tipo de derecho social de carácter espontáneo166) y el socialismo jurídico, señaladamente de Emmanuel Lévy167. Entiende Gurvitch que el Derecho en el sentido afirmativo del pluralismo jurídico es un punto de partida indisociable - por necesario- para avanzar en el proceso de democratización

164 Tanto más si se tiene en cuenta la pluralidad intrínseca al desarrollo del marxismo crítico y la orientación hacia un socialismo democrático y pluralista. Véase, en una perspectiva de conjunto, MONEREO PÉREZ, J.L.: La tradición del marxismo crítico, Granada, Ed. Comares (Col. Crítica del Derecho. Sección Derecho Vivo), 2011, espec., págs. 201 y sigs. Por lo demás, en su autobiografía reconoce que se había producido un regreso hacia el pensamiento crítico del marxismo. Cfr. "Mon itinéraire intellectuel ou l' exclu de la horde", en Lettres Nouvelles, núm.6 (1958), págs.65 a 83. Publicado después en L'Homme et la Société, I, 1966; y en la recopilación de DELEDALLE, G.y HUISMAN, D.: Les philosophes français d' aujourd' hui pas eux-mêmes. Autobiografhie de la philosophie française contemporaine, París, C.D.U., 1963, págs. 100 a 116; igualmente recogido en DUVIGNAUD, J.: Georges Gurvitch, París, Éditions Seghers, 1969, págs. 79 a 98.

165 Ya se puso de relieve la preferencia esencial de Gurvitch por la doctrina de dicho autor, véase, significativamente, su monografía GURVITCH, G.: Proudhon. Su vida, su obra, su filosofía, trad. J.Marfá, Madrid, Eds. Guadarrama, 1974.

166Para Gurvitch, el Derecho espontáneo es el Derecho inorganizado, engendrado por los "hechos normativos". Cfr. L'Expérience Juridique et la Philosophie Pluraliste du Droit, París, Pedone, 1935, pág.132. Por su parte Ehrlich reconoce el ámbito jurídico normativo y los "hechos del derecho consuetudinario" ("Tatsachen des Gewohnheitsrechts"); y define el Derecho como "las instituciones y medidas sociales que los círculos relevantes de una determinada sociedad consideran el fundamento del orden estatal, social y económico". Cfr. EHRLICH, E.: I fondamenti della sociologia del diritto, Milano, Giufrè, 1976, passim.

167 MENGER, A.: El Derecho Civil y los Pobres, trad. Adolfo Posada, revisión, edición crítica y estudio preliminar, "Reformismo social y socialismo jurídico: Antón Menger y el socialismo jurídico en España" (pp. 7-114), a cargo de J.L. Monereo Pérez, Granada, Ed. Comares (Col. Crítica del Derecho), 1998; MONEREO PÉREZ, J.L.: Fundamentos del derecho social en España, Madrid, Ed. Trotta, 1999; MONEREO PÉREZ, J.L.: La defensa del Estado Social de Derecho. La teoría política de Hermann Heller, Barcelona, Ediciones de Intervención Cultural/El Viejo Topo, 2009; LASKI, H.J.: A Grammar of Politics (1925), London, Allen and Unwin. Trad.esp., T. González García, La Gramática de la Política. El Estado moderno, revisión técnica, edición crítica y estudio preliminar, "La filosofía política de Harold J. Laski (pp. XV-CXVIII)", a cargo J.L. Monereo Pérez, Granada, Comares (Col. Crítica del Derecho), 2002; MONEREO PÉREZ, J.L.: La democracia en crisis: Harold J.Laski, Barcelona, Ediciones de Intervención Cultural/El Viejo Topo, 2004; MONEREO PÉREZ, J.L.: La crisis de la socialdemocracia europea. Eduard Bernstein y la premisas del socialismo reformista, Barcelona, Ediciones de Intervención Cultural/El Viejo Topo, 2012. 
de una sociedad compleja y fragmentada en la que la igualdad y la justicia social son aspiraciones que guían la acción de los poderes públicos y de las organizaciones colectivas. Tenía la convicción de que el proceso de democratización se debería realizar "desde abajo" -aunque con el impulso desde arriba del Estado- a través de mecanismos de autorganización de los grupos sociales y de formas de democracia social y económica.

Para Gurvitch la cosmovisión reductiva del Derecho que proyectan las concepciones monistas y estatalistas, son un producto ya superado de la ideología jurídica racionalista de la codificación, que afirma el dogma de una unidad desde la salvaguardia de un orden perpertuo168 de la paz burguesa169. Sin embargo, en el mundo contemporáneo se ha puesto de relieve la falacia de una tal pretensión monolítica y estatalista del Derecho, ya que se puede constatar empíricamente la existencia de una multiplicidad de centros generadores de Derecho, dentro (comunidades sociales y económicas particulares) y fuera del Estado (sociedad internacional y sociedad europea)170. Para Gurvitch, el poder jurídico recae en los "hechos normativos", lo que determina que los centros de producción normativa pueden ser institucionales o informales, productores, éstos, de Derecho espontáneo.

El problema práctico que se ha suscitado respecto del pluralismo es si se cumple su hipótesis máxima de partida, cual es la existencia de ordenamientos jurídicos autónomos coexistentes en un mismo espacio social. En este sentido cabe señalar que existen ordenamientos particulares integrados en el ordenamiento jurídico general (con lo cual el pluralismo jurídico existe, pero se hace interno al sistema jurídico global; sin embargo no por ello deja de existir como tal171). Es significativo que las Constituciones sociales contemporáneas suelen reflejar ese pluralismo social y jurídico interno, donde se reconduce a una cierta unidad en la diversidad jurídica el pluralismo por ella misma admitido y, a veces, construido. Sin embargo, junto a ese pluralismo integrado a menudo existen también ordenamientos privados no integrados que surgen espontáneamente al margen de las previsiones constitucionales (y de sus eventuales desarrollos en la legislación estatal). Es lo que, de modo significativo, se ha dado en llamar "hechos normativos disidentes"172.

168Sobre el tema puede verse WIEACKER,F.: Historia del Derecho Privado de la Edad Moderna, edición al cuidado de J.L. Monereo Pérez, Granada, Ed.Comares (Col. Crítica del Derecho), 2000, Quinta Parte.

169Sobre las "condiciones" implícitas y explícitas de la "paz burguesa" en el espacio jurídico, véase ARNAUD, A.J.: Les origenes doctrinales du Code civil français, París, L.G.L.J., 1969.

170Sobre su concepción véase L'Expérience Juridique et la Philosophie Pluraliste du Droit, París, Pedone, 1935, y su obra principal GURVITCH, G.: L'Idée du Droit Social. Notion et Système du Droit Social, París, Sirey, 1932 (reimpresión alemana de la edición de París de 1932, Scientia Verlag Aalen-1972).

171 Aunque en algunos casos -sólo en algunos- se puede dar la razón a Jean Carbonnier cuando afirma que "el pluralismo cree haber filmado el combate de dos sistemas jurídicos y lo que nos muestra es un sistema jurídico en lucha con la sombra de otro". Cfr. CARBONNIER, J.: Sociología jurídica, trad. L.Diez-Picazo, Madrid, Ed. Tecnos, 1977, pág.123.

172Véase, para esa última calificación CARBONNIER, J.: Sociología jurídica, trad. L.Diez-Picazo, Madrid, Ed. Tecnos, 1977, pág.122. Este autor parece, sin embargo, ser refractario respecto a la admisión de un pluralismo en sentido fuerte (efectiva coexistencia plural de ordenamientos jurídicos en un mismo espacio social), y prefiere hablar de lo que denomina un "verdadero pluralismo jurídico" que él pretende encontrar en el "pluralismo judicial", habida cuenta de que el juez crea Derecho y que el problema de su fidelidad al Derecho positivo objeto de aplicación no se asegura en todo caso a través de los procedimientos de "unidad de 
El que se cuestionara el monismo jurídico y que perdiera peso frente a la emergencia de una multiplicidad de teorías pluralistas no fue sólo una exigencia de la doctrina jurídica, sino una exigencia de captación de la más amplia experiencia jurídica por parte de aquélla. Se ha dicho, con razón, que "el éxito de la teoría pluralista dependió del hecho de que daba una representación de la realidad social más satisfactoria, precisamente en el momento en el que la ebullición de las fuerzas sociales, consecuencia de la presión de la "cuestión social", amenazaba con hacer saltar -y en algunos países este salto se había producido- la tapadera del Estado"173.

Esta emergencia de la cuestión social, y la apertura hacia nuevas formas de creación jurídica (sobre todo ante la formación del Derecho social autónomo de los grupos organizados en el mundo del trabajo) no era sino un exponente de la crisis de la estatalidad del Derecho y con él de la quiebra del paradigma jurídico racionalista de la codifición estatalista174, basada en una idea de orden centralizado en el poder estatal como único poder jurídico formalizador de la sociedad civil175. En efecto, la codificación estatalista refleja el "sentido de la seguridad", el cual nacía de las estructuras profundas de la sociedad, donde la burguesía, victoriosa después de las revoluciones del diecinueve, era la clase dominante y dirigente, es decir, la élite portadora de una escala de valores, en la que toda la sociedad estaría llamada a reconocerse de modo indiferenciado176. A partir de ahí se descubren otras formas de creación jurídica extralegislativa, es decir, al margen del principio de soberanía estatal 177.

Sin embargo, es de destacar que Gurvitch no propuso una suerte de pluralismo "destructivo" o totalmente "disgregador", ya que a pesar de su antiestatalismo subyacente siempre pensó que el Estado tenía que asumir una función ordenadora de la sociedad y, por consiguiente, una función racionalizadora de la coexistencia de distintas fuentes de producción jurídica.

jurisprudencia" (Ibid.,pág.123). En realidad, Carbonnier no es un pluralista, quizás porque no aprecie la realidad de que el pluralismo interno, de que se ha hablado en el texto, sea en verdad también pluralismo integrado en el texto constitucional. Esta exclusión, no atendible desde mi punto de vista, le hace ver como meramente residuales las distintas manifestaciones del pluralismo jurídico en los sistemas jurídicos contemporáneos.

173BOBBIO, N.: "Teoría e ideología en la doctrina de Santi Romano", en Contribución a la teoría del Derecho, Valencia, Fernando Torres-Editor, 1980, pág.163. Sobre la vinculación entre la cuestión social y las doctrinas pluralistas, véase MONEREO PÉREZ, J.L.: Fundamentos doctrinales del Derecho social en España, Madrid, Ed. Trotta, 1996.

174Sobre la ruptura de ese paradigma de legislador racionalista, véase DUGUIT, L: Le droit social, le droit individuel et la transformation de l'etat, Paris, 1927, pág.233. [Existe traducción española La transformación del Estado, trad. seguida de un estudio sobre La nueva orientación del Derecho político por Adolfo Posada, Madrid, Francisco Beltrán-Librería Española y Extranjera, s/f. (1909)]. Estas obras están integradas en la edición crítica, DUGUIT, L.: Las transformaciones del Derecho Público y Privado, edición crítica y estudio preliminar, "'Objetivismo jurídico y teoría de los derechos en León Duguit” (pp. XI-XXXIX), a cargo de J.L. Monereo Pérez y J. Calvo González, Granada, Ed. Comares (Col. Crítica del Derecho), 2007.

175De manera que no podía identificarse ya las fuentes del Derecho con la soberanía estatal. En este sentido MENGONI, L.: "L' Europa dei codici o un codice per l' Europa?", en RCDP, núm.4 (1992), págs.515 y sigs., en particular pág.515. Véase, al respecto, ZAGREBELSCKY, G.: El derecho dúctil, Madrid, Trotta, 1995.

176Véase IRTI, N.: La edad de la descodificación, Barcelona, Ed. Bosch, 1992, pág.17.

177En este sentido CARNELUTTI, F.: La teoria del regolamento collettivo dei rapporti di lavoro, Padova, Cedam, 1932, pág.83. Igualmente realzando la ruptura que ha supuesto la verificación del pluralismo de las fuentes de producción jurídica o fuentes materiales, GURVITCH, G.: L'Expérience Juridique et la Philosophie Pluraliste du Droit, París, Pedone, 1935, pág.145. 
Gurvitch era perfectamente consciente de la necesidad de racionalizar el pluralismo efectivamente existente y del importante papel ordenador del ordenamiento estatal, cuya intervención es necesaria para mantener la cohesión de la sociedad organizada178. Pese a lo que en alguna ocasión ha podido afirmarse, Gurvitch no fue nunca un "anarquista" jurídico y social; sí pensó que la sociedad no tenía por qué asistir pasivamente a una ordenación desde el vértice centralista del Estado, sino que podía participar democráticamente en el proceso de formalización jurídica de la sociedad y asimismo establecer una coexistencia ordenada entre la función jurídica del Estado y la aportación de los diversos grupos sociales pertenecientes a la sociedad democrática. Postuló así la existencia de un círculo virtuoso en la producción legislativa en el interior de una verdadera sociedad democrática formalizada en una pluralidad de órdenes jurídicos autónomos en el interior de un mismo Estado nacional. En la época en que orientó las reflexiones Gurvitch existían muchas dificultades políticas y jurídicas para establecer las bases de un ordenamiento pluralista racionalmente reconducido hacia la unidad de valores y de funcionamiento de una sociedad compleja.

El pensamiento de Gurvitch está presidido por el intento de construir una nueva sociedad civil desde nuevas bases constitutivas, vertebrándola internamente para conseguir que todos los individuos participen activamente en la elaboración permanente del proyecto de sociedad democrática. En esa aspiración a refundar una nueva sociedad civil activa (ciudadanía activa) y en la defensa del pluralismo en todas sus más variadas dimensiones reside uno de los elementos explicativos del persistente interés contemporáneo por el pensamiento de Gurvitch. Pensaba que un sistema democrático auténtico exige una sociedad civil articulada a través de identidades colectivas y por grupos sociales independientes del Estado para la defensa de sus intereses y valores 179. Por ello mismo creía en un modelo democrático-social donde los individuos participaran en todos los ámbitos de la vida social, económica y política. Era necesario, pues, proceder a esa construcción de una nueva sociedad civil caracterizada por la presencia de grupos sociales autónomos respecto del poder público; grupos que gocen de un marco de garantías suficientes para actuar y facilidades, que configurarían un "estatus jurídico" en la sociedad democrática. Tales grupos pueden intervenir en el proceso de elaboración de las normas públicas, pero también pueden generar un derecho social autónomo para la autocomposición de sus intereses como reflejo de su autonomía social dentro de la Constitución ordenadora del sistema de convivencia. Por ello el Estado no puede pretender agotar toda posible expresión organizada de la sociedad civil y, lejos de ellos, debe potenciar la articulación de la sociedad. Los países democráticos deben, pues, aceptar como valor positivo la existencia de distintos modos de expresión

178No obstante, Gurvitch no participaría de la concepción pluralista de Santi Romano que acaba considerando el pluralismo en función servidora del Estado. Quizás porque, como hace notar Bobbio, Santi Romano "es teóricamente un pluralista pero ideológicamente un monista". Véase, al respecto, BOBBIO, N.:"Teoría e ideología en la doctrina de Santi Romano", en BOBBIO, N.: Contribución a la teoría del Derecho, Valencia, Fernando Torres, 1980, en particular págs.166 y sigs.

179Esta afirmación puede apreciarse en la obra colectiva O'DONNELL, G. y SCHMITTER, P. y WHITEHEAD, L. (eds.): Transitions form Authoritarian Rule, 4 vols., Baltimore, The John Hopkins University Press, 1986. 
colectiva. Es necesaria una constitución nueva de la sociedad civil para consolidar y fortalecer la democracia.

En el fondo Gurvitch defendía una progresiva reabsorción de funciones estatales en la sociedad civil. En la lógica de su pensamiento esencialmente ecléctico (derivado, como se vió, de las múltiples influencias de diverso signo, especialmente de la filosofía ética y social de pensadores tan distintos como Fichte, Proudhon y Marx) no propugnaba la desaparición del Estado, y de su sistema de Derecho unilateral, sino una descentralización colectiva e institucional de tareas públicas que serían realizadas en un régimen de autogobierno o autodeterminación social. Pensaba, asimismo, que el reconocimiento del derecho de participación, como derecho humano y de los grupos sociales, constituiría un antídoto frente a la tentación totalitaria del poder instituido. De este modo sería dentro de la sociedad civil dónde se establecerían las limitaciones del poder estatal mediante la generación de un nuevo Derecho, el Derecho Social, y la predisposición de mecanismos institucionales de participación activa de los individuos y grupos. La crisis de la democracia moderna se resolvía en un reforzamiento de los derechos sociales de ciudadanía (algo fácilmente deducible del "Proyecto de Declaración de los Derechos Sociales"). Es un redescubrimiento en términos integradores de la sociedad civil expresada a través del "Derecho social". De ahí su propuesta de sustituir el capitalismo organizado por el Estado -en el plano jurídico y político- por un régimen colectivista organizativamente descentralizado en el ámbito jurídico ("derecho social" autónomo) y político (elevación de las organizaciones colectivas a sujetos políticos). Gurvitch ve en este proceso democratizador y de homogenidad social la condición necesaria para la realización de la libertad humana. Más allá de su visión autogestionaria y libertaria alternativa al sistema capitalista, no se puede dudar de cierta actualidad de sus planteamientos (pluralismo jurídico y derecho social autónomo) cuando se asiste contemporáneamente a procesos de desregulación legislativa (disminución significativa del Derecho estatal intervencionista) y a la realización de políticas de Derecho estatal reflexivo que abren espacios y promueven directamente el Derecho autónomo de los grupos sociales. Es la paradoja del retorno de "lo social”, del "derecho social”, pero bajo nuevas formas y funcionalidades (muy significativamente la legitimación). Esto prueba igualmente la discontinuidad de "lo social" y, en estrecha relación a ello, de "lo jurídico e institucional" en el mundo moderno y contemporáneo180.

No obstante, con el constitucionalismo social contemporáneo es el texto constitucional quien acaso puede tratar de reducir hacia la unidad la pluralidad jurídica y social existente. Es en efecto, la Constitución la que establece las bases del sistema jurídico y con él la organización general de las fuentes del Derecho. Pero nuevamente ello es reflejo de una nueva fase, políticamente concertada, en la constitucionalización formal de la constitución realmente existente en las sociedades fragmentadas del capitalismo avanzado. Ahora bien, lo que no ha podido en la coyuntura actual resolver el constitucionalismo moderno situando

180 MONEREO PÉREZ, J.L.: Pluralismo jurídico y Derecho social: La sociología del Derecho de Gurvitch, Estudio Preliminar a la obra de GURVITCH, G.: Elementos de sociología jurídica, Granada, Editorial Comares (Col. Crítica del Derecho), 2001, págs. XIII-CXLVI., en particular págs. LXI-LXII. 
a la Constitución en el centro del universo jurídico181 es la emergencia de fuentes de producción extraestatal en el ámbito internacional, donde asistimos a una "explosión" de particularismos políticos y jurídicos en la era de la globalización. De manera que al pluralismo "interno" al Estado (con la crisis del principio de soberanía interna solventada en gran medida por la redefinición del pacto constitucional) se le añade el más difuso y complejo pluralismo "externo" en el ámbito supranacional (con la crisis del principio de soberanía estatal y de territorialidad de las fuentes de producción jurídica, que ya ha superado ampliamente las fronteras estrechas del Estado-nación182). Ese pluralismo "externo" determina que el Estado social no es capaz de integrar el policentrismo jurídico que se desenvuelve en el plano de la sociedad internacional.

De este modo el sistema jurídico esta constituido por un haz de sistemas jurídicos diversos que mantienen relaciones de naturaleza diversa, sobre la base de una separación relativa. Esto es así, a pesar de que la experiencia jurídica ponga de manifiesto la tendencia del ordenamiento jurídico estatal a estructurarse como un sistema cerrado y no abierto a los otros órdenes jurídicos como se derivaría de la configuración constitucional pluralista de los ordenamientos jurídicos contemporáneos183. Esta última dirección es la propia de la concepción pluralista coherente con una constitución que consagra un sistema pluralista en plano político y jurídico, lo que supone que coexisten diferentes sistemas jurídicos. Existe así un pluralismo institucional, que presupone la coexistencia de sistemas jurídicos de diverso tipo o naturaleza, en correspondencia con la existencia de una multiplicidad de grupos sociales organizados (a los cuales se reconoce autonomía social) o instituciones sociales184. Esa pluralidad de sistemas u órdenes jurídicos puede producirse dentro y fuera de cada ordenamiento jurídico particular: sistemas jurídicos estatales (unitarios, federales y federados), supraestatales (como es el caso de la Unión Europea), infraestatales (órdenes jurídicos de grupos sociales organizados y corporaciones), e incluso los sistemas jurídicos transnacionales o desterritorializados (órdenes jurídicos correspondientes a los grupos transnacionales de sociedades comerciales, orden jurídico eclesiástico)185. En el mundo cada vez más global se afirma el pluralismo en todas sus dimensiones.

\section{C) La defensa incondicionada del pluralismo jurídico y de la existencia de un "Derecho social" de carácter extraestatal.}

El fundamento del pluralismo jurídico de Gurvitch reside en su teoría de los "hechos normativos", la cual hace recaer el poder jurídico en todas las comunidades sociales capaces de crear Derecho. Es la teoría de los "hechos normativos" generadores de Derecho la base fundamentadora de la concepción pluralista de las fuentes del Derecho en el pensamiento de

\footnotetext{
181Véase, por todos, IRTI, N.: La edad de la descodificación, Barcelona, 1992, págs.17 y sigs. passim.

182Sobre ese paradigma político y sus fundamentos, véase la obra TIVEY, L.: El Estado Nación, Barcelona, Eds. Península, 1981, págs.25 y sigs.

183Sobre esta problemática general de los ordenamientos cerrados y abiertos, véase VIRALLY, M.: La pensée juridique, París, LGDJ, 1964, págs.200-201.

184BOBBIO, N.: Teoría general del Derecho, Madrid, Ed. Debate, 1991, págs.20 y sigs.

185Véase KERCHOVE, M.V. DE y OST, F.: El sistema jurídico entre orden y desorden, Madrid, Servicio de Publicaciones de la Facultad de Derecho de la UCM, 1997, págs.161 y sigs.
} 
Gurvitch. Para nuestro autor los hechos normativos se originan de modo espontáneo en las comunidades sociales y constituyen el Derecho social que sirve de expresión formal a dichas comunidades parciales186. Para Gurvitch, existen dos tipos de hechos jurídicos: "los hechos de la "relación con los otros" y de la sociabilidad por delimitación y ecuación; y por otro lado, los hechos de la unión y de la "sociabilidad por comunión e interpretación"". "Estos dos tipos de hechos normativos están unidos, a su vez, a dos tipos distintos de valores: los valores personales y los valores transpersonales187, y a los tipos distintos de Derecho: el Derecho individual y el Derecho social"188. Gurvitch realza el papel del Derecho social como tipo de hecho normativo, destacando los valores transpersonales que tienden a ser mejor realizados por el Derecho social. Éste constituye en lo esencial un Derecho transpersonal189, proyección de la integración democrática de los individuos en la sociedad pluralista (comunidad humana configurada como totalidad inmanente, al mismo tiempo reflejo de lo uno y de lo múltiple), por contraposición al Derecho individualista del pensamiento jurídico liberal.

Con todo, para Gurvitch tomar nota de la realidad existencial del pluralismo jurídico supone constatar que su campo es el propio de la lucha entre sistemas, fuerzas sociales y política, produciéndose siempre una tensión latente o manifiesta y alcanzándose sólo un equilibrio provisional entre los poderes sociales con potestad normativa creadora de Derecho que actúan en el mismo seno de la sociedad global.

186Es como dijera antes Ehrlich la emergencia del ordenamiento interno de los grupos sociales en el Derecho moderno. Véase EHRLICH, E.: I fondamenti della sociologia del diritto, Milano, Giufrè, 1976, págs.35 y sigs., quien, significativamente, había mantenido una noción análoga respecto a la teoría de los hechos normativos de Gurvitch (Ibid., págs.105 y sigs.).

187Respecto a la verificación del transpersonalismo como substrato filosófico en el pensamiento de Gurvitch, véase GURVITCH, G.: L'Expérience Juridique et la Philosophie Pluraliste du Droit, París, Pedone, 1935, págs.99 a 102; GURVITCH, G.: Proudhon. Su vida, su obra, su filosofía, trad.J.Marfá, Madrid, Eds. Guadarrama, 1974. Gurvitch intenta superar el individualismo realizando al individuo en la totalidad transpersonal, integrándolo como miembro en el "todo" social. Este transpersonalismo es una concepción ética muy particular, que sintetiza la oposición entre individualismo y universalismo en la idea de un flujo supraconsciente ("Noi") de creación pura, cuya materia está formada por una infinidad de conciencias que participan en la creación. Constituye un momento de equlibro entre libertad personal y totalidad social ("sociedad transpersonalista"); es decir, entre el "yo" (personalidad individual) y el "nosotros" (personalidad social o colectiva). En este sentido GURVITCH, G.: l’ Idée du Droit Social, cit., págs. 10 y sigs. Sobre el tema puede consultarse TOULEMONT, P.: "Il superamento fichtiano dell'individualismo in Gurvitch", en Riv. In.Fil.Dir., 1940; TOULEMONT, P.: Sociologie et pluralisme dialectique. Introduction à l'oeuvre de Georges Gurvitch, Lovain-París, Ed. Nauwelaerts, 1955. Véase, ampliamente, y con este análisis, MONEREO PÉREZ, J.L.: Pluralismo jurídico y Derecho social: La sociología del Derecho de Gurvitch, Estudio Preliminar a la obra de GURVITCH, G.: Elementos de sociología jurídica, Granada, Editorial Comares (Col. Crítica del Derecho), 2001, págs. XIII-CXLVI, en particular págs. LXIV-LXVII.

188Cfr.TREVES, R.: Sociología del Derecho, cit., págs.118-119

189Reténgase en esta visión del transpersonalismo la influencia determinante del idealismo social de Fichte. Véanse los estudios de GURVITCH, G.: Die Einheit der Fichteschen Philoso-phie. Personal und Gemeinschaftwert in der Ethik Fichtes. Eine Studie über Fichtes Lehre vom sittlichen Ideal. I. Lieferung, Berlin, Verlag A.Collignon, 1922; Ibid., Fichtes System der konkreten Ethik, Tübingen, Mohr, 1924. 
Un exponente del pluralismo social es el "derecho social obrero", el cual ha sido construido190 sobre base convencional entre los grupos sociales191 y sólo después ha sido recogido en la constitución jurídica formal y apoyado e impulsado a través de formas de Derecho estatal reflexivo o procedimental192. Esta forma de Derecho social autónomo de los grupos ha tenido una expansión extraordinaria reflejándose en una red de convenios colectivos que para Gurvitch constituían verdaderas "cartas constitucionales para toda una rama industrial". Subrayaba igualmente el reconocimiento de los convenios colectivos como fuentes de un nuevo Derecho objetivo193. Una afirmación, pues, del Derecho colectivo del trabajo194. Ese Derecho social colectivo refleja en sí mismo la mayor complejidad del Derecho contemporáneo, cada vez más diferenciado en su interior conforme la sociedad pluriclasista y multigrupal tiende a diferenciarse, fragmentándose y haciéndose más porosa. Esta forma de Derecho social tiene un carácter negocial, tendiendo a producirse a través de ella una descentralización jurídica de "lo social" y un pluralismo de las fuentes y técnicas normativas de regulación social, de manera que los confines entre sociedad y Derecho aparecen más discontinuos y porosos. Precisamente el surgimiento de esta forma de Derecho social extraestatal se percibiría como una manifestación de la tendencia centrífuga a la disgregación del poder central por la emergencia de los grupos socio-económicos reales. Esta forma de Derecho social sería una manifestación de la autodeterminación social en el Derecho (soziale Selbstbestimmung im Recht) en virtud de la cual las fuerzas sociales libremente organizadas producen un Derecho objetivo propio y autoadministrado195. Junto a ese Derecho social autónomo existe el Derecho social estatal derivado de la acción de los trabajadores sobre los poderes públicos196, que podría ser un instrumento para actuar y orientar los procesos de transformación del sistema social. Para Gurvitch, el Derecho social es un verdadero derecho de integración en la diversidad de la experiencia jurídica en un medio ambiente jurídico marcadamente post-positivista que acentúa la permeabilidad y porosidad de los distintos sistemas jurídicos197.

Para Gurvitch existen cuatro tipos diferentes de ordenamientos del derecho social, que completan la tipología jurídica de los grupos198: a) Ordenamientos del derecho social puro

190En el sentido de GÉNY, F.: Método de interpretación y fuentes en Derecho positivo, Est. preliminar sobre "El pensamiento científico-jurídico de Gény", a cargo de J.L. Monereo Pérez, Granada, Ed. Comares (Col. Crítica del Derecho), 2000. Gurvitch dedica interesantísimas reflexiones a la lucha de Gény contra el fetichismo de la ley y su teoría de lo "dado" y lo "construido" en el Derecho. Véase GURVITCH, G.: Le Temps présent et l'idée du Droit Social, París, ed. J.Vrin, 1932, Sección III, cap.I, págs.217 y sigs.

191Véase GURVITCH, G.: Le Temps présent et l'idée du Droit Social, París, ed.J.Vrin, 1932, págs.13 y sigs. 192Véase TEUBNER, G.: Le droit, un système autopoïétique, París, PUF, 1993.

193GURVITCH, G.: Le Temps présent et l'idée du Droit Social, París, ed.J.Vrin, 1932, págs.14-15 y ampliamente págs. 27 y sigs.

194Conectó en esa reafirmación con la doctrina E.Lévy, como puede comprobarse en otra obra importante del GURVITCH, G.: L'Expérience Juridique et la Philosophie Pluraliste du Droit, París, Pedone, 1935, págs. 170 y sigs.

195Véase SINZHEIMER, H.: Ein Arbeitstarifgesetz. Die Idee der sozialen Selbstbestimmung im Recht, 1916, pág.186.; Ibid., "La théorie des sources du droit et le droit ouvrier", en Annuaire de l'Institut International de Philosophie du Droit et de Sociologie Juridique, 1934, págs.73 y sigs.

196Véase RIPERT, G.: Les forces créatrices du droit, Paris, L.G.D.J., 1955, págs.249 y sigs.

197Véase GURVITCH, G.: Le Temps présent et l'idée du Droit Social, París, ed. J.Vrin, 1932, pág.26.

198Véase GURVITCH, G.: Elementos de sociología jurídica, cit., págs.196 y sigs. 
e independiente, superiores o equivalentes en caso de conflicto al orden del derecho estatal. b) Ordenamientos del derecho social puro, pero sometidos a la tutela estatal, es decir, que no disponen de coacción incondicionada y autónoma, pero que en caso de conflicto se inclinan ante el orden jurídico del Estado y le ceden el lugar. c) Ordenamientos del derecho social autónomo, pero anexado por el Estado, es decir, puestos a su servicio, ya sea por su incorporación a este último, como "servicios públicos descentralizados", ya sea por su simple elevación en el dominio privilegiado del derecho público. d) Ordenamientos del derecho social condensado en derecho del Estado.

\section{D) La teoría pluralista del Derecho en la sociedad contemporánea}

El pluralismo jurídico remite a la coexistencia de varios sistemas u ordenamientos jurídicos dentro de un espacio social determinado. Presupone la existencia simultánea de varios órdenes jurídicos con el Derecho estatal y con el Derecho emanado de las organizaciones internacionales. La existencia del pluralismo jurídico supone una multiplicidad de reglas jurídicas de origen diverso, diferentes instrumentos de poder y de formación de decisiones jurídicas y también de legitimidad jurídica. No es un fenómeno nuevo (piénsese en la coexistencia entre el Derecho colonial y el derecho "indígena"; y la siempre persistente coexistencia de distintas culturas dentro de un mismo ámbito geopolítico).

Interesa diferenciar el "pluralismo jurídico clásico", en el que predomina el tema de la coexistencia entre dos o más ordenamientos jurídicos continuamente contrapuestos, y el "nuevo pluralismo jurídico", en que, por el contrario, prevalece, el tema de la co-variación entre una multiplicidad de esferas jurídicas inestables y a menudo fragmentadas en el propio interior199. El nuevo pluralismo jurídico se corresponde con la complejidad inherente a las sociedades contemporáneas avanzadas, con la emergencia de nuevos actores económicos y sociales en el escenario interno e internacional. Un pluralismo que sólo transitoriamente ha podido ser simplificado a través de fórmulas de neocorporativismo negociado (corporativismo negociado). El neocorporativismo débil expresa, en este sentido, una toma en consideración de la revitalización del pluralismo socio-político en el marco del sistema de relaciones laborales200. Ante ello no puede negarse la utilidad metodológica del modelo pluralista para analizar los sistemas y órdenes jurídicos contemporáneos201.

El pluralismo actual encuentra manifestaciones distintas. Existe un pluralismo "interno" (en el mismo interior de un Estado-nación o sistema nacional) y un pluralismo "externo" (el que

199OLGIATI, V.: "Il pluralismo giuridico come lotta per il diritto (e la follia teorico-metodologica di una recente proposta)", en Sociologia del diritto, núm. (1994), pág.98; MERRY, S.E.: "Legal Pluralism", en Law \& Society Review, vols.22, núm.5 (1988).

200Una visión actualizada del problema puede encontrarse en MONEREO PÉREZ, J.L.: Concertación y diálogo social, Valladolid, Lex Nova, 1999, passim., y bibliografía allí citada; MONEREO PÉREZ, J.L. (Dir.) et altri: La concertación social en España: una evaluación de su trayectoria en la perspectiva de los cambios socioeconómicos, R. Álvarez Gimeno, Á. L. De Val Tena, J.A. Maldonado Molina, J.L. Monereo Pérez, M.N. Moreno Vida, R. Muñoz de Bustillo Llorente, Madrid, Ed. Consejo Económico y Social de España (Premio de Investigación del CES), 2015.

201Sobre el tema puede verse, en una perspectiva general, CORSALE, M.: "Alcuni nodi teorici del modello pluralistico", en Sociologia del diritto, núm.1 (1994), págs.15 y sigs. 
se produce dentro de unidades supranacionales y más ampliamente el que se intensifica y tiene lugar dentro del proceso de globalización de la economía mundial). En efecto, la fragmentación de la sociedad contemporánea, vinculada con la reorganización del capitalismo, deja espacios abiertos para nuevas formas de organización jurídica. Por un lado, internamente las sociedades contemporáneas se han conformado como sociedades muy fragmentadas, tanto por efecto del sistema de clases como por la multiplicidad étnica y cultural, lo cual ha supuesto una complejidad mayor de "lo social" y de "lo jurídico". Por otro, es lo cierto que la globalización produce una complejización de los mecanismos de poder jurídico. El Estado, de forma explícita o implícita, cede ámbitos de soberanía a instancias internacionales que son capaces de generar Derecho objetivo "extraestatal". Este fenómeno en las relaciones internas ("lex mercatoria"; Derecho informal...), unido a la formación de micro-sistemas jurídicos dentro del Estado, produce un redescubrimiento del pluralismo jurídico, aunque en términos más complejos que en el pasado.

En este contexto de "explosión" del pluralismo en el capitalismo global y de la complejidad de la regulación jurídica de las relaciones sociales resulta evidente la crisis de la concepción monista del Derecho202. La transformación del Derecho refleja esa porosidad y ambigüedad203 del Derecho contemporáneo. Un Derecho que desde la postguerra estuvo

202Triunfa así la gran intuición de Gény y Ehrlich, sobre la crítica del monismo estatalista y la existencia de fuentes de producción jurídica extraestatal. El mismo Gurvitch no renegará del papel garantista de derechos del Estado en una democracia social, pero hará un mayor enfásis en los poderes de autogobierno colectivo, teniendo en cuenta la experiencia propia de los consejos obreros de la revolución rusa en la cual había participado directamente, pero también la experiencia de los consejos de fábrica y la constitución del trabajo en la empresa que se había consagrado en la República de Weimar de la mano de su gran impulsor Hugo Sinzheimer, un autor también partidario del pluralismo y de la autorganización colectiva sobre la base del soporte de una democracia constitucional. Precisamente su propuesta de "Declaración de derechos sociales" está penetrada por ese espíritu de de autodeterminación social sobre la base de un apoyo garantista de la Constitución jurídica del Estado Social de Derecho. GURVITCH, G.: La Déclaration des Droits Sociaux, New York, Editions de la Maison Française, 1944 (ed. francesa, París, Librairie Philophique J.Vrin, 1946), reeditada en París, Dalloz, 2009. Véase, MONEREO PÉREZ, J.L.: Pluralismo jurídico y Derecho social: La sociología del Derecho de Gurvitch, Estudio Preliminar a la obra de GURVITCH, G.: Elementos de sociología jurídica, Granada, Editorial Comares (Col. Crítica del Derecho), 2001, págs. XIII-CXLVI; MONEREO PÉREZ, J.L.: Democracia pluralista y Derecho Social. La teoría crítica de Georges Gurvitch, Barcelona, Ediciones de Intervención Cultural/El Viejo Topo, 2021; MONEREO PÉREZ, J.L.: La democracia en crisis: Harold J. Laski, Barcelona, Ediciones de Intervención Cultural/El Viejo Topo, 2004; MONEREO PÉREZ, J.L.: "Democracia social y económica en la metamorfosis del estado moderno: Harold J. Laski", en Lex Social: Revista de Derechos Sociales, 11(1), 298-377 (2021). https://doi.org/10.46661/lexsocial.5426; MONEREO PÉREZ, J.L.: La defensa del Estado Social de Derecho. La teoría política de Hermann Heller, Barcelona, Ediciones de Intervención Cultural/El Viejo Topo, 2009; MONEREO PÉREZ, J.L.: La teoría jurídica y social de Otto von Gierke: Teoría del Derecho Social y de las personas colectivas, estudio preliminar a GIERKE, O. VON: La función social del Derecho privado y otros estudios, Trad. José M. Navarro de Palencia, revisión y edición a cargo de J.L. Monereo Pérez, Granada, ed. Comares (Col. Crítica del Derecho), pp. IX-LXI, 2015; MONEREO PÉREZ, J.L.: Estado y democracia en Otto Kirchheimer, estudio preliminar a KIRCHHEIMER, O.: El empleo de procedimientos legales para fines políticos, edición y estudio preliminar, a cargo de J.L. Monereo Pérez, Granada, Ed. Comares (Col. Crítica del Derecho), 2001, págs.17-185; MONEREO PÉREZ, J.L.: El Derecho en la democracia constitucional. La teoría crítica de Gustav Radbruch, Barcelona, Ediciones de Intervención cultural/El Viejo Topo, 2020. Es de interés el artículo del propio GURVITCH, G.: "Une philosophie antinomique du droit: Gustav Radbruch", en Archives de philosophie du droit et de sociologie juridique, II, 1932, págs. 530-563.

203De ambigüedad hablaba CAPOGRASSI, G.: "La ambigüedad del Derecho contemporáneo", en La crisis del Derecho, Buenos Aires, EJEA, 1961, págs.35 y sigs. 
marcado por el acrecentamiento del papel regulador del Estado204 coherente con el modelo de organización social fordista-keynesiano. Este modelo realzó -cerrando en gran medida el debate precedente desde los inicios del siglo veinte- el monismo jurídico estatalista, como modelo o vía de juridificación de las relaciones sociales205. En correspondencia con ello, el Estado del Bienestar se constituía en el centro de la producción jurídica (en el centro del sistema de fuentes del Derecho). Esta forma estatal se irrogaba el monopolio de la fuerza jurídicamente institucionalizada, en sentido maxweberiano206, subordinando jerárquicamente a otras fuentes jurídicas por él "ordenadas" en su desenvolvimiento vital. El Derecho del Estado imponía así su propia racionalidad jurídica a los demás órdenes jurídicos, garantizada la unidad en la diversidad y con ello la "dispersión" de los sistemas de regulación.

Pues bien, en el momento presente se constata la crisis de ese modelo de regulación (el modelo fordista-keynesiano) y una de sus manifestaciones es la potenciación de otros modelos de regulación social que exigen técnicas y reglas jurídicas diferentes: el Derecho procedimental, el Derecho reflexivo, el Derecho local y regional y otras formas del Derecho, que precisamente suponen que el Estado establece ciertas garantías jurídicas y abre espacios, y actúa de apoyo a la autonomía privada de los grupos sociales para la producción de Derecho autónomo. Esto da lugar a distintos y simultáneos modos de producción del Derecho, que no se construyen sobre una misma racionalidad jurídica ni tampoco actúan sobre los mismos espacios sociales. Son micro-sistemas jurídicos fragmentados que escapan al control monista del Derecho del Estado, que pierde en gran medida su tradicional centralidad, en favor de esas esferas jurídicas asimétricas e inestables. Estas nuevas formas de producción del Derecho coexisten en los ordenamientos nacionales y en el sistema pluriordinamental internacional y europeo y plantean una complejización de los procesos de legitimación jurídica. La crisis de la soberanía nacional es patente en los procesos de integración regional (señaladamente la Unión Europea como forma transnacionalizada de Derecho) y en la relativa pérdida de autonomía decisional del Estado frente a los poderes económicos 207.

204Ver Aglietta, Boyer, CORIAT, B.: Taller y cronómetro, México, siglo veintiuno, 1982; HARVEY, D.: Conditions of Postmodernity. An Enquire on the Origins of the Cultural Change, Cambridge, Mass, Basil Backwell, 1991. En la perspectiva de la doctrina jurídica, véase SANTOS, B.: "Sobre los modos de producción del derecho y el poder social", en Estado, Derecho y Luchas Sociales, Bogotá, ILSA, 1991, cap.5, págs.171 y sigs.

205La "juridificación" (Verrechtlichung) remite a la tendeicia que se aprecia en las sociedades modernas a un aumento creciente del Derecho formal o escrito. En dicha tendencia se puede diferenciar entre la "extensión" del Derecho, es decir, la regulación jurídica de nuevas materias o asuntos sociales regulados hasta ese momento de modo informal, y también el "adensamiento" del Derecho, esto es, la desmenuzación de una materia jurídica en distintas materias particularees. En este sentido HABERMAS, J.: Teoría de la acción comunicativa, t.II., Buenos Aires, Ed.Taurus, 1990, pág.504.

206Véase su obra monumental, WEBER, M.: Economía y Sociedad, México, FCE, 1983. Asimismo, WEBER, M.: Sociología del Derecho, que incluye también la "Sociología del Poder", edición y estudio preliminar, a cargo de J.L. Monereo Pérez, Granada, Ed. Comares (Col. Crítica del Derecho), 2001; WEBER, M.: Política y Ciencia y otros ensayos de sociología, trad. C. Correas, revisión, edición crítica y estudio preliminar, "Modernidad y racionalización del poder y del Derecho. La crítica de la razón instrumental en Max Weber", a cargo de J.L. Monereo Pérez, Granada, Ed. Comares (Col. Crítica del Derecho), 2011.

207Véase HELD, D.: La democracia y el orden global. Del Estado moderno al gobierno cosmopolita, 
El cambio del modelo de regulación jurídica está vinculado al proceso de globalización de la economía. El modelo fordista-keynesiano disponía de su propia estructura jurídicopolítica residenciada, ante todo, en la forma de Estado-nación, que ha constituido hasta la década de los setenta el mecanismo institucional de regulación jurídica del capitalismo contemporáneo. El Estado se situó en el centro de la regulación socio-económica y política, siendo su instrumento el Derecho estatal. El Derecho estatal intervencionista en los distintos ámbitos de la vida económica y social se asentó en el esquema de la racionalidad jurídica, formal y material, y en calidad de centro supremo de poder tendía a prevalecer sobre los demás centros de poder, constituyéndose en eje del sistema de fuentes de producción jurídica y encauzando hacia su propio ordenamiento estatal las fuentes "subordinadas". En sustancia, el Derecho intervencionista, configuró esencialmente un modelo específico de "monismo jurídico", que aunque no negaba la existencia de otros órdenes jurídicos en el mismo territorio (configurado así como monismo relativo interno208), tendía a juridificarlos e insertarlos de algún modo en el orden estatal, sometiéndolos a su propia lógica directiva y ordenadora. Es la lógica coherente con el Derecho racional moderno, con el proceso de racionalización occidental209, que tiene como consecuencia la emergencia de un tipo de

\section{Barcelona, Paidós, 1997.}

208Que, en realidad, se traducía más en el pluralismo de las fuentes jurídicas internas (pluralismo interno en el cuadro de un mismo ordenamiento jurídico) que en el pluralismo de los Derechos u ordenamientos jurídicos autónomos (pluralismo externo de Derechos en vigor).

209Véase HABERMAS, J.: Teoría de la acción comunicativa, t.I., Buenos Aires, Ed.Taurus, 1989, págs.197 a 350 ("La teoría de la racionalización de Max Weber"). Puede verse, aunque, es obvio, en una perspectiva distinta, la posición pluralista de VECCHIO, J. DEL.: "Sobre la estatalidad del Derecho, y La crisis del Estado", en Persona, Estado y Derecho, Madrid, CEC, 1957, págs. 361 y sigs., y 411 y sigs., para quien no todo Derecho es estatal. En este sentido considera que no puede ignorarse la existencia de varios sistemas u órdenes jurídicos dotados de autonomía: el Derecho de la Iglesia, el Derecho Internacional y el Derecho económico. Trata de demostrar la existencia de una espontánea productividad jurídica extraestatal, la cual puede llegar a ser un elemento fisiológico o patológico, beneficioso o perjudicial para el Estado mismo, según que éste sea o no capaz de dominarla y asimilarla. Por lo demás, entiende que "no ha de excluirse a priori, aun en esta materia, la posibilidad de fenómenos de divergencia y de antinomia entre las formaciones jurídicas autónomas y el ordenamiento estatal. La formación de agregaciones sociales con propios ordenamientos específicos, no conectados en su origen con el Estado tiene un carácter universal; porque toda unión social tiende naturalmente a engendrar un derecho propio, o mejor, tiene ya en sí (en cuanto sea una verdadera y propia unión social y no un simple caos), en una cierta manera, la forma lógica del derecho y continúa desenvolviendo sus normas de esta misma forma. Es bien cierto que ninguna convivencia y colaboración es posible entre individuos, sin una determinación, que pueda ser tácita siempre que sea efectiva, de la esfera de actividad que afecta a cada cual y, por consiguiente, de las obligaciones y de las facultades respectivas. Esta determinación puede, sin embargo, ser impuesta por un poder extraño y anterior, como algo ya formado e invariable (como cuando, por ejemplo, en un ejército se crea un nuevo regimiento) en cuyo caso sobreviene ipso facto, casi de modo autómático, la inserción del nuevo entre en el sistema preexistente, representado por aquel poder. Pero el caso más frecuente y, por decirlo así, fisiológico, es que los individuos no estén simplemente pasivos frente a las normas que deben gobernar la acción común, sino que procedan ellos mismos a plasmarla, aunque sea aprovechando los elementos de sistemas ya dados".

El problema de la fusión -escribe Del Vecchio- de estas varias organizaciones en la forma de una sola voluntad, continúa siendo el mismo que antes hemos considerado. Importa notar especialmente que la dependencia que se atribuye a todos los organismos sociales respecto del ordenamiento jurídico del Estado, se resuelve a menudo en una simple fictio juris, porque existen en realidad organismos sociales que viven jure propio, permaneciendo unidos al Estado sólo por nexos extrínsecos o por genéricas relaciones, que no afectan a la estructura y no destruyen la autonomía de su ordenamiento intrínseco. Que no obstante este ordenamiento tenga naturaleza jurídica, se deduce con rigor de la presencia de los caracteres... (propios del Derecho). No podría negarse tal naturaleza por la presunta imposibilidad de un derecho no estatal, sin incurrir en el error de una petitio principii, 
acción social que se diferenció de la tradicional: la acción racional con arreglo a fines, imperante en las sociedades de mercado. A partir del siglo XVI existe un proceso de institucionalización de la acción racional con arreglo a fines, que introduce transformaciones estructurales en la sociedad global. Para Max Weber los dos procesos institucionales en que se materializan los procesos de racionalización social son la economía capitalista y el Estado moderno, donde se produce la concentración de los medios materiales de organización conforme al cálculo racional210. La estatalización jurídica del Derecho en Estado moderno tuvo como efecto inicial un intento de reducción de todo Derecho al Derecho estatal, con la consiguiente supresión del pluralismo211. Es así como el Derecho constituye el medio de organización de la sociedad capitalista moderna; del paradigma propio de la racionalidad instrumental se transitó hacia la racionalidad funcional, como segunda fase estructural del proceso de racionalización occidental en la cual el Derecho deviene en un procedimiento formal212. Ya en los esquemas funcionalistas y, especialmente, en la racionalidad sistémica de Luhmann, el sistema jurídico asume una función de control de las relaciones sociales, del mercado de trabajo y del consumo, fundamenta la legitimidad del poder y sanciona negativamente el comportamiento desviante 213.

Tras la crisis de ese modelo de los setenta, se produce un replanteamiento del modelo fordista del Estado nacional contemporáneo. Desregulando ámbitos de intervención en el marco de políticas esencialmente (neo)liberales214, que serían ocupados por otros poderes jurídicos, y potenciando los mecanismos de integración transnacional, con el surgimiento de nuevas

o sea de un círculo vicioso (Ibid., págs. 387 a 389). Por otra parte, sin perjuicio de su autonomía relativa, es posible que existan ordenamientos jurídicos que tengan una esfera propia de acción separada (por ejemplo, la de dos Estados diversos); pero también de ordenamientos jurídicos que se interfieren, que tienen vigencia (al menos en parte) en el mismo territorio y para los mismos sujetos.

210Véase WEBER, M.: Economía y Sociedad, México, FCE, 1987, págs.648 a 660. Sobre el pensamiento de Weber en este sentido, véase HABERMAS, J.: Teoría de la acción comunicativa, t.I., Buenos Aires, Ed.Taurus, 1989, págs.286 y sigs. Puede consultarse GIDDENS, A.: El capitalismo y la moderna teoría social, Barcelona, Ed. Labor, 1977, Tercera Parte ("Max Weber"); FREUND, J.: Sociología de Max Weber, Barcelona, eds. Península, 1986. Para la sociología de Max Weber, consúltase FARIÑAS DULCE, M.J.: La Sociología del Derecho de Max Weber, Madrid, Civitas, 1991.

211Véase, "in fine", WEBER, M.: Economía y Sociedad, cit., pás.40 y sigs.

212Véase, nuevamente HABERMAS, J.: Teoría de la acción comunicativa, t.II., Buenos Aires, Ed.Taurus, 1990, págs.281 a 426 ("Talcott Parsons: problemas de construcción de la teoría de la sociedad").

213Véase la exposición de BÜLLESBACH, A.: "Enfoque de teoría de sistemas", en KAUFMANN,A.y HASSEMER,W.(Ed.): El pensamiento jurídico contemporáneo, Madrid, Ed.Debate, 1992, pág.325.

214Pero no se olvide que ya desde los orígenes de las políticas liberales de "laissez faire" se comprendió la necesidad de la intervención Estatal en toda política de organización de la sociedad moderna. Hizo notar lúcidamente Dicey que "sinceros creyentes de laissez faire descubrieron que para lograr sus metas, el mejoramiento y fortalecimiento de la maquinaria gubernamental eran una necesidad absoluta". En realidad, las políticas de laissez faire se realizaron a través de una intervención sistemática del Estado, garantizando el desenvolvimiento de la actividad económica y social. Cfr. DICEY, A.V.: Lectures in the Relation between Law and Public Opinion in England during the Nineteenth Century, Londres, MacMillan, 1905, pág.306. DICEY, A.V.: Lecciones sobre la relación entre Derecho y opinión pública en Inglaterra durante el siglo XIX, trad. y estudio preliminar de M. Salguero e I. Molina Martín, Granada, Ed. Comares (Col. Crítica del Derecho), 2007.

Un ejemplo significativo, aparte de los ya conocidos de la disolución legal de las comunidades agrarias y gremiales que estructuraban la solidaridad grupal, es la condena a muerte hecha por Colbert a los trabajadores que emigraron de Francia para trabajar de forma asalariada en el extranjero. Cfr. ADLER, A.: Zuchthaus und Fabrik, Leipzig, Ernst Oldenburg Verlag, s/f.,págs.72-73. 
formas de Derecho distintas al Derecho del Estado de corte clásico. El Estado-nación pierde peso como instancia de regulación jurídica, aunque la situación actual es la propia de un período de transición y coexistencia entre distintos modelos de regulación. La sociedad contemporánea es el reino de la diversidad y de la flexibilidad (formas diversas de organización del proceso productivo estructuradas a través de reglas emanadas de la negociación colectiva como modo de producción del Derecho social autónomo de los grupos 215; nuevos procesos de estratificación social -infraclase...-; coexistencia de distintas culturas históricas; proliferación de colectividades emigrantes en los países desarrollados; resistencia de comunidades a la aplicación del Derecho dominante, en el plano interno e internacional, etcétera) y esa misma heterogeneidad facilita la proliferación de diferentes tipos de regulación jurídica que hacen competencia al Derecho estatal. De este modo, las relaciones económicas y sociales quedan penetradas por una red de heterogéneos órdenes jurídicos configurando su efectiva constitución jurídica.

Frente a la ciencia del Derecho liberal existen en la sociedad distintos modos de juridicidad o formas de Derecho, donde el Derecho del Estado es una de las formas, de ordinario la dominante. Ha de partirse, pues, de la pluralidad de Derechos u ordenamientos jurídicos que coexisten entre sí en la experiencia jurídica216. Existe una multiplicidad de espacios jurídicos diferentes a los cuales corresponden varias formas distintas de Derecho: el derecho local, el derecho nacional (los sistemas de Derecho de los Estados-nación), el derecho mundial (señaladamente la nueva "lex mercatoria", espacio jurídico internacional basado en la práctica de los actores económicos en las relaciones de comercio mundial217) y el derecho comunitario (el Derecho formal de la Unión Europea, ejemplo típico de "polisistemia normativa" donde el Derecho comunitario se diferencia respecto a los ordenamientos internos nacionales)218. Ese pluralismo jurídico refleja la existencia, junto al "Derecho geocéntrico" de la edad moderna (sistema de derecho formal, general y abstracto, presidido por una racionalidad formal)219, de nuevas formas de "Derecho egocéntrico", como

215Véase MONEREO PÉREZ, J.L.: "Teoría jurídica del convenio colectivo: su elaboración en la ciencia del Derecho", estudio preliminar a GALLART FOLCH, A.: Las convenciones colectivas de condiciones de trabajo, Granada, Ed.Comares (Col. Crítica del Derecho, 2000, págs.XI a CLXIII. Asimismo, GIUGNI, G.: Introducción al Estudio de la Autonomía colectiva, traducción y estudio preliminar, "La teoría de la autonomía colectiva en el pensamiento de Giugni: Balance y perspectivas" (pp. IX-CXXVII), a cargo de J.L. Monereo Pérez y J.A. Fernández Avilés, Granada, Ed. Comares (Col. Crítica del Derecho), 2004.

216Aparte de la bibliografía clásica, al respecto, véase FITZPATRICK, P.: "Law, Plurality and Underdevelopment", en SUGARMAN, D. (Coord.): Legality, Ideology and the State, Londres, Academic Press.

217La "lex mercatoria" es la expresión formal de una práctica realizada por actores particulares, al margen de los ordenamientos estatales. Véase DEZALAY, Y.: Marchands de droit. La restructuration de l'ordre juridique international par les multinationales du droit, París, Fayard, 1992; MONEREO PÉREZ, J.L: La metamorfosis del Derecho del Trabajo, Albacete, Ed. Bomarzo, 2017, espec., Capítulo II.2., págs. 54 y sigs. MONEREO PÉREZ, J.L.: "La racionalización jurídica de las relaciones laborales y la emergencia de nuevas fuentes reguladores en el orden internacional", en Lex Social. Revista jurídica de los Derechos Sociales, vol. 8, núm. 1 (Enero-Junio 2018), págs. 1-44.

218En una perspectiva general, consúltese SANTOS, B. DE S.: Estado, Derecho y luchas sociales, Bogotá (Colombia), ILSA, 1991, pág.223. Para el Derecho comunitario, véase ARNAUD, A.J.: Pour une pensée juridique européene, París, PUF, 1991, págs.20 y sigs.

219Sobre esa distinción, véase WEBER, M.: Economía y Sociedad, México, FCE, 1983. Sólo matizar que para Weber el derecho personal o particularista ("derecho egocéntrico") tenía una vigencia totalmente residual 
derechos particularistas elaborados en el seno de los propios grupos sociales y pensado para su aplicación en su "espacio interno". De manera que "lo jurídico no puede ser reducido a un sistema de derecho en vigor en un lugar y en un momento dado", sino a una multiplicidad de espacios jurídicos que se interpenetran dinámicamente y de modo permanente220. De ahí la superposición de sistemas jurídicos autónomos en un mismo espacio ("pluralismo"), que se entremezclan dinámicamente entre sí, perdiendo a menudo su "pureza" y dando lugar al surgimiento de fronteras difusas entre los órdenes jurídicos coexistentes (interlegalidad)221. Es así que en los ordenamientos jurídicos de las sociedades contemporáneas tienen una estructura compleja (donde existen sistemas y subsistemas jurídicos autónomos) y coexisten y se superponen con otros ordenamientos externos en un sistema-mundo cada vez más integrado e interdependiente.

El pluralismo jurídico puede ser formal y admitido dentro de un sistema jurídico general o puede ser una realidad jurídica informal paralela y no inserta en el Derecho oficial dominante; es decir, como fenómeno jurídico no reconocido por el Derecho dominante. Esa constatación, y su comprensión en términos de pertenencia al fenómeno jurídico (y no meramente al dato sociológico general), supone una ampliación de la noción de Derecho y responde a una visión más compleja de la sociedad contemporánea como sociedad jurídica, intensamente regulada por el Derecho.

El pluralismo de Derechos u órdenes jurídicos puede ser débil o de segundo grado (basado en la existencia de relaciones jerárquicas o de dominación entre los Derechos que coexisten), o fuerte o de primer grado (el cual trata simétricamente a los diversos órdenes jurídicos coexistentes)222. Ha existido, y existe hoy bajo nuevas formas de expresión, una lucha por el reconocimiento efectivo del pluralismo jurídico dentro y fuera de los Estados nacionales. Se ha hablado al efecto de una "lenta conquista del pluralismo jurídico" frente a los intentos de supresión o sometimiento desde el poder público institucional223. Se trata verdaderamente de una nueva lucha224 por el Derecho plural en una democracia abierta, que no puede sino conducir al reconocimiento de la autonomía jurídica de las comunidades y de los grupos sociales en el seno de cada país y en el plano internacional; evitando el proceso de uniformización que puede entrañar un modelo autoritario de globalización del

y subordinada al Derecho general del Estado. Sin embargo, la experiencia jurídica contemporánea muestra la persistencia de estas formas de Derecho consideradas "antiguas" y la emergencia de otras nuevas.

220ARNAUD, A.J.: Critique de la raison juridique. 1. Oú va la Sociologie du droit?, París, Librairie Génerale de Droit et de Jurisprudence, 1981, pág.23.

221Véase SANTOS, B. DE S.: "Droit: une carte de la lecture déformée. Pour una conception post-moderne du droit", en Droit et Societé, núm.10 (1988), págs.363 y sigs.

222En este sentido SORIANO, R.: Sociología del Derecho, Barcelona, Ariel, 1997, pág.362., obra, ésta, en la que se recoge una interesante exposición general del pluralismo jurídico contemporáneo (Ibid., págs.359 y sigs.).

223En este sentido, véase SORIANO, R.: Sociología del Derecho, cit., págs.364 y sigs.

224De lucha por el Derecho habla OLGIATI, V.: "Il pluralismo giuridico come lotta per il diritto (e la follia teorico-metodologica di una recente proposta)", en Sociologia del diritto, XXI, 1994, 1, págs.97 y sigs. En el ámbito de la memoria jurídica resulta inevitable la continuidad de pensamiento como la conocida obra de IHERING, R. Von.: La lucha por el Derecho, trad.A.Posada, edición y estudio preliminar, "Ihering y la lucha por el Derecho" (pp. VII-XXXI), a cargo de J.L. Monereo Pérez, Granada, Ed. Comares (Col. Crítica del Derecho), 2008. 
Derecho. Ese pluralismo fuerte opera en el Derecho internacional, reflejo de la pluralidad de ordenamientos de los países de la sociedad internacional. Pero en los ordenamientos jurídicos internos de cada Estado Nación el pluralismo fuerte suele ser más teórico que real, porque en cada espacio sociopolítico existe un Derecho dominante (que suele ser precisamente el Derecho del Estado) que mantiene la unidad del ordenamiento jurídico estructurado como un poli-sistema jurídico abierto. En otros casos es la Constitución jurídica la que organiza la pluralidad de los ordenamientos jurídicos internos por ella construidos. Sin embargo, el poder político hegemónico, en el ámbito nacional e internacional trata de neutralizar la existencia de otros órdenes de Derecho autónomos o alternativos a los principios de organización dominantes, reconduciéndolos y subordinándolos al orden hegemónico establecido.

Con todo, la experiencia jurídica contemporánea muestra la coexistencia y superposición tanto en un mismo espacio geopolítico como en varios espacios jurídicos entremezclados de varios órdenes jurídicos autónomos o relativamente autónomos. Se trata de formas porosas de Derecho constituidas por una multiplicidad de redes o mallas de órdenes jurídicos en continuo cambio y adaptación a las contingencias de la vida social y de los grupos y comunidades sociales. De tal manera que el "sistema" jurídico (nacional e internacional) adquiere la conformación interna de un poli-sistema jurídico, de conformación altamente heterogénea y fragmentada, como corresponde a las sociedades complejas, en su interior, y en un medio ambiente "externo" (sólo en sentido metafórico) de la sociedad de la globalización donde se interpenetran y articulan, de modo formal o informal, distintos órdenes jurídicos potencialmente o realmente autónomos. La característica del pluralismo contemporáneo es también la "interlegalidad", es decir, la dimensión fenomenológica225 del pluralismo jurídico: "se trata de un proceso altamente dinámico porque los diferentes espacios jurídicos no son sincrónicos y por eso también las mezclas de códigos de escala, de proyección o de simbolización son siempre desiguales e inestables. La mezcla de códigos es visible en todos los procesos sociales" en los que se manifiestan diferentes modos de producción jurídica226. Esa fragmentación de "lo jurídico" está, como no podría ser de otro modo, íntimamente ligada a la fragmentación de la realidad social en la que se insertan las distintas formas de producción del Derecho. Estamos ante un universo jurídico poli-céntrico, donde todavía se siente el peso dominante de los ordenamientos estatales modernos sobre los restantes órdenes jurídico a distinto nivel, incluido en el ámbito del Derecho internacional. Pero es preciso llamar la atención sobre la crisis estructural de toda forma de pensamiento jurídico monista: el pluralismo jurídico es un fenómeno empíricamente

225Repárese en que en ciertos aspectos la concepción del Derecho que desarrolló Gurvitch en la década de 1930 está influida por la fenomenología de Husserl -junto con las corrientes de pensamiento, como la tradición de la escuela de Durkheim, y señaladamente de su discípula más destacado Marcel Mauss-, entendiendo que el Derecho es un fenómeno social total inserto en la realidad integral de la sociedad. Más adelante, en su última época, Gurvitch se distanciaría de la fenomenología, como resulta patente en su obra GURVITCH, G.: La vocation actuelle de la sociologie, Paris, PUF, 1955, v. 1, págs. 66 y sigs. Existe traducción castellana, GURVITCH, G.: La vocación actual de la sociología, México D.F., Fondo de Cultural Económica, 1953, edición posterior de 1970.

226SANTOS, BOAVENTURA DE S.: Estado, Derecho y luchas sociales, Bogotá (Colombia), ILSA, 1991, pág. 237. 
verificable que obliga a pensar de modo distinto el Derecho de manera que la centralidad de los ordenamientos jurídicos de carácter público no impida constatar la existencia de órdenes jurídicos autónomos antiguos y nuevos que han emergido ante la complejidad de la sociedad contemporánea y la coexistencia y yuxtaposición de Derecho u órdenes jurídicos derivada de los procesos de fragmentación interna e interdependencia internacional. Lo cual exige adoptar una racionalidad plural y compleja en la comprensión de los factores que impulsan la dinámica de las sociedades jurídicas como sociedades eminentemente pluralistas227.

En el plano científico hay que reconocer que ha tenido al respecto un papel relevante la sociología del Derecho, la cual pudo superar las tendencias más rígidamente formalistas y monistas seguidas por las corrientes doctrinales dominantes y mayoritarias en la ciencia jurídica.

Puede constatarse hoy la significación intrínsecamente política de la teoría del pluralismo jurídico. No cabe duda que en una sociedad democrática en la que existe una diversidad de clases y grupos sociales (sociedades fragmentadas, plurinacionales, pluriétnicas228 y multiculturales229) en su interior se impone un "pluralismo razonable"230, donde coexisten y se superponen doctrinas distintas en el marco de una cultura tolerantes y una red de instituciones democráticas. Tras ello se aprecia los distintos modos de distribución del poder y de originación de los conflictos sociales. En esta sociedad democrática pluralista, el interés general es determinado en cada momento como busqueda de una política de criterios de justicia para todos los participantes231. Ese pluralismo político y jurídico "razonable" (en la

227Se ha hablado en esa línea de pensamiento de la policentralidad, la cual "designa la multiplicidad de centros de decisión jurídica en un determinado sistema, lo que excluye la estructura piramidal del Derecho diseñada por Kelsen, en la que se basan muchos de nuestros órdenes jurídicos contemporáneos". Cfr. ARNAUD, A.J. y FARIÑAS DULCE, M.J.: Sistemas jurídicos: elementos para un análisis sociológico, cit., pág.292, quienes, por otra parte, apuntan al Derecho europeo como un Derecho policéntrico, formado, por un lado, por el Derecho comunitario, y por otro el que se crea en el marco de las organizaciones europeas (Ibid., pág.294).

228Respecto a la presencia y yuxtaposición en la sociedad multiétnica de ordenamientos extra-estatales, en situación alternativa o en conflicto con los sistemas estatales, véase FACCHI, A.: "Pluralismo giuridico e società multiétnica: proposte per una definizione", en Sociologia del diritto, núm.1 (1994), págs.47 y sigs., y bibliografía allí citada; GARCÍA, S. y LUKES, S. (Comps.): Ciudadanía: justicia social, identidad y participación, Madrid, Siglo XXI, 1999, Segunda Parte.

229El multiculturalismo está en la base del pluralismo internacional. Se ha señalado que "las sociedades modernas tienen que hacer frente cada vez más a grupos minoritarios que exigen el reconocimiento de su identidad y la acomodación de sus diferencias culturales, algo que a menudo se denomina el reto del "multiculturalismo"". Ese multiculturalismo supone la existencia efectiva de distintos tipos de derechos colectivos (derechos de autogobierno, derechos poliétnicos y derechos especiales de representación). Cfr. KYMLICKA, W.: Ciudadanía multicultural. Una teoría liberal de los derechos de las minorías, Barcelona, Ed. Paidós, 1996, pág.25.; KYMLICKA, W.: "Derechos individuales y derechos de grupos en la democracia liberal", en ÁGUILA, R. DEL y VALLESPÍN, F.: La democracia en sus textos, Madrid, Alianza Editorial, 1998. Puede verse también GRIFFITHS, J.: "What Is Legal Pluralism?", en Journal of Legal Pluralism and Unofficial Law, núm.24 (1986), págs.1 y sigs.; LUCAS, J. DE.: "Pluralismo jurídico, multiculturalismo y conflicto de derechos", en BERGALLI, R. (ed.): El desarrollo y las aplicaciones de la sociología jurídica en España, Oñati, Instituto Internacional de Sociología del Derecho, 1995.

230Al menos al estilo de pensamiento de John Rawls. Cfr. RAWLS, J.: Political Liberalism, New York, Columbia University Press, 1993, espec. págs.133 a 172. (existe traducción castellana de esta obra).

231Agrégese que para Gurvitch "el Derecho representa un ensayo de realizar, en un marco social determinado, la justicia (es decir, una reconciliación previa y esencialmente variable de las obras de civilización 
medida en que todo Derecho es siempre reflejo o manifestación de una opción política previa) tiene la finalidad de conseguir un consenso entrecruzado (overlapping consensus), sobre el cual se basa la propuesta rawlsiana de una democracia "consensual-constitucional", siendo así que dicho "consenso entrecruzado" constituye el instrumento procedimental que asegura una convivencia política democrática232. Es éste un liberalismo procedimental pluralista acorde con la complejidad de las sociedades contemporáneas, que son existencialmente pluralistas, lo cual exige un "consenso constitucional" entre las fuerzas y grupos sociales operantes en la sociedad.

Los ciudadanos en la sociedad democrática pluralista participan del interés común de mantener instituciones que establezcan un equilibrio reflexivo y dinámico en la sociedad, es decir, un principio de justicia concertada públicamente, como "razón pública" que es por su naturaleza mutable, sometida a alteraciones constantes que modifican el consenso originario233. El equilibrio reflexivo no tiene sólo una dimensión colectiva, sino que se proyecta sobre la exigencia de que la identificación de la voluntad general no suponga una neutralización de la propia identidad de los grupos y de los individuos, los cuales (unos y otros, voluntad colectiva y autonomía individual), deben tener la posibilidad efectiva de expresar libremente su posición respecto a los términos del equilibrio aceptados ("consensuados")234. Esa concepción de Rawls conduce hacia un modelo dinámico de construcción jurídico-social del Derecho, y no sólo en el ámbito estatal, sino también en otros espacios de producción jurídica; produciéndose una concurrencia (conflictiva o no) y superposición de diversos órdenes jurídicos de construcción de la realidad normativa235.

en contradicción) por imposición de encadenamientos multilaterales entre pretensiones y deberes, cuya validez deriva de hechos normativos, que portan en sí mismos la garantía de la eficacia de las conductas correspondientes". Cfr. GURVITCH, G. (Dir.): Traité de sociologie, t.II., $4^{\mathrm{a}}$ ed., París, PUF, 1962. Antes se había expresado en términos similares, cuando afirmaba que el Derecho es un orden positivo que representa un ensayo de realizar en un medio social determinado la Justicia (en tanto que conciliación previa de valores transpersonales y personales a base de logicización del ideal moral, aunque ella sirve de medio indispensable y dado a priori) por un conjunto de reglas multilaterales de carácter imperativo-atributivo, que instituyen una interdependencia estrictamente determinada entre deberes y pretensiones correspondientes, derivando su fuerza obligatoria de "hechos normativos", y admitiendo en ciertos casos la posibilidad de ser efectuada por imposición, sin exigirla necesariamente. Cfr. GURVITCH, G.: L'Idée du Droit Social, cit., pág.111.

232Véase RAWLS, J.: Political Liberalism, cit., págs.133 y sigs. En una perspectiva más amplia, GERARD, PH.: Droit et democratie: réflexions sur la légitimé du droit dans la société démocratique, Bruxelles, Publications des Facultés Universitaires Saint-Louis, 1995, págs.103 y sigs.

233En este sentido, básicamente, RAWLS, J.: Political Liberalism, cit., págs.221 y sigs. Véase también GUTMANN, A. (Ed.): Multiculturalism, Princeton University Press, 1994; DWORKIN, R.: Ética privada e igualitarismo político, Barcelona, Ed.Paidós, 1993; PETTIT, PH.: Republicanismo. Una teoría sobre la libertad y el gobierno, Barcelona, Paidós, 1999: GARCÍA, S.y LUKES, S. (Comps.): Ciudadanía, justicia social, identidad y participación, Madrid, Siglo XXI, 1999.

234RAWLS, J.: Teoría de la justicia, México, FCE, 1978, págs. 460 y sigs. Entiende Rawls que "el liberalismo político da como hecho un pluralismo razonable como un pluralismo de doctrinas comprehensivas, tanto religiosas como no religiosas. No considera ese pluralismo de la razón humana en contextos institucionales perdurablemente libres". Cfr. RAWLS, J.: El liberalismo político, Barcelona, Ed. Crítica, 1996, pág. 20.

235Sobre el tema puede consultarse NINO, C.: El constructivismo ético, Madrid, CEC, 1989, págs.91 y sigs.("El constructivismo epistemológico: entre Rawls y Habermas") 
En la sociedad pluralista, que conduce en coherencia hacia un pluralismo político y jurídico, se produce así una nueva forma de legitimidad basada en un procedimiento jurídico de elaboración consensuada de las decisiones. De este modo en un régimen constitucional el poder político es efectivamente "poder público", es decir, el poder de ciudadanos libres e iguales en tanto cuerpo colectivo que influye en las decisiones de gobierno236.

En una posición distinta, pero próxima a la Rawls, Habermas propone un paradigma procedimental del Derecho y un modelo normativo de democracia participada237. En el Estado social y democrático de Derecho se produce un equilibrio de poder jurídico entre los distintos grupos sociales; ese equilibrio deviene en pluralismo. En las sociedades contemporáneas la pluralidad de culturas y la estratificación social entraña una fragmentación interna que hace difícilmente gobernables a dichas sociedades, siendo el Derecho un elemento de integración social a través de la búsqueda de un consenso sobre las decisiones y del fomento de la promoción en la implicación directa de los actores sociales. El Estado constitucional se construye sobre la base de fomentar la integración social mediante la estabilización de expectativas y la realización de objetivos colectivos. De ahí que la legitimidad democrática encuentre su base última en el "mundo de la vida". Precisamente la "sociedad civil" está compuesta por asociaciones, organizaciones y movimientos que emergen más o menos espontáneamente, y, estando atentos a la resonancia de los problemas sociales en las esferas de la vida privada.

El corazón de la sociedad civil comprende una red de asociaciones que institucionalizan discursos de resolución de problemas sobre cuestiones de interés general en el marco organizado de las esferas públicas238. En su interior compiten entre sí varios sistemas de creencias, valores e intereses. En una moderna sociedad civil diferenciada, y por consiguiente compleja, existe un pluralismo consustancial que se expresa a través de una multiplicidad de canales que vinculan el mundo de la vida con la esfera pública. El mundo de la vida está integrado por una pluralidad de sujetos colectivos que expresan su opinión pública, encontrándose ello en la génesis democrática del Derecho contemporáneo. En este sentido la legitimidad del sistema democrático se mide por su capacidad integradora, siendo la teoría discursiva de la democracia constitucional la institucionalización de procedimientos comunicativos para la formación de voluntad discursiva y la producción legislativa legítima239. Es evidente que ello se orienta -o puede orientarse- hacia la participación en la

236Véase RAWLS, J.: Political Liberalism, New York, Columbia University Press, 1993, pág. 136. Para Rawls la política de consenso universal reside en el respeto a los derechos humanos, el cual condiciona todo ordenamiento jurídico democrático. Véase RAWLS, J.: "How a social contract doctrine is universal in its reach", en "The Law of Peoples", en SHUTE, S.y HURLEY, S. (Eds.): On Human Rights, New York, Basie Books, 1993, págs.68 y sigs.

237HABERMAS, J.: Facticidad y validez. Sobre el derecho y el Estado democrático de derecho en términos de teoría del discurso, Madrid, Ed. Trotta, 1998.

238Cfr. HABERMAS, J.: Facticidad y validez. Sobre el derecho y el Estado democrático de derecho en términos de teoría del discurso, Madrid, Ed. Trotta, 1998, cap.VII ("Política deliberativa") y cap.VIII ("Sobre el papel de la sociedad civil y de la opinión pública").

239HABERMAS, J.: Facticidad y validez. Sobre el derecho y el Estado democrático de derecho en términos de teoría del discurso, Madrid, Ed. Trotta, 1998, capítulos VII, VIII y IX. 
producción legislativa pública, pero también, y de modo complementario, hacia el pluralismo jurídico de los grupos sociales en presencia en la sociedad civil. En esto puede residir el paradigma de una democracia consensual, donde el poder comunitativo de la sociedad civil sea un factor esencial para determinar los contenidos de los valores superiores del sistema jurídico pluralista (libertad, igualdad, democracia y solidaridad). Este modelo es compatible con ciertas formas de autoorganización descentralizada de la sociedad. Sin que la política del Derecho quede centrada exclusivamente en el Estado. He aquí que la sociedad civil es la base social de los espacios públicos autónomos. Al "concepto discursivo de democracia" responde "la imagen de una sociedad descentrada que, sin embargo, con la diferenciación que en ella se produce de un espacio para la opinión pública política, diferencia de sí un espacio para la percepción, identificación y tratamiento de problemas concernientes a la sociedad global"240. Agrégese, sin embargo, el riesgo de la disolución de la comunidad jurídica en sociedades funcionalmente diferenciadas, caracterizadas por tratarse de sociedades policéntricas de grandes organizaciones de intereses y de coexistencia de distintas formas de producción jurídica, que determina una transferencia del poder político y jurídico a actores colectivos 241 .

En este marco, en el proceso de juridización de las relaciones sociales se ha dado apertura al Derecho reflexivo donde el Derecho estatal remite la solución de los conflictos al poder autónomo de los grupos sociales242, contribuyendo a acentuar el pluralismo jurídico "interno" al sistema jurídico. Se genera así un dualismo básico entre Derecho estatal y Derechos autónomos243. No obstante, el Derecho reflexivo presupone una combinación entre el poder estatal y el poder autónomo de los grupos, porque el Derecho reflexivo constituye una nueva forma de racionalización del sistema jurídico, donde las fuentes de regulacion no se encuentran en principio en posición de conflicto. Esa forma de Derecho procedimental es el producto de una visión pluralista de las diferencias existentes en el seno de la sociedad civil entre individuos y grupos; y es también reflejo de la búsqueda de un equilibrio entre las diversas posiciones existentes244. Para la perspectiva pluralista es importante constatar que la transferencia de competencias de decisión forma parte de los

240HABERMAS, J.: Facticidad y validez. Sobre el derecho y el Estado democrático de derecho en términos de teoría del discurso, Madrid, Trotta, 1998, pág.377, quien, por otra parte, subraya que "la idea de soberanía popular remite en su lectura procedimentalista a las condiciones sociales marco que posibilitan la autoorganización de una comunidad jurídica" (Ibid., pág.378).

241 Véase, en general, BOBBIO, N.: El futuro de la democracia, Barcelona, Planeta-Agostini, 1994, passim.

242Véase TEUBNER, G.: Le droit, un système autopoïétique, París, PUF, 1993.

243Véase BOHMAN, J.: "Complexity, pluralism, and the constitutional state", en Law and Society Review, vol.28, number 4 (1994), págs.897 a 930; OUTHWAITE, W.: Habermas: A Critical Introduction, Stanford, Stanford University Press, 1994, págs.137 y sigs.

244Hace notar Joshua Cohen que "la noción de una democracia deliberativa está enraizada en el ideal intuitivo de una asociación democrática en la que la justificación de los términos y condiciones de la asociación tiene lugar a través de la argumentación y del razonamiento público entre ciudadanos iguales. En tal orden los ciudadanos comparten el compromiso de resolver los problemas de elección colectiva mediante el razonamiento público y tienen a sus instituciones básicas por legítimas en la medida en que éstas establecen un marco para la deliberación pública libre". Cfr. COHEN, J.: "Deliberation and Democratic Legitimacy", en HAMLIN, A.y PETTIT, B. (eds.): The Good Polity, oxford, 1989, págs.17 y sigs., citada por HABERMAS, J.: Facticidad y validez, cit., pág. 381 . 
mecanismos de institucionalización de los procedimientos de política deliberativa245. Pero no se olvide que en la concepción de Georges Gurvitch preside más la idea de una democracia participativa "desde abajo", y no tanto la idea de un democracia deliberativa que en su concepción más estricta conlleva una selección del pluralismo de las organizaciones de intereses en su interlocución ("intercambio político") con el Estado y otros poderes públicos.

Con todo, en la sociedad se produce una "circulación del poder", a través de espacios públicos autónomos capaces de resonancia suficiente como para que los conflictos que existen en la "periferia" se transfieran al sistema político. La teoría clásica del pluralismo se basaba en una noción esencialmente empirista del sistema jurídico, participando de un entendimiento instrumental de la política, de manera que el poder político institucionalizado sólo es una forma más de manifestación del poder social global en las sociedades complejas246. En ellas las fuerzas de los intereses organizados pueden influir sobre la formulación de las políticas públicas y ostentar ciertos ámbitos de autoorganización social. En efecto, en la concepción liberal originaria el modelo ideal de la sociedad democrática era el de una sociedad centrípeta; sin embargo, la sociedad contemporánea actual es una sociedad centrífuga, en la que no existe un sólo centro de poder, sino una multiplicidad de ellos: es una sociedad policéntrica o poliarquía (o la democracia representativa moderna)247. Las sociedades democráticas actuales no son sociedades monistas, sino sociedades pluralistas, donde coexisten y se entrecruzan la representación política y las representaciones de los intereses organizados en el proceso de decisión política y jurídica (señaladamente en el fenómeno de la concertación social248). Las sociedades pluralistas actuales son "democracias de equilibrio" en el sentido formulado por C.B. Macpherson249.

Georges Gurvitch había planteado - dentro de su defensa de un socialismo democrático y pluralista- que la instauración de una sociedad socialista no suponía una pretendida superación del pluralismo social, jurídico y político. La nueva sociedad tendría que cambiar las estructuras institucionales tanto en la gestión de la economía general como en la gestión de la empresa en un sentido más democrático y realmente pluralista. El pluralismo sería un fundamento teórico y sociológico de la relación entre sociedad y gobierno, esto es, la

245Véase HABERMAS, J.: Facticidad y validez, cit., págs.405 y 407 y sigs.

246HABERMAS, J.: Facticidad y validez, cit., pág.439 y sigs.

247Véase BOBBIO, N.: El futuro de la democracia, cit., pág.27. Sobre la sociedad policéntrica o poliarquía, véase ampliamente, la obra ya clásica de DAHL, R.A.: La poliarquía. Participación y oposición, Madrid, Tecnos, 1997; y la reafirmación y actualización de sus posiciones en La democracia y sus críticos, Buenos Aires, Paidós, 1992. Se ha apostado, desde un punto de vista esencialmente pluralista, por una "democracia consensual" o "democracia consociacional". En este sentido LIJPHART, A.: Democracy in Plural Societies. A Comparative Exploration, New Haven, Yale University Press, 1977 (trad. española, México, Eds. Prisma, 1988).

248Véase MONEREO PÉREZ, J.L.: Concertación y diálogo social, Valladolid, Lex Nova, 1999, passim. En particular sobre los pactos sociales como manifestación típica de la concertación social, véase la excelente obra de MORENO VIDA, M.N.: Los pactos sociales en el Derecho del Trabajo, Granada, Universidad, 1989, passim.

249MACPHERSON, C.B.: The Life and Times of Liberal Democracy, Oxford, Oxford University Press, 1977.; Id.: MACPHERSON, C.B.: Ascenso y caida de la justicia económica y otros ensayos (1985), cap.8 ("Pluralismo, individualismo y participación"), Buenos Aires, Eds. Manantial, 1991, págs.117 y sigs. 
democracia supone la participación social y la participación política. De ahí la necesidad de la constitución democrática de todas las instituciones del orden de la sociedad: el ámbito económico, social, político y jurídico, cultural y educativo. Esto implica aceptar la autonomía y la capacidad decisoria de los individuos y grupos sociales en un proceso constinuo de transformación cualitativa de la sociedad y de su orden democrático250. Desde el campo del socialismo democrático se había afirmado que la democracia social considera al individuo en su interdependencia social, indisoluble con los demás individuos, como miembro de una colectividad. Esta concepción está sobre la teoría del socialismo, sobre la socialización de la vida humana; conduce prácticamente a la realización del socialismo, en tanto que socialización consciente de la vida humana251. Ciertamente, para caminar en esa dirección deberá superarse la obsoleta mentalidad del mercado totalizador de la vida humana, lo cual exige que la civilización debe encontrar un nuevo modelo de pensamieno y de acción252. Esto implicaría de suyo una nueva constitución para la empresa en una sociedad democrática en la que los trabajadores tuviesen un papel activo en su gestión y pudieran ejercer sus derechos de ciudadanía; y ello acompañado con las formas de intervención ordenadora y planificadora de la acción pública.

Sin embargo, la "democracia competitiva" se ha asentado sobre supuestos que la experiencia ha debilitado. Trataba de "proyectar sobre el plano de la distribución política del poder el equilibrio social del poder, de modo que la política estatal puede proveer equilibradamente e imparcialmente a un ancho espectro de intereses sociales". Pero en la teoría política, lo que ha quedado es una "teoría de las élites, limpia de aditamentos pluralistas, que reduce en lo esencial el proceso democrático a una elección plebiscitaria entre cuadros de líderes que compiten unos con otros" 253.

En la sociedad pluralista los individuos y los grupos que se encuentran en interacción dentro de la misma mantienen relaciones tanto de cooperación como de conflicto, y a través de ellas participan en la construcción de la comunidad jurídica y política254. En el orden social pluralista los grupos y asociaciones que los vertebran generan un impulso imperioso hacia

250 Dejando a salvo las experiencias anteriores en la República de Weimar, o en la autogestión yugoslava, por ejemplo, este modelo de democratización podría estar en conexión finalista con el ensayado en Suecia. Véase MEIDNER, R.: Capitale senza padrone. Il Progetto svedese per la formazione collettiva del capitales, Roma, EL edizioni lavoro, 1980, que planteaba una alternativa de democracia económica y la constitución de fondos de inversión de los trabajadores, como complemento de un sistema de planificación económica estatal (Ibid., págs. 45 y sigs., y 69 y sigs.). En otra perspectiva, WEITZMAN, M.L.: La economía de participación, trad. E. L. Suárez, Madrid, FCE, 1987, págs. 9 y sigs.

251 ADLER, M.: Democracia política y democracia social, trad. V. Pujolar, México D.F., Ed. Roca, 1975, pág.66.

252 POLANYI, K.: Nuestra obsoleta mentalidad de mercado, en POLANYI, K.: La esencia del fascismo. Seguido de Nuestra obsoleta mentalidad de mercado, edición, traducción y estudio introductorio de C. Ruiz Sanjuán, Madrid, Escolar y Mayo Editores, 2013, págs. 83 y sigs.

253HABERMAS, J.: Facticidad y validez, cit., pág.410.

254Véase, en general, DAHL, R.A.: La poliarquía. Participación y oposición, Madrid, Ed. Tecnos, 1997, para el la "poliarquía" es la maximización del proceso democrático. Según Dahl "cabría considerar las poliarquías como regímenes relativamente (pero no completamente) democráticos; o, dicho de otra forma, las poliarquías son sistemas sustancialmente liberalizados y popularizados, es decir, muy representativos a la vez que francamente abiertos al debate público" (Ibid., pág.18). 
la autonomía, lealtades internas y de grupo, siendo los conflictos inevitables que surjan dirimidos a través de una red de sistemas de negociación y convenios, que contribuyen a establecer una cultura política con normas que legitiman la misma negociación y obtengan el consenso de forma opuesta a los métodos de coacción o del ejercicio del poder de manera unilateral o monista estatal. Para Dahl no debe existir un único centro de poder soberano, sino que tiene que haber muchos centros, ninguno de los cuales debe poder ser completamente soberano. Esa existencia de una multiplicidad de centros de poder se considera que ayudará a controlor el poder, a asegurar el necesario consenso de todos y a resolver pacíficamente los conflictos que surjan en todo momento mediante acuerdos transaccionales. Un régimen basado en un orden social pluralista consolidado permite que la gran masa de la población tenga acceso al debate público; es decir, en el pensamiento de Dahl (de adscripción pluralista), que sea una "poliarquía"255.

El desarrollo del orden social pluralista conduce a que sus miembros y organizaciones deseen participar en las decisiones a través de fórmulas que se adaptan más al sistema político competitivo que al "hegemónico" o unidireccional. La concepción pluralista de Dahl se proyecta también sobre la democracia económica. Su argumentación es inequívocamente pluralista: si la democracia -afirma- se justifica para el gobierno del Estado, entonces también se justifica para gobernar empresas económicas. Lo que es más, si no se puede justificar para gobernar empresas económicas, no vemos como puede justificarse para gobernar el Estado. Los miembros de cualquier asociación para quienes los presupuestos del proceso democrático son válidos, tienen derecho a gobernarse a sí mismos por medio del proceso democrático. $\mathrm{Si}$, como es posible pensar, dichos presupuestos tienen validez entre nosotros, no sólo para el gobierno del Estado sino también para el gobierno interno de las empresas económicas, entonces tenemos el derecho de gobernarnos democráticamente dentro de nuestras empresas económicas. Por cierto, no se espera que la introducción del proceso democrático en el gobierno de las empresas económicas las convierta en perfectamente democráticas o que superen las tendencias hacia la oligarquía que parecen ser inherentes a todas las grandes organizaciones humanas, incluido el gobierno del Estado. Pero tanto como se apoya el proceso democrático en el gobierno del Estado a pesar de las sustanciales imperfecciones en la práctica, de igual manera apoyamos el proceso democrático en el gobierno de las empresas económicas a pesar de las imperfecciones que supondrá su ejecución. En consecuencia, no se ven razones convincentes por las cuales no se debiera ejercer el derecho al proceso democrático en el gobierno de las empresas, al igual que como ya se ha hecho en el gobierno del Estado. $\mathrm{Y}$ se pretende ejercitar dicho derecho256.

Sin embargo sólo se puede hablar de posibilidad de una democracia pluralista participada que emerge en los Estados democráticos occidentales, pero es evidente que el sistema

255Véase DAHL, R.A.: La poliarquía, cit., págs.78-79. Sobre las condiciones favorables a la poliarquía, véase págs. 181 y sigs.

256DAHL, R.A.: Prefacio a la democracia económica (1985), Buenos Aires, Grupo Editor Latinoamericano, 1990, págs.130-131. 
político de los Estados está lejos de ser participativo, aunque para la predominante teoría empírica pluralista esto pueda ser considerado como aceptable desde la perspectiva de una reforma gradualista257.

Hay que tener en cuenta las distintas dimensiones del pluralismo. Se puede hablar de varias teorías o corrientes pluralistas en el siglo veinte258: el pluralismo religioso, el pluralismo humanista y neoidealista de los siglos XIX y XX (J.S.Mill, T.H.Green, Ernest Barker, A.D.Linsay y Robert MacIver), el pluralismo de productores del anarco-sindicalismo europeo y del socialismo de guilda inglés (G.D.H.Cole y el primer Laski), el pluralismo anarquista comunitario, el pluralismo pragmático (John Dewey), el pluralismo liberal contemporáneo (Isaiah Berlin; John Rawls), el pluralismo norteamericano contemporáneo (Bentley, Truman, Schumpeter, Dahl, Almond, Verba y Berelson), el pluralismo libertario conservador (Milton Friedman, Hayek)259. Se ha podido decir, aunque quizá con excesiva generalización, que todos los tipos contemporáneos de pluralismo son extensiones de alguna forma del individualismo liberal. Suelen partir de una noción del "individuo como ser moralmente autosuficiente que busca -y está bien que lo haga- su propia satisfacción, sea como consumidor de utilidades o como alguien que ejerce y desarrolla sus potencialidades"260. Pero siendo ello sustancialmente cierto, es difícil que esa generalización pueda proyectarse efectivamente a todas las formas jurídicas de pluralismo jurídico contemporáneo261. Interesa anotar que el pensamiento de Gurvitch está penetrado por esas diversas corrientes pluralistas, y señaladamente por el federalismo social y el pluralismo jurídico de Proudhon262.

257Véase, recientemente, PETTIT, PH.: Republicanismo. Una teoría sobre la libertad y el gobierno, Barcelona, Paidós, 1999, espec., capítulo 6, págs.225 y sigs.

258Según Macpherson "el pluralismo, como práctica y como teoría, es claramente más propio de los estados democráticos liberales, y antitético a los estados de partido único. Y puede demostrarse fácilmente que la teoría justificativa del pluralismo tiene sus raíces en alguna forma del individualismo liberal: yo propondré que el pluralismo es individualismo en sentido amplio". Cfr. MACPHERSON, C.B.: Ascenso y caida de la justicia económica y otros ensayos (1985), cap.8 ("Pluralismo, individualismo y participación"), Buenos Aires, Eds. Manantial, 1991, pág.117.

259Una exposición sobre cada una de estas teorías véase en MACPHERSON, C.B.: Ascenso y caida de la justicia económica y otros ensayos (1985), cap.8 ("Pluralismo, individualismo y participación"), Buenos Aires, Eds. Manantial, 1991, págs. 117 y sigs.

260Cfr.MACPHERSON, C.B.: Ascenso y caida de la justicia económica, cit., pág.121.

261Es discutible que ese modo de pensar pueda ser aplicado respecto de algunas manifestaciones del pluralismo jurídico (que como resulta notorio tiene una dimensión política inherente a toda cosmovisión jurídica, a toda teoría jurídica). Es el caso precisamente del pluralismo jurídico-político de Gurvitch, que contrapone la idea individual a la idea social, para quien la idea individual realiza el esquema de pensamiento iusliberal individualista, mientras que la idea social incluye, en oposición a aquélla, una serie de direcciones de pensamiento distintas. La idea social remite al individuo situado en grupos sociales de pertenencia y en relación con la lógica de la acción colectiva interna al grupo mismo. Véanse sus obras fundamentales ya citadas, especialmente GURVITCH, G.: L'Idée du Droit Social. Notion et Système du Droit Social, París, Sirey, 1932, passim. Sobre el transfondo iusfilosófico de la distinción "idea individual" e "idea social", véase ampliamente SOLARI, G.: Filosofía del Derecho privado, vols. I ("La idea individual") y II ("La idea social"), Buenos Aires, Ed. Depalma, 1946 y 1950, respectivamente.

262Véase, especialmente, GURVITCH, G.: L'Idée du Droit Social. Notion et Système du Droit Social, París, Sirey, 1932 (reimpresión alemana de la edición de París de 1932, Scientia Verlag Aalen-1972); GURVITCH, G.: L'Expérience Juridique et la Philosophie Pluraliste du Droit, París, Pedone, 1935; GURVITCH, G.: Le Temps présent et l'idée du Droit Social, París, ed. J.Vrin, 1932; GURVITCH, G.: Elementos de sociología 
Por otra parte, desde el punto de vista del pluralismo político, la mayoría de las organizaciones de intereses carecen de los factores base de poder 263 frente al Estado o poder público para hacer valer eficazmente sus posiciones264. Esto supone que las perspectivas de instaurar un sistema pluralista participativo parecen ciertamente débiles, salvo que se introduzcan cambios relevantes en las relaciones de poder en el interior de las sociedades democráticas de base capitalista. En este sentido se ha subrayado la oportunidad de introducir un mayor control del poder público sobre las actividades privadas con base en la mayor dependencia de la economía respecto de la regulación pública y de la socialización pública de gastos y riesgos empresariales. Esta envoltura del Estado en la economía le otorga un nuevo poder sobre los capitales particulares (Habermas, Offe, O'Connor, Wolfe, Axel Honneth)265. En este contexto puede existir un "pluralismo inverso: el Estado puede pluralizar al capital", matizando fuertemente el modelo de sociedad capitalista utilizado por la corriente principal de los teóricos pluralistas norteamericanos266. Pero para el funcionamiento de un "pluralismo desarrollista" o avanzado, la orientación de las políticas de fondo estatales deberían abandonar el modelo individualista posesivo del hombre y evolucionar así hacia una democracia auténticamente participativa que permite un consenso pluralista sobre el proyecto de sociedad democrática a construir. Al respecto puede tener sentido la delegación de competencias estatales de tipo legislativo en sistemas de negociación que permita la afluencia dinámica del sentir de la sociedad. Ahora bien, "cuanto más son actores colectivos, es decir, subsistemas sociales y grandes organizaciones y no individuos, los que actúan, tanto más claramente se desplaza la base de imputación de consecuencias de la acción y tanto menos parecen poder venir asegurados por medio de derechos subjetivos los bienes colectivos de la "sociedad del riesgo" que se consideran dignos de ser protegidos jurídicamente" 267.

En realidad, las sociedades complejas democráticas requieren que la idea del Estado constitucional se generalice a toda la sociedad y promueven la garantía de la autonomía de los individuos y de los subsistemas sociales (actores colectivos). Es poner en práctica la idea de una constitución consensualmente institucionalizada en todos los ámbitos de la vida

jurídica, cit..

263Sobre esa noción véase GEIRGER, TH.: Estudios preliminares de sociología del Derecho, con una introducción y una bibliografía internacional a la sociología del derecho por Paul Trappe, traducción de Arturo Camacho, Guillermo Hirata y Ricardo Orozco; edición al cuidado de J.L. Monereo Pérez, Granada, Ed. Comares (Col. Crítica del Derecho), 2001.

264No es el caso propiamente de las grandes organizaciones de intereses sindicales que a través sobre todo de la huelga (que puede constituir un arma para la paralización de servicios vitales para la economía y el funcionamiento de la Administración pública) -y en menor medida mediante su influencia en la opinión públicapueden ejercer una presión relevante sobre las orientaciones de las políticas de gobierno. Véase MONEREO PÉREZ, J.L.: "La huelga como derecho constitucional: La técnica específica de organización jurídicoconstitucional de la huelga" (I) y (II), en Temas Laborales, núm.27-28 (1993); MONEREO PÉREZ, J.L. y ORTEGA LOZANO, P.: El derecho de huelga. Configuración y régimen jurídico, Cizur Menor (Navarra), Ed. Thomsom Reuters/Aranzadi, 2019.

265 HONNETH, A.: Crítica del poder, trad. G. Cano, Madrid, Ed. Antonio Machado, 2009.

266En este sentido MACPHERSON, C.B.: Ascenso y caida de la justicia económica y otros ensayos (1985), cap.8 ("Pluralismo, individualismo y participación"), Buenos Aires, Eds. Manantial, 1991, pág.125.

267HABERMAS, J.: Facticidad y validez, cit., pág.429. 
social, que se extienda a sus organizaciones y actores colectivos268. El problema práctico que se puede plantear es la dispersión que distorsionaría la idea de la "unidad múltiple" ante la proliferación de sistemas paraestatales de negociación y producción jurídica que carecen de vínculos efectivos con el régimen parlamentario, lo que puede producir un problema de legitimación del orden social pluralista269.

En esta línea de pensamiento hay que tener en cuenta que la sociedad civil se integra de asociaciones, organizaciones y movimientos. Efectivamente, el núcleo de la sociedad civil está constituido por una trama asociativa que institucionaliza los discursos encaminados a resolver problemas, relativos a cuestiones de interés general, en el marco de espacios públicos dotados de una mayor o menor organización270. Ese entramado social, esa base asociativa, constituye el sustrato organizativo de ese público general de ciudadanos que emana del ámbito privado y que busca interpretaciones públicas para sus intereses sociales influyendo sobre la formación institucionalizada de la opinión pública y la decisión política. Esa sociedad civil fragmentada abarca una pluralidad de organizaciones que determina que aquélla no constituya una masa informe de individuos aislados. Por ello se ha podido afirmar, con razón, que "la trama asociativa sólo puede conservar su autonomía y su espontaneidad en la medida en que pueda apoyarse en un sólido pluralismo de formas de vida, de subculturas y de orientaciones en lo concerniente a creencias"271. El paradigma procedimental del Derecho exige, y presupone el pluralismo: "la intención rectora sigue siendo la de domesticar el sistema económico capitalista, es decir, la de "reestructurarlo" social y ecológicamente por una vía por la que simultáneamente quepa "refrenar" el empleo de poder administrativo, es decir, quepa "entrenar" a éste desde puntos de vista de efectividad y eficacia en formas moderadas de regulación y control indirectos, así como reconectarlo retroalimentativamente con el poder comunicativo desde puntos de vista de legitimidad, inmunizándolo al propio tiempo contra el poder ilegítimo"272.

El paradigma procedimental y pluralista del Derecho no se basa en la potenciación de una única forma de Derecho (como el "derecho reflexivo"273), porque la elección de la forma de Derecho más conveniente dependerá de la lógica del problema a resolver y de la garantía más efectiva del sistema de derechos fundamentales. En este orden de ideas se podrá utilizar -e incluso combinar- la lógica formal (siempre necesaria al Derecho como técnica de organización social específica), la lógica material o la lógica reflexiva, dando lugar a las correspondientes formas de Derecho (derecho formal, derecho material y derecho reflexivo). La lógica del Derecho reflexivo puede encontrar un paradigma original en el caso de la autonomía social de los grupos organizados en el mundo del trabajo, en la que las asociaciones de intereses pueden celebrar convenios colectivos. El ejercicio de dicha autonomía social representa una estructuración interna de un sistema de acción no estatal

268HABERMAS, J.: Facticidad y validez, cit., pág.429.

269Véase HABERMAS, J.: Facticidad y validez, cit., pág.432.

270HABERMAS, J.: Facticidad y validez, cit., pág.447.

271HABERMAS, J.: Facticidad y validez, cit., pág.449.

272HABERMAS, J.: Facticidad y validez, cit., pág.492.

273Véase TEUBNER, G.: Le droit, un système autopoiétique, París, PUF, 1993. 
construido para la solución de los conflictos vinculados al trabajo asalariado. Para ello el ordenamiento jurídico atribuye facultades de creación de Derecho vigente. Aquí el Derecho estatal reflexivo abre espacios de regulación a la regulación colectiva autónoma, trasfiere facultades y articula normas de organización y garantía del libre desenvolvimiento de la autonomía colectiva negocial. Se trata, pues, de una regulación que favorece la autonomía jurídica de los grupos sociales.

En el último tercio del siglo veinte se pensó en la crisis irreversible del sistema del pluralismo político debido al auge de lo que se dió en llamar neocorporativismo o corporativismo democrático. La muerte o decadencia, según los casos, del modelo de corporativismo "marcroeconómico" originario ("macrocorporativismo") ha situado el problema en los términos de la sociedad pluralista. Ese paradigma corporativista ha mostrado ser al tiempo una respuesta transitoria y de tipo coyuntural a una fase específica de la evolución del capitalismo, caracterizada por la suavización de los conflictos de clase en el período de la reconstrucción de la postguerra (lo que se ha de vincular con el modelo de Estado del Bienestar keynesiano), y por la configuración todavía relativamente autónoma de las economías de los Estados nacionales. Como es sabido, las soluciones keynesianas han mostrado sus límites como vía para la administración eficiente del capitalismo contemporáneo y las políticas basadas en ellas entraron en decadencia. Lo cual no supone que el corporativismo negociado (que presupone una negociación entre clases a través de los grupos mayoritarios o las grandes organizaciones de intereses) no pueda tener juego en un ámbito o nivel inferior, sin perjuicio de la presencia del "macroporativismo" cuando las circunstancias de la gobernabilidad político-social requieran un nivel de respuesta más general274. El predominio de estas formas de corporativismo ha sido sustituido por la prevalencia de formas de nivel medio (el llamado "mezzo-corporativismo" o "corporativismo intermedio"), lo que supone reclamar ámbitos sociales de agregación media (grupos sociales específicos que pueden alcanzar acuerdos sectoriales o regionales o subnacionales).

Es así que el pluralismo democrático ha puesto de relieve su persistencia e incluso su revitalización, a pesar de los límites del paradigma pluralista. El declive del modelo corporativista es paralelo al auge del pluralismo como expresión del proceso contradictorio de democratización de la sociedad contemporánea, el cual conlleva la pluralidad de los intereses y las exigencias de articulación representativa275. La sociedad actual muestra como se asiste continuamente al surgimiento de nuevas formas de agregación de intereses en el seno de las democracias pluralistas, donde los grupos sociales mantienen una estrategia de influencia política más diversificada y descentralizada.

274Puede verse SCHMITTER, P.y LEHMBRUCH, G. (comp.): Neocorporativismo, México, Alianza Editorial, 1992; MORENO VIDA, M.N.: Los pactos sociales en el Derecho del Trabajo, Granada, Universidad de Granada, 1989. Para el declive actual de la regulación triangular centralizada, véase MONEREO PÉREZ, J.L.: Concertación y diálogo social, Valladolid, Lex Nova, 1999, y BELLARDI, L.: Concertazione e contrattazione, Bari, Cacucci Editore, 1999.

275Véase DAHL, R.: La democracia y sus críticos (1989), Buenos Aires, Paidós, 1992. 
La constitución jurídica del Estado social y democrático de Derecho desemboca hacia ciertos ámbitos de autoregulación de la sociedad, que se expresan en formas de Derecho viviente nacidas de los grupos sociales276. En realidad, "una sociedad está articulada y constitucionalizada cuando se confronta consigo misma en las adecuadas formas institucionales y procesos normativamente dirigidos de adaptación, de resistencia y de autocorrección"277. Ello es plenamente coherente con el paradigma procedimental del Derecho en los términos formulados por Habermas278.

\section{E) Pluralismo, derecho social y pensamiento social de la Iglesia}

El pensamiento social cristiano remite a la existencia de un espacio autónomo de lo social279. Tampoco Gurvitch permaneció ajeno a la influencia del pensamiento social cristiano, como muestran sus reiteradas citas de apoyo a la obra de J.Maritain280. Se ha insistido en una perspectiva general en la nota del pluralismo como una de las peculiaridades fundamentales del ordenamiento de la Iglesia281.

El pluralismo socialcristiano parte de una concepción esencialmente organicista de la sociedad: "es organicista por el hecho de que ve a los varios grupos sociales disponerse en orden jerárquico, cada uno recibiendo su dignidad por la función que desempeña, según su orden y grado, en todo"282. Para la doctrina social de la Iglesia la vida humana se despliega en sociedades como la familia, la sociedad civil o política, la iglesia, los sindicatos, la sociedad internacional, y otras manifestaciones de la agrupación humana (Código Social de Malines, 1927). De ahí que "los derechos de las personas, de la familias y de los grupos y su ejercicio deben ser reconocidos, respetados y promovidos, no menos que los deberes a los que cada ciudadano está obligado". Por ello, los ordenamientos jurídicos, los gobiernos, deben evitar "obstaculizar los deberes de los grupos familiares, sociales o culturales, los cuerpos o institutos intermedios y no los priven de su legítima y eficaz acción que por el contrario deben con voluntad y con orden favorecer" ("La iglesia en el mundo contemporáneo" -Gaudium et spes- del Concilio Vaticano II, epígrafe 75). Este pensamiento social pluralista ha tenido una gran incidencia en los movimientos sociales y políticos de

276Véase, en una perspectiva general, FEBBRAJO, A.: "E. Ehrlich: Dal diritto libero al diritto vivente", en Sociologie del diritto, núm.3 (1982), págs.137 y sigs.; FEBBRAJO, A.: "Regolazione giuridica e autoregolazione sociale", en Sociologia del diritto, núms.2-3 (1986), págs.145 y sigs.

277Cfr. PREUSS, U.K.: Revolution, Fortschritt und Verfassung, Berlin, 1990, pág.73.

278Véase HABERMAS, J.: Facticidad y validez, cit., cap.IX, págs.469 y sigs.

279Véase, en general, CAMACHO, I.: Doctrina social de la Iglesia, Madrid, San Pablo, 1998; MONEREO PÉREZ, J.L.: El catolicismo social conservador. Eduardo Sanz y Escartin, Granada, Ed. Comares, 2010.

280Véase GURVITCH, G.: La Déclaration des Droits Sociaux, New York, Editions de la Maison Française, 1944 (ed. francesa, París, Librairie Philophique J.Vrin, 1946), por ejemplo, págs.13 y 56, con referencia a MARITAIN, J.: Christianisme et Démocratie, N.Y.C., 1943.

281Véase BARBERINI, G.: L'ordinamento della Chiesa e il pluralismo dopo il Vaticano II, Perugia, Editrice Licosa, 1979, págs.3 y sigs., y 209 y sigs.

282Véase BOBBIO, N.: Voz "Pluralismo", en BOBBIO, N.y MATTEUCCI, N. (Dir.): Diccionario de política, Madrid, Siglo XXI, 1976, pág.1215. 
inspiración católica283 e incluso ha influido significativamente en la redacción del art.2 de la Constitución Italiana que garantiza los derechos inviolables del hombre ya sea como individuo ya sea en las formaciones sociales donde se desarrolla su personalidad. Esa noción refleja en sí el pluralismo social y jurídico donde se desarrolla la personalidad284. Se ha hecho notar que el concepto de persona en el Derecho contemporáneo obliga a pensar al hombre dentro de los grupos sociales de pertenencia285. Esta problemática puede vincularse sin demasiado esfuerzo con el derecho intuitivo de Gurvitch (que no se olvide que es una de las expresiones del irracionalismo jurídico)286. Para Gurvitch ni el Derecho es puramente heterónomo ni puramente autónomo287. Está integrado complejamente por reglas jurídicas abstractas y por "hechos normativos" (fuentes primarias o materiales), los cuales presentan un doble contenido inescindible, social (hecho) y normativo (jurídico), como inseparables son la misma comunidad social y el Derecho que la formaliza jurídicamente. Tales "hechos normativos" pueden ser verificados a través de dos caminos: los procedimientos técnicojurídicos (fuentes formales), propio del Derecho positivo "formal", y la contemplación directa e inmediata de la realidad fenoménica, correspondiente al Derecho positivo "intuitivo"288.

En el caso de la doctrina del "personalismo" es constatable la influencia del pensamiento de Gurvitch en Emmanuel Mounier (1905-1950), quien a diferencia de la doctrina pluralista "oficial" participa de un pluralismo conflictivo y no organicista. Su teoría personalista del poder está inspirada sin duda en la sociología de G.Guvitch y en el pluralismo democrático289. Desde su personalismo jurídico y político entiende que el Derecho es esencialmente la garantía institucional de las personas, teniendo como función principal el control sobre el ejercicio del poder, a fin de impedir la generación del abuso. Para ello propone la elaboración de un "estatuto público de la persona" acompañado de la predisposición de un sistema de límites constitucionales a los poderes públicos. Postula la creación de un orden racionalmente organizado, mediador entre espontaneidad social y

283Véase MONTERO GARCÍA, F.: El primer catolicismo social y la "rerum novarum" en España (18891902), Madrid, C.S.I.C., 1983.

284En gran medida por extensión, y por influencia de aquélla en nuestra Constitución, art.9.2 CE.

285En este sentido RIVERO, J.: Les libertés publiques, París, PUF, 1978, págs.108-109.

286Véase GURVITCH, G.: Elementos de sociología jurídica, cit., cap.II, Segunda Sección ("Sociología Jurídica Profunda"), con referencia expresa a el "derecho organizado intuitivo" y al "derecho espontáneo intuitivo".

287Véase GURVITCH, G.: L'Idée du Droit Social. Notion et Système du Droit Social, París, Sirey, 1932, pág.114.

288Véase GURVITCH, G.: L'Idée du Droit Social. Notion et Système du Droit Social, París, Sirey, 1932, págs.118 y sigs.

289 Pero también en épocas posteriores, paradigmáticamente pueden consultarse los estudios recogidos en BRUNI, L. (Coord.): Economía de Comunión. Por una Cultura económica centrada en la persona, Madrid, Ed. Ciudad Nueva, 2001, donde se apuesta, entre otras cosas, por una idea diferente de la economía basada en la experiencia de la economía de comunión en la orientación de una racionalidad económica con capacidad de comunión, capaz de superar la racionalidad instrumental e individualista (Ibid., págs. 55 y sigs., y 67 y sigs.). Véase, asimismo, MONEREO PÉREZ, J.L. y MÁRQUEZ PRIETO, A.: La idea del derecho social en la teoría general de los derechos: El pensamiento de Gurvitch, estudio preliminar a GURVITCH, G. La idea del derecho social, traducción, edición y estudio preliminar, a cargo de J.L. Monereo Pérez y A. Márquez Prieto, Granada, Ed. Comares (Col. Crítica del Derecho), 2005, págs. VIILV, y bibliografía allí citada. 
poder institucionalizados290, siendo la sociedad misma el motor de la creación jurídica autónoma y determinante en última instancia del Derecho estatal. En un sentido similar a Gurvitch, Mounier defiende la reorganización plena de la democracia política bajo el prisma de instaurar un sistema de democracia económica efectiva. Él piensa en un "Estado (Estado pluralista) articulado al servicio de una sociedad pluralista". Hay que tener en cuenta que el pensamiento de Mounier ha incidido en los procesos constitucionales llevados a cabo en la postguerra, especialmente en Francia (influencia del "estatuto público de la persona" propuesto por la revista Esprit en la Constitución francesa de 1946) y en Italia (a través del pensamiento cristiano en la elaboración de la nueva Constitución de la postguerra)291. También es en gran medida confluyente con el pensamiento de Gurvitch su planteamiento crítico sobre "el desorden establecido" como "desorden espiritual"292, donde centra su crítica a la sociedad capitalista ante todo desde el punto de vista espiritual y moral y no sólo en el plano político y económico. Para él, como para Gurvitch, la transformación de las estructuras debe estar acompañada de una transformación espiritual. Pero es que, además, los puntos de proximidad son todavía mayores cuando se comprueba que la idea del personalismo entronca con la tradición proudhoniana y anarquista del socialismo francés (cfr. su obra Anarquismo y personalismo). Gurvitch también es -y así se consideraba expresamente293- heredero de esa tradición proudhoniana. De ahí que Mounier -como el propio Gurvitch- postule la necesidad de una autoorganización de la sociedad, la cual permitirá a la persona formarse plenamente a través de la cultura, la educación y la pertenencia a comunidades y asociaciones que la vertebran socialmente (familia, Iglesia, Sindicato, movimientos sociales diversos, etcétera)294. Sin embargo, tanto Mounier como

290Gurvitch entrevió la amenaza de la supeorganización de la sociedad contemporánea, la cual puede suponer que la organización política de la sociedad ciege sus propias fuentes vivificantes. Trás ello late el riesgo de disolución y dispersión de la espontaneidad social, por lo que la sociedad quedaría desintegrada de valores aglutinantes de los individuos. Cfr. GURVITCH, G.: "Hyper-empirisme dialectique. Ses aplications en sociologie", Cahiers Internationaux de sociologie, XV, PUF, 1953, págs.3 a 33.

291Véase MOUNIER, E.: Revolución personalista y comunitaria (1935), Madrid, Ed.Zero, 1975; Id.: De la propiedad capitalista a la propiedad humana (1936), Buenos Aires, Lohlé, 1984; MOUNIER, E.: Manifiesto al servicio del personalismo (1936), Madrid, Taurus, 1976; MOUNIER, E.: El personalismo (1949), Buenos Aires, Eudeba, 1984. Sobre el pensamiento de Mounier, véase MOIX, C.: El pensamiento de Enmanuel Mounier (1960), Madrid, Editorial Estela, 1964; RIGOBELLO, A.: Il contributo filosofico di Enmanuel Mounier, Milán, Bocca, 1955; GUISSARD, L.: Enmanuel Mounier, Barcelona, Editorial Fontanella, 1965; LACROIX, J.: Marxismo, existencialismo, personalismo (1950), Barcelona, Ed. Fontanella, 1965; GOGUEL, F.y DOMENACH, J.M.: Pensamiento político de Mounier, Madrid, Ed. Zero, 1970.

292Véase MOUNIER, E.: Revolución personalista y comunitaria, Madrid, Ed. Zero, 1975, págs.281 y sigs. ("Ruptura entre el orden cristiano y el desorden establecido").

293Véase su obra última, GURVITCH, G.: Proudhon. Su vida, su obra, su filosofía, trad. J.Marfá, Madrid, Eds.Guadarrama, 1974.

294En general Gurvitch creía en la existencia de unidades sociales colectivas con un ordenamiento propio independiente del ordenamiento estatal. Podría trazarse -manteniendo las oportunas distancias- una cierta proximidad con la teoría de la Genossenschaft de Otto von Gierke. Puede verse GIERKE, O. Von.: La función social del Derecho privado (1899). La naturaleza de las asociaciones humanas (1902), trad. directa del alemán de J.Ma . Navarro Palencia, Madrid, Sociedad Editorial Española, 1904; MONEREO PÉREZ, J.L.: La teoría jurídica y social de Otto von Gierke: Teoría del Derecho Social y de las personas colectivas, estudio preliminar a GIERKE, O. VON: La función social del Derecho privado y otros estudios, Trad. José M. Navarro de Palencia, revisión y edición a cargo de J.L. Monereo Pérez, Granada, ed. Comares (Col. Crítica del Derecho), págs. IX-LXI, 2015. Para Gierke la sociedad ordenada jurídicamente es un todo, en el cual reside una unidad real, debiéndose reflejar la realidad en el Derecho (Ibid. 72-73). Para él la teoría orgánica considera 
Gurvitch no defienden la desaparición del Estado, éste debe asumir su función de garante de los derechos de la persona y debe tener una posición también activa respecto al mantenimiento del pluralismo existente en las instituciones sociales. En caso de conflictos debe asumir una función mediadora y arbitrar que se asegure una organización racional de la sociedad democrática.

\section{LA IDEA DEL DERECHO SOCIAL: EL SISTEMA DE DERECHO SOCIAL}

En el pensamiento de Gurvitch el Derecho social es el Derecho autónomo de "comunión" por el cual se integra de una forma objetiva cada totalidad activa, concreta y real encarnando un valor positivo, Derecho de integración (o si se prefiere de inordinación), distinto del derecho de coordinación (orden de Derecho individual) y del Derecho de subordinación, solo reconocido por los sistemas del individualismo jurídico y del universalismo unilateral295. Frente al individualismo jurídico que informa el Derecho individual, el

como organismos sociales al Estado y demás asociaciones; por consiguiente, coloca la existencia del organismo total, del cual el hombre constituye una parte, por encima del organismo individual. (Ibid. 73). Teoría organicista que se hace confluir con la doctrina de la Iglesia católica (Ibid. 75). Por eso entiende que siempre que aparezca la persona colectiva, la ciencia del Derecho tiene por misión el abarcar, ordenar y desarrollar la vida interna y externa de las colectividades, mediante principios jurídicos adecuados, como expresión de la unidad de vida moral y material de los organismos sociales (Ibid. 85). Según Gierke, el Derecho social es una ordenación de vida para los seres vivos sociales, de manera que la parte del Derecho social que regula la vida interna de las sociedades debe ser, por consiguiente, fundamentalmente distinta de todo Derecho que regule las relaciones externas de los seres vivos reconocidos como sujetos. El Derecho debe estar en armonía con la doble naturaleza del hombre, al mismo tiempo que un todo sustantivo, es parte de un todo más elevado; debe dividirse en dos grandes ramas, a las cuales podemos calificar: una, de Derecho individual; otra, de Derecho social. En el Derecho social hay que incluir el Derecho público, así como también la organización interior de la vida de las personas sociales privadas, incorporada al Derecho privado: en el Derecho social deben prevaler conceptos que ningún modelo tienen en el derecho individual; pues lo que con respecto a la persona individual está sustraído a una ordenación jurídica, puede aquí ser sometido a organización jurídica mediante dichas reglas. (Ibid. pág. 86).

En esto -escribe- puede el Derecho determinar legalmente la construcción del todo viviente en sus partes, y la actividad de su unidad en la pluralidad de dichas partes, por qué y en tanto que la vida interna del organismo social es justamente vida externa de hombres o de menores asociaciones humanas. El concepto de Derecho sale a la superficie con la constitución. Es característica del Derecho social el que pueda transformar en relaciones jurídicas las relaciones entre un todo unitario y sus partes. Considera que después de todo esto parece confirmada la concepción orgánica de las asociaciones en la ciencia del Derecho. Esta tiene que ocuparse de las unidades sociales vivas, sólo en tanto que producen efectos en el Derecho, y, por consiguiente, debe proceder necesariamente de un modo unilateral; la vida jurídica es solamente un aspecto, y en manera alguna el más importante de la vida social: su ciencia debe tener conciencia de esta parcialidad. De modo que también en esto se debe tener presente, constantemente, que las fuerzas vivas de los organismos sociales se manifestan más allá del derecho en todos los movimientos de cultura y de poder, y que sus resultados más potentes se realizan independientemente del Derecho, cuando no contra él. (Ibid., págs. 86-93). El propio Gurvitch dedica una atención especial a Otto von Gierke, GURVITCH, G.: La idea del Derecho Social, traducción y estudio preliminar a cargo de J.L. Monereo Pérez y A. Márquez Prieto, 2005, capítulo Quinto ("La teoría del Derecho social y las "personas colectivas complejas" de Otto Von Gierke"), págs. 591 y sigs., y antes, GURVITCH, G.:”Otto von Gierke als Rechtsphilosoph”, Logos, XI, 1922-1923, págs. 86-132; GURVITCH, G.: Otto von Gierke als Rechstsphilosoph, Tübingen, J.C.B. Mohr, 1922.

295GURVITCH, G.: L'Idée du Droit Social. Notion et Système du Droit Social, París, Sirey, 1932 (reimpresión alemana de la edición de París de 1932, Scientia Verlag Aalen-1972), págs.11-12. El autor propone una noción de Derecho social que recogería descriptivamente todos los elementos caracterizadores del mismo: el Derecho social -escribe- es un derecho autónomo de comunión, integrando de una forma objetiva 
Derecho social de integración se construye sobre el principio de solidaridad social. A la concepción individualista del Derecho se opone el Derecho social basado en la imagen del hombre sujeto a vínculos sociales, del hombre "específico", socialmente situado (es decir, en la especificidad de sus diferentes posiciones en la estructura social), frente a la contemplación individualista del hombre abstracto o genérico296.

Una de las premisas sistemáticas de la noción técnica de Derecho social es para Gurvitch la noción de "hecho normativo". Este concepto enlaza directamente con la teoría de las fuentes del Derecho positivo, en el sentido de que los "hechos normativos" son las fuentes primarias, diferenciadas de las fuentes secundarias o formales297. Gurvitch propone una configuración original de la noción "Derecho social", que sirve de base en gran medida a todo su sistema pluralista y a la elaboración de su importante "Proyecto de declaración de derechos sociales". En una delimitación negativa, el término "derecho social" no debe vincularse unidireccionalmente a la "política social del Estado". Ciertamente se ha utilizado respecto a la legislación del Estado en respuesta a la "cuestión social"298, pero en opinión de Gurvitch esta interpretación del "Derecho social" es errónea, desde el punto de vista teórico, y peligrosa para la democracia, desde el punto de vista práctico.

Entiende que esa concepción restrictiva del Derecho social es sustancialmente errónea e incompleta, porque desatiende el fenómeno primordial en la experiencia jurídica del pluralismo jurídico en la vida real del Derecho, que es una consecuencia del pluralismo de hecho en la realidad social. Cada grupo y cada conjunto posee, en efecto, la capacidad de engendrar su propio orden jurídico autonómico reglamentando su vida interior. Los grupos

cada totalidad activa real, que encarna una valor positivo extra-temporal. Este derecho se separa directamente del "todo" en cuestión para reglar la vida interior, independientemente del hecho de que ese "todo" esté organizado o inorganizado. El derecho de comunión hace participar el todo de una forma inmediata en la relación jurídica que de él deriva, sin transformar ese "todo" en un sujeto separado de sus miembros. El "derecho de integración" instituye un "poder social" que no está esencialmente vinculado a una sujeción incondicionada y que puede plenamente realizarse en la mayoría de los casos por una sujeción relativa de la cual no se puede substraer. Bajo ciertas condiciones este poder social funciona perfectamente incluso sin sujeción. El Derecho social precede, en su inclinación primaria, a toda organización del grupo y no puede expresarse de una forma organizada más que cuando la asociación está fundada sobre el Derecho de la comunidad subyacente objetiva y por ella penetrada, es decir, cuando ella constituye una asociación igualitaria de colaboración y no una asociación jerárquica de dominación. El Derecho social se dirige, en su vocación organizadora, a sujetos jurídicos específicios -personas colectivas complejas- tan diferentes de los sujetos individuales aislados como de las personas morales -unidades simples- que absorben la multiplicidad de sus miembros en la voluntad única de la corporación o del establecimiento (Ibid., págs.15-16).

296Véase, al respecto, MONEREO PÉREZ, J.L.: La Filosofía de Gustav Radbruch: Una lectura jurídica y política, estudio preliminar a RADBRUCH, G.: Filosofía del Derecho, edición de J.L. Monereo Pérez, Granada, Ed. Comares, (Col. Crítica del Derecho), 1999, págs.XCIV ("Justicia y Derecho social en Radbruch: del Derecho individual al Derecho social general"); MONEREO PÉREZ, J.L.: El Derecho en la democracia constitucional. La teoría de Gustav Radbruch, Barcelona, Ediciones de Intervención Cultural/El Viejo Topo, 2020.

297Véase ampliamente GURVITCH, G.: L'Idée du Droit Social, cit., cap.IV (Premisas sistemáticas de la noción de Derecho social), págs.95 y sigs., donde, por otra parte, y significativamente, se aprecia la influencia determinante de la filosofía de Fichte.

298En tal sentido se comprende bajo el término "Derecho social" el conjunto de reglas jurídicas, y particularmente las leyes del Estado, que protegen los elementos débiles y no-poseedores de la Sociedad y ordenan la intervención del Estado en la esfera económica. Cfr. GURVITCH, G.: La Déclaration des Droits Sociaux, cit.,pág.72. 
y sus conjuntos no atendienden a la intervención del Estado para participar, en tanto que fuerzas autónomas de reglamentación jurídica, a la trama compleja de la vida del Derecho, donde los diferentes órdenes de Derecho se confrontan, se combaten, se interpenetran, se equilibran y se situán jerárquicamente de la forma más variada299. Y es que, hace notar Gurvitch, la implicación ideológica de la interpretación errónea del Derecho social es la teoría estatalista y monista del Derecho300, cuya fundamentación no puede resistir ningún análisis crítico serio, ni sociológico, ni jurídico, ni filosófico. Todo Derecho no es más que un ensayo de realizar un de los múltiples aspectos de la Justicia en las esferas sociales más diversas y variadas, a condición de que sea capaz de garantizar para su existencia y su actividad un mínimo de validez de las reglas así engendradas. He aquí que toda sujeción organizada y todo poder para ser legítimo, no puede apoyarse más que sobre un Derecho preexistente en el medio social, Derecho que les organiza. En la sociedad pluralista, el Derecho estatal no es más que una isla, más o menos extensa, en un vasto oceano de órdenes de Derecho de diferentes géneros o especies, tanto superiores (Derecho espontáneo de la Nación y Derecho internacional), como equivalentes (Derecho de la Organización Nacional Económica, etcétera...), como sometidos en su validez jurídica al Derecho del Estado. Agrega Gurvitch que el Derecho social debe ser interpretado (y lo hace así en su "Proyecto de Declaración de Derechos") de una forma distinta, excluyendo todo prejuicio estatista y toda tentación totalitaria301.

Según Gurvitch, el Derecho social es un Derecho de integración, opuesto al derecho de subordinación o de dominación. Es engendrado por cada fusión parcial, por cada interpenetración en el "nosotros" que es la base normal de la vida de todo grupo. Precisamente el Derecho social hace participar directamente a los sujetos que agrupa en la elaboración de reglas jurídicas302. Es, por ello, consustancialmente democrático y contribuye a realizar el principio de la democracia constitucional. Esta forma de Derecho está fundada en la confianza y la participación, el Derecho social no puede nunca ser impuesto y favorece la autonomía jurídica de los interesados y les permite gobernarse a sí mismos. Entiende que se puede decir de una forma general que toda estructura democrática, desde el punto de vista jurídico, es Derecho Social Organizado, es decir, una forma de ordenación de toda organización (sea económica, política u otra) gracias a la cual cualquier garantía es dada, más podría ser enteramente determinada y penetrada por el Derecho social de la comunidad subyacente a esta organización. En este sentido el Estado democrático y su orden jurídico son ellos mismos la manifestación de una especie particular de Derecho social, que emana de la comunidad política subyacente de ciudadanos (Derecho social del conjunto de los agrupamientos de localidad, acompañado de una sujeción incondicionada).

299Véase, ampliamente, GURVITCH, G.: L'Idée du Droit Social. Notion et Système du Droit Social, París, Sirey, 1932.

300Es una reacción análoga a la postura de Ehrlich en cuanto al rechazo de las concepciones estatalistas del Derecho y a la misma idea de absorción por el Estado del monopolio de la producción jurídica. Véase EHRLICH, E.: Ifondamenti della sociologia del diritto, Milano, Giufrè, 1976, págs.174 y sigs. (la estatalización del Derecho), y págs.193 y sigs. (la concepción estatalista del Derecho).

301GURVITCH, G.: La Déclaration des Droits Sociaux, cit., págs.73 y 75.

302GURVITCH, G.: La Déclaration des Droits Sociaux, cit., pág.75. 
Sin embargo, Gurvitch trató en su propuesta de "Declaración de Derechos Sociales" sólo las especies extra-estatales de Derecho social emanado de las comunidades de productores, de consumidores, y de sus organizaciones, así como de los derechos que constituyen las prerrogativas del hombre. Las declaraciones de derechos sociales deben reconocer estos derechos sociales subjetivos de grupos, de colectividades o conjuntos sociales y de individuos.

Es así que el Derecho Social es un Derecho de integración, por lo que los derechos sociales proclamados por las Declaraciones constitucionales deben ser los derechos de participación de los grupos y de los individuos derivados de su integración en colectividades y garantizando el carácter democrático de estas últimas. De manera que completar la Declaración de los Derechos Políticos con una Declaración de Derechos Sociales, es proclamar los derechos de productores, de consumidores y del hombre (hombre específico), en tanto que individuos y en tanto que grupos, a una participación efectiva en todos los aspectos de la vida, del trabajo, de la seguridad, del bienestar, de la educación, de la creación cultural; así como todas las transformaciones posibles de la autonomía jurídica, de control democrático por los interesados, del autogobierno y de la acción judicial. Considera que proclamar el derecho de individuos, de grupos -conjuntamente pues no debe existir sustituibilidad entre ellos- a una organización pluralista de la sociedad, es lo que permitirá garantizar la libertad humana en las condiciones actuales303. Es significativo que el texto del "Proyecto de Declaración de los Derechos Sociales" comience indicando que el objetivo de la Sociedad es la fraternidad de los hombres y de los grupos, realizándose por la variedad en la unidad, es decir, por una pluralidad de asociaciones u organizaciones de colaboración igualitarias, integradas en la comunidad nacional y protegiendo la libertad y la dignidad humana de cada partícipe304.

Esta visión pluralista de la sociedad determina también una visión compleja e integradora de la noción de interés general, pudiéndose hablar de "pluralidad de aspectos del Interés General"305, de manera que no suponga atribuir el monopolio de la representación del interés general al Estado. En ese sentido entiende que el interés general no es más que un equilibrio móvil entre los intereses contrarios y que existen tanto aspectos múltiples y equivalentes de interés general, como posibilidades de equilibrar los intereses contrarios. Es ésta una concepción del interés general como un "balanceamiento", un equilibrio de intereses antinómicos, lo cual hace necesario que haya una pluralidad de aspectos equivalentes del interes general y que cada uno de estos aspectos pueda ser representado por comunidades funcionales y organizaciones superpuestas de carácter muy diverso, lo cual es en sí positivo desde un punto de vista esencialmente pluralista306.

303En este sentido GURVITCH, G.: La Déclaration des Droits Sociaux, cit., págs. 79-80.

304GURVITCH, G.: La Déclaration des Droits Sociaux, cit., pág.85.

305GURVITCH, G.: La Déclaration des Droits Sociaux, cit., pág.120. Esta idea se vincula en gran medida al pensamiento de Maurice Hauriou, como puede comprabarse ya en GURVITCH, G.: L'Idée du Droit Social, cit., pág. 708.

306GURVITCH, G.: La Déclaration des Droits Sociaux, cit., págs.123-124. 


\section{DERECHO SOCIAL Y SOCIEDAD DEMOCRÁTICA: EL DERECHO SOCIAL EN LA CONSTITUCIÓN DEL TRABAJO Y DE LA DEMOCRACIA PARTICIPATIVA}

\section{En general}

Gurvitch defendió una democracia cualitativa frente a la democracia meramente cuantitativa, que para él es la democracia liberal, la cual priva a los individuos y a los grupos sociales de sus facultades de autodeterminación social y jurídica. Para Gurvitch, el individualismo unilateral no satisface las exigencias de una democracia cualitativa basada en la participación directa de los individuos y grupos sociales en la construccion del modelo de sociedad. Entiende que la democracia formal debe de ser completada -no sustituida- con la democracia social y política en todos los ámbitos de la vida social: se trata -la propuesta por él- de una democracia poliédrica que combina dos dimensiones o aspectos de la democracia: política y socio-económica. Esta última se alcanzaría a través de una reforma institucional profunda que garantizase la participación activa a través de los "Consejos Nacionales de Economía" y las instituciones de la democracia industrial307. No debería personificarse exclusivamente en el Estado, sino que también desplegaría toda su fuerza en las distintas organizaciones de la sociedad civil y en una serie de instituciones de participación en la dirección de la economía, siendo así que el Estado no es ni el intérprete supremo ni el único del interés general. De ahí su dura crítica a Hegel a quien reprocha el haber establecido los fundamentos políticos y jurídicos del Estado autoritario y haber separado la sociedad política de la sociedad civil, creando una fractura insalvable que impide la intervención activa de todos los individuos y grupos sociales en la construcción de la sociedad democrática308.

En tal sentido entiende que es necesaria una nueva "revolución" en las declaraciones de derechos como instrumentos constituyentes de la nueva sociedad democrática por él propugnada, las cuales deberán realizar los valores superiores de la libertad, la igualdad y la fraternidad en el dominio o ámbito económico. Piensa que se debería socializar sin estatalizar309: desde la ordenación de la economía general hasta la actividad empresarial,

307Para la crítica a la visión clásica de la democracia liberal, véase GURVITCH, G.: "Le principe démocratique et la démocratie future", en Revue de métaphysique et de morale, 1929, págs.405 y sigs. Sobre esta problemática de la posición de los iussocialistas pluralistas, MONEREO PÉREZ,J.L.: La filosofía política de Harold J. Laski, estudio preliminar a LASKI, H.J.: La Gramática de la política. El Estado Moderno, trad. T. González García, revisión, edición y estudio preliminar a cargo de J.L. Monereo Pérez, Granada, Ed. Comares (Col. Crítica del Derecho), 2002, págs. XV-C.; MONEREO PÉREZ, J.L.: La democracia en crisis: Harold J.Laski, Barcelona, Ediciones de Intervención Cultural/El Viejo Topo, 2004; MONEREO PÉREZ, J. L.: "Democracia social y económica en la metamorfosis del Estado moderno: Harold J. Laski.Lex Social: $\quad$ Revista De Derechos Sociales, 11(1), 298-377 (2021). https://doi.org/10.46661/lexsocial.5426.

308Véase GURVITCH, G.: L'Idée du Droit Social, cit., págs.330 y sigs.

309Salvando las distancias evidentes entre ambos (Korsch se inscribía en la tradición cultural del socialismo marxista; Gurvitch, en la tradición del socialismo democrático de inspiración autogestionaria, y muy influido, como quedó dicho, por el pensamiento de Proudhon), es necesario subrayar la proximidad de puntos de vista entre Gurvitch y Karl Korsch, el cual defendió un programa de socialización no estatalista, socialista y sindicalista, a través de mecanismos de autoorganziación directa de la sociedad y de los grupos sociales, 
con el reconocimiento del derecho del trabajador a la participación en la dirección del proceso de producción en correspondencia con la importancia del trabajo en el seno de la organización productiva. Nótese, por otra parte, que en el pensamiento de Gurvitch está inscrita fuertemente la idea de que en toda sociedad (incluida la democracia avanzada y socialista autogestionaria) van a existir siempre tensiones entre intereses sociales contrapuestos. Hasta tal punto es así que se puede decir que la persistencia del conflicto social se constituye en sí en factor constitutivo de toda sociedad realmente democrática 310.

Importa señalar que Gurvitch sitúa el proceso de reformismo social en una perspectiva inequívocamente constitucional: el desarrollo del constitucionalismo estatal, económico e industrial. En este sentido debería proclamarse una Declaración de Derechos sociales que garantizase posiciones activas de ventaja de los individuos y grupos de pertenencia en todos los ámbitos de la vida social311. Esa Declaración de Derecho suponía el intento de introducir reformas constitucionales encaminadas a hacer realizar los principios de una

especialmente en el ámbito de la dirección de las empresas socializadas. Véase esa proximidad respecto al paradigma de socialización económica y jurídico-institucional, en KORSCH, K.: ¿Qué es la socialización?, Barcelona, Ariel, 1975, págs.21 y sigs., y 73 y sigs., y 80 y sigs.; KORSCH, K.: Lucha de clases y Derecho del Trabajo (1922), Barcelona, Ariel, 1980. Para el pensamiento de Korsch sobre la constitución jurídica de la economía socializada de transición hacia el socialismo, véase las aportaciones contenidas en la obra colectiva, AA.VV.: Karl Korsch o el nacimiento de una nueva época, Barcelona, Ed.Anagrama, 1973, y, en una perspectiva de conjunto sobre el reformismo iusocialista, MONEREO PÉREZ, J.L.: Fundamentos doctrinales del Derecho social en España, Madrid, Ed. Trotta, 1999.

310Esta idea de persistencia del conflicto social que no desaparecía con la socialización es un nuevo puente de unión entre el esquema de pensamiento de Gurvitch y el modo de pensar de Karl Korsch. Cfr.KORSCH, K.: ¿Qué es la socialización?, Barcelona, Ariel, 1975, passim. Esa contraposición de intereses sociales no tiene por qué residenciarse en el ámbito de la producción, ya que puede producirse entre los consumidores y los productores, y entre éstos y una burocracia dominante que realiza una actividad de planificación o programación de la economía general y de la producción (véase, Ibid., págs.36-37). Korsch indica que de acuerdo con el auténtico espíritu socialista, sin embargo, el objetivo de la socialización no es el capitalismo de consumidores ni el de productores, sino la implantación de una verdadera propiedad comunitaria para el conjunto de productores y consumidores (Ibid., págs. 37 y 43). Con lo que la proximidad de puntos de vista es todavía más evidente entre ambos autores. Para la concepción de la democracia económica en una constitución del trabajo en los iussocialistas pluralistas, véase MONEREO PÉREZ, J.L.: La democracia en crisis: Harold J.Laski, Barcelona, Ediciones de Intervención Cultural/El Viejo Topo, 2004; MONEREO PÉREZ, J. L.: "Democracia social y económica en la metamorfosis del Estado moderno: Harold J. Laski. Lex Social: Revista De Derechos Sociales, 11(1), 298-377 (2021).

https://doi.org/10.46661/lexsocial.5426. Es clásica la configuración de la constitución del trabajo en la de Karl Korsch en el marco de la Constitución de la República de Weimar (1919), KORSCH, K.: Luchas de clases y Derecho del Trabajo (1922), Barcelona, Ed. Ariel, 1980, passim; KORSCH, K.: ¿Qué es socialización?, Introducción de E. Gerlach, trad. J. Muñoz. Barcelona, Ed. Ariel, 1975.

311Véase GURVITCH, G.: La Déclaration des Droits Sociaux, New York, Editions de la Maison Française, 1944 (ed. francesa, París, Librairie Philophique J.Vrin, 1946), pág.11. Esta obra pretendía introducir en el debate de la Asamblea constituyente de la Francia de la postguerra la oportunidad político-jurídica de establecer una Declaración de Derechos Sociales. Lo indica expresamente su autobiografía intelectual cuando indica que partiendo de la distinción neta entre "los juicios de valor y los juicios de realidad", se estructura "en forma de programa consciente de acción políticosocial en mi Declaración de los Derechos Sociales, escrita en Nueva York en 1944, con el fin de inspirar la constitución de la IV República, desgraciadamente en vano... Sin embargo, un comienzo de realización de ese programa puede observarse en la República Federalista Popular Yugoslava, durante los últimos años". Cfr. "Mon itinéraire intellectuel ou l' exclu de la horde", en Lettres Nouvelles, núm.6 (1958), págs.65 a 83. Publicado después en L' Homme et la Société, I, 1966; y en la recopilación de DELEDALLE, G. y HUISMAN, D.: Les philosophes français d' aujourd' hui pas euxmêmes. Autobiografhie de la philosophie française contemporaine, París, C.D.U., 1963, págs.100 a 116; igualmente recogido en DUVIGNAUD, J.: Georges Gurvitch, París, Éditions Seghers, 1969, págs.79 a 98. 
democracia participada y del pluralismo jurídico. Su defensa de la libertad y de la participación era ejemplar en el tiempo histórico en que fue formulada312. Con ello Gurvitch se introduce en el debate social y político de su tiempo, al establecer en esta obra todo un programa consciente de acción política y social, en el marco de una situación de transición del sistema de Derecho de la sociedad actual313. En esta obra Georges Gurvitch aparece en su doble dimensión de pensador político-jurídico y de sociólogo. Piensa que la comprensión liberal de la democracia es una falsificación mutilante del principio democrático. En sus obras tratará de establecer los principios y las reformas estructurales necesarias para realizar el auténtico "espíritu democrático"314.

Los derechos sociales deben ser ante todo una emanación de los grupos sociales autónomos y de los individuos en tanto que centros activos de la vida jurídica. Tales derechos no deben de estar concebidos más que como "deberes" del Estado y de los programas de legislación, porque de ser así ello podría fácilmente conducir a nuevas servidumbres. Entraña, en efecto, el riesgo de que se transite desde el "Estado-servidor" al "Estado-Déspota"315. Por ello intentará establecer una sociedad civil fuerte y colectivamente articulada, para evitar su dependencia de variaciones contigentes en el régimen político. De lo que se trataría es de establecer una verdadera declaración de derechos y no sólo de programas y de promesas de legislación social del Estado316. Él subraya que debería implantarse una declaración de derechos sociales fundada en un sentido agudo de limitaciones del poder, de la autonomía de los grupos, de socialización sin estatización, de las técnicas pluralistas aprovechando la multiplicidad de grupos que se gobiernan ellos mismos y de antinomias sociales, para reforzar por su equilibrio la libertad bajo todas sus formas317. Esta concepción de Gurvitch se muestra de gran actualidad cuando hoy se fomenta la sociedad civil no como alternativa a la intervención del Estado sino como garantía de libertad y de participación de los ciudadanos en la vida democrática.

312Por eso parece excesivamente dura la crítica de Bobbio realizada contra un pensador tan imaginativo e influyente en la práctica político-jurídica de su tiempo como Georges Gurvith. En efecto, Bobbio, sin introducir una argumentación mínimente sólida al respecto, afirma que dicha obra "puede parecer hoy, con la reforma ya producida, anacrónica. Pero sería un error entender que no fuese un poco anacrónica también cuando fue escrita. Y sería igualmente ingenuo creer que el autor no lo supiese. ¿Debemos por eso pensar que haya perdido todo valor? Caído el proyecto, sobreviven las ideas que están destinadas a permanecer todavía en la circulación del pensamiento político de nuestros tiempos, por lo menos hasta que el Leviatán, devorador de hombres, no sea domado. Pero, ¿quien osaría decir hoy que la crisis del Estado moderno haya llegado a su fin?". Cfr. BOBBIO, N.: "Gurvitch y los derechos sociales", en BOBBIO, N.: El tiempo de los derechos, Madrid, Ed.Sistema, 1991, págs. 27 y sigs., en particular pág.35.

313Antes de la elaboración de su Declaración de Derechos de 1944, hacía referencia a ese "sistema transitorio" que caracteriza al Derecho de la sociedad de su tiempo. Véase GURVITCH, G.: Elementos de sociología jurídica, cit., Introducción, págs.227 y sigs.

314Para la propuesta de una democracia cualitativa opuesta a la democracia cuantitativa de la tradición liberal, véase el ensayo MIQUEL, J.: "Georges Gurvitch: Democratie quantitative et democratie qualitative", en Procès. Cahiers d'analyse politique et juridique, monográfico sobre "Droit et agrégation sociale", núm.8 (1981), págs.91 y sigs.

315En este sentido sustancial, véase GURVITCH, G.: La Déclaration des Droits Sociaux, cit., pág.24.

316In fine, GURVITCH, G.: La Déclaration des Droits Sociaux, cit. pág.36.

317Véase GURVITCH, G.: La Déclaration des Droits Sociaux, cit., págs.45-46. 
Esta nueva declaración complementaria e integradora de la "clásica" se basa en la idea social, no contrapuesta a la idea individual318. Dicha declaración podría hacer frente a los nuevos obstáculos planteados a la democracia por el desarrollo del capitalismo moderno. Estos obstáculos son infinitamente más amenazantes para los valores democráticos. El paso del capitalismo fundado sobre la libre concurrencia al capitalismo organizado, ha conducido a la dominación, en la vida económica, e incluso en la vida política, de las grandes sociedades accionarias, de trusts, de cartels, de sociedades privadas de seguros, de instituciones bancarias. Este "gobierno privado" interviene continuamente en el funcionamiento normal de la democracia política. Esta situación puede fácilmente agravarse hasta la desintegración de la unidad de la Nación, esta comunidad global que ha servido de base primaria a la democracia319. También el incremento del "poder autocrático" de los empresarios sobre los trabajadores de las empresas, apoyado en la enorme concentración de la riqueza, la propiedad de los medios de producción y en el desarrollo tecnológico; los instrumentos nuevos de dominación ligados a la posesión y a la capacidad misma de mandar y de dirigir los poderosos medios técnicos modernos. Cuando el "feudalismo económico" que sujeta al Estado se combina con el régimen tecnocrático queda abierto el camino hacia el totalitarismo político y social 320 .

Para Gurvitch el pluralismo puede y debe ser observado desde tres puntos de vista: el pluralismo como hecho, como ideal y como técnica321. El principio del pluralismo comporta una multiplicidad de sentidos. Así, desde la perspectiva sociológica el pluralismo es un hecho que puede ser observado en toda sociedad a través de la existencia de un microcosmos de agrupamientos particulares que se superponen dialécticamente. Por su parte, el pluralismo como un ideal se refleja en una armonía entre la variedad y la unidad, siendo así que el ideal democrático tiene su fuente primaria en el ideal pluralista. Por ello considera que el principio democrático es, bajo todos los aspectos, inseparable del ideal pluralista integrador y no destructivo322. Finalmente, el sentido del pluralismo como técnica remite a su concepción como método específico utilizado en la lucha por la realización de la libertad humana y de los valores democráticos. En este sentido el pluralismo contemporáneo se aparta de la técnica monista y estatista que había imperado desde el triunfo de las revoluciones liberales burguesas, y que encontró su fundamento en la necesidad de limitar el pluralismo degenerado que trataba de perpetuar la servidumbre, aunque a veces ello supuso incurrir en la negación de la cultura jurídica comunitaria solidaria no siempre servil. Sin embargo, Gurvitch plantea que esa posición que encontró la mencionada justificación hoy día no es proponible, ya que el período histórico de la postguerra había revelado los

318Véase GURVITCH, G.: L'Idée du Droit Social. Notion et Système du Droit Social, París, Sirey, 1932.

319GURVITCH, G.: La Déclaration des Droits Sociaux, cit., pág.49.

320GURVITCH, G.: La Déclaration des Droits Sociaux, cit., pág.52.

321 Véase ampliamente GURVITCH, G.: La Déclaration des Droits Sociaux, cit., págs. 58 y sigs.

322GURVITCH, G.: La Déclaration des Droits Sociaux, cit., pág.61. Su concepción del pluralismo iussocial se percibe perfectamente ya desde el art. $1^{\circ}$ de su Proyecto de Declaración de Derechos Sociales -y se refleja en todo el texto de la misma-, a cuyo tenor "El fin de la Sociedad es la fraternidad de los hombres y de los grupos, se realiza por la variedad en la unidad, es decir, por una pluralidad de asociaciones de colaboración igualitaria, integradas en la comunidad nacional y protegiendo la libertad y la dignidad humana de cada partícipe" (Ibid., pág.85). 
temibles efectos del "Estado Leviatán" que tendía a absorber la sociedad civil o limitar, desnaturalizándolas, sus distintas formas de expresión. Por ello considera necesario adaptar una técnica pluralista más coherente con la libertad humana en sus distintos modos de manifestación. Para él esa técnica pluralista nueva serviría para limitar la esfera de actuación del Estado por una "Organización económica" independiente del gobierno, y recíprocamente, para instaurar "contrapoderes" efectivos en la Constitución Política y la Constitución social, entre la Democracia Política y la Democracia Económica, entre la propiedad pública y la propiedad social, entre el Interés General Político y el Interés General Económico, entre los Productores y los Consumidores, entre los dos últimos tomados conjuntamente y los Ciudadanos. Precisamente -escribe- de esta técnica pluralista rigurosa debe venir la inspiración principal de una Nueva Declaración de Derechos en el marco del proceso de reforma constitucional323, con la cual pretendía incidir en la dinámica del movimiento histórico.

Postula -una vez explicada la realidad social- una suerte de socialización institucionalizada a través de la limitación del Parlamento político del Estado por un Consejo Nacional Económico, dirigiendo la economía planificada autónoma y basado sobre una propiedad social, que haría de contrapoder a la propiedad estatal en un proceso de socialización de la economía324. Se trataría del establecimiento de contrapoderes eficaces fuera y no en el interior del Estado como organización específica del poder político institucionalizado325. Su propuesta acaba reflejándose en un programa de constitucionalización jurídica de la democracia económica. En ese proceso de democratización propuso establecer un conjunto de instituciones nuevas: Consejos de Control, Consejos de Gestión y Consejo Nacional de Economía. Los "Consejos de fábrica y de empresa" sirven de base a la "fábrica constitucional". Pero los "consejos de fábrica" experimentados entre las dos guerras son instrumentos débiles ya que no estaban integrados -como propone Gurvitch- en un conjunto de órganos de democracia industrial. La democracia industrial debe estar inserta en un sistema institucional de democracia económica, donde la centralidad la tendría el Consejo Nacional Económico y el Consejo Económico Internacional326. Llega a proponer -no sin manifiesta ingenuidad por la dificultad técnica, y no sólo política de que pudiera realizarseque la "Organización Internacional del Trabajo", que ha mostrado su efectividad, sea transformada en un Consejo Internacional Económico, fuertemente asentado sobre los Consejos Nacionales Económicos y sobre la representación directa de los productores y de

323GURVITCH, G.: La Déclaration des Droits Sociaux, cit., págs.62-63.

324Véase nuevamente la proximidad en este modo de pensar con KORSCH, K.: ¿Qué es la socialización?, Barcelona, Ariel, 1975, passim.

325GURVITCH, G.: La Déclaration des Droits Sociaux, cit., págs.64-65. Sobre toda esta problemática, véase MONEREO PÉREZ, J.L.: "Derechos sociales y Estado democrático social en Antón Menger", estudio preliminar a MENGER, A.: El derecho al producto íntegro del trabajo. El Estado Democrático del Trabajo (El Estado Socialista), edición de J.L. Monereo Pérez, Granada, Ed. Comares (Col. Crítica del Derecho), 2004, págs. XI-LXXVIII; MONEREO PÉREZ, J.L.: La democracia en crisis: Harold J.Laski, Barcelona, Ediciones de Intervención Cultural/El Viejo Topo, 2004; MONEREO PÉREZ, J. L.: "Democracia social y económica en la metamorfosis del Estado moderno: Harold J. Laski", en Lex Social: Revista De Derechos Sociales, 11(1), 298-377 (2021). https://doi.org/10.46661/lexsocial.5426.

326GURVITCH, G.: La Déclaration des Droits Sociaux, cit., págs.131 y sigs. 
los consumidores-usuarios de las naciones-miembros327. En este marco de constitución jurídica de la economía participada, el Consejo Nacional de Economía actuaría como un contra-poder del Parlamento político. En esta línea de pensamiento, entiende que ni los "consejos de control", ni los "consejos de gestión" funcionan efectivamente sin que la economía nacional sea planificada y particularmente nacionalizada. Los diferentes órganos de la democracia industrial sin la economía planificada no son más que sombras sin realidad. Y la economía planificada sin la democracia industrial no es más que un reforzamiento de la dominación y la opresión. En muchos aspectos, su propuesta se inserta dentro del modelo autogestionario, pero en el marco de un federalismo político y social de fuerte inspiración proudhoniana328. Es necesario, pues, que la democracia económica (que para él llevaría a la economía planificada y descentralizada) y la democracia industrial (democratización en el ámbito de las organizaciones de producción) se unan y se interpenetren, dando lugar a un sistema articulado y descentralizado de democratización de los procesos decisorios en materia económica329. En esta perspectiva socialista de propiciar la autogestión, la dirección participada de la economía general y el principio federalista, se podría dar una solución satisfactoria al problema de la democratización del poder en las sociedades contemporáneas. Gurvitch confiaba en que de modo gradual esas instituciones de democracia económica e industrial se consolidarían y llevarían a un sistema de socialismo democrático basado en el establecimientos de instituciones de participación directa de los individuos y grupos en todos los ámbitos de la vida social (en breve, organización económica democrática basada en la autogestión y el federalismo). Estas instituciones económicas, reconducibles según su modo de pensar a los "hechos normativos", realizarían por vías de Derecho los principios básicos del socialismo democrático.

En el tiempo que le tocó vivir pensaba que la única alternativa a la "crisis de la democracia"330 era el fascismo o un colectivismo descentralizado331; aunque la propuesta se construía desde una excesiva contraposición entre Estado y Sociedad, condicionada

327GURVITCH, G.: La Déclaration des Droits Sociaux, cit., pág.147.

328Véase GURVITCH, G.: Proudhon. Su vida, su obra, su filosofía, trad. J.Marfá, Madrid, Eds.Guadarrama, 1974; pero ya antes había expresado esa proximidad, en GURVITCH, G.: L'Idée du Droit Social. Notion et Système du Droit Social, París, Sirey, 1932 (reimpresión alemana de la edición de París de 1932, Scientia Verlag Aalen-1972), Tercera Parte, cap.II ("Teoría del "derecho económico" de Proudhon"), págs.370 a 406 . Interesa señalar la vinculación de la democracia económica con la transformación de la "constitución social". Consúltese PROUDHON, P.J.: Teoría del movimiento constitucional, trad. de Gavino Lizarraga, Madrid, Biblioteca Universal. Colección de los Mejores Autores, Dirección y Administración, 1873. Puede verse al respecto, en una perspectiva general, MONEREO PÉREZ, J.L.: Fundamentos doctrinales del Derecho Social en España, Madrid, Ed.Trotta, 1999.

329GURVITCH, G.: La Déclaration des Droits Sociaux, cit., pág.136.

330Puede verse al respecto DUVIGNAUD, J.: "Une philosophie du collectivisme décentralisé", en Qui a peur de l'autogestion?, París, U.G.E., 1978. Para la verificación del "clima" político que sirvió de medio ambiente a las reflexiones de Gurvitch sobre los fundamentos de una reforma en profundidad del sistema democrático pueden consultarse dos obras emblemáticas por su valor expresivo de la coyuntura y por su talante crítico en la valoración. LASKY, H.J.: La Democracia en Crisis, Madrid, Edersa, 1934; BAUER, O.: Capitalismo y socialismo en la postguerra, Madrid, Editorial España, 1932.

331Respecto a esa confianza hacia la instauración por vía pacífica del socialismo democratico puede verse DUVIGNAUD, J.: Gurvitch, symbolisme social et sociologie dynamique, París, Seghers, 1969, págs.70 y 156 y sigs. 
seguramente por el temor hacia el advenimiento de un Estado totalitario que colonizaría la sociedad civil (reduciendo la vida humana y la sociedad civil a la política institucional). Pero este miedo al poder político hacía en gran medida inviable el proyecto de democratización en una sociedad compleja y muy fracturada y, por ello mismo, necesitada de racionalización pública. Por otra parte, según Gurvitch los convenios colectivos de trabajo, que normalmente son competencia de los sindicatos, deben ser reglamentados por el Consejo Nacional Económico. Estos "actos-regla" son una especie de "cartas constitucionales especiales"332.

En realidad, toda esta propuesta democratizadora se realiza desde la premisa de que para él no se puede hacer triunfar la libertad humana en la esfera económica, sin abolir el poder del hombre sobre el hombre, impidiendo la transposición a las personas de las relaciones de poder del hombre sobre las cosas. En este sentido, la lucha contra la perversión del poder fundado sobre la propiedad individualista en un poder de dominación sobre los grupos y los individuos es ciertamente el objetivo esencial de toda verdadera Declaración de Derechos Sociales, como antes lo había sido del mismo proceso de socialización democrática de la economía333. En la Declaración se proclaman los valores superiores y las ideas jurídicas que están en la base constitutiva de la sociedad democrática. Para él proclamar no se contrapone a garantizar, ya que entiende que una Declaración de Derechos es el elemento más dinámico del Derecho escrito334, estableciendo, pues, un nexo jurídico y teleológico entre el instrumento jurídico de la Declaración y el sistema de Derecho positivo llamado efectivamente a garantizarla como realidad propiamente normativa.

La Declaración constituye un símbolo jurídico de la libertad humana que es preciso adaptar a las transformaciones de la sociedad democrática. Pero junto a ese valor jurídico, debe apreciarse también el enorme papel educativo de las declaraciones de derechos en un período de constantes reformas de las estructuras sociales335. De este modo para Gurvitch la esencia de la democracia no consiste en una simple transferencia del poder del pueblo al poder legítimamente constituido, sino en una participación activa de los individuos y de los grupos organizados en el proceso democrático. Básicamente para Gurvitch la democracia auténtica y el socialismo son la misma cosa, porque éste es el aspecto económico de la democracia y la condición que le permite desarrollar todas sus vitualidades integradoras al servicio de la realización de la libertad humana336. De ahí su defensa del principio de autogestión socialista que se contrapone al mismo tiempo al pensamiento liberal y a la teoría marxista originaria de inspiración más estatalista337. La expansión de la democracia tendría esta

332Véase GURVITCH, G.: La Déclaration des Droits Sociaux, cit., págs.150-151.

333GURVITCH, G.: La Déclaration des Droits Sociaux, cit., pág.160. Véase más específicamente su ensayo "Socialisme et propiété", en Revue de Métaphysique et de Morale, 1930, págs.128 y sigs.

334Esos valores e ideas reciben dentro del régimen democrático una expresión simbólica en las declaraciones de derechos, expresión adaptada a las estructuras sociales donde ellos deben ser realizados. Como todos los símbolos, las declaraciones son intermediarias entre el ideal y lo real y deben modificarse a fin de conservar toda su fuerza activa para que la realidad social cambie. Esa idea puede localizarse en GURVITCH, G.: La Déclaration des Droits Sociaux, cit., págs.46-47.

335En este sentido GURVITCH, G.: La Déclaration des Droits Sociaux, cit., pág.47.

336Véase BALANDIER, G.: Gurvitch, París, PUF, 1972, pág.46.

337Véase MIQUEL, J.: "Georges Gurvitch: Democratie quantitative et democratie qualitative", en Procès. 
significación participativa. En lo jurídico esta democracia participativa se expresaría formalmente a través de un nuevo tipo de Derecho, el Derecho social. Éste sería la pieza clave de la organización constitucional de la empresa y de la vida económica en su conjunto: un derecho de la sociedad expresivo de la pluralidad de las comunidades y grupos existentes en la sociedad democrática y no para la sociedad como es el propio del Derecho estatal configurado como una rama más de su propio ordenamiento interno338. El principio político-jurídico que desea realizar es el principio de autodeterminación jurídica de los grupos o autonomía iussocial de las comunidades sociales y el Derecho social autónomo es la expresión formal de ese poder sustancialmente normativo que ostentan los grupos sociales para autoorganizarse y autoreglamentar sus propios intereses parciales.

En el pensamiento de Gurvitch el ser humano es contemplado en la plenitud concreta de sus diversas manifestaciones. En esta dirección se distingue netamente el productor y más específicamente, el trabajador; el consumidor y el ciudadano. Pero las categorías de productor, consumidor y ciudadano, no agotan ni debilitan su ser: bajo el ciudadano, el productor y el consumidor, permanece el hombre integral o pleno independientemente de todas estas funciones específicas. Se trata de aspectos del ser humano. Cada uno de entre nosotros -dice Gurvitch- es a la vez ciudadano, productor y consumidor, pero la relación no suele ser armónica sino que está presidida por antinomias inherentes a la libertad humana y al pluralismo del ser humano. De manera que esa unidad no impide que los intereses de productores, consumidores y ciudadanos estén lejos de ser idénticos y sin fisuras. Al contrario, se oponen bajo todos los regímenes políticos y económicos -en todo sistema social- y deben ser equilibrados por técnicas especiales en vía de Derecho (juridificación de los procesos sociales). Esa dialéctica entre integración y antinomia preside cualquier tipo de sociedad histórica, incluida una futura sociedad socialista, apartándose en este punto respecto del pensamiento marxista que cree de forma utópica en la desaparición de conflictos de grupos después de la eliminación de la lucha de clases en la sociedad capitalista339. El

Cahiers d'analyse politique et juridique, monográfico sobre "Droit et agrégation sociale", núm.8 (1981), págs. 102 y sigs.

338En este sentido GURVITCH, G.: La Déclaration des Droits Sociaux, cit., pág.72.

339Véase GURVITCH, G.: La Déclaration des Droits Sociaux, cit., págs.66 y sigs. La Declaración propone una diferenciación de tres ámbitos de desenvolvimiento de los derechos sociales: $1^{\circ}$. La del ciudadano productor (derecho al trabajo, derechos del trabajo, derecho de libertad sindical), la del ciudadano consumidor (derechos a la subsistencia, a la distribución de la riqueza, a la seguridad económica, a la gestión de los servicios, etcétera) y la del ciudadano como persona integrada en la estructura de la sociedad (derechos de la personalidad como los derechos a la vida, a la educación, a la libertad de asociación general, de libertad profesional, etcétera). La estructura del "Proyecto de Declaración de los Derechos Sociales" es la siguiente: Preámbulo. I. Sección General. II. Los Derechos Sociales de los Productores. III. Los derechos Sociales de los ConsumidoresUsuarios. IV. Los deberes y los Derechos Sociales derivados de la propiedad. V. Los Derechos Sociales del Hombre ("Segunda Parte" de la obra de GURVITCH, G.: La Déclaration des Droits Sociaux, cit., págs.81 y sigs.). Con todo ello se trata de aplicar la concepción y técnica del pluralismo jurídico y social a la solución del problema de una Declaración de Derechos Sociales (Ibid., pág. 70). Su concepción del Derecho social no ignora la intervención de la Estado en la Política Social y en la legislación social, pero se resuelve primordialmente en un derecho social extraestatal autónomo nacido de la vida social de los grupos dentro de la comunidad social. Para ello recupera y tecnifica su propia noción de Derecho Social dentro de un cuadro eminentemente vinculado al fenómeno primordial del pluralismo jurídico en la vida real del derecho, que es una consecuencia del pluralismo de hecho en la realidad social. Cada grupo y cada conjunto social posee, en efecto, la capacidad de engendrar su propio orden jurídico autónomo que reglamenta su vida interior (Ibid., pág. 
proyecto del pluralismo jurídico y de la democracia social en Gurvitch constituye un nuevo paradigma de interconexión de "lo social", de "lo político" y de "lo jurídico" bajo la mirada de instaurar una nueva sociedad socialista democrática y participativa desde abajo y no sólo desde arriba; en otras palabras: de dimensión horizontal y no sólo vertical o estatalista (aunque también necesitada del Estado intervencionista en el marco del constitucionalismo democrático-social). Pretendía una nueva forma de integración democrática que respetara la unidad en la diferencia, es decir, la instauración de una democracia social pluralista y participativa en todos los ámbitos donde se desarrolla la personalidad de individuo y de las organizaciones y formaciones sociales de pertenencia340.

Con base a esas diversas dimensiones del hombre en la sociedad, Gurvitch estructura su proyecto de Declaración de los Derechos Sociales, dividiendo la Declaración lógicamente en derechos sociales de los productores, de los consumidores y del hombre. Entiende que tales derechos equilibran y completan los derechos políticos de los ciudadanos, y en ningún caso los sustituyen. Con ese cuadro general aplica la nueva técnica pluralista a la solución del problema de una Declaración de derechos sociales341.

\section{El principio democrático y la idea del Derecho social}

Gurvitch establece una indisociable conexión entre el principio democrático y el Derecho social, que para él sería una expresión de la democracia. Por ello afirma que el derecho social es la esencia misma de la democracia342. Para él el Derecho social es la esencia misma de la democracia. Simboliza jurídicamente y encarna en sí la idea de autogobierno colectivo a base de igualdad y de libertad. La democracia es el Derecho social organizado, la soberanía del Derecho social es la democracia. Más ampliamente, la democracia y el Derecho son las dos facetas de un mismo fenómeno. Es la intensificación y la actualización de la experiencia jurídica la que conduce a la democracia343. Reflexión que pone de manifiesto la conexión del pluralismo jurídico con el pluralismo político, con la democracia pluralista. Gurvitch es, en efecto, un acérrimo defensor de la democracia pluralista344, donde la sociedad se exprese

72., y ampliamente especificando y materializando esta idea, págs. 71-80).

Se trata para él de garantizar un conjunto de derechos sociales que se despliega en todas las esferas donde se desarrolla la personalidad del individuo en una sociedad democrática pluralista, en la cual existe un sistema de contrapesos y equilibrios entre la dinámica de los grupos sociales y la organización política del Estado, el cual no debe absorber a la sociedad civil pluralista y a la participación de los individuos y grupos en la esfera pública y asimismo en el proceso de tomas de decisiones políticas. Aquí el pluralismo es pensado como "hecho", como "ideal” y como "técnica" (Ibid., págs. 58 y sigs.).

340 En este sentido GURVITCH, G.: La déclaration des droits sociaux, New Yord, La Maison Française, 1944, pág. 68.

341El texto del "Proyecto de Declaración de los derechos sociales" se recoge en la parte segunda de su obra GURVITCH, G.: La Déclaration des Droits Sociaux, cit., págs.81 y sigs.

342L'Expérience Juridique et la Philosophie Pluraliste du Droit, París, Pedone, 1935, pág.263. En el mismo sentido GURVITCH, G.: "Le principe démocratique et la démocratie future" (1927), estudio incluido en L'Expérience Juridique et la Philosophie Pluraliste du Droit, París, Pedone, 1935, págs. 235 y sigs., en particular pág.263: "El Derecho social -escribe- es la esencia misma de la democracia. Simboliza jurídicamente y encarna en sí la idea de autogobierno colectivo (self-government collectif) a base de igualdad y de libertad".

343L'Expérience Juridique et la Philosophie Pluraliste du Droit, París, Pedone, 1935, pág.254.

344L'Expérience Juridique et la Philosophie Pluraliste du Droit, París, Pedone, 1935, págs.254 y sigs. 
en toda su diversidad. Para él, la democracia pluralista sería un régimen socialista345 y piensa que la tendencia hacia la democracia pluralista es la más favorable a una cultura jurídica, a la salvaguardia de la autonomía del Derecho con relación a otras esferas de la vida social. Este sistema del Derecho de la sociedad pluralista y socialista sería un Derecho flexible y móvil fuertemente asentado en la misma sociedad organizada346.

En esa línea de pensamiento considera esencial establecer una democracia pluralista participada no basada en el principio de subordinación, sino en el de integración que informa al Derecho social, señaladamente a través de la creación de mecanismos institucionales de participación en la dirección de la economía nacional (fórmula de los Consejos económicos de la experiencia de Weimar) y de cauces de participación en la vida de las empresas (democracia de productores o "democracia industrial"). Estas fórmulas de democracia económica serían paralelas a la democracia política347. Hasta tal punto es así que para Gurvitch el futuro de la democracia está en la universalidad y la multiplicidad de sus facetas (faces), en su carácter, para así decir poliédrico, en su extensión continua a nuevas regiones de relaciones humanas348. Considera que es necesario potenciar la tendencia de la sociedad actual global a reforzar el elemento de la comunidad, en la "sociedad económica" (que él utiliza como expresión próxima a la "sociedad civil"), por la integración de los grupos de productores y de consumidores en el conjunto; dicha integración tiene como base un ordenamiento del derecho social económico común independiente, que es equivalente en su validez al ordenamiento del Derecho estatal. Para Gurvitch, ello presupone la organización autónoma de la sociedad económica en una gran asociación federativa de colaboración. Desde el punto de vista institucional, los órganos de la democracia económico-social construirían una red formada por los consejos de fábrica hasta el Consejo Nacional Económico y un sistema de propiedad industrial, agraria y financiera, federalizada y mutualizada. Se trata de la instauración de la "economía dirigida" sometida al la supervisión directa de los interesados. Su puesta en práctica llevaría a la implantación de una auténtica democracia pluralista, que para Gurvitch supondría establecer un equilibrio jurídico entre el bloque de los "grupos de localidad-Estado", y el bloque de los "grupos de actividad económica". Por lo demás, ese proceso de democratización evitaría las tendencias totalitarias349.

Por otra parte, para él la democracia no tiene que estar necesariamente centralizada, en el sistema institucional del Estado puede desarrollarse en todos los ámbitos de la vida social350. Para Gurvitch "la democracia es el derecho social organizado; la soberanía del derecho social es la democracia". Esta definición permite hacerse una idea exacta de cuáles son las formas "no-políticas" (no exclusivamente estatales...) de la democracia, en particular:

345Expresamente, Véase GURVITCH, G.: Elementos de sociología jurídica, cit., pág.230.

346Véase Véase GURVITCH, G.: Elementos de sociología jurídica, cit., págs.230-231.

347L'Expérience Juridique et la Philosophie Pluraliste du Droit, París, Pedone, 1935, pág.255 y sigs.

348Ibidem.

349Véase GURVITCH, G.: Elementos de sociología jurídica, cit., págs.229-230 y 239.

350Véase L'Expérience Juridique et la Philosophie Pluraliste du Droit, París, Pedone, 1935, págs.259 y sigs. 
la democracia económica e industrial351. De ahí la lucha por la democratización de todas las instituciones sociales y políticas. Pero esa lucha por el derecho exige que las constituciones jurídicas reconozcan a las colectividades menores, a los sujetos colectivos, y reconozcan también sus derechos colectivos. En la postguerra pensaba Gurvitch que la democracia exigía una serie de garantías de los derechos y libertades fundamentales, cuyo catálogo debería enriquecerse a escala internacional a través de la proclamación de una Declaración de los Derechos Sociales. Esta "carta constitucional" de derechos, unida al reconocimiento del estandard de derechos fundamentales clásicos, permitiría hacer frente a las amenazas planteadas por los regímenes totalitarios352. Defiende el Estado social y democrático de Derecho y su compromiso en la realización de la justicia social (y en general de los valores fundamentales del ordenamiento jurídico), pero desconfía de toda desaparición del poder constituyente residenciado en la sociedad civil y en las agrupaciones sociales que operan en su interior. Pero considera que la sociedad económica abandonada a sí misma, conduciría al sometimiento de los más débiles a las estructuras de dominio353.

De este modo el pluralismo jurídico converge con la renovación del movimiento de reforma constitucional que postularía la inclusión de derechos de participación política y social; todo un catálogo de derechos sociales fundamentales garantizados al máximo nivel, que no sólo establezcan compromisos del poder público respecto de los individuos y grupos sociales, sino también un haz de derechos que permitan una autoorganización de la sociedad civil que evite todo riesgo de su absorción en las estructuras institucionales de cualquier Estado autoritario354. Esta es la misión política y "constitucional" del Derecho social en cuanto derecho de integración o interpenetración de la sociedad como verdadera comunidad política organizada355. Precisamente es rasgo esencial del Derecho social de la democracia

351L'Expérience Juridique et la Philosophie Pluraliste du Droit, París, Pedone, 1935, pág.264.

352Arendt tenía una preocupación análoga, véase su obra, ARENDT, H.: Los orígenes del totalitarismo (1948), 2 vols., Barcelona, Planeta-Agostini, 1994. Sobre su pensamiento respecto a los derechos humanos y el régimen político, véase LAFER, C.: La reconstrucción de los derechos humanos. Un diálogo con el pensamiento de Hannah Arendt, México, FCE, 1994. También el segundo Radbruch, como puede comprobarse en MONEREO PÉREZ, J.L.: "La filosofía de Gustav Radbruch: Una lectura jurídica y política", Estudio Preliminar a RADBRUCH, G.: Filosofía del Derecho, Granada, Ed.Comares (Col. Crítica del Derecho), 1999, XVII a CLX; ampliamente, MONEREO PÉREZ, J.L: El Derecho en la Democracia Constitucional. La teoría crítica del Gustav Radbruch, Barcelona, Ediciones de Intervención Cultural/El Viejo Topo, 2020.

353Véase GURVITCH, G.: Elementos de sociología jurídica, cit., Introducción, págs.227 y sigs.

354Para este planteamiento, véase también POSADA, A.: La reforma constitucional, Madrid, Librería General de Victoriano Suárez, 1931; POSADA, A.: La nouvelle Constitution espagnole, París, 1932; POSADA, A.: Teoría social y jurídica del Estado. El Sindicalismo (1922), edición y estudio preliminar a cargo de J.L. Monereo Pérez, Granada, Ed. Comares (Col. Crítica del Derecho), 2018. Puede consultarse al respecto y atendiendo al clima cultural de su época, MONEREO PÉREZ, J.L: Fundamentos doctrinales del Derecho Social en España, Madrid, Editorial Trotta, 1999, espec., Cap. 3 ("La formación del Derecho Social y el socialismo jurídoco en España: El socialismo jurídico en la formación del Derecho Social”), págs. 87 y sigs.; MONEREO PÉREZ, J.L.: "El pensamiento jurídico-social de Fernando de los Ríos y su generación". en CÁMARA VILlAR, G. (ed.): Fernando de los Ríos y su tiempo, Granada, Universidad de Granada, 2000. Consúltese también la perspectiva de conjunto que ofrecen PULARD y MIRKINE-GUETZEVITCH: Les Déclarations des Droits de l'homme, París, 1929; MIRKINE-GUETZEVITCH, B.: Modernas tendencias del Derecho Constitucional, trad. S.Álvarez Gendin, Madrid, Ed.Reuss, 1934.

355Véase GURVITCH, G.: L'Idée du Droit Social, cit., Primera Parte, caps.II ("Notion du droit social") y IV ("Les prémisses systématiques de la notion du droit social"), págs. 15 y sigs. y 95 y sigs. 
constitucional el ser un Derecho de integración que instituye un "poder social" como poder legítimo356.

Es un sentir de la época insertar las Declaraciones de derechos sociales como un problema de democratización y racionalización del poder y como una continuidad y complementación de los "Derechos del Hombre y del Ciudadano", que datan de las Revoluciones Francesa y Americana, y que surge y alcanza su perfeccionamiento lógico en las nuevas Constituciones357. Es ésta una tendencia a la racionalización democrática de la sociedad, que se construye desde la introducción de elementos sociales en las Declaraciones constitucionales de derechos, lo que se ha producido en un período histórico en que nadie podía desconocer la "cuestión social". Las transformaciones de la sociedad moderna y la penetración del espíritu democrático determinan que el poder público no puede limitarse a reconocer la autonomía jurídica del individuo; ha de establecer un mínimo de condiciones necesarias para asegurar la independencia social y su participación activa en la dinámica de la sociedad. Es el lugar propio del Derecho democrático. Hay que tener en cuenta que los derechos sociales no eran extraños a la conciencia jurídica de los hombres de la Revolución Francesa. Por una parte, las Declaraciones de 1789 y 1793 encerraban ya, junto a los derechos negativos, obligaciones positivas del Estado en lo concerniente a la instrucción

356GURVITCH, G.: L'Idée du Droit Social, cit., pág.15.

357Véase MIRKINE-GUETZEVITCH, B.: Modernas tendencias del Derecho Constitucional, trad. S.Álvarez Gendin, Madrid, Ed.Reuss, 1934, caps.I y III. Existe una persistente tensión entre la concepción individualista y el concepto solidarista de las libertades individuales. En tal sentido, el Estado contemporáneo está limitado por tener un deber objetivo con relación a los ciudadanos: interesa poco que haya o no un Derecho subjetivo del individuo; lo esencial es sentar que existe un deber objetivo del Estado. Para la visión del solidarismo jurídico de Duguit, véase DUGUIT, L.: La transformación del Estado, Madrid, Francisco Beltrán, Librería Española y Extranjera, s/f (1909), trad. seguida de un estudio sobre La nueva orientación del Derecho Político, por Adolfo Posada. DUGUIT, L.: Las transformaciones del Derecho Público y Privado, edición crítica y estudio preliminar, "Objetivismo jurídico y teoría de los derechos en León Duguit" (pp.XIXXXIX), a cargo de J.L. Monereo Pérez y J. Calvo González, Granada, Ed. Comares (Col. Crítica del Derecho), 2007. DUGUIT, L.: Manual de Derecho Constitucional, edición crítica y estudio preliminar, «La teoría jurídica de León Duguit», a cargo de J.L.Monereo Pérez y J. Calvo González, Granada, Ed. Comares (Col. Crítica del Derecho), 2005; DUGUIT, L.: Soberanía y Libertad. Lecciones dadas en la Universidad de Columbia (New York, 1920-1921), traducción y prólogo de José G. Acuña y revisión, edición y estudio preliminar a cargo de J. L. Monereo Pérez, Granada, Ed. Comares (Col. Crítica del Derecho), 2013. Esta edición culmina con un ensayo de OTTO KIRCHHEIMER, En busca de la soberanía, que apareció bajo el título "In Quest of Sovereignty", en Journal of Politics, 6 (1944). 
pública y a la asistencia social358. Por su parte, la Constitución de 1848 fue más allá al consagrar el principio de la protección del trabajo359.

Dentro de su esquema de pensamiento, Gurvitch dará un paso más para hacer notar que la fórmula jurídica del socialismo sería, en coherencia discursiva, perfectamente idéntica a la fórmula de la democracia, es decir, es la soberanía del Derecho social como derecho de integración transpersonal. Por ello, la democracia y el socialismo no necesitan ser conciliadas, porque de partida, la democracia y el socialismo, en su verdadera acepción de socialismo democrático y pluralista, representan una sola y misma cosa. Para él, el socialismo es una dimensión o aspecto intrínseco de la democracia contemporánea (la democracia política y social). Es más, concretamente, es el aspecto económico de la democracia360. En el fondo, piensa que la democracia no puede desplegar su verdadera esencia y sus múltiples fuerzas potenciales mientras permanezca cautiva del individualismo liberal. Lo cual confirma su tesis de que el futuro de la democracia está en la multiplicidad de sus facetas y en su carácter pluralista361. Nuestro autor acaba aceptando -al modo en que lo había expresado Jean Jaurès en Francia, Sidney y Beatrice Webb, G.D.H. Cole, y Harold Laski, en el laborismo inglés- una síntesis entre Marx y Proudhon, al proponer que la propiedad de los medios de producción fuera atribuida a un Estado colectivista, pero que la posesión y el control efectivo de esos medios en el marco de las organizaciones económicas

358Aunque no triunfara el "Proyecto de Robespierre" en la Declaración de 1793 ("Proyecto de Declaración de los Derechos del Hombre y del Ciudadano, presentada por Maximiliano Robespierre a la Sociedad de los Jacobinos el 21 de Abril de 1793, y adoptado por esta entidad"). Dicha Declaración recogía un conjunto de disposiciones entre las que interesa hacer constar las siguientes: "Art. $7^{\circ}$. La propiedad es el derecho que tiene cada ciudadano de gozar y disponer de la porción de bienes que le está garantizada por la ley. Art. $8^{\circ}$. El derecho de propiedad está limitado, como los otros, por la obligación de respetar los derechos ajenos. Art. $9^{\circ}$. No puede perjudicar a la seguridad, a la libertad, a la existencia, ni a la propiedad de nuestros semejantes. Art. $10^{\circ}$. Toda posesión, todo tráfico que viole este principio es esencialmente ilícito e inmoral. Art.11 $1^{\circ}$. La sociedad está obligada a subvenir a la subsistencia de todos sus miembros, ya procurándoles trabajo, ya asegurando medios de existencia a quienes no estén en condiciones de trabajar. Art. $12^{\circ}$. El socorrer necesariamente a la indigencia es una deuda de los ricos para con los pobres, correspondiendo a la ley determinar el modo en que esta obligación habrá de ser cumplida. Art.13․ Los ciudadanos cuayos ingresos no excedan de lo necesario para vivir quedan dispensados de contribuir a los gastos públicos. Los demás deben soportarlos progresivamente según la importancia de su fortuna. Art.14 ${ }^{\circ}$. La sociedad de deber favorecer por todos sus medios el progreso de la inteligencia, colocando la instrucción pública al alcance de todos los ciudadanos".

359Por otra parte, en el plano filosófico conviene tener en cuenta, aparte de la aportación de los socialistas utópicos, la filosofía socialista de FICHTE, J.G.: El Estado comercial cerrado (1800), con estudio preliminar, traducción y notas de J.Franco Barrio, Madrid, Ed. Tecnos, 1991, donde plantea el derecho a la existencia de todo hombre y el compromiso del Estado de garantizarlo plenamente. Sobre el tema puede consultarse HELLER, H.: Las ideas políticas contemporáneas, Barcelona, Ed.Labor, 1930 (Reditada HELLER,H.: Las ideas políticas contemporáneas, edición y estudio preliminar a cargo de J.L. Monereo Pérez, Editorial Comares, Col. Crítica del Derecho, Granada, 2004), espec., Sección Séptima ("Las ideas socialistas"), págs.150 y sigs., que, por lo demás, ya apuntó que al contrario de lo que ocurre en la política constitucional, la política social sólo podrá tener éxito si es internacional. Solamente un "Estado comercial cerrado", ingenua utopía dentro de un mundo de imperialismo económico-universal, no tendría que temer que la gran carga social de su industria impidiera a ésta competir con éxito en los mercados mundiales (Ibid., 187). Un planteamiento cuya exactitud ha sido realzada con la globalización de la economía mundial en el Estado comercial "abierto" del tiempo presente.

360L'Expérience Juridique et la Philosophie Pluraliste du Droit, París, Pedone, 1935, pág.265.

361Explícitamente, L'Expérience Juridique et la Philosophie Pluraliste du Droit, París, Pedone, 1935, pág.265. 
fueran atribuidos a los trabajadores en autogestión. Es así que Gurvitch se inclina por la instauración de un colectivismo descentralizado, basado en la autogestión obrera362.

Para Gurvitch el Derecho social es el Derecho del socialismo democrático. Para él la democracia es el Derecho social organizado, siendo pues la fórmula del socialismo "idéntica a la fórmula de la democracia, es, por tanto, la soberanía del Derecho social. Democracia y socialismo, en su verdadera acepción, no tienen necesidad de ser conciliados: representan una sola y misma cosa. El socialismo es el aspecto económico de la democracia y la democracia no podrá aplicar su verdadera esencia y sus múltiples fuerzas potenciales mientras permanezca esclava del individualismo"363. En muchos aspectos Gurvitch se vincula con la tradición del socialismo en el Derecho364.

Todo ello se comprende fácilmente cuando se parte de la concepción de que el socialismo, en el sentido más amplio de la expresión, es un sistema de organización racional de la economía que se propone la supresión del poder del hombre sobre el hombre en la medida en que este poder deriva de las relaciones de propiedad de cualquier signo. El socialismo combate exclusivamente la perversión del poder del hombre sobre las cosas en un poder del hombre sobre el hombre365. Del mismo modo que apuesta por una organización política de tipo federalista, Gurvitch considera necesario para el establecimiento de una democracia político-social instaurar un sistema de propiedad federalista que pondría límites precisos al poder jurídico-político detentado por el Estado o poder público. Un modo de pensar que, sin duda, es tributario del pensamiento de Proudhon, pensador proclive a la instauración de formas de democracia y de propiedad federalista366. Esta posición refleja su oposición al estatismo exagerado de la socialdemocracia de su tiempo, considerando necesario establecer un equilibrio entre el poder político institucional y el poder socio-económico emergente de modo pluralista dentro de la sociedad civil.

Sin embargo, Gurvitch no incurrió en la ingenuidad, ni en el extremismo, de pensar que pudiera establecerse ilimitadamente un colectivismo descentralizador367, una democracia

362En este sentido Gurvitch, no ocultando sus simpatías por la doctrina de Proudhon, habla significativamente de "revancha de Proudhon", retomando sus propias posiciones durante la revolución en Rusia. Cfr. GURVITCH, G.: Proudhon. Su vida, su obra, su filosofía, trad.J.Marfá, Madrid, Ed. Guadarrama, 1974, págs.68 a 70, espec. Hace notar que "el espantoso peligro de la tecnocracia al servicio de los trust y de los cartels privados, nacionales o internacionales, tecnocracia que asegura el dominio de estos últimos sobre el Estado y su administración, hace que el problema de la autogestión obrera sea de gran actualidad. Cien años sigue diciendo- después de su muerte, la actualidad de Proudhon se impone tanto en el "este" como en el "oeste". Este es, en mi opinión, el mayor homenaje que se le puede rendir" (Ibid., 70).

363L'Expérience Juridique et la Philosophie Pluraliste du Droit, París, Pedone, 1935, págs.264-265.

364Apunta oportunamente Treves que existen puntos de conexión innegables entre el socialismo liberal y democrático de Gurvitch y el defendido en Italia por Carlo Rosselli. Para comprobarlo se apoya en el ensayo de GURVITCH, G.: "I sindicati e l'interese generale", con una nota no firmada, pero de Carlos Rosselli, en Quaderno 10 di Giustizia e Libertà, febrero, 1934, reimpresión en Turín, 1959, págs.29 a 36; GAROSCI, A.: La vita di Carlo Rosselli, vol.II., Florencia, 1945, pág.80.

365L'Expérience Juridique et la Philosophie Pluraliste du Droit, París, Pedone, 1935, págs.266 y sigs. ("Socialismo y propiedad").

366Véase esa confluencia de pensamiento en GURVITCH, G.: Proudhon. Su vida, su obra, su filosofía, trad.J.Marfá, Madrid, Ed. Guadarrama, 1974, passim.

367L'Expérience Juridique et la Philosophie Pluraliste du Droit, París, Pedone, 1935, págs.278 y sigs. Id.: 
sindicalista368 o la construcción de un socialismo de "guildas". Para Gurvitch el proceso de "socialización" remite a la puesta en práctica de la idea del equilibrio entre el Estado y la "propiedad federalista". En este sentido cree que el Derecho social de los cuerpos económicos y sociales, compuesto sobre una base paritaria de sindicatos de productores y de cooperativas de consumidores, puede devenir capaz de organizar la producción nacional y de afirmar su independencia respecto del Estado, apoyándose sobre la fuerza elemental de la propiedad, puesta a su servicio; puede gradualmente contribuir a establecer una teoría y una praxis positiva de socialización. En este marco el sentido verdadero del socialismo democrático no puede ser más que una filosofía pluralista del Derecho y de la Sociedad como un todo369. Es así que podría hacérsele decir, con Habermas, que la democracia en sí es una forma de integración política jurídicamente mediada370; y para conseguirla apuesta por un socialismo democrático instaurado a través de un proceso de reformas estructurales y de transformación de las mentalidades.

En ese proceso de reformismo político y iussocialista considera necesario avanzar hacia la auténtica configuración del Derecho del Estado democrático como verdadero Derecho social de integración. Él caracteriza al Estado democrático como una asociación de colaboración y a su Derecho como un auténtico Derecho social371. Atribuye al Estado democrático dos rasgos esenciales: en primer lugar, el Estado o poder público como persona básica de organización de la comunidad política no tiene por función absorber o neutralizar las personalidades parciales, de las instituciones y de los individuos que forman parte de la sociedad organizada. En segundo lugar, en el modelo de Estado democrático existe una íntima interacción entre el poder institucional y la comunidad política que subyace a la propia estructura social organizada. Ello supone que Gurvitch proclama la primacía de la soberanía del derecho social de la comunidad política subyacente respecto a la misma estructura política institucional (estatal o pública) por ella construida. Ello diferencia a Gurvitch de todo pensamiento estatalista o centralista que reconduce el problema de la organización política democrática hacia una pura estructura de dominación, la cual estaría formalizada y regulada a través de un "derecho de subordinación" de las colectividades y de los individuos respecto de la voluntad de dominio ejercida desde el monopolio del poder.

\footnotetext{
L'idée du droit sociale, cit., págs.39 y sigs.

368L'Expérience Juridique et la Philosophie Pluraliste du Droit, París, Pedone, 1935, págs.282 y sigs.

369L'Expérience Juridique et la Philosophie Pluraliste du Droit, cit., pág.296.

370HABERMAS, J.: Facticidad y validez, cit., passim.; explícitamente, HABERMAS, J.: "El valle de lágrimas de la globalización", en Claves, núm.109 (Enero/Febrero 2001), pág.10.

371Cfr. La idea del Derecho social, cit., págs.35 y 83 y sigs. Para él el paradigma del Estado democrático supone que éste adopta la estructura de una "asociación de colaboración" (sujeto de derecho social organizado), apartándose de toda idea de "asociación" o "estructura" de dominación.
} 


\section{Bibliografía}

\section{1. Obras seleccionadas de Georges Gurvitch y traducciones al español}

GURVITCH, G.: Écrits russes: Écrits de jeunesse, Edición en Francés, trad. Cécile Rol et Mikhail Antonov, Paris, Editorial, Editions L'Harmattan, 2006.

GURVITCH, G.: « Tout le pouvoir aux soviets! », Le recueil des articles sur la révolution prolétarienne et le droit [Sbornik statei po proletarskoi revolutsii i pravu], 1-4, 1918, Petrograd, págs. 1-21 [en Ruso original]).

GURVITCH, G.: Rousseau et la déclaration des droits, Petrograd, Izdatelstvo Volfa, 1918, págs. 97 y sigs. [en Ruso original].

GURVITCH, G.: Otto Von Gierke als Rechtsphilosph, Tübingen, J.C.B. Mohr, 1922.

GURVITCH, G.:”Otto von Gierke als Rechtsphilosoph”, Logos, XI, 1922-1923, págs. 86-132.

GURVITCH, G.: “Les syndicats et l' intérêt général”, en L' Homme réel, no . 1, 1934.

GURVITCH, G.: “Le plan et la démocratie industrielle”, en L' Homme réal, n’. 12, 1934.

GURVITCH, G.: «L'État et le socialisme », Annales contemporaines, 25, 1925 [en Ruso Original].

GURVITCH, G.: «Proudhon et le temps présent », Annales contemporaines, 30, 1927 [en Ruso originale].

GURVITCH, G.: « Socialisme et propriété », Annales contemporaines, 36, 1928 [en Ruso original].

GURVITCH, G.: Introducción a la Teoría General del Derecho Internacional, Paraga, Facultad de Derecho, Ruso, 1923 (en ruso).

GURVITCH, G.: Fichtes System der Konkreten Ethik, Tübingen, J.C. B. Mohr (Paul Siebeck), 1924.

GURVITCH, G.: Die Einheit der Fichteschen Philosophie. Personal und Gemeinschaftwert in der Ethik Fichtes. Eine Studie über Fichtes Lehere vom sttlichen Ideal. I. Lieferung, Berlin, Verlag A.Collignon, 1922.

GURVITCH, G.: Die Einheit der Fichteschen Philoso-phie. Personal und Gemeinschaftwert in der Ethik Fichtes. Eine Studie über Fichtes Lehre vom sittlichen Ideal. I. Lieferung, Berlin, Verlag A.Collignon, 1922; Ibid., Fichtes System der konkreten Ethik, Tübingen, Mohr, 1924.

GURVITCH, G.: Les tendences actuelles de la Philosophie Allemande. E.Husserl, M. Scheler, E. Lask, N. Hartmann, M. Heidegger, Préface de Léon Brunschvig, París, Vrin, 1930.

GURVITCH, G.: "Une philosophie intuitionniste du droit: Léon Pétrasycki», Archives de philosophie du droit et de sociologie juridique, 3-4 (1931), págs. 403-420.

GURVITCH, G.: "Kant und Fichte als Rousseau Interpreten", en Kantstudien, Band XXVII, 1922, págs.138 a 164. Traducción francesa en Revue de Métaphysique et de Morale, núm. 76 (1971), págs.385 a 405. 
GURVITCH, G.: Fichtes System der Konkreten Ethik, Tübingen, J.C.B. Mohr, 1924 (reimpr.: Hildesheim-Zürich-New York, Georg Olms Verlag, 1984).

GURVITCH, G.: Morale Théorique et Science des Moeurs: leur possibilités, leurs conditions (1937), París, PUF, $3^{\text {a }}$ ed., 1961, cap.II.4º, Sección, págs.88-89.

GURVITCH, G.: Les Tendences Actuelles de la Philosophie Allemande. E.Husserl, M.Scheler, E.Lask, N.Hartmann, M.Heidegger, Préface de Léon Brunschvig, París, Vrin, 1930.

GURVITCH, G.: Les tendances actuelles de la philosophie allemande (E. Husserl, M. Séller, E.Lask, N.Hartmann, M. Heidegger), Préface de Léon Brunschvicg, $1^{\mathrm{a}}$ ed., París, ed. Vrin; $2^{a}$ ed., 1949. Traducción castellana: Las tendencias actuales de la filosofía alemana, trad. F. Almela y Vives, Madrid, M.Aguilar-Editor, 1931, y varias traducciones realizadas en Argentina de 1939 y 1944.

GURVITCH, G.: L'idée du Droit Social. Notion et système du Droit Social. Histoire doctrinale depues le XII siègle jusqu`a la fin du XIX siègle, París, Libraire Du Recueil Sirey, 1932 (reimpresión alemana, Darmstadt, Scientia Verlag Aalen, 1972). Traducida por primera y única vez al castellano, La Idea del Derecho Social. Noción y Sistema del Derecho Social. Historia Doctrinal Desde El Siglo XVII Hasta El Fin Del Siglo XIX, traducción, edición y Estudio preliminar, "La idea del derecho social en la teoría general de los derechos: El pensamiento de Gurvitch" (pp. VII-LV), de J.L.Monereo Pérez y A. Márquez Prieto, Editorial Comares (Col. Crítica del Derecho), 2005, 782 páginas.

GURVITCH, G.: Le Temps Présent et l' Idée du Droit Social, Préface de Máxime Leroy, París, Librairie Philosophique J.Vrin, 1932.

GURVITCH, G.: 'Reseña: de Adolfo Posada, Les fonction sociales de l' Etat, París, Girard, 1929", en Archives de philosophie du droit et de sociologie juridique, III, 1933, págs. 223-226.

GURVITCH, G.: "Droit naturel ou droit positf intuitif”, en Archives de Philosophie du Droit et de Sociologie Juridieuqe, Cahiers, núm.3-4, 1933, págs.55 a 90.

GURVITCH, G.: "L' Evolution de la "Doctrine de la Science" chez Fichte, d' aprés M.Guéroult (M.Guéroult, L' Evolution et la Structure de la Doctrine de la Science chez Fichte, 2 t., París, Les Belles Letres, 1930), en Revue de Métaphysique et de Morale, núm.40 (1933), págs.119 a 128.

GURVITCH, G.: “Les syndicats et l' intérêt général”, en L' Homme réel, no. 1, 1934, págs. 13-19.

GURVITCH, G.: “Le plan et la démocratie industrielle”, en L'Homme réal, no. 12, 1934.

GURVITCH, G.: "Remarques sur les formes de sociabilité", en Archives de Philosophie du droit et de sociologie juridique, núms.3-4 (1935), págs.43 a 91.

GURVITCH, G.: "La répresentation ouvrière et le problème des nationalisations: "conseils de contröle" et "conseils de gestion", en Esprit, 1 Javier, 1946, págs. 107-112.

GURVITCH, G.: “Vers 1' unité ourière”, en Esprit, 14, $1^{\text { }}$ Février, 1946, págs. 270-279.

GURVITCH, G.: "Les voies de la démocratisation industrielle", en Esprit, Juin, 1953, págs. 964-972. 
GURVITCH, G.: "Théorie pluraliste des sources du droit positif", en Annuaire de l' Institut International de Philosophie du Droit et de Sociologie Juridique, 1934-1935, págs.114 a 131.

GURVITCH, G.: L'Expérience Juridique Et la Philosophie Pluraliste Du Droit, París, Editions A. Pedone, 1935.

GURVITCH, G.: "Remarques sur les formes de sociabilité", en Archives de Philosophie du droit et de sociologie juridique, núms. 3-4 (1935), págs.43 a 91.

GURVITCH, G.: "Compte rendu: Gaston Richard. La Conscience morale et l' Expérience morales; les Lois morales, les Lois naturelles et les Lois socials, 1937, París, éd. Hermann", Archives de Philosophie du Droit et de Sociologie Juridique, Cahiers, núm.12 (1938), págs.276 a 278.

GURVITCH, G.: Essais de Sociologie, París, ed. Du Recueil Sirey, 1938.

GURVITCH, G.: Les fondateurs de la sociologie contemporaine. Trois chapitres d' histoire de la sociologie. Auguste Comte, Karl Marx et Herbert Spencer, Paris, Centre de Documentation Universitaire, 1958.

GURVITCH, G.: La multiplicité des temps sociaux, París, Centre de Documentation Universitaire, 1958 ( $2^{\mathrm{a}}$ ed., 1961).

GURVITCH, G.: Pour le centenaire de la mort de P.J. Proudhon: Proudhon y Marx, une confrontation, París, Centre de Documentation Universitaire, 1964.

GURVITCH, G.: Proudhon, su vie, son oeuvre, París, PUF, 1964.

GURVITCH, G.: C.H. de Saint-Simon. La physiologie sociale, ed., cargo de G. Gurvitch, con una Introducción y Notas, París, PUF, 1965.

GURVITCH, G.: Les Cadres Sociaux de la Connaissance, París, PUF, 1966.

GURVITCH, G.: Études sur les clases sociales, París, Denoël-Gonthier, 1966.

GURVITCH, G.: Morale Théorique et science des moeurs. Leurs possibilities.- Leurs conditions, $1^{\text {a }}$ ed., Paris, Alcan, 1937; $2^{\text {a }}$ ed., París, PUF, 1948, $3^{\text {a }}$ ed., revisada, París, PUF, 1961.

GURVITCH, G.: «Mon itinéraire intellectuel ou l'exclu de la horde», in Georges Balandier, Georges Gurvitch, sa vie, son œuvre, Paris: PUF, 1972.

GURVITCH, G.: Élément de sociologie juridique, París, Éditions Aubier Montaigne, 1940. Edición alemana con prefacio del autor: Grundzüge der Soziologie des Rechts, Neuwied, 1969. Versiones en Castellano: Argentina: Elementos de Sociología Jurídica, Buenos Aires, Cajica, 1965. España: Elementos de Sociología Jurídica, Edición crítica española y Estudio preliminar, "Pluralismo jurídico y Derecho Social: La sociología del Derecho de Gurvitch" (pp.XIII-CXLVI), a cargo de J.L.Monereo Pérez, Granada, Ed.Comares (Col. Crítica del Derecho), 2001.

GURVITCH, G.: Las formas de sociabilidad, traducción de Francisco Ayala, Buenos Aires, Ed.Losada, 1941.

GURVITCH, G.: Sociology of Law, with preface of Roscoe Pound, New York-London, Philosophical Library and Alliance Book Corporation, 1942; $2^{\mathrm{a}}$ ed., inglesa, LondonBoston, Toutledge \& Kegan Paul, 1947. Traducción Argentina: Sociología del Derecho, 
Rosario-Santa Fe (Argentina), Editorial Rosario, trad. De Ángela Romera Vera, 1945. También en Buenos Aires, Ed.Depalma, 1945.

GURVITCH, G.: La déclaration dês droits sociaux, New York, Éditions de la Maison Française, 1944; 2a ed., en París, Librairie Philosophique J. Vrin, 1946.

GURVITCH, G.: Sociology of Law, With a preface by Roscoe Pound York, Philosophical Library and Alliance Book Corporation, 1942 (ed. Inflesa, London Kegan Paul, 1947). Sociología del Derecho, Buenos Aires, Ed. Rosario, 1945.

GURVITCH, G.: Initiation aux Recherches sur la Sociologie de la Connaissance, París, Centre de Documentation Universitaire, 1948.

GURVITCH, G.: Twentieth Century Sociology, 2 vols., G.Gurvitch y W.E. Moore (Dir.). New York. U.S.A., The Philosophical Library Inc., 1945. La Sociologie Au XX Siègle. Las grands problèmes de la sociologie, en colaboración con Wilbert E.Moore, París, Presses Universitaires de France, 1947. En España: Sociología del siglo XX, 2 tomos, trad. De la edición inglesa por C.Dimitriu y supervisión y prólogo de A.Poviña, Barcelona-Buenos Aires-Caracas-Houston-Lima-Mexico-Montevideo-Río de Janeiro, Editorial "El Ateneo", $1^{a}$ edición, 1956, $2^{a}$ ed., 1965. En el tomo I de esta obra se recoge el importante ensayo de Gurvitch sobre el "Control Social".

GURVITCH, G.: Traité de Sociologie, 2 vols., G. Gurvitch (Dir.), París, Presses Universitaires de France, 1960. Traducción castellana: Tratado de Sociología, trad. M.G. Eguibar, revisión de L.Dujovne, 2 tomos, Buenos Aires, Editorial Kapelusz, 1963 (En esta obras se contienen importantes estudios de G.Gurvitch, como "Problemas de la sociología del conocimiento", "Problemas de la sociología de la vida moral", "Problemas de la sociología del derecho", y "Notas sobre el concepto de fenómenos psíquicos totales").

GURVITCH, G.: La Vocation actuelle de la sociologie: vers une sociologie différentielle, París, Presses Universitaires de France, 1950; $2^{\mathrm{a}}$ ed., en dos volúmenes, el $1^{\mathrm{o}}$ en 1957 , el $2^{\circ}$ en $1963 ; 3^{a}$ ed., corregida y aumentada, del $1^{\text {o }}$ vol., en $1963 ; 4^{\mathrm{a}}$ ed., $1969 ; 1963$, edición revisada del Vol. II, reproducida en la $3^{\text {a }}$ ed., 1969. Traducción castellana: La Vocación actual de la sociología: Hacia una sociología diferencial, P.González Casanova, Max Aub y S. De la Fuente, México, FCE, $1^{\text {a }}$ ed., 1952: $2^{a}$ ed., 1956.

GURVITCH, G.: La sociologie de Karl Marx, Paris, Centre de Documentation Universitaire, 1959 ( $2^{\mathrm{a}}$ ed., 1961).

GURVITCH, G.: L' hyperempirisme dialectique. Ses applications en sociologie, en Cahiers Internationaux de Sociologie, vol. XV (1953), págs.3 a 33; reproducido en DUVIGNAUD, J.: Georges Gurvitch, París, éditions Seghers, 1969, págs.99 a 127.

GURVITCH, G.: "Les voies de la démocratisation industrielle”, en Esprit, juin, 1953.

GURVITCH, G.: "Les phenomènes sociaux totaux et la science de l' homme", en Esprit, 24, Mars, 1956, págs.390 a 397.

GURVITCH, G.: Déterminismes sociaux et liberté humanine. Vers l'étude sociologique des cheminements de la liberté, París, PUF, 1955; $2^{a}$ ed., París, PUF, 1963. Traducción al Idioma Portugués: Determinismos sociais e liberdade humana, Rio de Janeiro, 1968.

GURVITCH, G.: "Mon itinéraire intellectuel ou l'exclu de la horde", en Lettres Nouvelles, núm.6 (1958), págs.65 a 83. Publicado después en L' Homme et la Société, I, 
1966; y en la recopilación de DELEDALLE, G.y HUISMAN, D.: Les philosophes français d' aujourd' hui pas eux-mêmes. Autobiografhie de la philosophie française contemporaine, París, C.D.U., 1963, págs.100 a 116; igualmente recogido en DUVIGNAUD, J.: Georges Gurvitch, París, Éditions Seghers, 1969, págs.79 a 98.

GURVITCH, G.: "Les sociétés globales", en Traité de sociologie, t.I., $4^{\mathrm{a}}$ ed., París, PUF, 1962, págs. 216 y sigs.

GURVITCH, G.: Traité de sociologie, G. Gurvitch (Dir.). 2 tomos, París, PUF, $1^{\mathrm{a}}$ ed., 1958, $2^{\text {a }}$ ed., 1963, $3^{\text {a }}$ ed., 1967 (primer tomo); $1^{\text {o }}$ ed., 1960, $2^{\text {a }}$ ed., 1963, $3^{\text {a }}$ ed., 1968 (segundo tomo). Traducción Argentina: Tratado de sociología, 2 volúmenes, G. Gurvitch (Director de la obra), Buenos Aires, Kapelusz, 1962-1963. También en Buenos Aires, Depalma, 1962-1963. En España: GURVITCH, G.(Dir.): Sociología del siglo XX, 2 vols., Buenos Aires, El Ateneo, 1956 y 1957; 2ª ed., 1965.

GURVITCH, G.: "Problémes de la sociologie du droit", en GURVITCH, G.(Dir.): Traité de sociologie, t.II, París, PUF, 1ª ed., 1960, $2^{\text {a }}$ ed., 1963, 3ª ed., 1968, págs.173 a 306.

GURVITCH, G.: Le concept de classes sociales de Marx à nos jours, París, Centre de Documentation Universitaire, 1954, $2^{a}$ ed., 1958. Traducción castellana: Teoría de las clases sociales: de Marx a nuestros días, Buenos Aires, Nueva Visión, 1ª ed., 1966. También en Madrid, Cuadernos para el Diálogo (Edicusa), 1ª ed., 1971.

GURVITCH, G.: Tres capítulos de historia de la sociología: Comte, Marx y Spencer, Buenos Aires, Ediciones Galatea-Nueva Visión, 1959, 2ª ed., 1970.

GURVITCH, G.: Les fondateurs français de la sociologie contemporaine: I. Saint-Simon sociologue; II. P.J. Proudhon sociologue, París, Centre de Documentation Universitaire, 1955. Traducción castellana. Los fundadores franceses de la sociología contemporánea, Buenos Aires, Nueva Visión, s/f. Traducción Los fundadores de la sociología contemporánea, 2 vols., Prólogo e Introducción de Bernat Muniesa Brito, Barcelona, Ed. Hacer, 1984-1985. Última edición, 2001.

GURVITCH, G.: "Les phenomènes sociaux totaux et la science de 1' homme", en Esprit, 24, Mars, 1956, págs.381 a 392.

GURVITCH, G.: Les fondateurs de la sociologie contemporaine. Trois chapitres d' histoire de la sociologie. Auguste Comte, Karl Marx et Herbert Spencer, París, Centre de Domentation Universitaire, 1958. Traducción Los fundadores de la sociología contemporánea, 2 vols., Prólogo e Introducción de Bernat Muniesa Brito, Barcelona, Ed. Hacer, 1984-1985. Última edición, 2001.

GURVITCH, G.: "Deux aspects de la philosophie de Bergson: temps et liberté", en Revue de métaphisique et de morales, 1960, págs. 307 a 316.

GURVITCH, G.: La multiplicité des temps sociaux, París, Centre de Domentation Universitaire, 1958; $2^{\mathrm{a}}$ ed., 1961.

GURVITCH, G.: La sociologie de Karl Marx, París, Centre de Documentation Universitaire, 1959; $2^{\mathrm{a}}$ ed., 1961.

GURVITCH, G.: "Problèmes de sociologie du Droit", en GURVITCH, G. (Dir.): Traité de sociologie, t.II., $4^{\mathrm{a}}$ ed., París, PUF, 1962, págs.173 a 206. Estudio publicado pocos años ante de su muerte (1965).

GURVITCH, G.: "Les sociétés globales", en Traité de sociologie, t.I., $4^{\mathrm{a}}$ ed., París, PUF, 
1962, págs. 216 y sigs.

GURVITCH, G.: Dialectique et sociologie, París, Flammarion, 1962; reeditada en 1968, 1972 y 1977. Traducción al castellano: Dialéctica y Sociología, trad.J.R. Capella, Madrid, Alianza editorial, $1^{\text {a }}$ ed., 1969; $2^{\mathrm{a}}$ ed., 1971. También Venezuela, Universidad Central de Venezuela, 1965.

GURVITCH, G.: «Mon itinéraire intellectuel ou l'exclu de la horde», in Georges BALANDIER, Georges Gurvitch, sa vie, son oeuvre, Paris, PUF, 1972.

GURVITCH, G.: 'Mon itinéraire intellectuel uo l' exclu de la horde", en L' Homme et la sociéte, I, 1996, págs. 3 a 12.

GURVITCH, G.: "Mon itinéraire intellectuel ou l' exclu de la horde", en Lettres Nouvelles, núm.6 (1958), págs.65 a 83. Publicado después en L' Homme et la Société, I, 1966; en la recopilación de DELEDALLE, G. y HUISMAN, D.: Les philosophes français d'aujourd' hui pas eux-mêmes. Autobiografhie de la philosophie française contemporaine, París, C.D.U., 1963, págs.100 a 116.

GURVITCH, G.:"Pour le centenaire de la mort de P.J.Proudhon: Proudhon et Marx", París, Centre de Documentation Universitaire, 1964. También en Cahiers Internationaux de Sociologie, vol XL (1966), págs.7 a 16. Reproducido también en DUVIGNARD, J.: Georges Gurvitch, París, Éditions Seghers, 1969, págs.156 a 164. Traducción castellana: Proudhon y Marx: una confrontación, trad. De J.García Jacas, Barcelona, Oikos-Tau, 1976.

GURVITCH, G.: Proudhon, sa vie, son oeuvre, París, PUF., 1965. Traducción castellana: Proudhon. Su vida, su obra, su filosofía, trad. García Marfá, Madrid, Guadarrama, 1974.

GURVITCH, G.: Études sur les classes sociales, Paris, Denoël-Gonthier, 1966 (publicación póstuma).

GURVITCH, G.: Les cadres sociaux de la connaissance, Presses Universitaires de France, 1966 (publicación póstuma). Traducción castellana: Los marcos sociales del conocimiento, trad. de M.Giacchino, Caracas (Venezuela), Monte Avila Editores, 1969.

\section{2. Sobre Georges Gurvitch y su época}

ABAGNANO, N.: "La sociologie de la liberté: Georges Gurvitch", en Revue de métaphysique et de Morale, 1956, págs.78 a 86.

ADLER, M.: Democracia política y democracia social, trad. V. Pujolar, México D.F., Ed. Roca, 1975.

ALBERONI, F.: Movimiento e institución. Teoría general, Madrid, Editora Nacional, 1984, págs. 35 y sigs.

ALFONSO MELLADO, C., JIMENA QUESADA, L., y SALCEDO BELTRÁN, C.: La jurisprudencia del Comité Europeo de Derechos Sociales frente a la crisis económica, Albacete, Bomarzo, 2014.

ANTONOV, M.: "La théorie du droit de Georges Gurvitch et ses origins philosophiques russes", en Droit et société, núm.94 (2016/3), pages 503 à 512. https://www.cairn.info/revue-droit-et-societe-2016-3-page-503.htm. El autor subraya la 
influencia importante de la tradición jurídica Rusa y en general de pensamiento del país en el que se formó. Por ejemplo, Léon Petrazycki, Mikolai Lossky.

BERMAN, H.J.: Law and Revolution: The Formation o Western Legal Tradition, Cambridge, Harvard University Press, 1983; y su traducción al español, BERMAN, H.J.: La formación de la tradición jurídica de Occidente, trad. M. Utrilla de Neira, México D.F., FCE, 1996.

BRAUDEL, F.: "Georges Gurvitch ou la discontinuité du social", Anales, Juill.Sept., 1953, págs.347 a 361.

CARBONNIER, J.: Sociología jurídica, trad. L.Diez-Picazo, Madrid, Ed. Tecnos, 1977,

FAVRETTO, A.R.: "Dal pluralismo dei rapporti social al pluralismo delle normatività. Indiduo e Diritto in Tönnies e Gurvitch", en Sociologia del diritto, núm. 33 (1992), págs. 55 a 76.

HOOKER, B.: Legal Pluralism, Oxford, Clarendon Press-Oxford University Press, 1975.

JIMENA QUESADA, L.: Social Rights and Policies in the European Union. New challenges in a context of economic crisis, Valencia, Tirant lo Blanch, 2016.

JIMENA QUESADA, L.: "La consagración del control de convencionalidad por la Jurisdicción Constitucional en España y su impacto en materia de derechos sociolaborales (Comentario a la STC 140/2018, de 20 de diciembre)", en Revista General de Derecho del Trabajo y de la Seguridad Social, no 53 (2019), págs. 434-461.

ARNAUD, A.-J.: Entre modernidad y globalización. Siete lecciones de filosofía del Derecho y del Estado (1998), trad. N. González Lajoie, Universidad Externado de Colombia, 2000.

BALANDIER, G.: Gurvitch, París, PUF, 1972.

D’AQUANNDO, M.: Gurvitch pluralista, Napoli, Milano, Morano, 1974.

DUVIGNAUD, J.: Georges Gurvitch, París, Éditions Seghers, 1969, págs.79 a 98.

DUGUIT, L.: Las transformaciones del Derecho Público y Privado, edición crítica y estudio preliminar, "Objetivismo jurídico y teoría de los derechos en León Duguit" (pp.XI-XXXIX), a cargo de J.L. Monereo Pérez y J. Calvo González, Granada, Ed. Comares (Col. Crítica del Derecho), 2007.

DUGUIT, L.: Manual de Derecho Constitucional, edición crítica y estudio preliminar, «La teoría jurídica de León Duguit», a cargo de J.L.Monereo Pérez y J. Calvo González, Granada, Ed. Comares (Col. Crítica del Derecho), 2005.

DUGUIT, L.: Soberanía y Libertad. Lecciones dadas en la Universidad de Columbia (New York, 1920-1921), traducción y prólogo de José G. Acuña y revisión, edición y estudio preliminar a cargo de J. L. Monereo Pérez, Granada, Ed. Comares (Col. Crítica del Derecho), 2013. Esta edición culmina con un ensayo de OTTO KIRCHHEIMER, En busca de la soberanía, que apareció bajo el título "In Quest of Sovereignty", en Journal of Politics, 6 (1944).

DUGUIT, L: Le droit social, le droit individuel et la transformation de l'etat, Paris, 1927, pág.233. [Existe traducción española La transformación del Estado, trad. seguida de un estudio sobre La nueva orientación del Derecho político por Adolfo Posada, Madrid, Francisco Beltrán-Librería Española y Extranjera, s/f. (1909)]. Estas obras están integradas 
en la edición crítica, DUGUIT, L.: Las transformaciones del Derecho Público y Privado, edición crítica y estudio preliminar, “"Objetivismo jurídico y teoría de los derechos en León Duguit” (pp. XI-XXXIX), a cargo de J.L. Monereo Pérez y J. Calvo González, Granada, Ed. Comares (Col. Crítica del Derecho), 2007.

EHRLICH, E.: I fondamenti della sociologia del diritto, Milano, Giufrè, 1976.

FRIEDMAN, L.M.: "Verso una sociologia del diritto transnazionale", en Sociología del diritto, XX, 1993, 1, págs. 39 y sigs.

GÉNY, F.: Método de interpretación y fuentes en Derecho privado positivo, edición y estudio preliminar, "El pensamiento científico jurídico de Gény" (pp. XVII-LXXV), a cargo de J.L. Monereo Péerez, Granada, Ed. Comares (Col. Crítica del Derecho), 2000; GÉNY, F.: La libertad en el Derecho. Entre certeza e incertidumbre, Selección de textos e Introducción por María José Bernuz Beneitez, Granada, Ed. Comares (Col. Crítica del Derecho), 2006.

GEIGER, TH.: Estudios preliminares de sociología del Derecho, con una introducción y una bibliografía internacional a la sociología del derecho por Paul Trappe, traducción de Arturo Camacho, Guillermo Hirata y Ricardo Orozco; revisión y edición al cuidado de J.L. Monereo Pérez, Granada, Ed. Comares (Col. Crítica del Derecho), 2001.

GÉNY, F.: Método de interpretación y fuentes en Derecho privado positivo, edición y estudio preliminar, "El pensamiento científico jurídico de Gény" (pp. XVII-LXXV), a cargo de J.L. Monereo Péerez, Granada, Ed. Comares (Col. Crítica del Derecho), 2000.

HOLMES Jr, O.W.: The Common Law, trad. Fernando N. Barrancos y Vedia, revisión, edición y estudio preliminar, "La crítica iusrealista del formalismo jurídico de la cultura del "Common Law" tradicional: la concepción funcional e instrumental del Derecho de Oliver Wendell Holmes" (pp. IX-XLIX), por J.L. Monereo Pérez, Granada, Ed. Comares (Col. Crítica del Derecho), 2020.

HOLMES, O.W.: La senda del Derecho, Buenos Aires, Abeledo-Perrot, 1975.

HABERMAS, J.: Facticidad y validez. Sobre el derecho y el Estado democrático de derecho en términos de teoría del discurso, Madrid, Trotta, 1998, pág.636.

LUHMANN, N.: Poder (1979), Barcelona, Ed.Anthropos, 1995.

MONEREO PÉREZ, J.L.: La organización jurídico-económica del capitalismo moderno: El Derecho de la Economía, estudio preliminar a RIPERT, G.: Aspectos jurídicos del capitalismo moderno, trad. J. Quero Morales, revisión, edición y estudio preliminar a cargo de J. L. Monereo Pérez, Granada, Ed. Comares, (Col. Crítica del Derecho), 2001, págs. XIII-CL;

MONEREO PÉREZ, J.L.: Espacio de lo político y orden internacional. La teoría política de Carl Schmitt, Barcelona, Ediciones de Intervención Cultural/El Viejo Topo, 2015, espec., págs. 460 y sigs., y la bibliografía allí citada.;

MONEREO PÉREZ, J.L.: Soberanía y orden internacional en Carl Schmitt, estudio preliminar a SCHMITT, C.: El nomos de la tierra en el Derecho de Gentes del "Ius publicum europaeum", trad. D. Schilling Thou, revisión, edición y estudio preliminar a cargo de J.L. Monereo Pérez, Granada, Ed. Comares (Col. Crítica del Derecho), 2002, págs. XI-CXXVIII. 
MONEREO PÉREZ, J.L.: Derechos sociales de la ciudadanía y ordenamiento laboral, Madrid, Ed. Consejo Económico y Social de España, 1996, Capítulo III, sobre "una estrategia de ciudadanía basada en los derechos y en los poderes colectivos: las dos formas de concebir y extender la ciudadanía”, págs. 159 y sigs.

MONEREO PÉREZ, J.L.: La dignidad del trabajador. Dignidad de la persona en el sistema de relaciones laborales, Murcia, Laborum, 2019.

MONEREO PÉREZ, J.L.: Pluralismo jurídico y Derecho social: La sociología del Derecho de Gurvitch, Estudio Preliminar a la obra de GURVITCH, G.: Elementos de sociología jurídica, Granada, Editorial Comares (Col. Crítica del Derecho), 2001, págs. XIII-CXLVI.

MONEREO PÉREZ, J.L.: Democracia pluralista y Derecho Social. La teoría crítica de Georges Gurvitch, Barcelona, Ediciones de Intervención Cultural/El Viejo Topo, 2021.

MONEREO PÉREZ,J.L.: La democracia en crisis: Harold J. Laski, Barcelona, Ediciones de Intervención Cultural/El Viejo Topo, 2004.

MONEREO PÉREZ, J.L.: "Democracia social y económica en la metamorfosis del estado moderno: Harold J. Laski”, en Lex Social: Revista De Derechos Sociales, 11(1), 298-377 (2021). https://doi.org/10.46661/lexsocial.5426;

MONEREO PÉREZ, J.L.: La defensa del Estado Social de Derecho. La teoría política de Hermann Heller, Barcelona, Ediciones de Intervención Cultural/El Viejo Topo, 2009.

MONEREO PÉREZ, J.L.: Derechos sociales de la ciudadanía y ordenamiento laboral, Madrid, Ed. Consejo Económico y Social de España, 1996, págs. 19 y sigs.

MONEREO PÉREZ, J.L.: La reforma social en España: Adolfo Posada, Madrid, Servicio de Publicaciones del Ministerio de Trabajo y Asuntos Sociales, 2003, espec., págs. 232 y sigs. (sobre los fundamentos de la revisión de la cuestión liberal del trabajo), y págs. 356 y sigs. (respecto a la "Teoría e ideología del liberalismo social reformista");

MONEREO PÉREZ, J.L.: La protección de los derechos fundamentales. El modelo europeo, Albacete, Ed. Bomarzo, 2009, Capítulo 4, págs. 39 y sigs. (Sobre la "Constitución del Trabajo y derechos sociales de la ciudadanía", y el "Significado de las Declaraciones de Derechos Sociales: Idea social y democracia participativa. La aportación de Georges Gurvitch a la teoría de las Declaraciones de Derechos Sociales");

MONEREO PÉREZ, J.L.: “Teoría general de los derechos económicos, sociales y culturales (Artículo 22 DUDH, Preámbulo y Artículos 1 a 5 PIDECS y normas concordantes)", en MONEREO ATIENZA, C. y MONEREO PÉREZ, J.L. (Dirs.) et altri: El Sistema Universal de los Derechos Humanos. Estudio sistemático de la declaración de los derechos humanos, el pacto internacional de derechos civiles y culturales y textos internacionales concordantes, Granada, Ed. Comares, 2014, págs.445-514.

MONEREO PÉREZ, J.L.: La metamorfosis del Derecho del Trabajo, Albacete, Ed. Bomarzo, 2017.

MONEREO PÉREZ, J.L.: "La racionalización jurídica de las relaciones laborales y la emergencia de nuevas fuentes reguladoras en el orden internacional", en Lex Social. Revista Jurídica de los Derechos Sociales, vol. 8, núm.1 (2018), págs. 1 a 44.

MONEREO PÉREZ, J.L.: La democracia en crisis: Harold J. Laski, Barcelona, Ediciones de Intervención Cultural/El Viejo Topo, 2004; 
MONEREO PÉREZ, J.L.: "Democracia social y económica en la metamorfosis del estado moderno: Harold J. Laski”, en Lex Social: Revista De Derechos Sociales, 11(1), 298-377 (2021). https://doi.org/10.46661/lexsocial.5426;

MONEREO PÉREZ, J.L.: La teoría jurídica y social de Otto von Gierke: Teoría del Derecho Social y de las personas colectivas, estudio preliminar a Gierke, O.von: La función social del Derecho privado y otros estudios, Trad. José M. Navarro de Palencia, revisión y edición a cargo de J.L. Monereo Pérez, Granada, Ed. Comares (Col. Crítica del Derecho), pp. IX-LXI, 2015.

MONEREO PÉREZ, J.L: Fundamentos doctrinales del Derecho Social en España, Madrid, Editorial Trotta, 1999, espec., Cap. 1 ("Los fundamentos doctrinales del derecho social: la contribución del socialismo jurídico"), Capítulo 2 ("La influencia del socialismo jurídico en la cultura jurídica europea entre las dos guerras mundiales"), y sobre todo el capítulo 4 ("Derecho social, socialismo democrático y constitución jurídica de la clase trabajadora"; "Reforma Social y constitución del trabajo" y "La combinación de status y contrato en la constitución del trabajo").

MONEREO PÉREZ, J.L.: Fundamentos doctrinales del Derecho social en España, Madrid, Trotta, 1996.; MONEREO PÉREZ, J.L.: "El pensamiento jurídico-social de Fernando de los Ríos y su Generación", en CÁMARA, G. (ed.): Fernando de los Ríos y su tiempo, Granada (Universidad), 2000, págs.85 y sigs.

MONEREO PÉREZ, J.L.: La reforma social en España: Adolfo Posada, Madrid, Servicio de Publicaciones del Minsiterio de Trabajo y Asuntos Sociales, 2003, 515 páginas, espec., Capítulo II ("Crisis del Estado de Derecho Liberal y Reforma Constitucional: El reformismo social como alternativa a la crisis del Estado de Derecho Liberal”), págs. 133 y sigs. MONEREO PÉREZ, J.L.: Sindicalismo reformista integrado y Estado democrático en el republicanismo social de Adolfo Posada, estudio preliminar a POSADA, A.: Teoría social y jurídica del Estado. El Sindicalismo (1922), edición y estudio preliminar a cargo de J.L. Monereo Pérez, Granada, Ed. Comares (Col. Crítica del Derecho), 2018, págs. IX-LXIX.

MONEREO PÉREZ, J.LL: Derechos sociales de la ciudadanía y ordenamiento laboral, Madrid, Ed. Consejo Económico y Social de España, 1996, págs. 159 y sigs.

MONEREO PÉREZ, J.L.: La garantía de los derechos de seguridad social en la Carta Social Europea en tiempos de crisis, Murcia, Laborum, 2021.

MONEREO PÉREZ, J.L.: Pluralismo jurídico y Derecho social: La sociología del Derecho de Gurvitch, Estudio Preliminar a la obra de GURVITCH, G.: Elementos de sociología jurídica, Granada, Editorial Comares (Col. Crítica del Derecho), 2001, págs.13-146;

MONEREO PÉREZ, J.L.: Democracia pluralista y Derecho Social. La teoría crítica de Georges Gurvitch, Barcelona, Ediciones de Intervención Cultural/El Viejo Topo, 2021.

MONEREO PÉREZ, J.L.: La protección de los derechos fundamentales. El Modelo Europeo, Albacete, Ed. Bomarzo, 2009, contiene un capítulo expresamente dedicado a la aportación de Georges Gurvitch a las Declaraciones y Textos Internacionales aprobados a partir de la Segunda Postguerra Mundial dentro del sistema internacional de garantía de los derechos fundamentales.

MONEREO ATIENZA, C. y MONEREO PÉREZ, J.L. (Dirs. y Coords.): El Sistema Universal de los Derechos Humanos. Estudio Sistemático de la declaración de los 
derechos humanos, el pacto internacional de derechos civiles y políticos, el pacto internacional de derechos económicos, sociales y culturales y textos internacionales concordantes, Granada, Ed. Comares, 2014, 1043 págs.

MONEREO PÉREZ, J.L.: "Carta comunitaria de los derechos fundamentales de los trabajadores" (I y II), en Civitas. Revista Española de Derecho del Trabajo, núm.56-57 (I/1992-II/1993), núm. 56, págs. 844-898, y núm. 57, págs. 61-90.

MONEREO PÉREZ, J.L.: Modernización y racionalización del poder y del Derecho. La crítica de la razón instrumental en Max Weber, estudio preliminar a WEBER, M.: Política y Ciencia y otros ensayos de sociología, trad. C. Correas, revisión, edición y estudio preliminar a cargo de J.L. Monereo Pérez, Granada, Ed. Comares (Col. Crítica del Derecho), 2013, págs. IX-LXII;

MONEREO PÉREZ, J.L.: Modernidad y Capitalismo. Max Weber y los dilemas de la Teoría Política y Jurídica, Barcelona, Ediciones de Intervención Cultural/El Viejo Topo, 2013.

MONEREO PÉREZ, J.L.: Cuestión social y reforma moral: las 'corporaciones profesionales' en Durkheim, estudio preliminar a DURKHEIM, E.: Lecciones de sociología. Física de las costumbres y del Derecho, trad. Estela Canto, revisión, edición y estudio preliminar a cargo de J.L. Monereo Pérez, Granada, Ed. Comares (Col. Crítica del Derecho), 2006, págs. VII-LI.;

MONEREO PÉREZ, J.L.: Razones para actuar: solidaridad orgánica, anomia y cohesión social en el pensamiento de Durkheim, estudio preliminar a DURKHEIM, D.: Sociología y Filosofía, trad. J. M. Bolaño (hijo), revisión, edición, y estudio preliminar a cargo de J. L. Monereo Pérez, Granada, Ed. Comares (Col. Crítica del Derecho), 2006, págs. VII-LXVI.

MONEREO ATIENZA, C. y MONEREO PÉREZ, J.L. (Dirs. y Coords.): La Europa de los Derechos. Estudio Sistemático de la Carta de los Derechos Fundamentales de la Unión Europea, Granada, Ed.Comares, 2012, espec., estudio de MONEREO PÉREZ, J.L. del "Título VII. Disposiciones que rigen la interpretaicón y la aplicación de la Carta, artículos 51-54”, págs. 1299- 1444.

MONEREO ATIENZA, C. Y MONEREO PÉREZ, J.L. (Dirs. y Coords.): La garantía multinivel de los derechos fundamentales en el Consejo de Europa. El Convenio Europeo de los Derechos Humanos y la Carta Social Europa, Granada, ed. Comares, 2017, Parte II (“Carta Social Europea”), págs. 357-1005,

NIETO CÁNOVAS, C.: Georges Gurvitch: de la filosofía a la sociología del conocimiento, Alicante, Institut de Cultura "Juan Gil-Albert", 1995, passim.

POUND, R.: "Sociología y jurisprudencia”, en GURVITCH, G.y MOORE, W.E. (Dir.): Sociología del siglo XX, t.I., Barcelona, Ed. El Ateneo, 1970, págs.271 y sigs.

POUND, R.: Las grandes tendencias del pensamiento jurídico, traducción y estudio preliminar (pp. IX-XXXVIII) por José Puig Brutau, revisión y edición al cuidado de J. L. Monereo Pérez, Granada, Comares (Col. Crítica del Derecho), 2004.

POUND, R.: Evolución de la libertad. El desarrollo de las garantías constitucionales de la libertad, edición y estudio preliminar, "La "jurisprudencia sociológica" de Roscoe Pound: la teoría del derecho como ingeniería social" (pp. IX-LXXXIII), a cargo de J. L. Monereo Pérez, Granada, Ed.Comares (Col. Crítica del Derecho), 2004. 
RADBRUCH, G.: "Del derecho individualista al derecho social", en RADBRUCH, G.: El Hombre en el Derecho. Conferencias y artículos seleccionados sobre cuestiones fundamentales del Derecho, trad. Aníbal del Campo, revisión, edición y estudio preliminar a cargo de J.L. Monereo Pérez, Granada, Comares (Col. Crítica del Derecho), 2020.

RENARD, G.: Sindicatos, Trade-Unions y Corporaciones, trad. M. Nuñez de Arenas, revisión, edición y estudio preliminar, "El sindicato y el orden democrático" (pp.VIICVII), a cargo de J.L. Monereo Pérez, Granada, Ed. Comares (Col. Crítica del Derecho), 2014. RÍOS, F. DE: El sentido humanista del socialismo, Javier Morata Ed., Madrid, 1926 (reed. Edit. Castalia, Madrid, 1976.

RIPERT, G.: Aspectos jurídicos del capitalismo moderno, trad. J. Quero Morales, edición y estudio preliminar, "La organización jurídico-económica del capitalismo: El Derecho de la Economía” (pp. XIII-CL), a cargo de J.L. Monereo Pérez, Granada, Ed. Comares (Col. Crítica del Derecho), 2000.

ROSS, A.: Lógica de las normas, trad. S.-Hierro, revisión, edición y estudio preliminar, "Alf Ross, la ambición de la teoría realista del Derecho" (pp. XI-CXXXVI), a cargo de J.L. Monereo Pérez, Granada, Ed. Comares (Col. Crítica del Derecho), 2000.

ROSS, A.: Teoría de las fuentes del Derecho, Estudio preliminar de Muñoz de Baena Simón y otros, Madrid, CEPC, 1999.

ROSS, A.: Hacia una ciencia realista del Derecho, trad. J. Barboza, Buenos Aires, Abeledo-Perrot, 1961.

ROSS, A.: Sobre el Derecho y la justicia, trad. G. R. Carrió, Buenos Aires, Eudeba, 1963.

POUND, R.: La Evolución de la Libertad. El desarrollo de las garantías constitucionales de la libertad, edición y estudio preliminar, "La 'jurisprudencia sociológica' de Roscoe Pound: La teoría del Derecho como ingeniería social” (pp. IX-LXXXIII), a cargo de J.L. Monereo Pérez, Granada, Ed. Comares (Col. Crítica del Derecho), 2004.

SIMMEL, G.: Filosofía del Dinero, traducción e Introducción de Ramón García Cotarelo, edición al cuidado de J.L. Monereo Pérez, Granada, Ed. Comares (Col. Crítica del Derecho), 2003;

SOUSA SANTOS, B.D.: Sociología crítica. Para un nuevo sentido común en el derecho, Nota introductoria y revisión de la traducción de Carlos Lema Añon, Madrid, Ed. Trotta, 2009, espec., págs. 52 y sigs.

TEUBNER, G.: Le droit, un système autopoïétique, París, PUF, 1993.

TÖNNIES, F.: Comunidad y asociación, trad. José-Francisco Ivars, revisión técnica de J.L. Monereo Pérez, edición y estudio preliminar, "La interpretación de la Modernidad en Tönnies: "Comunidad" y "Sociedad-Asociación” en el desarrollo histórico" (pp. XIXLIV), a cargo de J. L. Monereo Pérez, Granada, Ed. Comares (Col. Crítica del Derecho), 2009, págs. 9 y sigs.

TÖNNIES, F.: Principios de sociología, trad. Vicente Lloréns, revisión, edición y estudio preliminar, "La sociología como crítica social: la aportación de Ferdinand Tönnies" (pp. XV-XLVI), a cargo de J.L. Monereo Pérez, Granada, Ed. Comares (Col. Crítica del Derecho), Granada, 2009.

TANZI, A.: Georges Gurvitch e il progetto della libertà, Pisa, Pacini, 1980, 
TREVES, R.: La sociología del Derecho. Orígenes, investigaciones, problemas, trad.M.Atienza, Mª J.Añon Roig y J.A.Pérez Lledó, Madrid, Ariel, 1988,

TOULEMONT, R.: Sociologie et pluralisme dialectique. Introduction à l'oeuvre de Georges Gurvitch, Louvain-París, ed. Nauwelaerts, 1955,

LÉVY-BRUHL, H.: Sociologie du droit, París, PUF, 1964 (Sociologia do direito [1961], Sao Paulo, Livraria Martins Fontes Editora Ltda, $2^{\circ}$ ed., 1997).

BOBBIO,N.: "Gurvitch y los derechos sociales", en El tiempo de los derechos, Madrid, Ed.Sistema, 1991, págs.27 y sigs.

SUNSTEIN,C.R.: "Constituciones y democracia: Epílogo", en ELSTER,J.y SLAGSTAD,R.: Constitucionalismo y democracia, México, FCE, 1999, págs.344 y sigs.

PRZEWORSKI, A.: Qué esperar de la democracia. Los límites y posibilidades del autogobierno, trad. S. Mastrangelo, Buenos Aires, Siglo Veintiuno Editories, 2010,

SCHWEICHKART, D.: Más allá del capitalismo (1993), trad. C. Escriche Blancafort, Prólogo de Luis de Sebastián, Santander-Editorial Sal Terrae, Barcelona-Cristianisme i Justícia, 1997, págs. 133 y sigs., 263 y sigs. y 395 y sigs.

GIERKE, O.VON.: La función social del Drecho privado y otros estudios, trad. J.M. Navarro de Palencia, Revisión, edición y estudio preliminar, "La teoría jurídica y social de Otto von Gierke: Teoría del Derecho Social y de las personas colectivas" (pp. IX-LXI), a cargo de J.L. Monereo Pérez, Granada, Ed. Comares (Col. Crítica del Derecho), 2015.

HIRST, P.: From Statism to Pluralism, Democracy, Civil Society and Global Politics ("Del estatismo al pluralismo. Ensayos sobre la democracia asociativa"), Londres, UCL, Press-Taylor \& Francis, 1997, Capítulos 3 y 4.

FERRERO, G.: El poder. Los genios invisibles de la ciudad, Madrid, Ed. Tecnos, 1998.

FOUCAULT, M.: Microfísica del poder, trad. Horacio Pons, Buenos Aires, Siglo Veintiuno Editores Argentina, 2019.

STAFANI, M.A.: G. Gurvitch sociologo del diritto, Assisi-Roma, Carucci, 1974;

SINZHEIMER, H.: «Der Wandel im Weltbild des Juristen» («El cambio en la concepción del mundo del jurista»), en Zeits $\neg$ chrift für soziales Recht, año 1 (1928), págs. 2 a 6;

SINZHEIMER, H.: “Die Idee des Arbeitsrechts”, ArbR, 1923, pp. 721-730 y

SINZHEIMER, H.: "Der Kampf um das neue Arbeitsrecht" (1923), en OTTO KAHNFREUND Y THILO RAMM (ed.): Hugo Sinzheimer. Arbeitsrecht und Rechtssoziologie. Gesammelte Aufsätze und Reden, Europäische Verlagsanstalt, Frankfurt am Main y Köln, 1976, págs. 91-99;

SINZHEIMER, H.: «El problema del hombre en el Derecho», en SINZHEIMER, H.: Crisis económica y derecho del trabajo. Cinco estudios sobre la problemática humana y conceptual del Derecho del Trabajo, trad. F. Vázquez Mateo, Madrid, MTSS, 1984, págs. $110 \mathrm{y}$ sigs.

TREVES, R.: "Sociologia del diritto oggi e crisis dello Stato sociale", en Sociologia del diritto, núms.2-3 (1986), págs.247 y sigs.

TOULEMONT, R.: Sociologie et pluralisme dialectique. Introduction à l'oeuvre de Georges Gurvitch, Louvain-París, ed.Nauwelaerts, 1955; 
TANZI, A.: Georges Gurvitch. Il progetto della libertà, Pisa, Pacini, 1980, especialmente el capítulo I.

TANZI, A.: Democrazia e Sistema pluralista in G. Gurvitch, Siena, Circolo Giuridico dell' Università, 1974;

SAINT-SIMON, C.H.DE.: La physiologie sociale, ed. a cargo de G.Gurvitch, con Introducción y Notas suyas, París, PUF, 1965.

LE BON, G.: Psicología de las multitudes, trad. J.M. Navarro de Palencia, revisión de J.L. Monereo Pérez, edición y estudio preliminar, "La Era de las masas: El pensamiento socio-político de Gustave Le Bon" (pp. XIII-LXXVII), a cargo de J.L. Monereo Pérez, Granada, Ed. Comares (Col. Crítica del Derecho), 2012; y

SOREL, G.: Reflexiones sobre la violencia, Versión castellana por Augusto Vivero, revisión técnica, edición y estudio preliminar "Teoría e ideología del sindicalismo en Georges Sorel” (pp. XI-LXIV), a cargo de J.L. Monereo Pérez, Granada, Ed. Comares (Col. Crítica del Derecho), 2011.

GIDDENS, A.: La estructura de clases en las sociedades avanzadas, Madrid, Alianza, 1993; WRIGHT, E.O.: Clases, Madrid, Siglo XXI, 1994;

CROMPTON, R.: Clases y estratificación, Madrid, Tecnos, 1994;

REISSMAN, L.: "Estratificación social", en SMELSER, N.J.: Sociología, Madrid, Euramerica, 1974, págs. 269 y sigs.

LASKI, H.J.: "La conception de l' État de Léon Duguit", en Archives de philosophie du droit et de sociologie jurídique, núm. 1-2 (1932).

ROSELLI, C.: Socialismo liberale (1930), Torino, Einaudi, 1979.

RITZER, G.: Teoría sociológica moderna, trad. M. T. Casado Rodríguez, revisión de M. Requesa, Madrid, Ed. McGraw-Hill/Interamericana de España, 2002.

MACPHERSON, C.B.: Ascenso y caida de la justicia económica y otros ensayos (1985), cap.8 ("Pluralismo, individualismo y participación"), Buenos Aires, Eds. Manantial, 1991.

MARCUSE, H.: El hombre unidimensional, Barcelona, Seix Barral, 1964). MENGER, A.: El Derecho Civil y los Pobres, trad. Adolfo Posada, revisión, edición crítica y estudio preliminar, "Reformismo social y socialismo jurídico: Antón Menger y el socialismo jurídico en España” (pp. 7-114), a cargo de J.L. Monereo Pérez, Granada, Ed. Comares (Col. Crítica del Derecho), 1998.

MONEREO PÉREZ, J.L.: La defensa del Estado Social de Derecho. La teoría política de Hermann Heller, Barcelona, Ediciones de Intervención Cultural/El Viejo Topo, 2009;

LASKI, H.J.: A Grammar of Politics (1925), London, Allen and Unwin. Trad.esp., T. González García, La Gramática de la Política. El Estado moderno, revisión técnica, edición crítica y estudio preliminar, "La filosofía política de Harold J. Laski (pp. XVCXVIII)", a cargo J.L. Monereo Pérez, Granada, Comares (Col. Crítica del Derecho), 2002;

MONEREO PÉREZ, J.L.: La democracia en crisis: Harold J.Laski, Barcelona, Ediciones de Intervención Cultural/El Viejo Topo, 2004;

MONEREO PÉREZ, J.L.: La crisis de la socialdemocracia europea. Eduard Bernstein y la premisas del socialismo reformista, Barcelona, Ediciones de Intervención Cultural/El 
Viejo Topo, 2012.

MONEREO PÉREZ, J.L.: La democracia en crisis: Harold J. Laski, Barcelona, Ediciones de Intervención Cultural/El Viejo Topo, 2004, págs. 7 y sigs., y 37 y sigs.

MONEREO PÉREZ, J.L.: Reformismo social y socialismo jurídico: Antón Menger y el socialismo jurídico en España, estudio preliminar a MENGER, A.: El Derecho Civil y los Pobres, trad. Adolfo Posada, revisión, edición crítica y estudio preliminar, a cargo de J.L. Monereo Pérez, Granada, Ed. Comares (Col. Crítica del Derecho), 1998, págs.7-114; MONEREO PÉREZ, J.L.: Pluralismo jurídico y Derecho social: La sociología del Derecho de Gurvitch, Estudio Preliminar a la obra de GURVITCH, G.: Elementos de sociología jurídica, edición de J.L. Monereo Pérez, Granada, Editorial Comares (Col. Crítica del Derecho), 2001, págs. XIII-CXLVI.

MENGONI, L.: "L' Europa dei codici o un codice per l' Europa?", en RCDP, núm.4 (1992), págs.515 y sigs., en particular pág.515.

ZAGREBELSCKY, G.: El derecho dúctil, Madrid, Trotta, 1995.

O'DONNELL, G. y SCHMITTER, P. y WHITEHEAD, L. (eds.): Transitions form Authoritarian Rule, 4 vols., Baltimore, The John Hopkins University Press, 1986.

KERCHOVE, M.V. DE y OST, F.: El sistema jurídico entre orden y desorden, Madrid, Servicio de Publicaciones de la Facultad de Derecho de la UCM, 1997.

KORSCH, K.: Luchas de clases y Derecho del Trabajo (1922), Barcelona, Ed. Ariel, 1980, passim; KORSCH, K.: ¿Qué es socialización?, Introducción de E. Gerlach, trad. J. Muñoz. Barcelona, Ed. Ariel, 1975.

SINZHEIMER, H.: Ein Arbeitstarifgesetz. Die Idee der sozialen Selbstbestimmung im Recht, 1916, pág.186.; Ibid., "La théorie des sources du droit et le droit ouvrier", en Annuaire de l'Institut International de Philosophie du Droit et de Sociologie Juridique, 1934, págs.73 y sigs.

RIPERT, G.: Les forces créatrices du droit, Paris, L.G.D.J., 1955, págs.249 y sigs.

HELD, D.: La democracia y el orden global. Del Estado moderno al gobierno cosmopolita, Barcelona, Paidós, 1997.

DEZALAY, Y.: Marchands de droit. La restructuration de l'ordre juridique international par les multinationales du droit, París, Fayard, 1992;

KYMLICKA, W.: Ciudadanía multicultural. Una teoría liberal de los derechos de las minorías, Barcelona, Ed. Paidós, 1996,

TEUBNER, G.: Le droit, un système autopoïétique, París, PUF, 1993.

SAlCEDO BELTRÁN, C. (Dir.): La Carta Social Europea. Pilar de recuperación y sostenibilidad del modelo social europeo. Homenaje al Profesor José Vida Soria, Valencia, Tirant lo Blanch, 2021.

WEBER, M.: Sociología del Derecho, que incluye también la "Sociología del Poder", edición y estudio preliminar, a cargo de J.L. Monereo Pérez, Granada, Ed. Comares (Col. Crítica del Derecho), 2001.

WEBER, M.: Economía y sociedad, trad. de J. Medina Echavarría y otros, México, Ed. FCE, 1983. 
WEITZMAN, M.L.: La economía de participación, trad. E. L. Suárez, Madrid, FCE, 1987, págs. 9 y sigs.

WIEACKER,F.: Historia del Derecho Privado de la Edad Moderna, edición al cuidado de J.L. Monereo Pérez, Granada, Ed.Comares (Col. Crítica del Derecho), 2000, Quinta Parte.

WRIGHT MILLS, C.: La imaginación sociológica (1959), trad. F. M. Torner, Prólogo de Gino Germani, México D.F., Ed. FCE, 1986. .

WRIGHT MILLS, C.: La élite del poder, México, F.C.E., 1956.

FEBBRAJO, A.: "E. Ehrlich: Dal diritto libero al diritto vivente", en Sociologie del diritto, núm.3 (1982), págs.137 y sigs.; FEBBRAJO, A.: "Regolazione giuridica e autoregolazione sociale", en Sociologia del diritto, núms.2-3 (1986), págs.145 y

PREUSS, U.K.: Revolution, Fortschritt und Verfassung, Berlin, 1990, pág.73.

BRUNI, L. (Coord.): Economía de Comunión. Por una Cultura económica centrada en la persona, Madrid, Ed. Ciudad Nueva, 2001,

POLANYI, K.: Nuestra obsoleta mentalidad de mercado, en POLANYI, K.: La esencia del fascismo. Seguido de Nuestra obsoleta mentalidad de mercado, edición, traducción y estudio introductorio de C. Ruiz Sanjuán, Madrid, Escolar y Mayo Editores, 2013, págs. 83 y sigs.

POSADA, A.: La nouvelle Constitution espagnole, París, 1932.

POSADA, A.: Teoría social y jurídica del Estado. El Sindicalismo (1922), edición y estudio preliminar a cargo de J.L. Monereo Pérez, Granada, Ed. Comares (Col. Crítica del Derecho), 2018. 